\title{
Factors affecting the fetal hemoglobin levels in patients with sickle cell anemia and thalassemia
}

Citation for published version (APA):

Dimovski, A. J. (1993). Factors affecting the fetal hemoglobin levels in patients with sickle cell anemia and thalassemia. [Doctoral Thesis, Maastricht University]. Rijksuniversiteit Limburg. https://doi.org/10.26481/dis.19931125ad

Document status and date:

Published: 01/01/1993

DOI:

10.26481/dis.19931125ad

Document Version:

Publisher's PDF, also known as Version of record

\section{Please check the document version of this publication:}

- A submitted manuscript is the version of the article upon submission and before peer-review. There can be important differences between the submitted version and the official published version of record.

People interested in the research are advised to contact the author for the final version of the publication, or visit the DOI to the publisher's website.

- The final author version and the galley proof are versions of the publication after peer review.

- The final published version features the final layout of the paper including the volume, issue and page numbers.

Link to publication

\footnotetext{
General rights rights.

- You may freely distribute the URL identifying the publication in the public portal. please follow below link for the End User Agreement:

www.umlib.nl/taverne-license

Take down policy

If you believe that this document breaches copyright please contact us at:

repository@maastrichtuniversity.nl

providing details and we will investigate your claim.
}

Copyright and moral rights for the publications made accessible in the public portal are retained by the authors and/or other copyright owners and it is a condition of accessing publications that users recognise and abide by the legal requirements associated with these

- Users may download and print one copy of any publication from the public portal for the purpose of private study or research.

- You may not further distribute the material or use it for any profit-making activity or commercial gain

If the publication is distributed under the terms of Article $25 \mathrm{fa}$ of the Dutch Copyright Act, indicated by the "Taverne" license above, 


\section{FACTORS AFFECTING THE FETAL HEMOGLOBIN LEVELS IN PATIENTS}

WITH SICKLE CELL ANEMIA AND THALASSEMIA

ALEKSANDAR JOVO DIMOVSKI 



\title{
FACTORS AFFECTING THE FETAL HEMOGLOBIN LEVELS IN PATIENTS WITH SICKLE CELL ANEMIA AND THALASSEMIA
}

\section{PROEFSCHRIFT}

\author{
ter verkrijging van de graad van doctor \\ aan de Rijksuniversiteit Limburg te Maastricht, \\ op gezag van de Rector Magnificus, Prof. Mr. M.J. Cohen, \\ volgens het besluit van het College van Dekanen, \\ in het openbaar te verdedigen \\ op donderdag 25 november 1993 om 14.00 uur
}

door

\author{
ALEKSANDAR JOVO DIMOVSKI \\ geboren te Skopje, Macedonië \\ in 1962
}




\section{Promotores:}

Prof. Dr. P.J. Brombacher

Prof. Dr. T.H.J. Huisman, University of Georgia, USA

\section{Beoordellngscommissle:}

Prof. Dr. J.P.M. Geraedts, voorzitter

Prof. Dr. J.W. Arends

Prof. Dr. L.F. Bernini, Rijksuniversiteit Leiden

Prof. Dr. Georgi D. Efremov, Macedonian Academy of Sciences and Arts, Research Center for New Technologies, Skopje, Republic of Macedonia.

Prof. Dr. H.C. Hemker 


\section{ACKNOMLEDGEMENTS}

I would like to express my deepest gratitude to Professor Dr. P.J. Brombacher for his support in the realization of this dissertation. The work presented here could not have been accomplished without the generous help and guidance of Professor Dr. T.H.J. Huisman for whom I reserve my special thanks. I use this opportunity to also thank Professor Dr. G.D. Efremov for his continuous support and encouragement from the very beginning of my work in the field of hemoglobinopathies. I am very grateful to Mrs. Marianne F. Carver for the superb editorial and technical assistance during the preparation of the dissertation. I would also like to thank Dr. A.D. Adekile for the helpful discussions and critical comments on the manuscript. And last, but not least, it is a pleasure to acknowledge the numerous colleagues who have contributed either by providing the blood samples or by taking part in the experiments presented in this dissertation. To all of them I express my deepest thanks. 


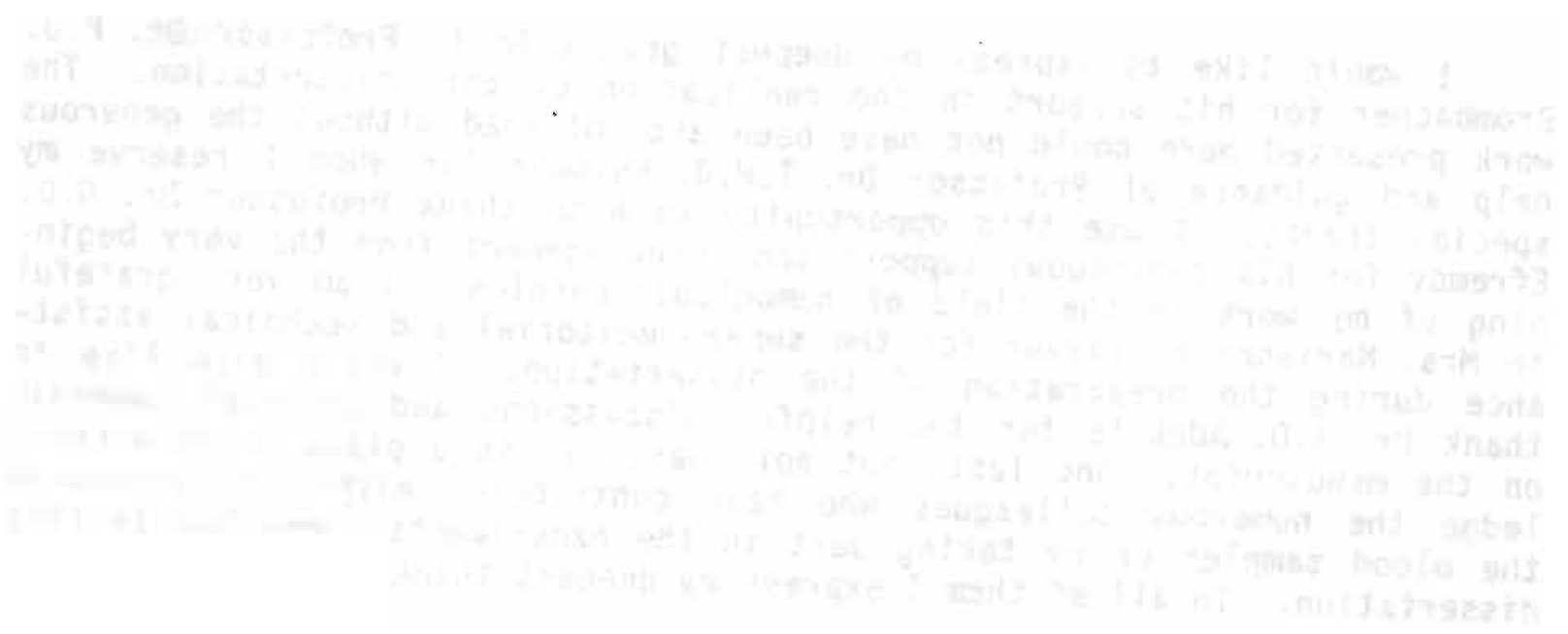


Valentina, Dora and Nena 


\section{CONIENTS}

Abbreviations

$3 a$ Sequence Variations in the 5' Flanking and IVS-II Regions of the $G_{\gamma}$ and $A_{Y-G l o b i n}$ Genes of ${ }_{\beta} S$ Chromosoines With Five Different Haplotypes

3b Certain Mutations Observed in the $5^{\prime}$ Sequences of the $G_{\gamma}$ - and $A_{Y-G l o b i n}$ Genes of ${ }_{B} S$ Chromosomes are Specific for Chromosomes With Major Haplotypes

$3 c \quad{ }_{B} S$ Haplotypes in Various Horld Populations

3d Sequence Variations in the $5^{\prime}$ Hypersensitive Site-2 of the Locus Control Region of ${ }_{B} \mathbf{S}$ Chromosomes are Associated With Different Levels of Fetal Globin in Hemoglobin S Homozygotes

3e Haplotype-Specific Sequence Variations in the Locus Control Region (5' Hypersensitive Sites 2, 3, 4) of is Chromosomes

4 B Black B-Thalassemia Homozygotes With Specific Sequence Yariations in the $5^{\prime}$ Hypersensitive Site-2 of the Locus Control Region Have High Levels of Fetal Hemoglobin

4b A $B^{\circ}$-Thalassemia Due to a 1605 bp Deletion of the $B$ Globin Gene Region

4c A Novel Deletion of $227 \mathrm{~Kb}$ Including the $\beta-610 b i n$ Gene and the LCR 3'HS-1 Regulatory Sequence: $B^{\circ}$-Thalassemia or HPFH?

4d Polymorphic Pattern of the (AT) X(T)y Motif at $-5305^{\prime}$ to the $B-61$ obin Gene in Over 40 Patients Homozygous for Various B-Thalassemia Mutations

4e The In Vivo Expression of the Globin Genes of the $B$ Cistron in $\gamma^{-}, \delta_{-}$, and $\delta \beta-T h a l a s s e m i a$ Heterozygotes

Discussion

Sumary

Samenvatting 


\section{ABBREVIATIONS}

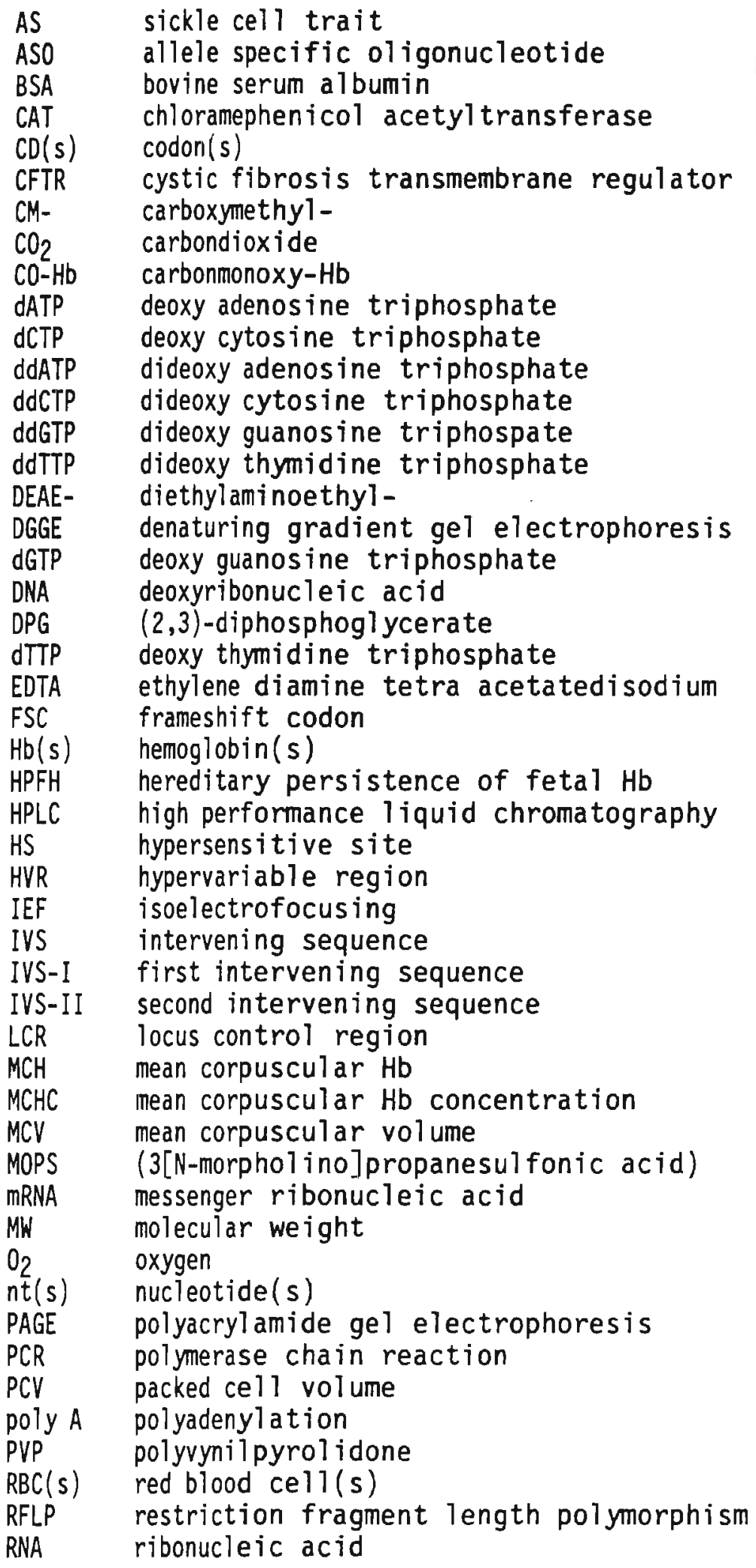


sodium dodecilsulphate

Southeast Asian

SS sickle cell anemia

SSC sodium saline citrate buffer

SSPE

TMAC sodium saline phosphate EDTA buffer

TBE tetramethyl armonium chloride

TE Tris borate EDTA buffer

TEA

TFA thal UTR Tris EDTA buffer Tris EDTA acetate buffer trifluoroacetic acid thalassemia untranslated region 
CHAPTER 1

$$
\text { I N T RODUCTION }
$$

$$
\text { A N D }
$$

REVIEN OF THE LITERATURE 



\section{CHAPTER 1}

\section{INTRODUCTION}

The hemoglobinopathies are a heterogeneous group of inherited disorders which are characterized by qualitative (abnormal Hbs) or quantitative (thalassemias) changes in $\mathrm{Hb}$ synthesis. They are one of the most common monogenic diseases, creating major public health problems in many, mainly underdeveloped, countries all over the world. Therefore, the studies of the etiology, genetics, pathophysiology, and therapy of these diseases has attracted major interest during the past 50 years.

The abundance of $\mathrm{Hb}$ in the red cells, the relative ease of its extraction, and a large number of naturally occurring variants, has made $\mathrm{Hb}$ a model protein for the study of primary, secondary, and tertiary structures of proteins in general. Moreover, hemoglobinopathies have served as a natural model for studies dealing with principles of molecular bases of genetic diseases and developmental tissue-specific gene expression in mammalian cells.

The advances of molecular biological techniques have made it possible to determine the molecular basis of various forms of hemoglobinopathies and to initiate prenatal diagnosis prevention programs in many countries. However, the therapy of the patients with these disease is still not satisfactory.

In the last decade a general interest has developed into the understanding of the molecular and cellular mechanisms involved in the developmental regulation of the globin genes. The finding that elevated levels of fetal $H b$ ( $H b F$ ) in patients with SS and thalassemia has ameliorating effects on the clinical course of these diseases, has provided a new perspective for their therapy. Unfortunately, the factors that are involved in the normal transition from fetal to adult $\mathrm{Hb}$ synthesis, as well as the variation of the levels of $\mathrm{Hb} \mathrm{F}$ in patients with $\mathrm{SS}$ and thalassemia are still poorly understood.

From the data that have been accumulated thus far, it has become evident that the levels of $\mathrm{Hb} \mathrm{F}$ in these patients are influenced by several factors which are either linked to the B-globin gene cluster, or are regulated by genes located on other chromosomes. The $\beta$-globin gene haplotypes serve as markers for some of the genetic factor(s) which contribute to the determination of the levels of $\mathrm{Hb} F$ because a definitive linkage has been established. However, the sequence differences specific for each haplotype, which could account for the variable $H b$ expression under the hematopoietic stress in these diseases, have not been determined. Therefore, the main objective of the studies reported in this dissertation is:

To determine the sequence variations in the regulatory regions of the $\beta-g l o b i n g e n e ~ c l u s t e r$ for various chromosomes which carry the ${ }_{\beta} S$ and/or $\beta$-thal mutations, and to evaluate their influence on the in vivo expression of $H b F$ among $S S$ and $\beta$-thal patients from various populations. 


\section{HB F IN SICKLE CELL ANEMIA AND B-THALASSEMIA: A REVIEH}

1. Structure and Function of Human Hbs. Human Hbs are heterogeneous tetrameric metalloproteins made up of two asymmetric dimers and four heme groups (reviewed in Ref. 1). In normal adults the major component, comprising about $97 \%$ of the total $\mathrm{Hb}$, is $\mathrm{Hb} \mathrm{A}$. A minor fraction accounting for about 2-3\% is called $\mathrm{Hb} \mathrm{A}$, first described by Kunkel and Wallenius in 1955 (2). The main $\mathrm{Hb}$ in fetal life is fetal $\mathrm{Hb}$ or $\mathrm{Hb} F$; traces of this protein are found in a small population of cells in normal adults. This is preceded in early fetal life by the embryonic Hbs Gower-I and Gower-II, and Hbs Portland-I, Portland-II, and Portland-III (3-5).

Human Hbs are tetramers with a MW of about 64,000. Adult and fetal $\mathrm{Hb}$ have a chains associated with $B\left(\mathrm{Hb} A, \alpha_{2}{ }_{2}\right), \delta\left(H b A_{2}, \alpha_{2} \delta_{2}\right)$ or $\gamma$ chains ( $\left.H b F, \alpha_{2} \gamma_{2}\right)$, whereas in the embryo $\zeta$ chains combine with $Y$ (Hb Portland-I, $\left.\zeta_{2} \mathrm{~V}_{2}\right), \beta$ (Hb Portland-II, $\left.\zeta_{2} \beta_{2}\right), \delta\left(H b\right.$ Portland-III, $\zeta_{2} \delta_{2}$ ) or $\varepsilon$ (Hb Gower-I,

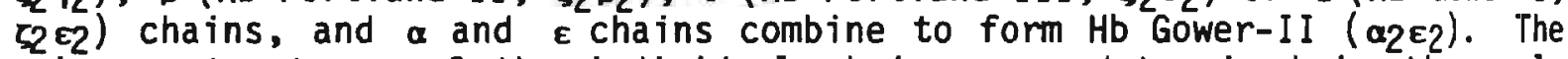
primary structures of the individual chains were determined in the early 1960s (6-8), while the secondary, tertiary, and quaternary structures were determined in subsequent years by Perutz and his collaborators (reviewed in Ref. 9).

The major function of $\mathrm{Hb}$ is to transport $\mathrm{O}_{2}$ from the lungs to the tissues. The efficiency of this transport can be determined by measuring the $\mathrm{O}_{2}$ affinity curve and its $\mathrm{P}_{50}$ value (normal value at $\mathrm{pH} 7.4$ and $37^{\circ} \mathrm{C}$ is $26 \mathrm{~mm} \mathrm{Hg}$ ) (10). A normal $\mathrm{O}_{2}$ affinity curve is sigmoid-shaped because $\mathrm{Hb}$ is an allosteric protein and shows cooperative $\mathrm{O}_{2}$ binding; the binding of each $\mathrm{O}_{2}$ molecule promotes the binding of additional molecules. An increase in the amount of $\mathrm{CO}_{2}$ in blood reduces the affinity of $\mathrm{Hb}$ for $\mathrm{O}_{2}$; this so-called Bohr effect has great physiological significance because the $\mathrm{CO}_{2}$ exchange and the resulting $\mathrm{pH}$ change facilitate $\mathrm{O}_{2}$ binding at the lungs and $\mathrm{O}_{2}$ unloading in the tissues (11). 2,3-DPG is a major organic phosphate present in red cells in a concentration of 4-5 $\mathrm{mM}$ which corresponds to the concentration of intracellular $\mathrm{Hb}$. One molecule of 2,3-DPG binds to one molecule of deoxy-Hb (binding sites: Val 1, His 2, Lys 82 , and $\mathrm{His} 143$ of each $B$ chain) and is expelled during oxygenation (12). The binding of 2,3-DPG to human $\mathrm{Hb} \mathrm{F}$ is much lower because position 143 of the $\gamma$ chain is occupied by serine instead of histidine, eliminating this residue as a binding site. Fetal red cells have a similar level of 2,3-DPG as adult red cells; however, decreased binding affinity of $2,3-D P G$ to $H b F$ results in a higher $\mathrm{O}_{2}$ affinity, facilitating maternal to fetal $\mathrm{O}_{2}$ transport (13).

2. Genomic Organization of Human Globin Genes. The synthesis of the various globin chains is regulated by two gene clusters; the a-globin gene cluster is located on the tip of the short arm of chromosome 16, and the B-globin gene cluster on the short arm of chromosome 11 (Fig. 1/1) (14-27). The globin genes from both clusters are arranged from $5^{\prime}$ to $3^{\prime}$ in the order of their sequential expression during ontogenesis. A single globin gene encodes for each of the adult $\delta$ and $\beta$, as well as for the embryonic $\varepsilon$ and $\boldsymbol{\zeta}$ chains. The genes for the fetal $\boldsymbol{\gamma}$ and adult a chains are duplicated. 
The coding regions of the duplicated $\boldsymbol{\gamma}$ genes differ in one position; the $5^{\prime} \gamma$ gene $\left(G_{\gamma}\right)$ codes for glycine at position 136 , whereas the $3^{\prime} \gamma$ gene codes for alanine $\left(A_{y}\right)$. An interesting feature of both clusters is that the globin genes which are expressed at similar developmental periods are spaced relatively closely to one another, such as the two a loct, the 8 and $B$-globin gene pair, and the ${ }^{G} \gamma$ and $A_{\gamma-g l o b i n}$ genes, whereas larger distances separate the genes or gene pairs that are expressed at different developmental periods $\left(\zeta->a ; \varepsilon \rightarrow G_{Y} / A_{\gamma->\delta / B}\right)$. Apart from the genes that code for particular proteins, the a-globin gene cluster contains three genes $(\psi 5, \psi a 1, \psi a 2)$ and one gene of unknown function $(\theta 1)$, while there is only one gene $(\psi \beta)$ in the $\beta-g l o b i n g e n e$ cluster. It is believed that the genes have arisen by gene duplication events during evolution, and that they were inactivated by mutations in the coding and/or regulatory regions.

\section{Chromosome \#16}

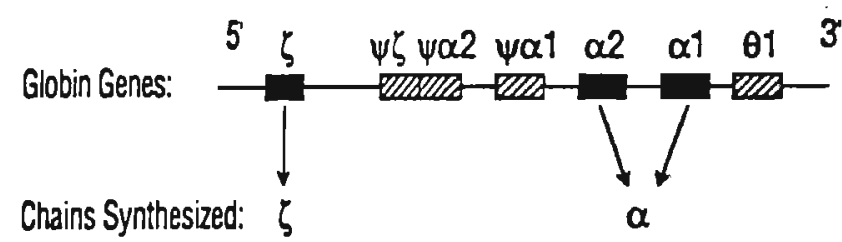

Hb Types:

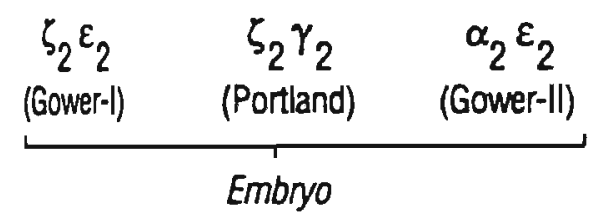

Chromosome \#11

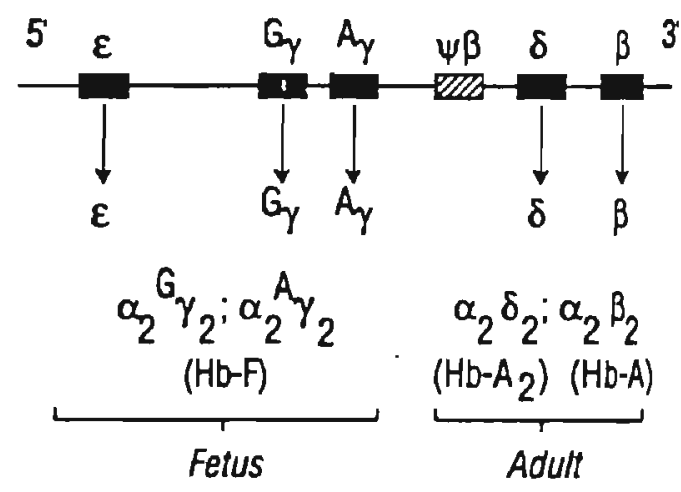

FI6. 1/1. Chromosomal organization of the a - and $B$-globin gene clusters. Black boxes represent functional genes. The major Hb types synthesized at particular developmental stages are also presented (from Ref. 1).

The general structure of a globin gene is presented in Fig. 1/2. Each globin gene consists of three coding regions (exons) which are separated by two intervening sequences (introns or IVS). The IVS are included in the precursor mRNA transcript in the nucleus, but are removed prior to expulsion of the mRNA to the cytoplasm by a process known as splicing (28). A crucial prerequisite for the proper splicing of globin and other mRNA molecules is the presence of specific nt sequences at the junctions between the exons and the introns; mutations in these conserved sequences can severely impair mRNA processing and have been associated with many thalassemic genes. The coding sequences of each gene are flanked by $5^{\prime}$ and $3^{\prime}$ UTR which are believed to play an important role in the Cap site formation, initiation of translation, and mRNA stability. A poly A signal (AATAAA) is located some 50 to $60 \mathrm{nts}^{\prime} 3^{\prime}$ from the termination $C D$ and is necessary for proper processing, polyadenylation, and cleavage of mRNA transcripts $(10,28)$. 
FI6. 1/2. Fine structure of a globin gene.

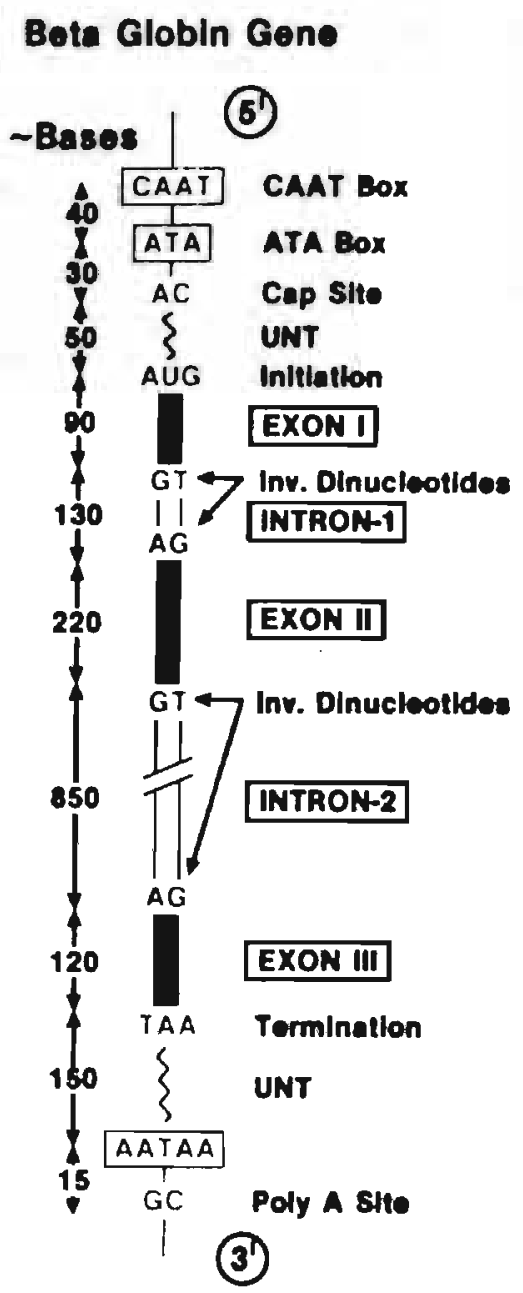

3. Globin Gene Expression During Development. Developmental changes in expression of the globin genes from the B-globin gene cluster are shown in Fig. 1/3. In early embryonic life, the $\mathrm{Hb}$ synthesis takes place in the yolk sac where it is mainly restricted to the embryonic Hb types, e.g. Hbs Gower-I and Gower-II, and Hbs Portland-I, Portland-II, and Portland-III (29). From the fifth to the 13th weeks after conception, hematopoiesis is shifted to the fetal liver with a consequent switch to a synthesis of $\mathrm{Hb} F$. The relative rate of production of the $G_{\gamma}$ and the $A_{\gamma}$ chains $\left(G_{\gamma}\right.$ to $A_{Y}=3: 1$ ) is constant throughout fetal life (30). The marrow starts to produce red cells during the second trimester and soon becomes the major erythropoietic site. This is accompanied by a gradual decrease in the production of $\gamma$ chains which is substituted by that of $\delta$ and $B$ chains. At birth, the ratio between the $B$ and $\gamma$ chains is about 1 to 4 ; however, slightly higher Hb $F$ values are observed in prematurely-born infants (31). The ratio between the two $\gamma$ chains at time of birth is still rather constant at $70 \% G_{Y}$ and $30 \% A_{\gamma}$, provided there are no rearrangements of the $\gamma$-globin genes (32). During the first few months of life $\mathrm{Hb} \mathrm{F}$ levels steadily decrease to about $2 \%$ in a normal 6-month-old baby, whereas the $G_{\gamma}$ to $A_{\gamma}$ ratio changes from $3: 1$ to $2: 3$ in about 3 to 4 months. In about 20 to $30 \%$ of 
the babies, the newborn ratto or $70 \% \mathrm{G}_{Y}$ and $30 \% A_{Y}$ is retained, as a result of a specific mutation in the $G$ promoter $(C+T$ at position -158) which promotes the production of the $G_{\gamma}$ chain (33). The decline in $\gamma$ chain production in babies with SS and some other hemoglobinopathies is much less striking; these infants often have $\mathrm{Hb} F$ levels of 20-40\% at the age of 1 year (32). The $H b F$ in adults $(<2 \%)$ is restricted to a small population of cells $(2-4 \%)$, termed $F$ cells, which also contain large amounts of $\mathrm{Hb} A$. The relative proportion of $\mathrm{F}$ cells is remarkably constant in different individuals and appears to be genetically determined. The level may be increased in certain acquired and inherited conditions (reviewed in Ref. 10).

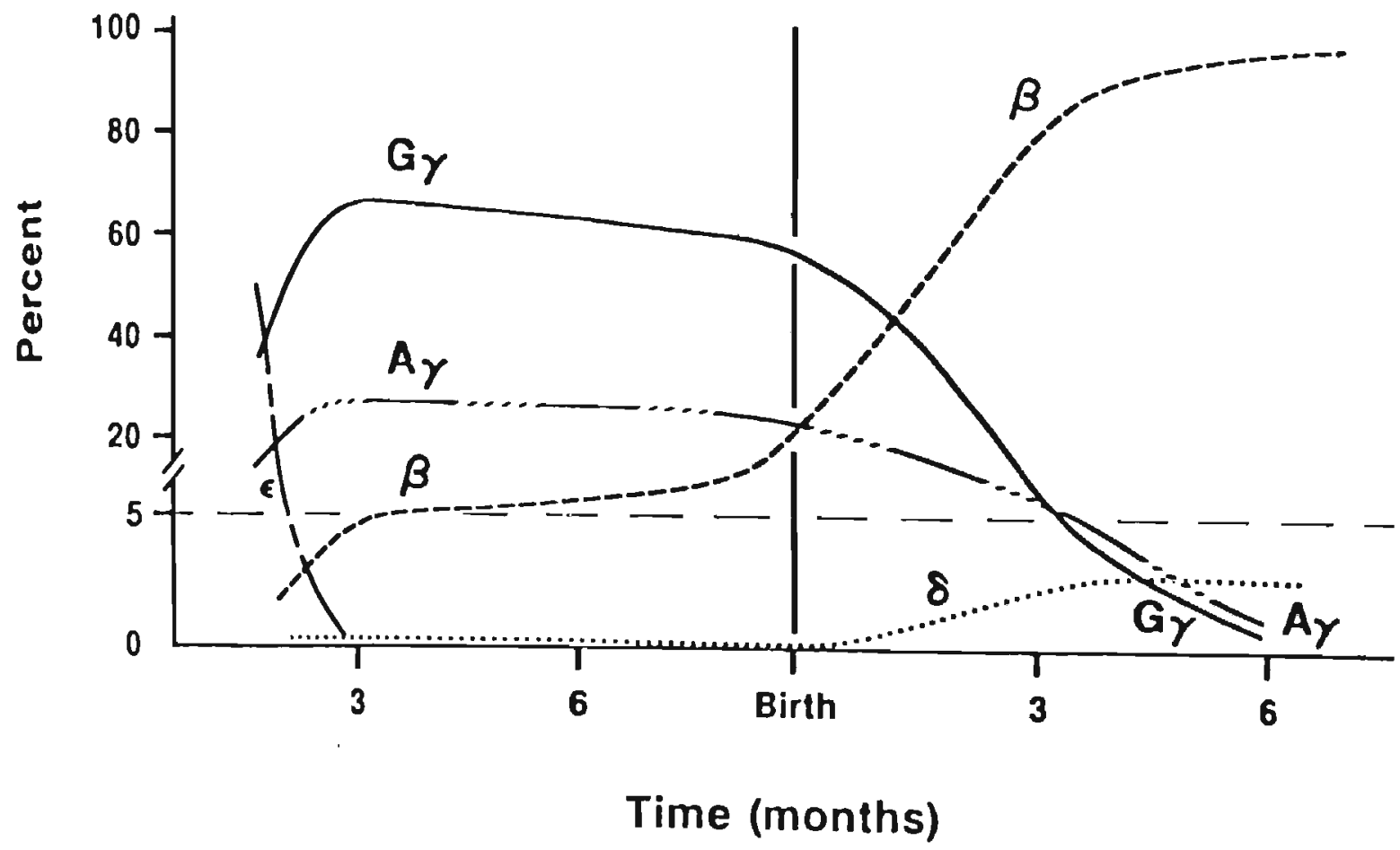

FI6. 1/3. Developmental expression of B-like globin genes (from Ref. 1).

The precise tissue and developmental expression of the globin genes has been studied extensively because of the potential therapeutic implications of the reversed "switching" in patients with $B$-thal and SS $(10,28$, 29,34). Although the entire picture has not yet been revealed, much is known about the molecular basis of globin gene expression. It appears to be regulated at the level of gene transcription: a) by local (promoters, enhancers, and silencers) and distant (LCR) cis-acting control DNA sequences, and b) by trans-acting regulatory proteins which bind to the regulatory DNA sequences. Post-synthetic DNA modification like DNA methylation (35) and histon acetylation (36) appears to have effects on the expression of individual globin genes as well.

Promoter sequences are located within 200-300 bp $5^{\prime}$ to the Cap site of the gene and consist of several conserved sequences which interact with specific DNA binding proteins. The latter are necessary for the assembly of the transcription-initiation complex and its correct positioning with 
respect to the start site of transcription, as well as for the modulation of the efficiency of transcription (37-39). The most proximal element located 30 nts $5^{\prime}$ from the cap site is rich in adenine and thymine, and is referred to as the TATA box. This element appears to be directly involved in the definition of the exact transcriptional start site, through binding of the TFIID as part of the basal transcriptional machinery. The second conserved element, located at about -70 , has the consensus structure 6GC(T) CAATCT and is referred to as the CAT box. It is duplicated in the $r$ gene promoter and is found in the promoter region of many other genes. At least two nuclear binding proteins, designated $C D P$ and $C P 1$, are known to bind to this sequence. The most distal element of the globin gene promoters is located between positions -90 and -105 and is designated as the CAC box, which is duplicated in the B-globin gene promoter and is absent in the promoter of the $\delta-g l o b i n g e n e$.

Enhancers are DNA sequence elements that influence the level of transcription in a positive fashion, irrespective of distance from or orientation relative to the target gene $(40,41)$. An enhancing activity has been detected within the $B-g l o b i n$ gene IVS-II region (42), and additional enhancer elements have been located about $1 \mathrm{~kb}$ downstream of both the $A_{\gamma}$ (43) and B-globin genes (44). Enchancers comprise clusters of binding motifs for several specific regulatory factors (SP1, GATA, NFE-2) and it is believed that they are involved in the stage specific expression of individual globin genes. The only well-defined silencer element in the $\varepsilon$-globin gene cluster is located between -182 to -467 bp upstream of the $\varepsilon$-globin gene (45). This element is necessary for the proper regulation of the $\varepsilon$ globin gene during development and its silencing during the transition from embryonic to fetal expression. An (AT) X(T)Y repeat motif found in the $\beta-$ globin $5^{\prime}$ flanking region has been suggested to bind the ubiquitous $B P 1$ protein, which is believed to be a negative regulatory transacting factor (46). It has been postulated that the (AT) $g(T)_{5}$ motif is associated with a stronger binding of the BPI protein than is seen with the more common $(A T)_{7}(T)_{7}$ motif (47). The former is found in the Indian $B$ S haplotype (48), and has also been described in several individuals with silent $B$-thal $(49,50)$. Details of the association between this polymorphic motif and $\mathrm{Hb} F$ levels in various forms of $B$-thal are described elsewhere in this dissertation.

The B-globin LCR is located 6 to $20 \mathrm{~kb}$ upstream of the $\mathrm{E}$ gene and consists of four DNase I HS (5'HS-1, $5^{\prime} \mathrm{HS}-2,5^{\prime} \mathrm{HS}-3$, and $5^{\prime} \mathrm{HS}-4$ ) $(51,52$ ). A single DNase I HS is found $20-21 \mathrm{~kb} 3^{\prime}$ of the $B$ gene ( $3^{\prime} \mathrm{HS}-1$ ). The significance of this region was highlighted by the discovery of naturally occurring deletions in man which remove the LCR and render the remaining globin genes in cis inactive (53-55). It has been shown that the LCR confers high-level erythroid-specific copy number-dependent expression on cis-linked genes in transgenic mice (56). It affects the chromatin organization of the $B-g l o b i n g e n e ~ c l u s t e r ~(57)$ and regulates the sequential transcription of the individual genes during ontogenesis (58). Experimental data suggest a mechanism of globin gene switching based on competition between individual genes for the $\operatorname{LCR}$ sequences $(59,60)$. This process is mediated through nuclear proteins which bind to the regulatory sequences in the vicinity of the genes as well as the LCR, favoring particular genes 
at certain developmental stages of hematopoiesis. The activity of each HS is restricted to a core sequence of about 200 to 500 bp which contain binding motifs for important regulatory proteins, including the erythroidspecific activator GATA-1 (61-63). Variations in these core sequences among the various $\beta^{S}$ and $\beta$-thal chromosomes with respect to $\mathrm{Hb} F$ expression in SS and $\beta$-thal are discussed in great detail in later chapters of this dissertation.

4. DHA Polymorphisms. In contrast to the coding regions, which show little or no variability between individuals, the intergenic DNA in the $\alpha$ and $\beta-g l o b i n g e n e$ clusters, and the sequences in the intervening regions of the globin genes vary significantly from one person to another. If a particular sequence occurs at a frequency of more than $1 \%$ in a certain population it is called a polymorphism. It has been suggested that these variations were generated during evolution due to a lack of the deleterious effects of the organism, i.e. the lack of functional constraints on their preservation.

Polymorphisms have been initially detected by gene mapping procedures using various restriction enzymes which cleave the DNA at particular sequences. Variability in the sizes of the fragments observed among different individuals is referred to as RFLP. The RFLP can be generated by: a) single base substitutions at the recognition sequence of a particular enzyme, and b) variable number of tandemly repeated sequences between two consecutive restriction endonuclease sites; these types of polymorphisms are found only in the a-globin gene cluster (64).

The first RFLP reported was an $\mathrm{Hpa} I$ polymorphism located about $7 \mathrm{~kb}$ $3^{\prime}$ from the $\beta-g l o b i n$ gene (65). Ever since, more than 20 polymorphisms have been detected in the $B-g$ lobin gene cluster $(66,67)$. Most of these are located in the intergenic and in the IVS regions, and are quite common and widely distributed among different racial groups. Other polymorphisms are relatively rare (for instance the Pst I site in $\delta$-IVS-II) (17), or are restricted to certain racial groups (Hpa I $3^{\prime}$ to $B$ in Blacks) (65). It is worth noting that these polymorphisms do not occur in association with one another in a totally random fashion; the non-random association of a set of polymorphic restriction sites is referred to as "linkage disequilibrium". A specific combination of several polymorphic restriction sites defines a particular haplotype $(66,67)$.

Haplotypes were initially used as chromosomal markers in association with $\beta$-thalassemic genes for, among others, the prenatal diagnosis of $\beta$-thal (68), for the studies involving the history of the normal cluster, in population studies, and for the estimation of the recombination frequency within a cluster $(69,70)$. The association of chromosomal haplotypes with particular $\beta$-thal mutations within certain populations has been used for the determination of the molecular defects of $B$-thal and for the detection of novel mutations in a particular population (67).

The association of the ${ }_{B} S$ mutation with particular haplotypes has given information about the independent occurrence of this mutation for at least five different locations in the world (71-75). These haplotypes have been 
named Benin, Bantu (CAR), Senegal, Saudi Arabian/Indian, and Cameroon, and were identified as haplotypes $\# 19, \# 20, \# 3, \# 31$, and $\# 17$, respectively. Fig. 1/4 gives details of the restriction sites which define each of these haplotypes.

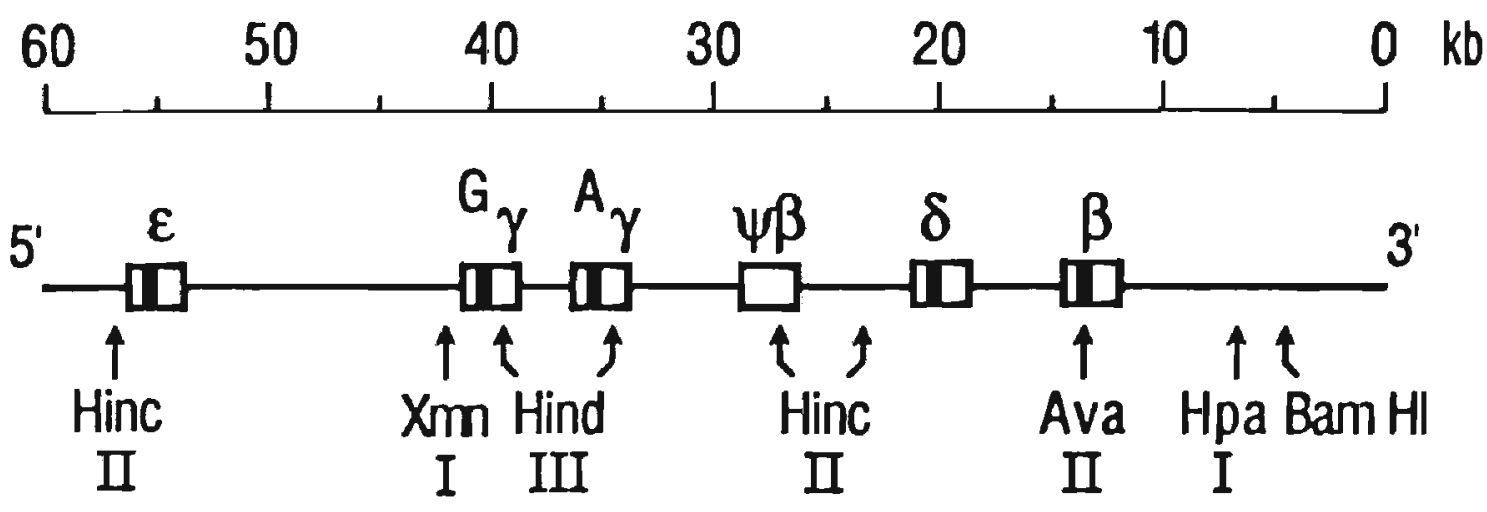

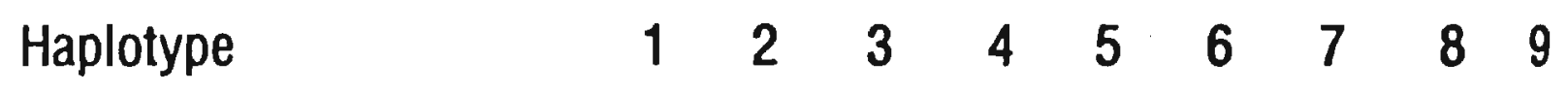

\begin{tabular}{llllllllll} 
Saudi Arabian/lndian (\#31) & + & + & + & - & + & + & + & + & - \\
Senegal (\#3) & - & + & + & - & + & + & + & + & + \\
Benin (\#19) & - & - & - & - & - & + & + & - & + \\
Bantu (\#20) & - & - & + & - & - & - & + & + & + \\
Cameroon (\#17) & - & - & + & + & - & + & + & & + \\
\hline
\end{tabular}

FI6. 1/4. Commonly used restriction enzymes in the determination of the major $B S$ haplotypes (from Ref. 1).

Haplotypes are also used as genetic markers for $\beta$-thal and ${ }_{\beta} S$ chromosomes which are associated with a high $H b F$ expression, and thus with a milder clinical course of these diseases. Sequence analyses of the regulatory regions of these chromosomes, e.g. $r$ gene promoters, IVS-II, and LCR, have detected numerous differences which were specific for particular haplotypes. The structure/function relationships of these sequence differences with the variations in the $\gamma$ chain synthesis are discussed in other chapters of this dissertation.

5. Sickle Cell Anemia. SS was first described in the western literature by Herrick in 1910 (76). In 1917, Emmel (77) introduced a simple test for demonstrating the sickling phenomenon; he found that a suspension of a patient's red cells would assume the sickle shape when sealed between a glass slide and cover slip. The next major discovery was by Linus Pauling and associates in 1949 (78), who showed that the basic abnormality in SS was altered electrophoretic mobility of the Hb. In 1956 Ingram (79) demonstrated the glutanic acid to valine replacement at the sixth position in the $B$ chain. 
The pathophysiology of SS is related to the decreased solubility of $\mathrm{Hb} \mathrm{S}$, especially in situations of low $\mathrm{O}_{2}$ tension. High concentrations of deoxy-Hb 5 molecules form tactoids or polymers which distort the red cell membrane (80). This polymerization is reversible on re-oxygenation; however, after several cycles of sickling and unsickling, the RBCs become irreversibly sickled, and subsequently removed from circulation by the reticulo-endothelial system, especially the spleen (81). Thus, SS is characterized by a chronic hemolytic anemia. The increased rigidity of the RBC membrane promotes vascular occlusion, which is responsible for the painful crises and organ damage which complicate the disease. Sickling is dependent on several factors including temperature, $\mathrm{pH}$, and intracellular Hb S concentration (reviewed in Ref. 10).

SS occurs in most parts of Africa and in the Mediterranean countries, the Middle East, and the Indian subcontinent $(82,83)$. There is evidence that a heterozygosity for $\mathrm{Hb} S$ or $H b$ AS confers appreciable protection against the complications of $P$. falciparum malaria (84) which probably results in a preferential selection of the gene as an example of balanced polymorphism. Haplotyping studies have established that the ${ }_{B} S$ mutation originated independentiy several times on chromosomes of different genetic backgrounds (71-75). Five common haplotypes (Benin, Bantu, Senegal, Saudi Arabian/Indian, and Cameroon) have been described and each is associated with different parts of Africa, Saudi Arabia or India, from where each is believed to have originated (Fig. 1/5). The presence of the Benin haplotype (\#19) in the Mediterranean Basin has been associated with migrations across the Sahara, while its presence on the American continent and the Caribbean is attributed to slavery from different parts of Africa $(82,83)$.

The clinical course of the disease is variable (85). Some affected individuals suffer from repeated crises and severe organ damage, whereas others go through life with little disability. There are several environmental and genetic factors that exert an epistatic effect on the clinical course of the disease. Although no controlled data are available, there is a clinical impression that milder disease occurs in patients with better socioeconomic conditions (86). Other environmental factors include good nutrition, adequate medical care, and endemic infections, e.g. malaria (87). The most studied genetic factors are the a-thal which is co-inherited and elevated levels of $\mathrm{Hb} F$ (reviewed in Refs. 88 and 89). A co-existing $\alpha$-thal has a marked effect on the red cell characteristics in SS through lowering both the MCHC and MCV $(89,90)$. The decreased MCHC inhibits the rate of polymer formation and hence, intravascular sickling which leads to less irreversibly sickled cells and a greater red cell survival. a -Thal may also decrease the number of dense cells and improve the deformability of the cells in SS (91).

Several clinical studies have demonstrated an inverse correlation between $H b F$ levels and complications of SS, especially splenomegaly (92), splenic sequestration (93), stroke, and aseptic necrosis of the head of the femur (94). This effect is most likely exerted through inhibition of polymerization of $\mathrm{Hb} S$ by the formation of a soluble asymetric hybrid $\left(\alpha_{2} \gamma B^{S}\right)$ (95-97). Hofrichter et al (98) demonstrated that mixtures of $H b S$ and $\mathrm{Hb} A$ or $\mathrm{Hb} F$ showed a prolonged time prior to polymerization when compared to pure $\mathrm{Hb} S$; the effect was considerably more marked with $H b \mathrm{~F}$ than 
with $\mathrm{Hb}$ A. It was suggested that this prolonged delay time might be sufficiently long for the RBCs to return to the lungs for re-oxygenation, or at least to escape from the microvasculature prior to polymerization. Using

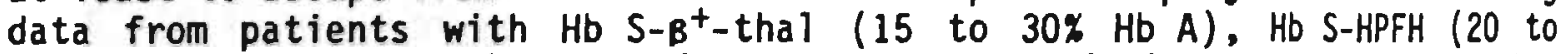
$30 \% \mathrm{Hb} \mathrm{F})$, and $\mathrm{Hb}$ AS $(60 \% \mathrm{Hb} \mathrm{A})$, Sunshine et al (99) were able to predict the changes in delay time which would have to be produced by a therapeutic agent to result in less severe disease, much less severe disease, or no disease.

\section{MAP OF AFRICA AND SOUTHERN EUROPE SHOWING PREDOMINANT HAPLOTYPES}

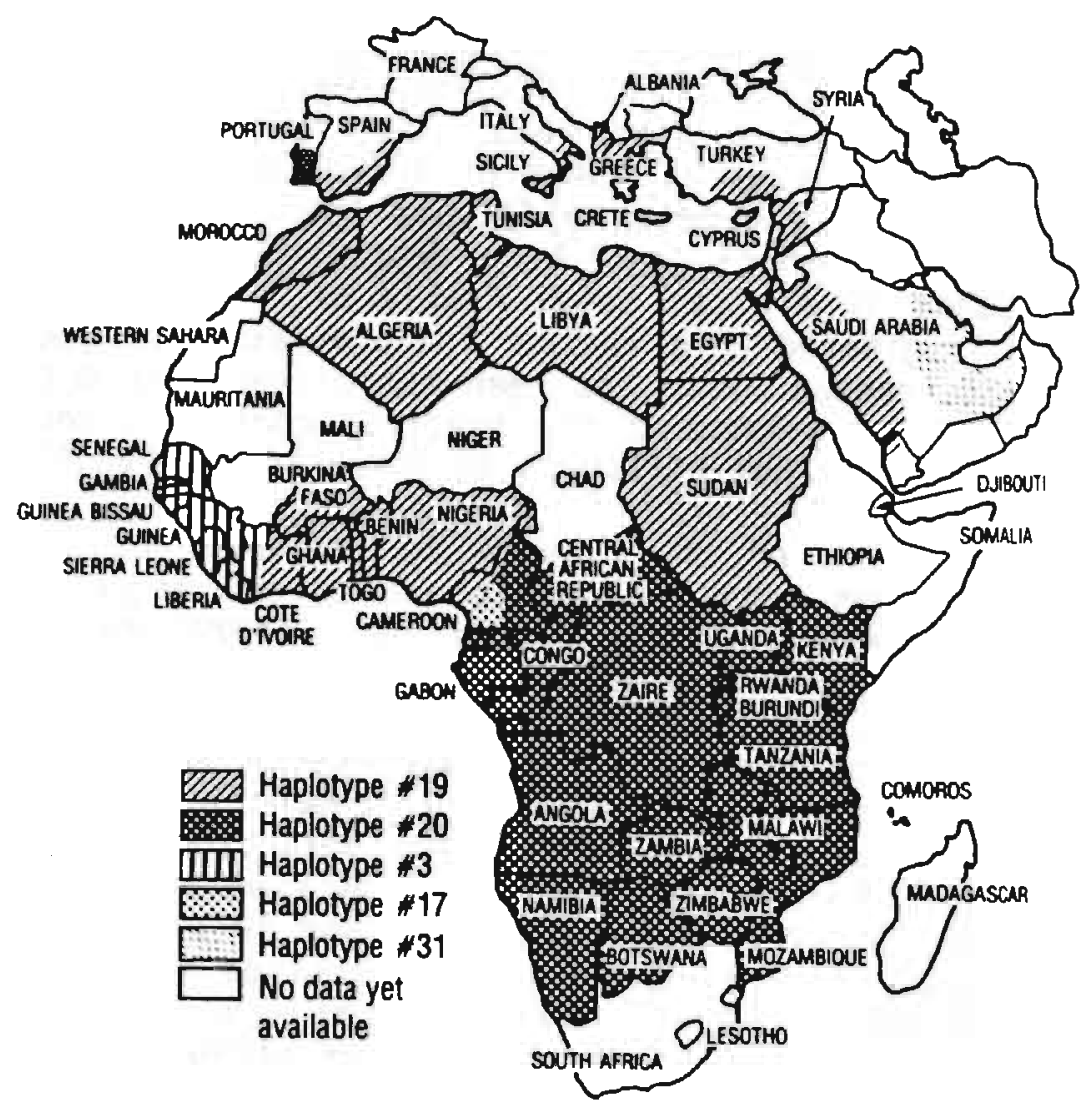

FIG. 1/5. Distribution of ${ }_{B} S$ haplotypes in Africa and the Mediterranean countries (from Ref. 1).

$\mathrm{Hb} F$ in SS patients is distributed heterocellularly and is confined to a subset of erythrocytes, termed $F$ cells (100). The levels of Hb $F$ in these patients is extremely variable. Because of uneven distribution, differences in peripheral blood $H b F$ levels may be attributed to differences in the production of $F$ cells, variation in the amount of $H b F$ per $F$ cells, and the preferential survival in the peripheral circulation of $F$ cells compared with RBCs containing no detectable Hb F (101). 
Several studies have shown that either $F$ cells or Hb F levels in nonanemic AS parents predicted $H b F$ production in their SS children (reviewed in Ref. 89). The broad distribution of $\mathrm{Hb} F$ levels in SS patients suggests that several factors may control $\mathrm{Hb} F$ production; these are:

5/a The age of the individual. Hb $F$ levels remain far above the percentages observed in normal persons of comparable age and this elevation is independent of sex, a-globin gene status, and haplotype (89), although data from some other studies make this less certain (Adekile and Huisman, unpublished data). Presumably a severe hematopoietic stress exerts its effect in these young, growing patients.

5/b The gender. Studies of a large series of patients have shown that the levels of $H b F$ are somewhat higher in females than in males in all age groups (102). Nagel and Ranney (82) have suggested that a factor, linked to the $X$ chromosome, influences the level of $H b F$ in normal individuals as well as in SS patients. Females, carriers of two $X$ chromosomes, may be homozygous for this factor and hence express higher levels of $\mathrm{Hb} F$. Recent studies by Miyoshi et al (103) and Dover et al (104) have given substantial evidence that the differences in $F$ cell production between males and females is attributed to an X-linked factor, presumably located at xp22.2.

$5 / c$ The co-existence of a severe a chain deficiency decreases the level of $\mathrm{Hb} \mathrm{F}$ because the formation of $B^{5}$ dimers is preferred over that of ar dimers when the a chain pool is greatly decreased $(90,105)$. Moreover, the lower levels of $H b F$ in SS patients with a-thal is due to the preferred survival of non $F$ cells because of decreased MCHC values in these patients.

5/d Several studies on large series of SS patients have established a close relationship between the chromosomal background, e.g. haplotypes and the levels of $\mathrm{Hb} \mathrm{F}$ and ${ }^{G} \boldsymbol{Y}$. SS patients of Saudi Arabian/Indian origin, homozygous for haplotype $\# 31$, are of particular interest because of a mild clinical picture and high $\mathrm{Hb} F(25-20 \%)$ and high $\mathrm{G}_{Y}$ values $(70 \%)(106-108)$. It has been suggested that an HPFH determinant is linked to the $B$ mutation on this chromosome. Hattori et al (75) were the first to study the relationship between haplotypes, hematological indices, $\mathrm{Hb} \mathrm{F}$, and $\mathrm{G}_{\mathrm{r}}$ values in Black American patients. These studies and those by others indicated that the presence of at least one chromosome with haplotype \#3 (Senegal) is sufficient to improve the hematological data, and to increase the $H b F$ and $G_{y}$ values (109). Ballas et al (110) extended the studies mainly to haplotype \#3 homozygotes and demonstrated a significant correlation between the presence of this haplotype and increased $G_{\gamma}$ values in a dose-dependent manner. A recent multi-center study on a large number of adult SS patients has also confirmed the relationship of the chromosomal background and the $\mathrm{Hb} F$ levels (111). The presence of single nt substitutions in the promoter regions of

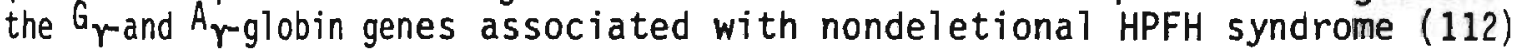
have prompted a search for specific changes in the $5^{\prime}$ flanking region of the rglobin genes on these chromosomes. Miller et al demonstrated the presence of a $C+T$ substitution at position $-1585^{\prime}$ to the ${ }^{G} \gamma$ gene on a chromosome with haplotype \#31 $(113,114)$. Two mutations have been reported in association with haplotype $\# 20\left[C+T\right.$ substitution at position $-2715^{\prime}$ to $A_{Y}(115)$ 
and a 6 bp deletion in the ${ }^{G} Y$ promoter (116)], and one associated with haplotype \#19 (C+G at position $-3095^{\prime}$ to $\left.G_{Y}\right)(117)$. Recently, Beldjord et a) (118) have reported a 4 bp deletion around position $-2255^{\prime}$ to the $A_{\gamma}$ globin gene associated with haplotype \#17 chromosomes.

We have extended these studies to a larger portion of the $5^{\prime}$ flanking and IVS-II regions of both the $G_{\gamma-}$ and $A_{\gamma-g l o b i n}$ genes on chromosomes defined by the five major $B S$ haplotypes, namely $\# 19, \# 20, \# 17, \# 31$, and \#3 $(119,120)$. The core sequences of the LCR (5'HS-3, $5^{\prime} H S-3$, and $\left.5^{\prime} H S-4\right)$ have also been evaluated $(121,122)$. A simple PCR-based procedure established with the previous experiments, was used for the determination of the haplotype background on a large series of patients from all over the world (123). The various differences observed and their relevance to the $H b F$ and $G_{Y}$ expression in SS patients are discussed in detail later in this dissertation.

$5 / e$ Variations in the $(A T) \times(T) Y$ repeated sequences $5^{\prime}$ to the $\beta$ gene. An alternative theory for the variable clinical course of sickle cell disease has recently been proposed by Elion et al (48). They have studied the $(A T)_{X}(T)_{Y}$ polymorphic region at position $-5305^{\prime}$ to the $B-g$ lobin gene and have found specific variations associated with particular haplotypes affecting the binding of the putative repressor nuclear protein named BP1. The tighter binding of this protein with the polymorphic pattern associated with the chromosome with haplotype \#31, as well as lower levels of Hb $S$ in AS heterozygotes with Indian origin have been observed $(47,48)$. The authors suggest that the ${ }_{\beta} S$ gene on that chromosome is "thalassemic", which in addition to other genetic variables such as increased $H b F$ and a-thal, contributes to the determination of the intracellular polymerization and thus to the severity of the SS condition.

6. $\quad$ b $F$ in $B$-Thal. $B$-Thal is a heterogeneous group of disorders characterized by a decreased $\left(\beta^{+}-\right.$thal) or absent ( $\beta^{\circ}$-thal) production of $\beta$-globin chains relative to $\gamma-g l o b i n$ chains in adult erythroid cells (124). It has a worldwide distribution, with high frequencies in areas of malaria endemicity such as the Mediterranean Basin, India, and Southeast Asia.

The basic pathophysiology phenomenon in the $B$-thal syndrome is globin chain imbalance. Deficient or absent $\beta-g l o b i n$ chain production results in an excess of a chains, which precipitate in the developing RBC precursors in the bone marrow, and ultimately lead to damage of the membrane and cellular organelles. Clinical severity of the disease is directly correlated with the chain imbalance. Factors that decrease the chain imbalance, such as co-inherited $\alpha$-thal (by decreasing a chain production) or high $H b F$ expression (by compensating for the decreased $B$ chain synthesis) ameliorate the clinical course of the $\beta$-thal syndromes $(10,124)$.

The clinical and hematologic features of $\beta$-thal are manifested several months after birth, when the fetal to adult $\mathrm{Hb}$ switching is completed. Phenotypes associated with different $B$-thal syndromes show a wide variability. Individuals who are carriers or heterozygotes for a single $\boldsymbol{B}$-thal allele are clinically healthy and usually present with mild microcytic, 
hypochromic anemia. An important feature of the $\beta$-thal heterozygotes is the elevation of the minor adult $\mathrm{Hb}$, $\mathrm{Hb} \mathrm{A}_{2}$, to approximately twice its normal level (4-6\%) (reviewed in Ref. 125). Hb $F$ is often present in the normal levels $(\langle 1 \%)$, but in about $50 \%$ of all heterozygotes it is elevated to 1 to $5 \%$.

The $\beta$-thal homozygotes who carry two $\beta$-thal genes are extremely heterogeneous in their clinical presentation, al though the large majority presents with profound anemia during the first 6 months to 1 year of life with striking RBC abnormalities, including hypochromia, microcytosis, anisocytosis, poikilocytosis, polychromasia, fragmentation, and basophilic stippling. Patients who do not receive adequate therapy also exhibit hepatosplenomegaly, growth retardation, and skeletal deformities. The course of the disease is further complicated by an iron overload due to transfusion, and consequent parenchymal organ damage, and ultimately death in the second or third decade of life. However, the outlook of the disease has changed significantly in the last two decades (particularly in the developed countries) as a consequence of the early institution of hypertransfusion regimens, coupled with aggressive iron chelation therapy (126). Bone marrow transplantation is an alternative mode of therapy, although it is limited by the avallability of compatible donors, high cost, and inherent complications, especially in patients in poor clinical condition (127).

The existence of clinical syndromes with features between those observed in patients with a severe $\beta$-thal and in clinically asymptomatic $\beta$-thal heterozygotes are known as $\beta$-thal intermedia. Most patients with this syndrome maintain functional $\mathrm{Hb}$ levels without blood transfusions. Clinical and genetic observations in patients with $B$-thal intermedia have led some investigators, long before the era of molecular biology, to propose that the $\beta$-thal genes are heterogeneous (128).

With the development of the techniques of molecular biology, especially with the introduction of the PCR procedure (129), the molecular basis of the $\beta$-thal have been almost completely characterized. In contrast to $\beta$-thal and complex $\beta$-thal (conditions such as $\delta \beta$ - and $\varepsilon \gamma \delta \beta$-thal) which are caused by large deletions, the vast majority of $\beta$-thal alleles result from single

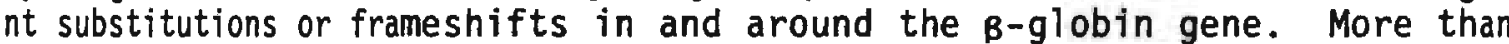
130 point mutations or deletions/insertions of a few nts affecting the B-mRNA transcription, processing or translation, have been described (130). Large deletions associated with $\boldsymbol{B}^{\circ}$-thal and removing a part of or the whole B-globin gene are relatively rare; only 11 have been described so far (130). These studies have provided important information about the normal mechanisms of globin chain synthesis and have helped in establishing programs for prenatal diagnosis.

The evaluation of $\mathrm{Hb} F$ production in homozygous patients with severe B-thal is difficult because these patients are usually on regular blood transfusions from early childhood which suppress endogenous $\mathrm{Hb}$ synthesis (124). However, it has been shown that there is a remarkable variability in the amount of $\mathrm{Hb} F /$ red cell in the peripheral blood of $B$-thal patients (131). The differential centrifugation studies have shown higher values of $\mathrm{Hb} \mathrm{F}$ in the older cells, suggesting a preferential survival in the bone 
marrow and peripheral blood (132). Comparing the absolute levels of $\mathrm{Hb} F$ in normal adults and in untransfused homozygous $B$-thal patients, Weatherall and associates (133) have suggested that the increased $\mathrm{Hb} F$ levels in $\beta$-thal patients are not due to increased synthesis of $\gamma$ chains but due to the 20 30-fold expansion of erythron and selective survival of the $F$ cell precursor in this expanded erythron.

Patients presenting with $B$-thal intermedia due to increased $\gamma$-globin gene expression provide a better opportunity of evaluating the overall $\gamma$ chain synthesis. Studies from several laboratories have indicated that the increased $\gamma$ chain expression in $B$-thal is linked to the chromosomal background, e.g. haplotype of the $\boldsymbol{\beta}$-thal chromosome (134-136). It has been shown that $B$-thal patients from Mediterranean countries with $\beta$-thal determinants that are linked to haplotype III, IV, and IX [nomenclature by Orkin et al (67)] are associated with a marked $H b F$ expression (mainly $G_{Y}$ ) and with a mild course of the disease. The chromosomes with these haplotypes carry the $-158 \quad(C, T)$ mutation in the $G_{Y}$ promoter and it has been suggested that the chromosomes with this mutation are capable of sustaining a continuous production of $\gamma$ chains under the conditions of hematopoietic stress. The same observations have been made by Gonzalez-Redondo et al (137) in a group of Black B-thal homozygotes from the Southeastern United States. However, the great variability of the levels of $\mathrm{Hb} F$ among patients who are members of the same family, makes it likely that genetic factors other than those linked to the $B$-globin gene cluster are also influencing the levels of $H b F$ in $B$-thal.

The importance of the mutations in the $r$-globin gene promoters linked to the $B$-thal determinant is also indicated by data from the molecular characterization of the so-called Sardinian $\delta \beta$-thal (138). In contrast to other $\delta \beta-$ thal determinants (all result from large deletions in the $\beta-g l o b i n g e n e$ cluster) the Sardinian $\delta B$-thal chromosome is associated with the common $C D 39$ nonsense mutation in the $B-g l o b i n$ gene and the $C+T$ substitution at

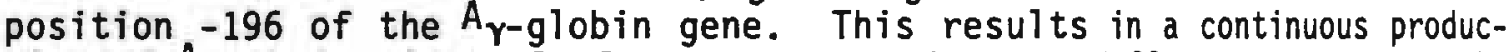
tion of $A_{Y}$ chains in adult life, and may thus partially compensate for the shortage of the $\beta-1$ ike globin chains resulting from the $\beta$-thal defect.

Recently, Ragusa et al have postulated that the polymorphic (AT) $X(T)_{Y}$ motif ( $-5405^{\prime}$ to the $B-g l o b i n$ gene) interacts with the $-158 \mathrm{G}_{Y} \mathrm{C}_{-} \mathrm{T}$ mutation to enhance the expression of $\mathrm{Hb} F$ in $B$-thal homozygotes (139). The polymorphic patterns of this motif in a large series of $B$-thal homozygotes with different mutations is presented and discussed later in this dissertation.

In the early 1960s, Beavan et al published their extensive studies on $\mathrm{Hb} F$ levels in normal adults and adults with hereditary hemoglobinopathies and thalassemias (140-142). Using an alkali denaturation procedure, they observed $\mathrm{Hb} F$ levels below $1 \%$ in normal healthy adults, while $H b F$ was modestly elevated in about half of the $B$-thal heterozygotes. Recently, Kutlar et al (143) determined the $H b F$ and $G_{Y}$ levels with a more accurate HPLC method in a group of $B-$ thal heterozygotes whose mutations have been previously characterized. They found that the $-158 G_{\gamma} C_{+} T$ mutation is associated with high $G_{Y}$ but not with higher $H b F$ in B-thal heterozygotes with different mutations, and concluded that other factors, some of which may 
not be linked to the $\beta-g$ lobin gene cluster, are responsible for the modest elevation of $\mathrm{Hb} F$ sometimes observed in this condition.

Elevated levels of $\mathrm{Hb} F$ and unusually high $\mathrm{Hb} \mathrm{A}_{2}$ levels have been found in $\beta$-thal heterozygotes with deletional types of $B^{\circ}$-thal (reviewed in Ref. 144). It has been postulated that the observed phenotype is due to the loss of the $\beta$-globin gene promoter region which would allow the remaining $\delta$ - and $\gamma$-globin gene promoters to react more readily with the enhancer element(s) located in the LCR (60). Two new deletions associated with $\beta^{\circ}$-thal are described in this dissertation; included is a discussion of the relevance of this phenotype to the molecular mechanisms of globin gene expression in these syndromes.

\section{References}

1. Huisman, T.H.J.: The structure and function of normal and abnormal haemoglobins. in The Haemoglobinopathies, edited by D.J. Weatherall and D.R. Higgs, Bailliere's Clinical Haematology, Vol. 6, page 1, W.B. Saunders Company, London, 1993.

2. Kunkel, H.G. and Wallenius, G.: New hemoglobin in normal adult blood. Science, 122:288, 1955.

3. Huehns, E.R., Flynn, F.V., Butler, E.A., and Beaven, G.H.: Two new haemoglobin variants in a very young human embryo. Nature, 189:496, 1961.

4. Capp, G.L., Rigas, D.A., and Jones, R.T.: Evidence for a new haemoglobin chain ( $\zeta$ chain). Nature, 288:278, 1970.

5. Randhawa, Z.I., Jones, R.T., and Lie-Injo, L.E.: Human Hemoglobin Portland II $\left(\zeta_{2} \beta_{2}\right)$ : Isolation and characterization of Portland hemoglobin components and their constituent globin chains. J. Biol. Chem., 259:7325, 1984.

6. Konigsberg, W. and Hill, R.J.: The structure of human hemoglobin. III. The sequence of amino acids of the tryptic peptides of the a-chain. J. Biol. Chem., $237: 2547,1962$.

7. Goldstein, J., Konigsberg, W., and Hill, R.J.: The structure of human hemoglobin. VI. The sequence of amino acids in the tryptic peptides of the Bchain. J. Biol. Chem., 238:2016, 1963.

8. Schroeder, W.A., Shelton, J.R., Shelton, J.B., Cormick, J., and Jones, R.T.: The amino acid sequence of the $\gamma$-chain of human fetal hemoglobin. Biochemistry, 2:992, 1963.

9. Fermi, G. and Perutz, M.F.: Haemoglobin and Myoglobin, edited by D.C. Philips and F.M. Richards, Atlas of Molecular Structures in Biology, Clarendon Press, Oxford, 1981.

10. Bunn, H.F. and Forget, B.G.: Hemoglobin: Molecular, Genetic and Clinical Aspects, W.B. Saunders Company, Philadelphia, 1986.

11. Bohr, C.: Theoretische Behandlung der quantitativen Verhaltuis bei der Sauerstoffaufnahine des Hemoglobins. Zbl. Physiol., 17:682, 1904.

12. Chanutin, A. and Cunish, R.R.: Effect of organic and inorganic phosphates on the oxygen equilibrium of human erythrocytes. Arch. Biochem. Biophys., 121:96, 1967.

13. Delavoria-Papadopoulos, M., Roncevic, N.P., and Oski, F.A.: Postnatal changes in oxygen transport of term, premature and sick infants: The role of red cell 2,3 diphosphoglycerate and adult hemoglobins. Pediatr. Res., 5:235, 1971. 
14. Maniatis, T., Kee, S.G., Efstratiadis, A., and Kafatos, F.C.: Ampli-

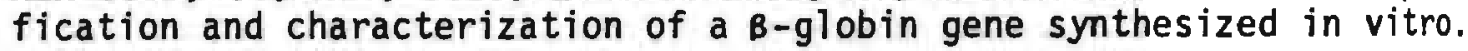
Ce]1, 8:163, 1976.

15. Little, P., Curtis, P., Coutelle, C.H., van den Berg, J., Dalgleish, R., Malcolm, S., Courtney, M., Westaway, D., and Williamson, R.: Isolation and partial sequence of recombinant plasmids containing human $\alpha-, B-$, and $\gamma-g l o b i n$ cDNA fragments. Nature, 273:640, 1978.

16. Mears, J.G., Ramirez, F, Leibowitz, D., and Bank, A.: Organization of human $\delta$ - and $B-g$ lobin genes in cellular DNA and the presence of intragenic inserts. Cell, 15:15, 1978.

17. Lawn, R.M., Fritsch, E.F., Parker, R.C., Blake, G., and Maniatis, T.: The isolation and characterization of linked $\delta$ and $B$ globin genes from a cloned library of human DNA. Cel1, 15:1157, 1978.

18. Fritsch, E.F., Lawn, R.M., and Maniatis, T.: Molecular cloning and characterization of the human B-globin gene cluster. Cell, 19:959, 1980.

19. Lauer, J., Shen, C-K.J., and Maniatis, T.: The chromosomal arrangement of human $\alpha-1 i k e$ globin genes: Sequence homology and $\alpha-g l o b i n$ gene deletions. Cel1, 20:119, 1980.

20. Baralle, F.E., Shoulders, C.C., and Proudfoot, N.J.: The primary structure of the human $\varepsilon$-globin gene. Ce11, 21:621, 1980 .

21. Slightom, J.L., Blech1, A.E., and Smithies, 0.: Human fetal $G_{Y}$ and $A_{Y}$ globin genes: Complete nucleotide sequences suggest that DNA can be exchanged between these duplicated genes. Ce11, 21:627, 1980.

22. Spritz, R.A., deRiel, J.K., Forget, B.G., and Weissman, S.M.: Complete nucleotide sequence of the human $\delta$-globin gene. Ce1], $21: 639$, 1980.

23. Lawn, R.M., Efstratiadis, A., 0'Conne11, C.0., and Maniatis, T.: The nucleotide sequence of the human B-globin gene. Cel1, 21:647, 1980.

24. Efstratiadis, A., Posakony, J.W., Maniatis, T., Lawn, R.M., O'Connell, C., Spritz, R.A., deRiel, J.K., Forget, B.G., Weissman, S.M., Slightom, J.L., Blech1, A.E., Smithies, 0., Baralle, F.E., Shoulders, C.C., and Proudfoot, N.J.: The structure and evolution of the human B-globin gene family. Cel1, 21:653, 1980.

25. Kaufman, R.E., Knetschmer, P.J., Adams, J.W., Coon, H.C., Anderson, W.F., and Nienhuis, A.W.: Cloning and characterization of DNA

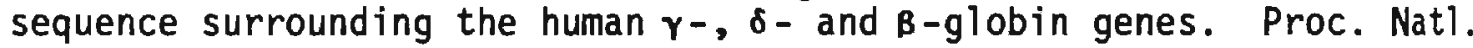
Acad. Sci. USA, $77: 4229,1980$.

26. Grosveld, F.G., Dah1, H.M., de Boer, E., and Flavel1, R.A.: Isolation of $\beta-g l o b i n$ related genes from a human cosmid library. Gene, 13:227, 1981.

27. Higgs, D.R., Vickers, M.A., Pretorius, I-M., Jarman, A.P., and Weatheral1, D.J.: A review of the molecular genetics of the human a-globin gene cluster. Blood, 73:1081, 1989.

28. Nienhuis, A.W. and Maniatis, T.: Structure and expression of globin genes in erythroid cells. In The Molecular Basis of Blood Diseases, edited by G. Stamatoyannopoulos, A.W. Nienhuis, P. Leder, and P.W. Majerus, page _, W.B. Saunders Company, Philadelphia, 1987.

29. Weatheral1, D.J., Wood, W.G., Jones, R.W., and Clegg, J.B.: The developmental genetics of human hemoglobin. In Progress in Clinical and Biological Research, Experimental Approaches for the Study of Hemoglobin Switching, edited by G. Stamatoyannopoulos and A.W. Nienhuis, Vol. 191, page 3, Alan R. Liss, Inc., New York, 1985. 
30. Nute, P.E., Pataryas, H.A., and Stamatoyannopoulos, G.: The $G_{\gamma}$ and $A_{\gamma}$ hemoglobin chains during human fetal development. Am. J. Hum. Genet., $35: 271,1973$.

31. Wilson, J.B. and Huisman, T.H.J.: Detection and quantitation of normal and abnormal hemoglobins in adults and newborn by high performance liquid chromatography. In The Hemoglobinopathies, edited by T.H.J. Huisman, Methods in Hematology, Vo1. 15, page 32, Churchill Livingstone, Edinburgh, 1986.

32. Huisman, T.H.J., Kutlar, F., and Gu, L-H.: Y Chain abnormalities and $\gamma$-globin gene rearrangements in newborn babies of various populations. Hemoglobin, 15:349, 1991.

33. Gilman, J.G. and Huisman, T.H.J.: DNA sequence variation associated with elevated fetal $G_{\gamma}$ globin production. Blood, 66:783, 1985.

34. Orkin, S.H.: Globin gene regulation and switching: Circa 1990. Cel1, 63:665, 1990.

35. van der Ploeg, L.H. and Flavell, R.A.: DNA methylation in the human $\gamma-, \delta-, \beta-g l o b i n$ locus in erythroid and nonerythroid tissues. Cell, $19: 947,1980$.

36. Felsenfeld, G.: Chromatin as an essential part of the transcriptional mechanism. Nature, 355:219, 1992.

37. Schaffner, W.: The role of cis- and trans-acting elements in the initiation of transcription. In Eucaryotic Transcription, edited by Y. Gluzman, 9th edition, Cold Spring Harbor Laboratory, Cold Spring Harbor, New York, 1985.

38. Charnay, P., Mellon, P., and Maniatis, T.: Linker scanning mutagenesis of the $5^{\prime}$ flanking region of the mouse $\beta$-major globin gene: Sequence requirements for transcription in erythroid and nonerythroid cells. Mol. Cell. Biol., 5:1498, 1985.

39. Dierks, P., van Ooyen, A., Cochran, M.D., Dobkin, C., Reiser, J., and Weissman, $C .:$ Three regions upstream from the Cap site are required for efficient and accurate transcription of the rabbit $\beta-g l o b i n g e n e$ in mouse 3 T6 cells. Ce11, 32:695, 1983.

40. Koury, G. and Gruss, P.: Enhancer elements. Cell, 33:313, 1983.

41. Gruss, P.: Review: Magic enhancers? DNA, 3:1, 1984.

42. Antoniou, M., de Boer, E., Habets, G., and Grosveld, F.: The human B-globin gene contains multiple regulatory regions: Identification of one promoter and two downstream enhancers. EMBO J., 7:377, 1988.

43. Purucker, M., Bodine, D., Lin, H., McDonagh, D., and Nienhuis, A.W.: Structure and function of the enhancer $3^{\prime}$ to the human $A_{\gamma}$ globin gene. Nucleic Acids Res., 18:7407, 1990.

44. Trudel, M. and Constantini, F.: A $3^{\prime}$ enhancer contributes to the stage-specific expression of the human B-globin gene. Genes. Develop., 1:954, 1987.

45. Raich, N., Papayarinopoulou, Th., Stamatoyannopoulos, G., and Enver, T.: Demonstration of a human $\varepsilon$-globin gene silencer with studies in transgenic mice. Blood, 79:861, 1992.

46. Berg, P.E., William, D.M., Qian, R-L., Cohen, R.B., Cao, S-X., Mittelman, M., and Schechter, A.N.: A common protein binds to two silencer $5^{\prime}$ to the human gene. Nucleic Acids Res., 17:8833, 1989.

47. Berg, P.E., Mittelman, M., Elion, J., Labie, D., and Schechter, A.N.: Increased protein binding to a -530 mutation of the human $B-g$ lobin gene associated with decreased B-globin synthesis. Am. J. Hematol., $36: 42,1991$. 
48. Elion, J., Berg, P., Lapoumeroulie, C., Trabuchet, G., Mittleman, M., Krishnamoorthy, R., Schechter, A.N., and Labie, D.: DNA sequence variation in a negative control region $5^{\prime}$ to the $B-g l o b i n$ gene correlates with the phenotypic expression of the SS mutation. Blood, $79: 787,1992$.

49. Semenza, G.L., Delgrosso, K., Poncz, M., Malladi, P., Schwartz, E., and Surrey, S.: B Thalassemia without a mutation in the B-globin gene or its immediate flanking regions. Cell, 39:123, 1984.

50. Murru, S., Loudianos, G., Cao, A., Vaccargiu, S., Pirastu, M., Sciarratta, G.V., Agosti, S., and Parodi, M.I.: A B thalassemia carrier with normal sequence within the $B$ globin gene. Blood, 76:2164, 1990 .

51. Tuan, D., Solomon, W., Li, Q., and London, I.: The B-like globin gene domain in erythroid cells. Proc. Nat1. Acad. Sci. USA, 82:6384, 1985.

52. Forrester, W., Thomson, C., Elder, J., and Groudine, M.: A developmentally stable chromatin structure in the human $B$ globin locus. Proc. Nat1. Acad. Sci. USA, 83:1359, 1986.

53. Koussis, D., Vanin, E., delange, T., Flave11, R.A., and Grosveld, F.G.: $B$ Globin gene inactivation by DNA translocation in $B$-thalassaemia. Nature, 306:662, 1983.

54. Driscol1, D., Dobkin, D., and Alter, B.: Y $\delta \beta$-Thalassemia due to a de novo mutation deleting the $5^{\prime}$ B-globin locus activating region hypersensitive sites. Proc. Nat1. Acad. Sci. USA, 86:7470, 1989.

55. Curtin, P., Pirastu, M., Kan, Y.W., Gobert-Jones, J.A., Stephens, A.D., and Lehmann, H.: A distant gene deletion affects $B$ globin gene function in an atypical $\gamma \delta B$-thalassemia. J. Clin. Invest., $76: 1554,1985$.

56. Ryan, T.M., Boehringer, R.R., Martin, N.C., Townes, T.M., Palmiter, R.D., and Brinster, R.L.: A single erythroid specific DNase I superhypersensitive site activates high levels of human $B$-globin gene expression in transgenic mice. Genes Develop., 3:314, 1989.

57. Forrester, W.C., Epner, E., Driscol1, M.C., Enver, T., Brice, M., Papayannopoulou, Th., and Groudine, M.: A deletion of the human Bglobin activating region causes a major alteration in chromatin structure and replication across the entire $\beta-g l o b i n$ locus. Genes Develop., 4:1637, 1990.

58. Fraser, P., Pruzina, S., Antoniou, M., and Grosveld, F.: Each hypersensitive site of the human B-globin locus control region confers a different developmental pattern of expression on the globin genes. Genes Develop., $7: 106,1993$.

59. Enver, T., Raich, N., Ebens, A.J., Papayannopoulou, Th., Costantini, F., and Stamatoyannopoulos, G.: Developmental regulation of human fetal to adult globin gene switching in transgenic mice. Nature, $344: 309$, 1990.

60. Boehringer, R.R., Ryan, T.M., Palmiter, R.D., Brinster, R.L., and Townes, T.M.: Human $r$ - to $B-g l o b i n$ gene switching in transgenic mice. Genes Develop., 4:380, 1990.

61. Philipsen, S., Talbot, D., Fraser, P., and Grosveld, F.: The B-globin dominant control region: Hypersensitive site 2. EMBO J., $9: 2159,1990$.

62. Talbot, D., Philipsen, S., Fraser, P., and Grosveld, F.: Detailed analysis of the site 3 region of the human $\beta-g l o b i n$ dominant control region. EMBO J., 9:2169, 1990. 
63. Pruzina, S., Hanscombe, 0., Whyatt, D., Grosveld, F., and Philipsen, S.: Hypersensitive site 4 of the human B-globin locus control region. Nucleic Acids Res., 19:1413, 1990.

64. Higgs, D.R., Goodbourn, S.E.Y., Wainscoat, J.S., Clegg, J.B., and Weatherall, D.J.: Highly variable regions of DNA flank the human a-globin gene. Nucleic Acids Res., 9:4213, 1981.

65. Kan, Y.W. and Dozy, A.M.: Polymorphism of DNA sequence adjacent to human $\beta$-globin structural gene: Relationship to sickle mutation. Proc. Nat7. Acad. Sci. USA, 75:5631, 1979.

66. Antonarakis, S.E., Boehm, C.D., Giardina, P.J.V., and Kazazian, H.H., Jr.: Nonrandom association of polymorphic restriction sites in the a-globin gene cluster. Proc. Natl. Acad. Sci. USA, 79:137, 1982.

67. Orkin, S.H., Kazazian, H.H., Jr., Antonarakis, S.E., Goff, S.C., Boehm, C.D., Sexton, J.P., Waber, P.G., and Giardina, P.J.V.: Linkage of $\beta$-thalassaemia mutations and $\beta$-globin gene polymorphisms with DNA polymorphisms in human B-globin gene cluster. Nature, 296:627, 1982.

68. Kazazian, H.H., Jr., Philips, J.A., III, Boehm, C.D., Vik, T.A., Mahoney, M.J., and Ritchey, A.K.: Prenatal diagnosis of $\boldsymbol{\beta}$-thalassemia by amniocentesis: Linkage analysis using multiple polymorphic restriction endonuclease sites. Blood, 56:926, 1980.

69. Antonarakis, S.E., Kazazian, H.H., Jr., and Orkin, S.H.: DNA polymorphisms and molecular pathology of the human globin gene clusters. Hum. Genet., 69:1, 1985.

70. Hill, A.V.S. and Wainscoat, J.S.: The evolution of the $\alpha-$ and $B-g 10-$ bin gene clusters in human populations. Hum. Genet., 74:16, 1986.

71. Pagnier, J., Mears, J.G., Dunda-Belkhodja, O., Schaefer-Rego, K.E., Beldjord, C., Nagel, R.L., and Labie, D.: Evidence for the multicentric origin of the sickle cell hemoglobin gene in Africa. Proc. Nat1. Acad. Sci. USA, 81:1771, 1984.

72. Antonarakis, S.E., Boehm, C.D., Serjeant, G.R., Theisen, C.E., Dover, G.J., and Kazazian, H.H., Jr.: Origin of the ${ }_{B} S$ globin gene in Blacks; the contribution of recurrent mutation or gene conversion or both. Proc. Natl. Acad. Sci. USA, 81:853, 1984.

73. Kulozik, A.E., Kar, B.C., Satapathy, R.K., Sariot, G.R., and Weathera11, D.J.: Fetal hemoglobin levels and $\beta S$ haplotypes in an Indian population with sickle cell disease. Blood, 69:1742, 1987.

74. Lapoumeroulie, C., Dunda, O., Trabuchet, G., Mony-Lobe, M., Labie, D., Elion, J., and Krishamoorthy, R.: A novel sickle gene of yet another origin in Africa; the Cameroon type. Blood, 74:63a (Supp1. 1), 1989.

75. Hattori, Y., Kutlar, F., Kutlar, A., McKie, V.C., and Huisman, T.H.J.: Haplotypes of ${ }_{B} S$ chromosomes among patients with sickle cell anemia from Georgia. Hemoglobin, 10:623, 1986.

76. Herrick, J.B.: Peculiar elongated and sickle-shaped red blood corpuscles. Arch. Intern. Med., 6:517, 1910.

77. Emmel, V.E.: A study of erythrocytes in a case of severe anemia with elongated and sickle shaped red blood corpuscles. Arch Intern. Med., 20:586, 1917.

78. Pauling, L., Itano, H.A., Singer, S.J., and Wells, I.C.: Sickle-cell anemia, a molecular disease. Science, 110:543, 1949.

79. Ingram, V.M.: A specific chemical difference between the globins of normal human and sickle cell anaemia haemoglobin. Nature, 178: $792,1956$. 
80. May, A. and Huehns, E.R.: The mechanism and prevention of sickling. Br. Med. Bull., 32:223, 1976.

81. Dean, J. and Schechter, A.N.: Sickle-cell anemia: Molecular and cellular bases of therapeutic approaches. (Three parts) N. Engl. J. Med., 299:752; 299:804; 299:863, 1979.

82. Nagel, R.L. and Ranney, H.M.: Genetic epidemiology of structural mutations of the B-globin gene. Semin. Hematol., 27:3429, 1990.

83. Adekile, A.D.: Anthropology of the $B S$ gene-flow from West Africa to North Africa, the Mediterranean, and Southern Europe. Hemoglobin, $16: 105,1992$.

84. Weathera11, D.J.: Common genetic disorders of the red cel1 and the malaria hypothesis. Ann. Trop. Med. Parasitol., 81:539, 1989.

85. Serjeant, G.R.: Sickle Cell Disease, Oxford University Press, Oxford, 1985.

86. Konotey-Ahulu, F.I.D.: Effect of environment on sickle cell disease in West Africa: Epidemiologic and clinical considerations. In Sickle Cell Disease, edited by H. Abramson, J. Bertles, and K.L. Wethers, C.V. Mosby, St. Louis, MO, 1973.

87. Akinyanju, 0.0.: Profile of sickle cell disease in Nigeria. Ann. N.Y. Acad. Sci., 565:126, 1979.

88. Embury, S.H.: a -Thalassemia. A modifier of sickle cell disease. Ann. N.Y. Acad. Sci., 565:213, 1989.

89. Adekile, A.D. and Huisman, T.H.J.: Hb F in sickle cell anemia. Experientia, in press.

90. Gupta, R.B., Tiwary, R.S., Pande, P.L., Kutlar, F., Oner, C., Oner, R., and Huisman, T.H.J.: Hemoglobinopathies among the Gond tribal groups of Central India: Interaction of $\alpha$ - and $\beta$-thalassemia with B chain variants. Hemoglobin, 15:441, 1991.

91. Fabry, M.E., Mears, J.G., Patel, P., Schaefer, K., Carmichael, L.D., Martinez, G., and Nagel, R.L.: Dense cells in sickle cell anemia The effects of gene interaction. Blood, 64:1042, 1984 .

92. Serjeant, G.R.: Fetal hemoglobin in homozygous sickle cell disease. Clin. Hema tol., 4:109, 1990.

93. Stivents, M.V., Hayes, R.J., Vaidaya, S., and Serjeant, G.R.: Fetal hemoglobin and clinical severity of homozygous sickle cell disease in early childhood. J. Pediatr., 98:37, 1981.

94. Powars, D.R., Weiss, J.N., Chan, L.S., and Schroeder, W.A.: Is there a threshold level of fetal hemoglobin that ameliorates morbidity in sickle cell anemia? Blood, 63:921, 1989.

95. Behe, M.J. and Englander, S.W.: Mixed gelation theory. Kinetics, equilibrium and gel incorporation in sickle hemogiobin mixtures. J. Mol, Biol., 133:137, 1979.

96. Benesch, R.E., Edalji, R., Benesch, R., and Kwong, S.: Solubilization of Hemoglobin $S$ by other hemoglobins. Proc. Natl. Acad. Sci. USA, $77: 5130,1980$.

97. Nage1, R.L., Bookchin, R.M., Johnson, J., Labie, D., Isaac-Sodeye, W.A., Honig, G.R., Schiliro, G., Crookston, J.H., and Matsumoto, K.: Structural bases of the inhibitory effects of Hemoglobin $F$ and Hemoglobin $A_{2}$ on the polymerization of Hemoglobin S. Proc. Nat1. Acad. Sci. USA,76:670, 1979 .

98. Hofrichter, J., Ross, P.D., and Eaton, W.A.: Kinetics and mechanism of deoxyhemoglobin $S$ gelation: A new approach to understanding of sickle cell disease. Proc. Nat1. Acad. Sci. USA, 71:4864, 1974. 
99. Sunshine, H.R., Hofrichter, J., and Eaton, W.A.: Gelation of sickle cell hemoglobin in mixtures with normal adult and fetal hemoglobins. J. Mol. Biol., 133:435, 1979.

100. Boyer, S.H., Belding, T.K., Margolte, L., and Noyes, A.N.: Fetal hemoglobin restriction to few erythrocytes ( $F$ cells) in normal human adults. Science, 188:361, 1975.

101. Dover, G.J., Boyer, S.H., Charache, S., and Heintzelamn, K.: Individual variation in the production and survival of $F$ cells in sickle-cell disease. N. Engl. J. Med., 299:1428, 1978.

102. Morris, J., Dunn, D., Beckford, M., Grandison, Y., Mason, K., Higgs, D.R., De Ceulear, K., Gerjeant, B.E., and Serjeant, G.R.: The haematology of homozygous sickle cell disease after the age of 40 years. Br. J. Haematol., $77: 382,1991$.

103. Miyoshi, K., Kaneto, Y., Kawai, H., Ohchi, H., N1ki, S., Hasagawa, K., Shirakami, A., and Yamano, T.: X-linked dominant control of $F$ cells in nomal adult life: Characterization of the Swiss type of hereditary persistence of fetal hemoglobin regulated dominantiy by gene(s) on X-chromosome. Blood, 72:1854, 1988.

104. Dover, G.J., Smith, K.D., Chang, Y.C., Purvis, S., Mays, A., Meyers, D.A., Sheils, C., and Serjeant, G.: Fetal hemoglobin levels in sickle cell disease and nomal individuals are partially controlled by an $X-1$ inked gene located at Xp22.2. Blood, 80:816, 1992.

105. Dover, G.J., Chang, V.T., Boyers, S.H., Serjeant, G.R., Antonarakis, S.E., and Higgs, D.R.: The cellular basis for different fetal hemoglobin levels among sickle cell individuals with two, three and four a-globin genes. Blood, 69:341, 1987.

106. Bakioglu, I., Hattori, Y., Kutlar, A., Mathew, C., and Huisman, T.H.J.: Five adults with mild sickle cell anemia share a ${ }_{B} \mathrm{~S}$ chromosome with the same haplotype. Am. J. Hematol., 20:297, 1985.

107. Kutlar, A., Hattori, Y., Bakioglu, I., Kutlar, F., Kamel, K., and Huisman, T.H.J.: Hematological observations on Arabian SS patients with a homozygosity or heterozygosity for a ${ }_{B} S$ chromosome with haplotype \#31. Hemoglobin, 9:545, 1985.

108. Miller, B.A., Salameh, M., Ahmed, M., 01ivieri, N., Antognetti, G., Orkin, S.H., Huisman, T.H.J., and Nathan, D.G.: Analysis of Hemoglobin $F$ production in Saudi-Arabian families with sickle cell anemia. Blood, 70:716, 1987 .

109. Nagel, R.L. and Labie, D.: DNA haplotypes and the ${ }_{B} S$ gene. In Progress in Clinical and Biological Research, Hemoglobin Switching, Part B: Cellular and Molecular Mechanisms, edited by G. Stamatoyannopoulos and A.W. Nienhuis, page 78, J. Wiley and Sons, New York, 1989.

110. Ballas, S.K., Talacki, A., Adachi, K., Schwartz, E., Surrey, S., and Rappaport, E.: The Xmn I site $(-158 \mathrm{C}+\mathrm{T}) 5^{\prime}$ to the $\mathrm{G}_{Y}$ gene: Correlation with the Senegalese haplotype and $G_{\gamma}$ globin expression. Hemoglobin, 15:407, 1991 .

111. Adams, J.G., III, Benjamin, L., Fryd, S., Gillette, P., Gilman, J., Hellman-Erlingsson, S., Hsu, H., Milner, P.F., Nagel, R.L., Rieder, R.F., Safaya, S., Steinberg, M.H., and Wrightstone, R.N.: Gender and haplotype effects upon hematological and clinical manifestations of sickle cell anemia. Clin. Res., 40:378, 1992. 
112. Ottolenghi, S., Mantovani, R., Nicolis, S., Ronchi, A., and Giglioni, B.: DNA sequences regulating human globin gene transcription in nondeletional hereditary persistence of fetal hemoglobin. Hemoglobin, $13: 523,1989$.

113. Miller, B.A., 01 ivieri, N., Salameh, M., Ahmed, M., Antognetti, G., Huisman, T.H.J., Nathan, D.G., and Orkin, S.H.: Molecular analysis of the high-Hemoglobin $F$ phenotype in Saudi Arabian sickle cell anemia. N. Engl. J. Med., 316:244, 1987.

114. Miller, B.A., Salameh, M., Ahmed, M., Olivieri, N., Huisman, T.H.J., Orkin, S.H., and Nathan, D.G.: Saudi Arabian sickle cell anemia; a molecular approach. Ann. N.Y. Acad. Sci., 565:143, 1989.

115. Bouhassira, E.E., Lachman, H., Krishnamoorthy, R., Labie, D., and Nagel, R.L.: A gene conversion located $5^{\prime}$ to the $A_{\gamma}$ gene in linkage disequilibrium with the Bantu haplotype in sickle cell anemia. $J$. Clin. Invest., 83:2070, 1989.

116. Bouhassira, E.E. and Nagel, R.L.: A 6-bp deletion $5^{\prime}$ to the $G_{y}$ globin gene in $\beta^{S}$ chromosomes bearing the Bantu haplotype. Am. J. Hum. Genet., $47: 161,1990$.

117. Month, S.R., Wood, R.W., Trifillis, P.T., Orchowski, P.J., Sharon, B., Ballas, S.K., Surrey, S., and Schwartz, E.: Analys is of the $5^{\prime}$ flanking regions of the $\boldsymbol{B}$ globin genes from major African haplotype backgrounds associated with sickle cell disease. J. Clin. Invest., $85: 364,1990$.

118. Beldjord, C., Ducrocq, R., Nadifi, S., Lapoumeroulie, C., Elion, J., and Labie, D.: A haplotype linked four base pair deletion upstream of the $A_{r}$ globin gene coincides with decreased gene epxression. Hum. Genet., 89:625, 1992.

119. Lanclos, K.D., Oner, C., Dimovski, A.J., Gu, Y-C., and Huisman, T.H.J.: Sequence variations in the $5^{\prime}$ flanking and IVS-II regions of the $G_{\gamma-\text { and }} A_{\gamma-g l o b i n}$ genes of $B S$ chromosomes with five different haplotypes. Blood, 77:2488, 1991.

120. Dimovski, A.J., Oner, C., Agarwa1, S., Gu, Y-C., Gu, L-H., Kutlar, F., Lanclos, K.D., and Huisman, T.H.J.: Certain mutations observed in the $5^{\prime}$ sequences of the ${ }^{G} \gamma$ and $A_{\gamma}$ globin genes of ${ }_{B} S$ chromosomes are specific for chromosomes with major haplotypes. Acta Haematol., $85: 79,1991$.

121. Oner, C., Dimovski, A.J., Altay, 6., Gurgey, A., Gu, Y-C., Huisman, T.H.J., and Lanclos, K.D.: Sequence variations in the $5^{\prime}$ hypersensitive site-2 of the locus control region of ${ }_{\beta} S$ chromosomes are associated with different levels of fetal hemoglobin in Hemoglobin S homozygotes. Blood, 79:813, 1992.

122. Adekile, A.D., Dimovski, A.J., Oner, C., Lanclos, K.D., and Huisman, T.H.J.: Haplotype-specific sequence variations in the locus control region ( $5^{\prime}$ hypersensitive sites $2,3,4$ ) of ${ }_{\beta} S$ chromosomes. Hemoglobin, in press.

123. Oner, C., Dimovski, A.J., 0livieri, N.F., Schiliro, G., Codrington, J.F., Fattoum, S., Adekile, A.D., Oner, R., Yuregir, G.T., Altay, 6., Gurgey, A., Gupta, R.B., Jogessar, V.B., Kitundu, M.N., Loukopoulos, D., Tamagnini, G.P., Ribeiro, M.L.S., Kutlar, F., Gu, L-H., Lanclos, K.D., and Huisman, T.H.J.: $B$ S Haplotypes in various world populations. Hum. Genet., 89:99, 1992.

124. Weatherall, D.J. and Clegg, J.B.: The Thalassaemia Syndromes, 3rd edition, Blackwell Scientific Publications, Oxford, 1981. 
125. Steinberg, M.H. and Adams, J.G., III: Hemoglobin $A_{2}$ : Origin, evolution, and aftermath. Blood, 78:2165, 1991.

126. Piomelli, S.: Management of thalassemia major (Cooley's anemia). In Current Views on Thalassaemia, With Special Reference to Its Mediterranean Presence, edited by S. Roath and T.H.J. Huisman, page 137, Harwood Academic Publishers, Chur, Switzerland, 1992.

127. Lucarelli, G., Galamberti, P., Polchi, E., Angelucci, D., Baronciani, C., Giardini, C., Politi, P., Durazzi, S.M.T., Muretto, P., and Albertini, F.: Bone marrow transplantatioin in patients with thalassemia. N. Engl. J. Med., 322:417, 1990.

128. Aksoy, M. and Erdem, S.: Some problems of hemoglobin pattern in different thalassemia syndromes showing the heterogeneity of $\beta$-thalassemic genes. Ann. N.Y. Acad. Sci., 165:13, 1969.

129. Saiki, R.K., Scharf, S., Faloona, F., Mullis, K.B., Horn, G.T., Erlich, H.A., and Arnheim, N.: Enzymatic amplification of $\beta$-globin genomic sequences and restriction site analysis for diagnosis of sickle cell anemia. Science, 230:1350, 1985.

130. The $\beta$ - and $\delta$-thalassemia repository. Hemoglobin, 16:237, 1992.

131. Mitchener, J.W., Thompson, R.B., and Huisman, T.H.J.: Foetal haemoglobin synthesis in some haemoglobinopathies. The Lancet, $i: 1169$, 1961 .

132. Loukopoulos, D. and Fessas, Ph.: The distribution of hemoglobin types in thalassenic erythrocytes. J. Clin. Invest., 44:231, 1965.

133. Weatherall, D.J., Clegg, J.B., and Wood, W.G.: A model for the persistence or reactivation of foetal haemoglobin production. The Lancet, ii:660, 1976.

134. Labie, D., Pagnier, J., Lapoumeroulie, C., Rouabbi, F., Dunda-Belkhodja, O., Chardin, P., Beldjord, C., Wajcman, H., Fabry, M.E., and Nagel, R.L.: Common haplotype dependency of high Gr-globin gene expression and high $H b F$ levels in $B$-thalassemia and sickle cell aremia. Proc. Nat1. Acad. Sci. USA, 71:248, 1988.

135. Diaz-Chico, J.C., Yang, K.G., Stoming, T.A., Efremov, D.G., Kutlar, A., Kutlar, F., Aksoy, M., Altay, 6., Gurgey, A., Kilinc, Y., and Huisman, T.H.J.: Mild and severe B-thalassemia among homozygotes from Turkey: Identification of the types by hybridization of amp 71 fied DNA with synthetic probes. Blood, 71:248, 1988.

136. Galanel10, R., Dessi, M.A., Melis, M.A., Sanna, A., Rosatelli, C., Argiolu, F., Giagu, N., Turco, M.P., Cacace, E., Pirastu, M., and Cao, A.: Molecular analysis of $\beta^{\circ}$-thalassemia intermedia in Sardinia. Blood, 74:823, 1989.

137. Gonzalez-Redondo, J.M., Stoming, T.A., Lanclos, K.D., Gu, Y.C., Kutlar, A., Kutlar, F., Nakatsuji, T., Deng, B., Han, I.S., McKie, V.C., and Huisman, T.H.J.: Clinical and genetic heterogeneity in Black patients with homozygous B-thalassemia from the Southeastern United States. Blood, 72:1007, 1988.

138. Ottolenghi, S., Giglioni, B., Pulzini, A., Comi, P., Camaschella, C., Serra, A., Guerrasio, A., and Saglio, G.: Sardinian $\delta \beta^{\circ}$-thalassemia; a further example of a $C->T$ substitution at position -196 of

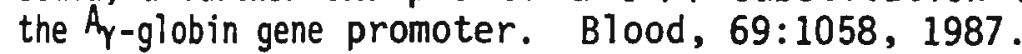

139. Ragusa, A., Lombardo, M., Beldjord, C., Ruberto, C., Lombardo, T., Elion, J., Nagel, R.L., and Krishnamoorthy, R.: Genetic epidemiology of $\beta$-thalassemia in Sicily: Do sequences $5^{\prime}$ to the $G_{\gamma}$ gene and $5^{\prime}$ to the $B$ gene interact to enhance $H b F$ expression in $B$-thalassemia? Am. J. Hematol., 40:199, 1992. 
140. Beaven, G.H., Ellis, M.J., and White, J.C.: Studies on human foetal haemoglobin. I. Detection and estimation. Br. J. Haematol., 6:1, 1960.

141. Beaven, G.H., Ellis, M.J., and White, J.C.: Studies on human foetal haemoglobin. II. Foetal haemoglobin levels in healthy children and adults and in certain haematological disorders. Br. J. Haenatol., $6: 201,1960$.

142. Beaven, G.H., Ellis, M.J., and White, J.C.: Studies on human foetal haemoglobin. III. The hereditary haemoglobinopathies and thalassaemias. Br. J. Haematol., 7:159, 1961.

143. Kutlar, A., Kutlar, F., Gu, L-G, Mayson, S.M., and Huisman, T.H.J.: Fetal hemoglobin in normal adults and B-thalassemia heterozygotes. Hum. Genet., 85:106, 1990.

144. Dimovski, A.J., Efremov, D.G., Jankovic, L., Plaseska, D., Juricic, D., and Efremov, G.D.: A $B^{\circ}$-thalassaemia due to a 1605 bp deletion of the 5' B-globin gene region. $\mathrm{Br}$. J. Haematol., in press. 


\section{CHAPTER 2}

MATERIALS AND METHODS 



\section{CHAPTER 2}

1. Materials and Methods. This chapter provides detailed information about the procedures used in the analyses of the blood samples. The basic principles of the DNA methods are reviewed, while the details of the DNA methodology are given in Chapters 3 and 4.

2. Patients. As many as 709 adults with SS, 57 newborn SS patients, and 50 B-thal major patients originating from 16 different countries have been studied (Table 2/1). Also included are data about 478 individuals with AS, Hb S-B-thal, SC, AC, B-thal trait, and 31 normal adults. Many of these persons have been studied previously and several DNA samples were available $(1-4)$. However, it was often necessary to recollect blood for DNA extraction and/or reevaluation of the $\mathrm{Hb}$ composition and hematological data. Although the initial diagnoses of the patients were made in the participating foreign institutions, hematological and Hb composition data have also been collected in the laboratory in Augusta, GA, USA. Details of studies done in particular groups of patients are presented in Chapters 3 and 4.

TABLE 2/1. The Origin of the Patients Participating in the Studya

\begin{tabular}{lrrrrrrrr}
\hline Country & SS & SC & AS & SB & BB & AB & AA & Total \\
\hline SE USA & 147 & 13 & 41 & 23 & 7 & 30 & 30 & 291 \\
Canada & 21 & 11 & 5 & 3 & - & - & - & 40 \\
Surinam & 14 & 1 & 45 & 3 & - & - & - & 63 \\
Kenya & 55 & - & 1 & 0 & - & - & - & 56 \\
Tanzania & 14 & - & 13 & - & - & - & - & 27 \\
Nigeria & 294 & 2 & 30 & 3 & - & - & - & 329 \\
Angolab & 6 & - & 4 & - & - & - & - & 10 \\
Tunisia & 35 & 2 & 37 & 6 & - & - & - & 80 \\
Sicily (Italy) & 18 & - & 19 & 15 & - & - & - & 52 \\
Greece & - & - & 14 & - & - & - & - & 14 \\
Turkey & 67 & 1 & 60 & 19 & 26 & - & - & 153 \\
Syria & 2 & - & 5 & 4 & - & - & - & 11 \\
India & 36 & - & 45 & 12 & - & - & - & 93 \\
South Africa (Indians) & - & - & 3 & 3 & - & - & - & 6 \\
Portugal & - & - & - & - & 11 & - & - & 11 \\
Macedonia & - & - & - & - & 5 & - & - & 5 \\
Croatia & - & - & - & - & - & 2 & - & 2 \\
Switzerland & - & - & - & - & 1 & 3 & 1 & 5 \\
Czechoslovakia & - & - & - & - & - & - & 6 & 6 \\
Hungary & - & - & - & - & 2 & - & - & 2 \\
\hline ToTAL & 709 & 30 & 322 & 91 & 52 & 35 & 37 & 1276 \\
\hline
\end{tabular}

a Adapted from Oner et al (5).

b From subjects living in Portugal. 
3. Blood Collection/Shipment. Blood samples were collected in vacutainers (Beckton Dickinson Vacutainer Systems, New Jersey, N.J., USA) with EDTA as anticoagulant. The samples were kept cold $\left(4^{\circ} \mathrm{C}\right)$ until the time of shipment. Some samples reached the laboratory in Augusta, GA, USA, more than 3 weeks after collection. All samples obtained overseas were transported in wet ice by air and were usually received within 4 days after shipment.

4. Hb and Hematological Analysis. The procedures are listed in sequence, similar to that used during the routine processing of blood samples in the laboratory in Augusta, GA, USA.

4/a Hematological Data. Hematological values were obtained with a fully automated cell counter (Sysmex CC-620, Toa Medical Electronics Co., Kobe, Japan). The RBC indices, MCV (in f1), and MCH (in pg), were calculated from the values of total Hb concentration $(\mathrm{g} / \mathrm{dl})$, PCV (in $1 / 1)$, and $\mathrm{RBC}$ count $\left(x 10^{12} / 1\right)$. The MCV and MCH values are useful parameters for the assessment of the possible presence of thalassemia and certain $\mathrm{Hb}$ variants, particularly when the $\mathrm{MCV}$ values are below $80 \mathrm{fl}$ and the $\mathrm{MCH}$ values are below $27 \mathrm{pg}$. The higher MCV values obtained in some of the samples are most probably due to prolonged and/or inappropriate storage before analysis. It is worth noting that the $\mathrm{MCH}$ values can also be influenced by a number of acquired conditions such as iron deficiency and a variety of other uncommon hematological abnormalities.

4/b Hb Analyses. Red blood cells were washed three times with isotonic saline and hemolyzed with 1.5 volumes of water and 0.4 times the volume of $\mathrm{CCl}_{4}$ for 15 minutes at room temperature with occasional stirring. Stroma was removed by centrifugation at $20,000 \mathrm{~g}$ at $4^{\circ} \mathrm{C}$ for 20 minutes. These hemolysates were used for electrophoretic and chromatographic analyses.

i. IEF. The IEF analysis was performed for initial Hb identification using commercially available agarose gels and buffers (Isolab, Inc., Akron, $\mathrm{OH}$, USA). Agarose offers a high gel strength with sufficient porosity to allow migration of proteins with molecular weights of up to $10^{6}$ daltons. The analysis is sensitive enough to separate $\mathrm{Hb}$ variant whose $\mathrm{pIs}$ differ by 0.02 or greater (6). Usualiy, $6 \mu 1$ of hemolysate was applied on a gel and electrophoresis was performed for 2 hours at 30W constant power using an LKB Multiphor II Horizontal Unit (Pharmacia LKB, Uppsala, Sweden). When all $\mathrm{Hbs}$ focused at their respective $\mathrm{PI}$, the gel was fixed for about 2 hours in $10 \%$ trichloroacetic acid for 10 minutes and the bands were visualized with an heme specific dye (o-dianisidine) and $\mathrm{H}_{2} \mathrm{O}_{2}$. Band identification was by comparing the distances of migration to control samples containing the known $\mathrm{Hb}$ types of $A, F, S, C$, and Bart's (Fig. 2/1).

ii. Fetal Hb Quantitation. The quantitation of $H b F$ was by alkali denaturation (7) and/or by two recently developed HPLC procedures (11-14).

iii. Alkali Denaturation Method. The alkali denaturation method is still the most popular and simple method which is based on the higher resistance of $H b F$ to denaturation in alkali. It was described by Betke 
et al (7) but there are several published variations of the test $(8-10)$. The one used in this study involves the conversion of cyanmetib before denaturation which prevents false-positives, particularly in patients with increased concentrations of the alkali-resistant $\mathrm{CO}-\mathrm{Hb}$, e.g. in heavy smokers. This method offers a reasonable accuracy for the $\mathrm{Hb} F$ concentrations between $5-20 \%$. The disadvantage is that the $H b F$ levels below $5 \%$ are determined too high and the $\mathrm{Hb} \mathrm{F}$ levels above $20 \%$ are determined too low (11).

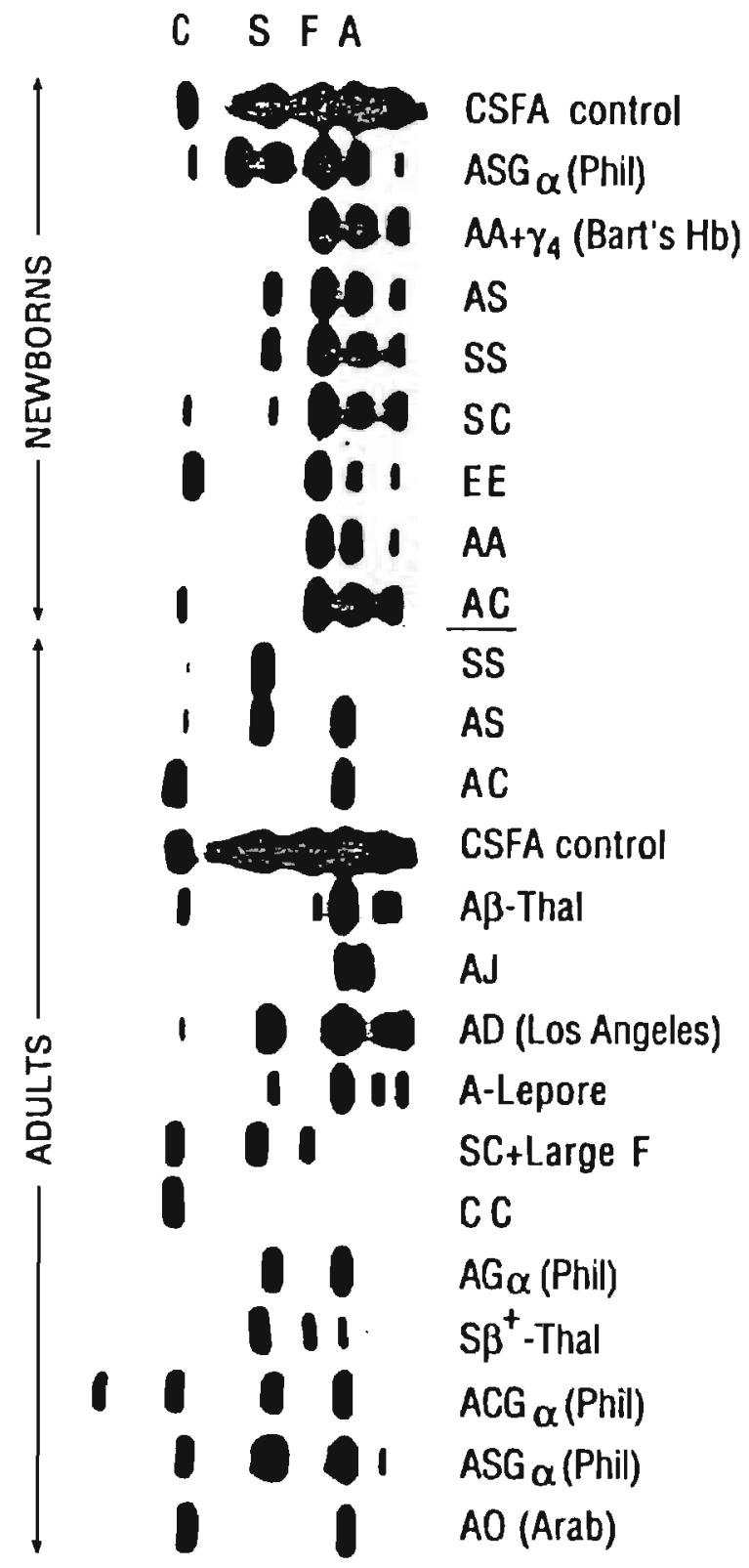

FI6. 2/1. IEF analyses of red cell lysates from eight newborns and 14 adults with various hemoglobinopathies. Hb components with similar isoelectric points (Hbs $0, E, C$ ) were characterized by citrate agar electrophoresis or by cation exchange HPLC. 
4/c HPLC Procedures. The two recently described HPLC methods offer higher accuracy in the determination of the levels of $\mathrm{Hb} F$. The first uses a weak cation exchange resin that allows complete separation of $\mathrm{Hb} F$ (as $H b F_{0}$ and $H b F_{1}$ ) from other $H b$ types in less than 50 minutes $(11,12$ ). The second is a reversed phase HPLC method which allows the separation of heme and various globin chains $(13,14)$.

i. Cation Exchange HPLC. Quantitation of $H b F$ was performed on a polyCAT A cation exchange column $(4.6 \times 200 \mathrm{~mm}$, with a particle size of $5 \mu \mathrm{m}$; PolyLC, Columbia, MD, USA) using a Waters HPLC System (Waters Chromatography Division, Milford, MA, USA). The developers used are as follows: Developer A: $35 \mathrm{mM}$ Bis-Tris, $3 \mathrm{mM} \mathrm{NH} 4$-acetate, $1.5 \mathrm{mM} \mathrm{KCN}, \mathrm{pH} 6.47$; developer B: $35 \mathrm{mM}$ Bis-Tris, $1.5 \mathrm{mM} \mathrm{KCN} 150 \mathrm{mM}$ Na-acetate, $16.85 \mathrm{mM} \mathrm{NH}_{4}$-acetate, $\mathrm{pH} 7.0$. The column is initially purged for 5 minutes with 100\% developer B and equilibrated with $25 \%$ developer B for 10 minutes. Some $50-200 \mu \mathrm{g}$ of $\mathrm{Hb}(10-15 \mu \mathrm{l}$ hemolysate) is applied to the column and the chromatogram is developed with a gradient of $25 \%$ developer $B$ to $85 \%$ developer B in 85 minutes with a flow-rate of $0.8 \mathrm{ml} / \mathrm{min}$. The absorbance of the efluent is continuously recorded at $415 \mathrm{~nm}$ with a chart speed of 0.25 $\mathrm{cm} / \mathrm{min}$. The order of elution of different types of $\mathrm{Hbs}$ is $F, A, A_{2}, S$, and $C$, which are readily separated from each other and accurately quantitated. A disadvantage is the minor contamination of $\mathrm{Hb} \mathrm{A}_{2}$ with $\mathrm{Hb} \mathrm{S}_{1}$ which results in slightly higher $\mathrm{Hb} A_{2}$ values in the presence of $\mathrm{Hb} S$ (Fig. 2/2).

ii. Reversed Phase HPLC. A large-pore Vydac $C_{4}$ column (Vydac, Hesperia, CA, USA) and two water-acetonitrile-TFA developers are used for the separation of globin chains as originally described by Shelton et al (13) and Kutlar et al (14). Developer A is $60 \%$ acetonitrile, $0.1 \%$ TFA, $40 \%$ water, and developer $B$ is $20 \%$ acetonitrile, $0.1 \%$ TFA, $80 \%$ water. The column is initially purged with $100 \%$ developer $A$ and equilibrated for 10 minutes with 50\% developer $A$ and $50 \%$ developer $B$. Some 50-800 $\mu \mathrm{g} \mathrm{Hb}$ in red cell lysates is applied to the column and the chromatogram is developed in a gradient of $50 \%$ developer $A$ to $60 \%$ developer $A$ in 70 minutes at a flow-rate of $1 \mathrm{ml} / \mathrm{min}$. The absorbance of the efluent is continuously recorded at $215 \mathrm{~nm}$ and peaks are quantitated (as area \%) by a data module. The separation of the globin chains by this method depends primarily on differences in their hydrophobicities. As a general rule the more polar (less hydrophobic) chains elute earlier in the chromatogram (13). The presence of TFA in the developer results in a low pH of 2 which causes the dissociation of the Hbs in heme and the chains. The order of elution of the different $H b$ chains is $\beta^{C}, \beta S, \beta A, \delta, \alpha, A_{\gamma} T, G_{Y}$, and $A_{Y} I$. The levels of $H b F\left(=G_{Y}+A_{Y} I+A_{Y}^{T}\right)$ are calculated as \% of total $B-1 i k e$ chains $\left(\delta+B+A_{\gamma}^{T}+G_{Y}+A_{Y}\right)$. Slightly higher values of $H b F$ obtained by this method are perhaps due to some contamination of $G_{Y}$ with a chains (14) (Fig. 2/2).

iii. Hb F Composition Analysis. The chain composition of $H b F$ was studied by the reversed phase HPLC method (14) described above and also by the visual inspection of polyacrylamide gels (16). Samples that contain less than $20 \%$ of $\mathrm{Hb} \mathrm{F}$ in their red cell lysates (as estimated by IEF) require an initial enrichment of the $\mathrm{Hb} F$ fraction, which was performed by anion exchange DEAE-cellulose chromatography (17). The resin is equilibrated with repeated washings with a $0.2 \mathrm{M}$ glycine, $15 \mathrm{mM} \mathrm{KCN}$ buffer, $\mathrm{pH}$ 
7.5, and the chromatogram was developed using a $0.2 \mathrm{M}$ glycine, $0.01 \% \mathrm{KCN}$, $0.02 \mathrm{M} \mathrm{NaCl}$ developer. Depending upon the $\%$ of $\mathrm{Hb} \mathrm{F}$ present in the red cell lysate, 20-60 mg $\mathrm{Hb}$ in the hemolysate are applied to a column (30 X $1.5 \mathrm{~cm})$; the chromatogram is developed for 15 hours at a flowrate of $50 \mathrm{ml} /$ hour. The Hb F fraction located at the top is cut from the column, poured into a microcolumn $(7 \times 0.5 \mathrm{~cm})$ and eluted with a stripping buffer $(0.01 \%$ $\mathrm{KCN}, 0.2 \mathrm{M} \mathrm{NaCl}, 0.2 \mathrm{M}$ glycine).

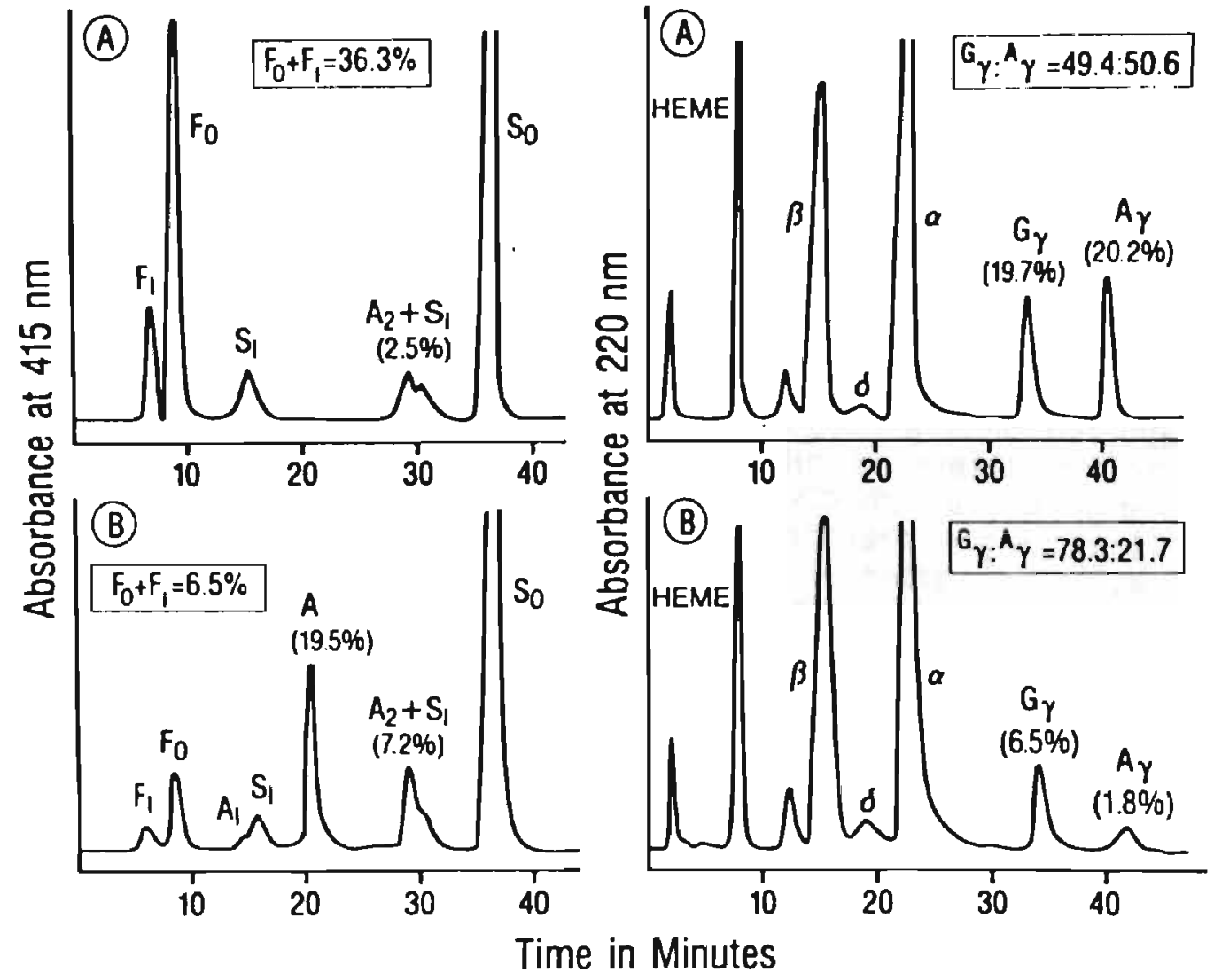

FIG. 2/2. Quantitation of $H b F$ and the relative amount of the $G_{Y}$ and $A_{Y}$ chains in Hb F by HPLC procedures. A : A young SS patient with a high level of $\mathrm{Hb} F$ that was estimated at $36.3 \%\left(F_{0}+F_{1}\right)$ by cation exchange HPLC $(11,12)$ and at $39.9 \%\left(G_{\gamma}\right.$ and $A_{\gamma}$ as \% of $B+\delta+G_{\gamma}$ and $\left.A_{\gamma}\right)$ by reversed phase HPLC $(13,14)$. Higher values of $H b F$ by reversed phase HPLC are probably due to slight contamination of $G_{\gamma}$ with $a$. The nearly identical percentage of $G_{Y}$ and $A_{\gamma}$ in this young patient suggests that the switching from the newborn ratio $(70: 30)$ to the so-called adult ratio $(40: 60)$ is in progress. B : Similar data for

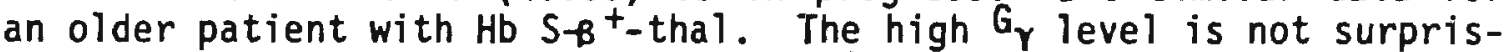
ing because the two most common $B l a c k B^{+}$-thal mutations are associated with high $G_{Y}$ values (15).

iv. Hb $F$ Composition Analysis by PAGE. This analysis was performed for the two patients with the Croatian deletion in the laboratory in Skopje, Macedonia, following the procedure of Alter et al (16). Hb F was isolated by DEAE-cellulose chromatography (14) as described previously. The electrophoresis was performed on a $12 \%$ polyacrylamide gel containing 
$6 \mathrm{M}$ urea and $2 \%$ Triton $X-100$ in $5 \%$ acetic acid, which was also used as an electrophoresis buffer. After casting the gel, the pre-electrophoresis was done for 60 minutes at $200 \mathrm{~V}$ with the anode at the top. Next, the anodal buffer was removed, the gels were overlaid with $1 \mathrm{M}$ cysteamine (Aldrich Chemical Co. Inc., Milwaukee, WI, USA), and a second pre-electrophoresis was performed for 45-60 minutes at $150 \mathrm{~V}$. The cysteamine was removed entirely by flushing the wells with $5 \%$ acetic acid. Five-to-ten $\mu \mathrm{g}$ of $\mathrm{Hb}$ was mixed with freshly prepared loading buffer $(5 \mathrm{ml} 8 \mathrm{M}$ urea, $0.5 \mathrm{ml}$ glacial acetic acid, $0.5 \mathrm{ml}$ of 2-mercaptoethanol, and $2 \mathrm{mg}$ of pyronin $Y$ ) and applied to the ge1. Electrophoresis was for 17 hours at $8.5 \mathrm{~mA}$ constant current at $4^{\circ} \mathrm{C}$. Following electrophoresis, the gels were stained for 30 minutes in $0.5 \%$ Coomassie Brilliant Blue dissolved in $7 \%$ acetic acid with $30 \%$ methanol, and destained in the acid-methanol solution by diffusion overnight. The $G_{Y} /{ }^{A} Y$ was estimated by visual inspection.

v. Quantitation of $\mathrm{Hb} \mathrm{A}_{2}$. In several instances the $\mathrm{Hb}_{2} \mathrm{~A}_{2}$ level was determined by anion exchange DEAE-cellulose chromatography using the QuickSep $\mathrm{Hb} \mathrm{A}_{2}$ Test System (Isolab, Inc., Akron, OH, USA). Some 5-10 11 l hemolysate are applied onto a column and the $\mathrm{Hb} \mathrm{A}_{2}$ is eluted from the column under specific conditions of $\mathrm{pH}$ and chloride ion concentration (Developer $A$ : $0.2 \mathrm{M}$ glycine, $0.01 \% \mathrm{KCN}$ ). All the remaining Hbs are eluted from the column as a single fraction with developer $B(0.2 \mathrm{M}$ glycine, $0.01 \%$ $\mathrm{KCN}, 0.2 \mathrm{M} \mathrm{NaCl})$. Absorbance values of the two fractions are measured at $415 \mathrm{~nm}$. The disadvantage of the method is that $\mathrm{Hb} \mathrm{E}$ and $\mathrm{Hb} \mathrm{C}$ co-elute with $\mathrm{Hb} \mathrm{A}_{2}$.

\section{DNA Analyses}

5/a Isolation of Human Genomic DNA From Whole Blood. DNA is isolated from the white blood cells using the method of Poncz et al (18). About $5-10 \mathrm{ml}$ whole blood is washed twice with $40 \mathrm{ml} 1 \times$ reticulocyte saline $(140 \mathrm{mM} \mathrm{NaCl}, 4 \mathrm{mM} \mathrm{KCl}, 6.8 \mathrm{mM} \mathrm{MgCl} 2)$ and the cells are pelleted by centrifugation at $2500 \mathrm{~g}$ for 10 minutes at $4^{\circ} \mathrm{C}$. The red blood cells are next hemolyzed with $20 \mathrm{ml}$ of freshly prepared lysing buffer (131 $\mathrm{mM} \mathrm{NH} \mathrm{NH}_{4} \mathrm{Cl}, 0.9$ $\left.\mathrm{mM}\left(\mathrm{NH}_{4}\right)_{2} \mathrm{CO}_{3}, \mathrm{pH} 6.5\right)$ at room temperature for 20 minutes with occasional shaking. After centrifugation at $2500 \mathrm{~g}$ and at $4^{\circ} \mathrm{C}$, the supernatant (hemolysate) is collected and stored at $-20^{\circ} \mathrm{C}$ for $\mathrm{Hb}$ analysis. The lysing procedure is repeated once more, and the pellet consisting mainly of white blood cells is resuspended in $10 \mathrm{ml}$ of STE buffer $(0.1 \mathrm{M} \mathrm{NaCl}, 0.05 \mathrm{M}$ Tris$\mathrm{HCl}, \mathrm{pH} 7.4,1 \mathrm{mM}$ EDTA), $1 \mathrm{ml}$ of $10 \% \mathrm{SDS}$ and $0.1 \mathrm{ml}$ of proteinase $\mathrm{K}$ (10 mg/ $\mathrm{ml}$ in $10 \mathrm{mM}$ Tris- $\mathrm{HCl}, \mathrm{pH} 7.5,1 \mathrm{mM}$ EDTA) and incubated overnight at $37^{\circ} \mathrm{C}$ without shaking. Deproteinization is accomplished by phenol/chloroform/ isoamyl alcohol extractions as follows: One volume of phenol, saturated with $20 \mathrm{mM}$ Tris, $\mathrm{pH} 8.0$, containing $0.1 \%$ hydroxyquinoline is added to the viscous solution, and the mixture is gently shaken for 30 minutes at room temperature. After centrifugation at $2500 \mathrm{~g}$ and at $4^{\circ} \mathrm{C}$, the upper aqueous phase is transferred to a second tube and the procedures are repeated. An equal volume of chloroform/isoamyl alcohol (19:1 by vol/vol) is added and the mixture is shaken gently for 10 minutes at room temperature. After centrifugation for 10 minutes at $4^{\circ} \mathrm{C}$ the upper aqueous phase is transferred to a fresh tube and the DNA is precipitated with 5 volumes of ice-cold 
absolute ethanol. The DNA precipitate is transferred to a $1.5 \mathrm{ml}$ Eppendorf tube with a sterile Pasteur pipette, washed twice with $70 \%$ ethanol, dried under vacuum and dissolved by incubation in $1 \mathrm{ml}$ of TE buffer ( $10 \mathrm{mM}$ Tris$\mathrm{HCl}, \mathrm{pH} 7.5,1 \mathrm{mM}$ EDTA) overnight at $37^{\circ} \mathrm{C}$. The concentration of the DNA is determined from its extinction coefficient at $260 \mathrm{~nm}(10 D=50 \mu \mathrm{g} / \mathrm{m} 1$ DNA). The DNA is stored at $4^{\circ} \mathrm{C}$.

5/b Gene Mapping. The gene mapping analyses are performed by the modified procedure of Southern (20) for the evaluation of the a-globin genes, for the determination of the B-globin gene cluster haplotypes, and for the mapping of the breakpoints of a few deletions in the $B$ cluster (Chapters 3 and 4 ). The enzymes and probes used for these applications are listed in Chapters 3 and 4.

i. Genomic DNA Digestion, Electrophoresis, and Southern Blot. Five micrograms of genomic DNA is digested with a restriction enzyme for 6 hours at $37^{\circ} \mathrm{C}$ in a buffer supplied by the manufacturer. The resulting DNA fragments and $\lambda$-DNA digested with Hind III as a size marker are separated overnight by electrophoresis on a $0.8 \%$ agarose gel in a horizontal electrophoresis chamber (Bio-Rad DNA Sub Ce11; Bio-Rad Laboratories, Richmond, CA, USA) at 25-30 volts constant voltage at room temperature. TEA buffer (0.04 M Tris-acetate, 0.001 M EDTA, pH 8.3) is used for both agarose preparation and electrophoresis. Following electrophoresis, the DNA in the gel is stained with ethidium bronide $(0.5 \mathrm{mg} / \mathrm{ml})$ and the gel is photographed under long wavelength UV light. The DNA is depurinated by soaking the gel for 30 minutes in $0.1 \mathrm{~N} \mathrm{HCl}$, denatured for 60 minutes in a neutralization solution ( $3 \mathrm{M} \mathrm{NaCl}, 1.5 \mathrm{M}$ Tris-HCl, $\mathrm{pH} 7.0)$. All three procedures are performed at room temperature with gentle shaking. The capillary transfer of the DNA to either a nitrocellulose (Trans-Blot Transfer Membrane; Bio-Rad) or a nylon (Hybond C Membrane; Amersham International, Amersham, Bucks, England) membrane is done with a $20 \times$ SSC solution $(0.3 \mathrm{M}$ Na-citrate, $3 \mathrm{M} \mathrm{NaCl}, \mathrm{pH} 7.0$ ) for the period of 16-24 hours. Following the transfer, the membrane is baked in a vacuum oven for 2 hours at $70-$ $80^{\circ} \mathrm{C}$, wrapped in plastic film, and finally stored at $4^{\circ} \mathrm{C}$.

ii. Prehybridization. The membrane is wetted in a baking dish with $6 \times$ SSC + Denhardt's solution [0.5\% SDS, $0.02 \%$ BSA, $0.02 \%$ Ficoll $400,0.02 \%$ PVP, $0.09 \mathrm{M} \mathrm{Na}$-citrate, $\mathrm{pH} 7.0$, and $0.9 \mathrm{M} \mathrm{NaCl}$ ] and prehybridized for 1 to 3 hours at $65^{\circ} \mathrm{C}$ in a sealed plastic bag with 15 to $20 \mathrm{ml}$ of $1 \times$ Flavell modified solution ( $3 \times$ SSC, $0.1 \%$ SDS, $0.2 \%$ BSA, $0.2 \%$ PVP, 0.02 M phosphate buffer, $\mathrm{pH} \mathrm{6.0)}$ and $50 \mu \mathrm{g} / \mathrm{ml}$ denatured salmon sperm DNA.

iii. Hybridization. In general $10-15 \times 10^{6} \mathrm{cpm}$ of a-32p-labeled probe (see $2 / 5$ ) is used for hybridization. The probes were denatured in a boiling water-bath for 10 minutes prior to being added to the prehybridization solution. The hybridization is at $65^{\circ} \mathrm{C}$ overnight (at least 16 hours).

iv. Membrane Washing and Autoradiography. The membranes are washed in $3 \times$ SSC, $0.5 \%$ SDS solution at $65^{\circ} \mathrm{C}$ for at least 60 minutes $(3 \times 20$ minute changes) in a circulating water-bath. The radioactivity of the membrane is monitored with a Geiger counter, and the washing is stopped when 
only a few counts above background are counted. The membrane is blotted dry, wrapped in plastic film and exposed to a Kodak XAR X-ray film (Eastman Kodak Company, Rochester, N.Y., USA) with DuPont Quanta II intensifying screens (DuPont, Boston, MA, USA) for at least 3 days. Films are developed with a Kodak X-ray film processor (X-Omat M20 Processor, Eastman Kodak).

v. Probes. The probes used in this study are different fragments of the $\beta-$ and a-globin gene clusters, previously cloned in plasmid vectors (pUC 19 or PBR 322). Prior to radioactive labeling, the probes are isolated from the plasmids by the following procedure: 20-30 $\mathrm{\mu g}$ of plasmid DNA is digested with 1-2 $\mathrm{J} / \mu \mathrm{g}$ of an appropriate restriction enzyme(s) for 1 hour at $37^{\circ} \mathrm{C}$, followed by electrophoresis in a $1 \%$ agarose gel; the band corresponding to the probe of interest is sliced out from the gel and the DNA is eluted with a Gene Clean Kit (Bio 101; Bio-Rad) under the conditions recommended by the manufacturer.

The following probes were used in the study: a) The $\gamma$ IVS-II probe; a 457 bp Bam HI/Pvu II fragment of the $G_{Y}$ and the $A_{Y}$ IVS-II region; b) the BIVS-II probe; a $1.2 \mathrm{~kb}$ Bam HI/Eco RI fragment of the $B$ IVS-II region; c) the pRK 28 probe; a $0.8 \mathrm{~kb}$ Eco RI/Bgl II fragment that is located $17 \mathrm{~kb}$

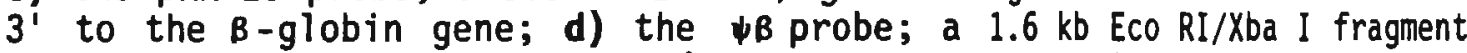
containing the entire $\langle B$ gene; e) the $\varepsilon$ probe; a $1.2 \mathrm{~kb}$ Bam HI/ECO RI fragment containing the entire $\varepsilon$-globin gene; $f$ ) the a probe; a $1.5 \mathrm{~kb}$ Bam HI fragment containing the entire $\alpha-g l o b i n$ gene; $g$ ) the $\zeta$ probe; a $1.9 \mathrm{~kb}$ Hinf I fragment containing the entire $\zeta$-globin gene.

vi. 0ligolabeling of Probes. The random primer oligolabeling procedure (21) is used for radioactive labeling of the probes with chemicals and procedures recommended by the manufacturer (0ligolabeling Kit; Pharmacia LKB). In brief, 50-100 ng of probe is denatured by boiling for 10 minutes in a water-bath and then immediately placed on ice to prevent reannealing. A reaction mixture consisting of a buffered aqueous solution of dATP, dCTP, dGTP, dTTP, and random hexadeoxynucleotides, $50 \mathrm{mCi}$ of $\alpha-32 \mathrm{p}$ dCTP (ICN Biochemicals, Inc., Irvine, CA, USA) and 10 units of klenow fragment are added to a denatured probe in a total volume of $50 \mu 1$, and the reaction is allowed to proceed at $37^{\circ} \mathrm{C}$ for 1 hour. The unincorporated nt is removed from the probe by G-50 Sephadex molecular sieve chromatography with a TE elution buffer (10 mM Tris-HCl, pH 7.5, $1 \mathrm{mM}$ EDTA).

5/c 0ligonucleotide Synthesis. Synthetic oligonucleotides are used as amplification and sequencing primers in the amplification (PCR) and DNA sequencing analysis, and as specific probes in the dot-blot hybridization analysis. The oligonucleotides are synthesized by a solid-phase oligonucleotide synthesis method (22) on an Applied Biosystems 380B DNA synthesizer (Applied BioSystems, Inc., Foster City, CA, USA) in the laboratory in Augusta, GA, USA, and on a Beckman Plus I DNA Synthesizer (Beckman, Palo Alto, CA, USA) in the laboratory in Skopje, Macedonia. Following synthesis, the oligonucleotides are removed from the solid support by an ammonia treatment $\left(55^{\circ} \mathrm{C}\right)$ overnight, dried under vacuum, and purified by G-50 Sephadex molecular sieve chromatography using TE (10 mM Tris-HCl, pH 7.5, 1 mM EDTA) elution buffer. 
5/d PCR. PCR is based upon in vitro amplification of a specific DNA fragment flanked by two synthetic $\overline{0 l} \overline{i g o n u c}$ leotide primers complementary to the opposite strand of the fragment of interest (23). Repeated cycles of heat denaturation, annealing of the primers to the complementary sequences, and extension of the annealed primers with DNA polymerase lead to an exponential accumulation of the target fragment $\left(10^{6}-10^{7}\right.$ copies). The use of programmable themocyclers and heat stable DNA polymerase makes it possible to automate the procedure (24). In this study the PCR method was used for: 1) Generation of large amounts of specific double-stranded DNA fragments to be used in the dot-blot hybridization analysis; 2) generation of large amounts of specific single-stranded DNA fragments used in DNA sequencing analysis; 3) generation of a large amount of a specific fragment of doublestranded DNA spanning the breakpoint of the Croatian deletion; 4) detection of deletional types of a-thal ( $-a^{3.7} ;-a^{4.2} ;--/ a \alpha 20.5 \mathrm{~kb}$ deletion; --/aa MED-I deletion). In this chapter only the basic principles of the procedure will be given. The oligonucleotide primers and probes, as well as specific conditions used for particular applications are described in detail in Chapters 3 and 4 .

In general, the reaction is performed in three phases using the Perkin-Elmer-Cetus Automated Thermalcycler (Perkin-Elmer-Cetus, Norwalk, CT, USA). In the first phase a reaction mixture is prepared containing

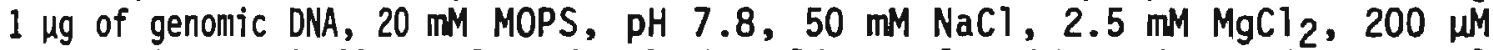
of each dNTP, and $100 \mathrm{pM}$ of each of the oligonucleotide primers in a total volume of $100 \mu \mathrm{T}$. The genomic DNA is initially denatured at $99^{\circ} \mathrm{C}$ for 6 minutes. The temperature is decreased to $85^{\circ} \mathrm{C}$ and 2.5 units of Taq polymerase is added to each sample. Samples are overlaid with 2-3 drops of mineral oil to prevent evaporation. In the second phase the samples are subjected to 30-35 repeated cycles of denaturation at $95^{\circ} \mathrm{C}$ for 1 minute, annealing of the primers at $58-62^{\circ} \mathrm{C}$ for 1.5 minutes, and extension of the arnealed primers at $72^{\circ} \mathrm{C}$ for 2.5-5 minutes. The temperature of annealing and the time of the primer extension depend upon the sequences of the primers used and the length of the region to be amplified, respectively. The third phase concerns the prolonged incubation (up to 10 minutes) at $72^{\circ} \mathrm{C}$ for the complete extension of al1 DNA strands synthesized in the previous steps. Following the reaction, a small aliquot $(5 \mu 1)$ of each sample is run on a $1.5 \%$ agarose gel in the presence of ethidium bromide $(10 \mu \mathrm{g} / \mathrm{ml})$ along with a Hind III-digested $\lambda$-DNA as a size marker; the efficiency of the amplification can be inspected under UV light. The samples are kept at $4^{\circ} \mathrm{C}$ for further analyses.

5/e Dot-Blot Hybridization Analyses. The dot-blot hybridization procedure is used for the detection of single nt substitutions (mutations and polymorphisms) in various regions of the $B-g l o b i n g e n e$ cluster studied. An aliquot $(40 \mu 1)$ of PCR amplified DNA is denatured with $0.04 \mathrm{M} \mathrm{NaOH}$ and blotted in duplicate on a nylon membrane (Zeta Probe Nylon Membrane; BioRad) under vacuum using a spotting device (Bio-Dot; Bio-Rad). The DNA is fixed to the membranes by baking in a vacuum oven at $80^{\circ} \mathrm{C}$ for 2 hours. Two allele-specific oligonucleotide probes, both 19 nts long, are synthesized for each of the mutations studied; one (normal) is complementary to the normal sequence, and the other (mutant) with an identical sequence except for the substitution which is usually positioned in the center of the probe. The normal and the mutant probes are end-labeled at the $5^{\prime}$ 
end to a high activity with $\gamma$-32p-dATP $(W 7000 \mathrm{Ci} / \mathrm{mM}, 160 \mathrm{mCi} / \mathrm{ml} ;$ ICN) by $\mathrm{T}_{4}$ polynucleotide kinase [United States Biochemica] (USB), Cleveland, OH, USA] for $1-2$ hours at $37^{\circ} \mathrm{C}$. The unincorporated $\mathrm{nt}$ is removed from the probes using either G-50 Sephadex molecular sieve chromatography with TE elution buffer or by commercially available Nensorb (NEN) columns (NEN Products, DuPont) under the conditions recommended by the manufacturer. The activity of the probes as CPM is determined in a scintillation counter (Beckman). The duplicate membranes are prehybridized for 30 minutes at $55^{\circ} \mathrm{C}$ in separate, sealed plastic bags, with $10 \mathrm{ml}$ of prehybridization solution containing $5 \times$ SSPE, $5 \times$ Denhardt's, $0.5 \%$ SDS $(20 \times S S P E=3.6 \mathrm{~m} \mathrm{NaCl}$,

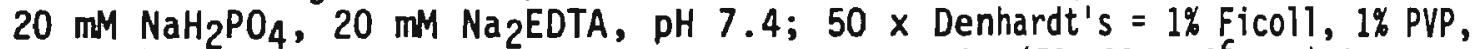
1\% BSA). Following prehybridization, the probe $\left(50-100 \times 10^{6} \mathrm{cpm}\right)$ is added to a particular membrane, and the hybridization is performed in a circulating water-bath for 1-2 hours. The temperature of hybridization varies for each probe, depending upon the $\mathrm{Tm}$ of the probe, which can be calculated from its nt content with a formula $\mathrm{Tm}=4 \times(G+C)+2 \times(A+T)$. Following hybridization, the membrane is washed twice for 10 minutes at room temperature with $2 \times$ SSPE, $0.1 \%$ SDS solution. The mernbranes are washed with TMAC washing solution (3.0 M TMAC, $50 \mathrm{mM}$ Tris-HCl, $\mathrm{pH} 8.0,2.0 \mathrm{mH}$ EDTA, $0.1 \%$ SDS) solution for 20 minutes at $42^{\circ} \mathrm{C}$, followed by a second wash at $58^{\circ} \mathrm{C}$ for 30 minutes. The use of TMAC in a washing solution equilibrates the A-T and G-C bonding strength differences, thus allowing the use of the same temperature for stringent washes for probes of the same size (25). After washing, the membranes are blotted dry, wrapped in plastic film, and autoradiographed by exposure to Kodak $X$-ray film for 2-12 hours at $-70^{\circ} \mathrm{C}$. A representative result showing the identification sequence variations in the $G_{\gamma}$ and $A \gamma 5^{\prime}$ flanking region among $S S$ patients with different haplotypes is presented in Fig. $2 / 3$.

5/f DNA Sequencing. DNA sequencing analysis was most extensively used in this study for the determination of the primary sequence of several regulatory regions in the $\beta$-globin gene cluster (the $\beta-$, G $-A_{\gamma}-g$ lobin gene promoters, the $G_{\gamma}$ - and Ay-IVS-II regions, the HS-2 of the LCR), for the determination of $\beta$-thal mutations in particular families, and for the determination of the exact breakpoint of the Croatian deletion. The analysis was performed on single-stranded, PCR amplified, DNA templates with the dideoxy chain termination method (26) using a Sequenase Version 2.0 DNA Sequencing Kit (USB). DNA sequencing comprises three phases: 1) Synthesis and purification of single-stranded templates, 2) sequencing reaction, and 3) denaturing PAGE.

i. Synthesis and Purification of Single-Stranded DNA Templates. Ampl ification of single-stranded DNA templates is performed using similar methodology as described in section 5/f for the double-stranded PCR amplification except for an unbalanced ratio of the amplification primers of $100 \mathrm{pM}$ to $1 \mathrm{pM}$. The amplified DNA is purified by precipitation with one volume of $2.5 \mathrm{M}$ ammonium-acetate and two volumes of ice-cold ethanol at room temperature for 15 minutes. The mixture is centrifuged in a microcentrifuge at $4^{\circ} \mathrm{C}$ for 15 minutes, and the resulting pellet washed 4-5-times with $70 \%$ ethanol. The pellet is dried under vacuum and dissolved in $10 \mu \mathrm{l}$ of water. One $\mu 1$ of the DNA solution is electrophoresed on a 1.5\% agarose gel along with $0.3 \mu \mathrm{Mg} M-13$ control single-strand DNA for monitoring the recovery and for an estimation of the DNA concentration. 
Mutant

$\bullet \bullet \bullet \bullet \bullet$

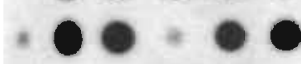

$\bullet \bullet$

I
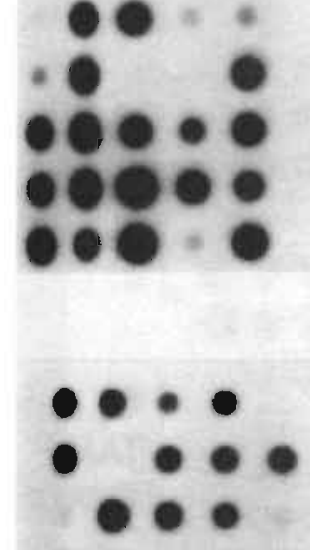

II

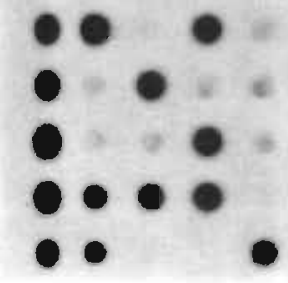

Mutant

(-158T)

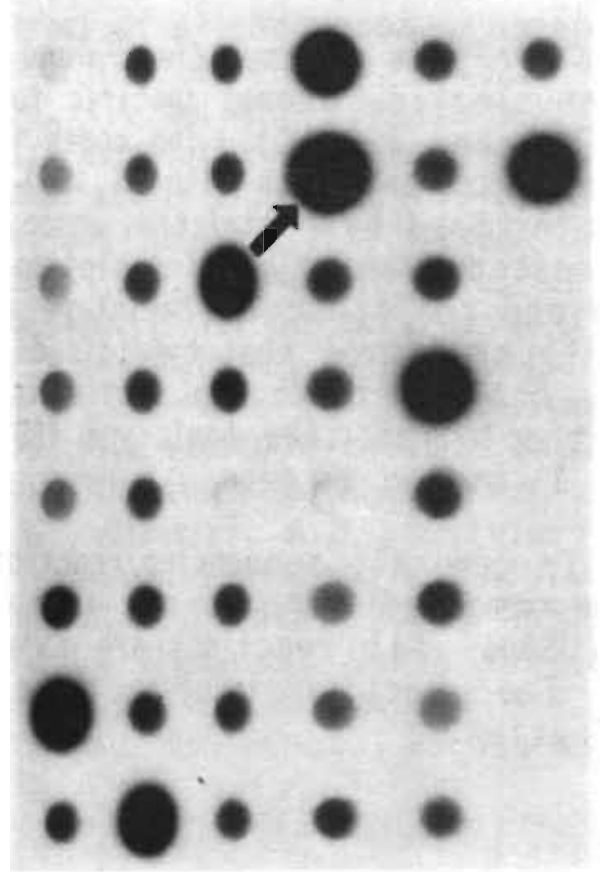

Normal

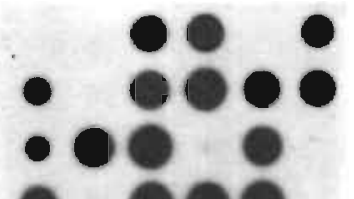

G $\mathrm{G}_{\gamma}-369: \mathrm{C} \rightarrow \mathrm{G}$

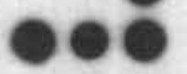

○

$A \gamma-657: G \rightarrow T$
-

-

$\circ \bullet$

\section{Normal \\ $(-158 \mathrm{C})$}

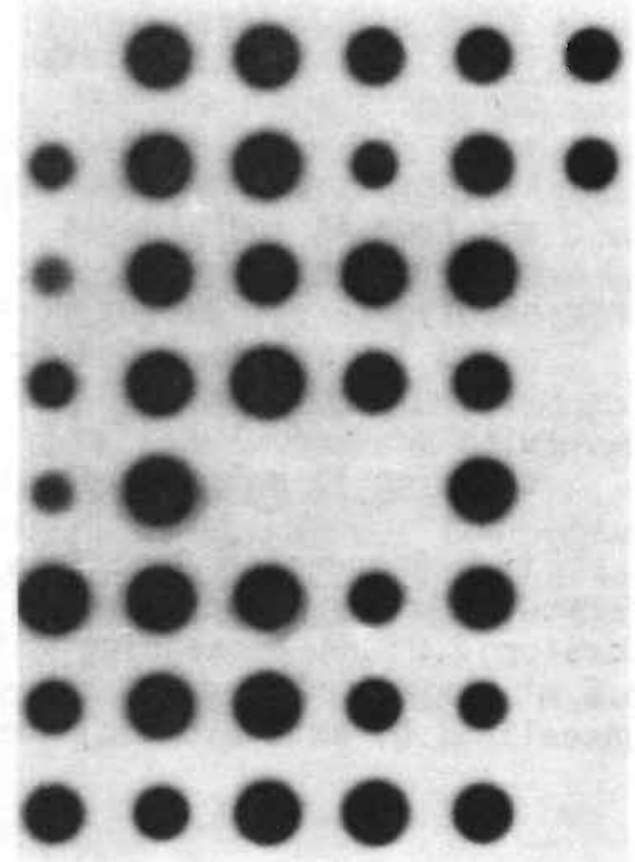




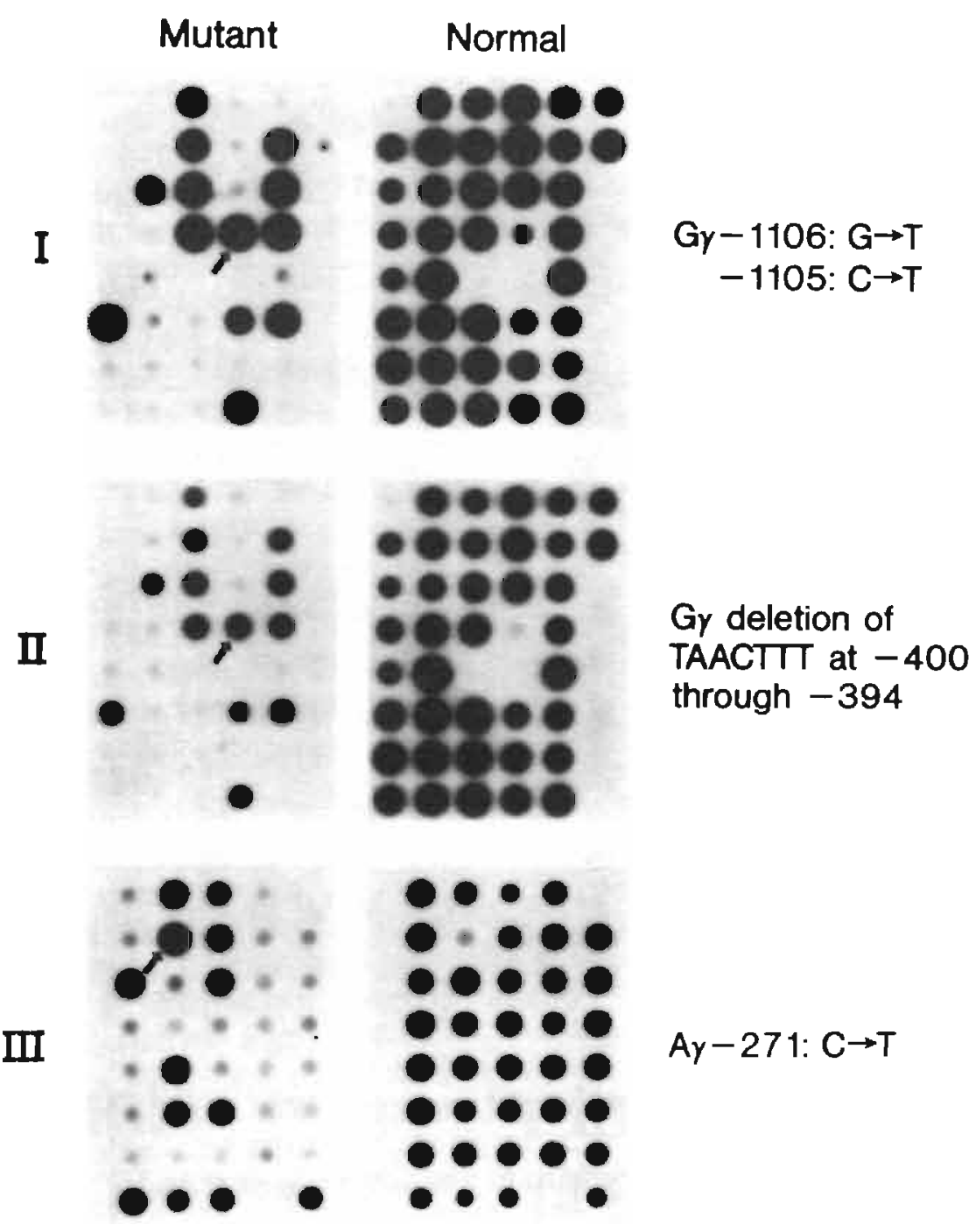

FI6. 2/3. Dot-blot hybridization analysis of amplified $G_{\gamma}$ and $A_{\gamma}$ promoter sequences with several oligonucleotide probes specific for $\beta S$ haplotypes \#19 (A), \#3 and \#31 (B), and \#20 (C). The codes indicate the haplotypes of the DNA samples from patients with SS, $S-\beta$-thal or AS, and from $A A$ individuals as determined by restriction endonuclease mapping analysis $(1,2)$. " 0 " indicates an atypical haplotype. The only homozygote for haplotype \#20 and the other for haplotype \#3 are indicated by arrows. One $\beta$-thal chromosome that hybridized with the Ar -271 (G)्र) mutation (C-III, bottom right; the sample is identified with an arrow) has a $5^{\prime}$ subhaplotype like haplotype \#20 except for the Hinc II polymorphic site $3^{\prime}$ to the $\Psi \beta$ gene.

ii. Sequencing Reactions. In general, sequencing reactions are performed following the protocol recommended for the use of the Sequenase Version 2.0 DNA Sequencing Kit (USB). All reactions are done in sterile $1.5 \mathrm{ml}$ Eppendorf capped tubes. The reaction involves three steps: annealing; b) extension, c) termination. 


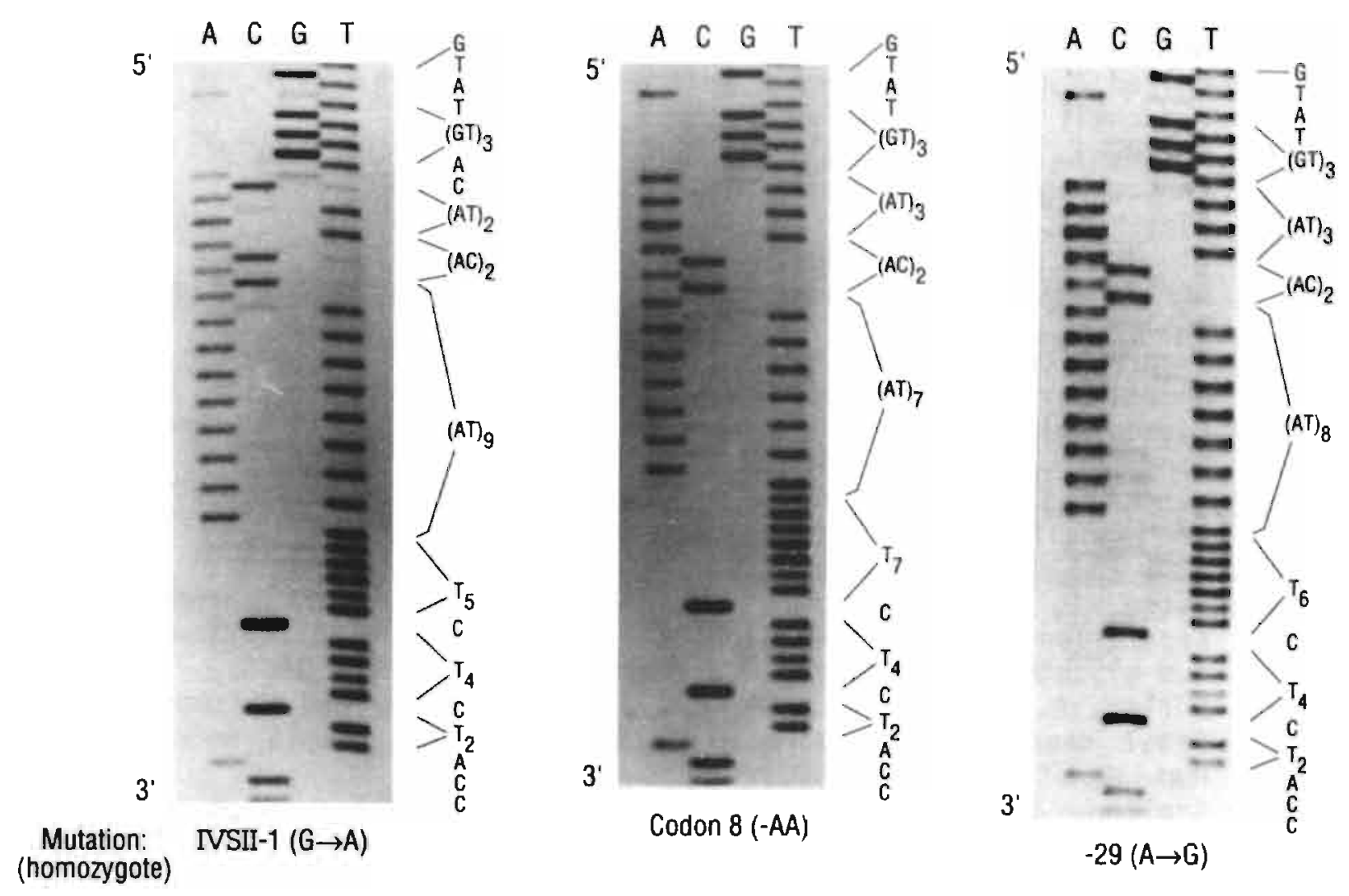

FI6. 2/4. Parts of sequencing gels showing the $(A T) X(T)_{Y}$ motifs in three homozygous $B$-thal patients; IVS-I-1 $(\mathbf{G}>A) ; \operatorname{CD~} 8(-A A) ;-29(A>G)$.

\section{References}

1. Hattori, Y., Kutlar, F., Kutlar, A., McKie, V.C., and Huisman, T.H.J.: Haplotypes of ${ }_{B} S$ chromosomes among patients with sickle cell anemia from Georgia. Hemoglobin, 10:623, 1986.

2. Hattori, Y., Kutlar, F., Mosley, C.J., Mayson, S.M., and Huisman, T.H.J.: Association of the level of $G_{\gamma}$ chain in the fetal hemoglobin of normal adults with specific haplotypes. Hemoglobin, 10:185, 1986.

3. Kutlar, A., Hattori, Y., Bakioglu, I., Kutlar, F., Kamel, K., and Huisman, T.H.J.: Hematological observations on Arabian SS patients with a homozygosity or heterozygosity for a ${ }_{B} S$ chromosome with haplotype \#31. Hemoglobin, 9:545, 1985.

4. Bakioglu, I., Hattori, Y., Kutlar, A., Mathew, C., and Huisman, T.H.J.: Five adults with mild sickle cell anemia share a $\beta^{S}$ chromosome with the same haplotype. Am. J. Hematol., 20:297, 1985.

5. Oner, C., Dimovski, A.J., Olivieri, N.F., Schiliro, G., Codrington, J.F., Fattoum, S., Adekile, A.D., Oner, R., Yuregir, G.T., Altay, 6., Gurgey, A., Gupta, R.B., Jogessar, V.B., Kitundu, M.N., Loukopoulos, D., Tamagnini, G.P., Ribeiro, M.L.S., Kutlar, F., Gu, L-H., Lanclos, K.D., and Huisman, T.H.J.: $B$ S Haplotypes in various world populations. Hum. Genet., 89:99, 1992. 
6. Righetti, P.G., Gianazza, E., Bianchi-Bosisio, A., and Cossu, G.: Conventional isoelectric focusing and immobilized $\mathrm{pH}$ gradients for hemoglobin separation and identification, in The Hemoglobinopathies, edited by T.H.J. Huisman, Methods in Hematology, Vol. 15, page 47, Churchill Livingstone, Edinburgh, 1986.

7. Betke, K., Marti, H.R., and Schlicht, I.: Estimation of small percentages of foetal haemoglobin. Nature, 184:1877, 1959.

8. Singer, K., Chernoff, A.I., and Singer, L.: Studies On Abnormal Hemoglobins. I. Their demonstration in sickle cell anemia and other hematological disorder by means of alkali denaturation. Blood, 6:413, 1951.

9. International Committee for Standardisation in Haematology. Recommendations for foetal haemoglobin reference preparation and foetal haemoglobin determination by the alkali denaturation method. $\mathrm{Br}$. $\mathrm{J}$. Haema tol., 42:133, 1979.

10. Huisman, T.H.J. and Jonxis, J.H.P.: The Hemoglobinopathies Techniques of Identification, Clinical and Biochemical Analysis, Vol. 6, pages 120, 722, Marcel Dekker, Inc., New York, 1977.

11. Bisse, E. and Wieland, H.: High-performance liquid chromatographic separation of human haemoglobins - Simultaneous quantitation of foetal and glycated haemoglobins. J. Chromatogr., 434:95, 1988.

12. Kutlar, A., Kutlar, F., Gu, L-G., Mayson, S.M., and Huisman, T.H.J.: Fetal hemoglobin in normal adults and $\beta$-thalassemia heterozygotes. Hum. Genet., 85:106, 1990.

13. Shelton, J.B., Shelton, J.R., and Schroeder, W.A.: High performance liquid chromatographic separation of globin chains on a large-pore $\mathrm{C}_{4}$ column. J. Liq. Chromatogr., 7:1969, 1984.

14. Kutlar, F., Kutlar, A., and Huisman, T.H.J.: Separation of normal and abnormal hemoglobin chains by reversed-phase high-performance liquid chromatography. J. Chromatogr., 357:147, 1986.

15. Gonzalez-Redondo, J.M., Stoming, T.A., Lanclos, K.D., Gu, Y.C., Kutlar, A., Kutlar, F., Nakatsuji, T., Deng, B., Han, I.S., McKie, V.C., and Huisman, T.H.J.: Clinical and genetic heterogeneity in Black patients with homozygous $B$-thalassemia from the Southeastern United States. Blood, 72:1007, 1988.

16. Alter, B.P., Goff, S.C., Efremov, G.D., Gravely, M.E., and Huisman, T.H.J.: Globin chajn electrophoresis: A new approach to the determination of the $G_{Y} / A_{\gamma}$ ratio in foetal haemoglobin and to studies of globin synthesis. Br. J. Haematol., 44:527, 1980.

17. Schroeder, W.A. and Huisinan, T.H.J.: The Chromatography of Hemoglobin, Clinical and Biochemical Analysis, Vol. 9, Marcel Dekker, Inc., $\overline{\text { New }}$ York, 1980.

18. Poncz, M., Solowiejczyk, D., Harpel, B., Mory, Y., Schwartz, E., and Surrey, S.: Construction of human gene libraries from small amounts of peripheral blood: Analysis of B-like globin genes. Hemoglobin, $6: 27,1982$.

19. Southern, E.M.: Detection of specific sequences among DNA fragments separated by gel electrophoresis. J. Mol. Biol., 98:503, 1975.

20. Blattner, F.R., Blechl, A.E., Dennistron-Thomson, K., Faber, H.E., Richards, J.E., Slightom, J.L., Tucker, P.W., and Smithies, 0.: Cloning of human fetal $\gamma$ globin and mouse $\beta$ type globin DNA: Preparation and screening of shutguns collections. Science, 202:1284, 1978. 
21. Freiberg, A.P. and Vogelstein, B.: A technique for radiolabeling DNA restriction endonuclease fragments to high specific activity. Analyt. Biochem., 132:6, 1983.

22. Matteucci, M.D. and Caruthers, M.H.: Synthesis of deoxyoligonucleotides on a polymer support. Biotechnology, 24:92, 1992.

23. Saiki, R.K., Scharf, S., Faloona, F., Mullis, K.B., Horn, G.T., Erlich, H.A., and Arnheim, N.: Enzymatic amplification of B-globin genomic sequences and restriction site analysis for diagnosis of sickle cell anemia. Science, 230:1350, 1985.

24. Saiki, R.K., Gelfand, D.H., Stoffel, S., Scharf, S.J., Higuchi, R., Horn, G.T., Mullis, K.B., and Erlich, H.A.: Primer directed enzymatic amplification of DNA with a thermostable DNA polymerase. Science, 239:487, 1988.

25. Wood, W.G., Gitschia, J., Lasky, L.A., and Lawn, R.N.: Base composition independent hybridization in tetramethylammonium chloride. A method for oligonucleotide screening of highly complex gene libraries. Proc. Nat1. Acad. Sci. USA, 82:1585, 1985.

26. Sanger, F., Nicklen, S., and Coulson, A.R.: DNA sequencing with chain-terminating inhibitors. Proc. Nat1. Acad. Sci. USA, 74:5463, 1977. 



\section{FETAL HEMOGLOB I N \\ IN SICKLE CELL ANEMIA}

3a Sequence Variations in the $5^{\prime}$ Flanking and IVS-II Regions of the $G_{\gamma}$ - and $A_{\gamma}-61$ lobin Genes of $\beta S$ Chromosomes With Five Different Haplotypes

3b Certain Mutations Observed in the 5' Sequences of the $G_{\gamma-\text { and }} A_{\gamma}$-Globin Genes of ${ }_{B} S$ Chromosomes are Specific for Chromosones With Major Haplotypes

3c ${ }_{\beta} S$ Haplotypes in Various Morld Populations

3d Sequence Variations in the 5' Hypersensitive Site-2 of the Locus Control Region of $B S$ Chromosomes are Associated With Different Levels of Fetal Globin in Hemoglobin S Homozygotes

3e Haplotype-Specific Sequence Variations in the Locus Control Region (5' Hypersensitive Sites 2, 3, 4) of is Chromosomes 

CHAPTER 3a

SEQUENCE VARIATIONS IN THE $5^{\prime}$ FLANKING AND IVS-II REgIONS OF THE $\mathbf{G}_{\gamma-\text { AND }}$ $A_{\gamma-G L O B I N}$ GENES OF $\beta$ S CHROMOSOMES WITH FIVE DIFFERENT HAPLOTYPES

\author{
K.D. Lanclos, C. Oner, A.J. Dimovski, and T.H.J. Huisman \\ Department of Cell and Molecular Biology \\ Medical College of Georgia, Augusta, GA 30912-2100, USA
}

(Adapted from: Blood, $77: 2488-2496,1991$ )

\begin{abstract}
We have amplified and sequenced the $5^{\prime}$ flanking and the IVS-II regions of both the $G_{\gamma}$ and $A_{\gamma-g l o b i n}$ genes of the ${ }_{\beta} S$ chromosomes from SS patients with homozygosities for five different haplotypes. The sequencing data, compared with previously published sequences for the normal chromosomes $A$ and $B$, show many similarities to chromosome $B$ for haplotypes \#19, \#20, and \#17, while haplotypes \#3 and \#31 are remarkably similar to chromosome $A$ and also similar to each other. Several unique mutations were found in the $5^{\prime}$ flanking regions $\left(G_{Y}\right.$ and $\left.A_{Y}\right)$ of haplotypes \#19 and \#20 and in the IVS-II segments of the same genes of haplotypes \#19, \#20, and \#17; the IVS-II of haplotypes \#3 and \#31 were identical to those of chromosome A. Dot-blot analyses of amplified DNA from additional SS patients with specific probes have confirmed that these mutations are unique for each haplotype. The two general patterns that have been observed among the five haplotypes have most probably arisen by gene conversion events between the $A$ and $B$ type chromosomes in the African population. These patterns correlate with high and low fetal $\mathrm{Hb}$ expression, and it is speculated that these and other yet unknown gene conversions may contribute to the variations in $H b F$ and $G_{Y}$ levels observed among $S S$ patients. In vitro expression experiments involving the $21.3 \mathrm{~kb} 5^{\prime}$ flanking regions of the ${ }^{-}$and A $\mathrm{yglobin}$ genes of the ${ }_{B} S$ chromosomes with the five different haplotypes failed to detect differences between the levels of expression, suggesting that the sequence variations observed between these segments of DNA are not the primary cause of the differences in $\mathrm{Hb} F$ levels among the $S S$ patients.
\end{abstract}




\section{INTRODUCTION}

The ${ }_{B} S$ mutation, i.e. $A \rightarrow T$ at $C D 6$ leading to the Glu+Val substitution in the $\boldsymbol{B}$ chain, is known to occur on different genetic backgrounds defined by their haplotypes (1-7). These haplotypes have been named Benin, Bantu [CAR (Central African Republic)], Senegal, Saudi Arabian-Indian, and Cameroon ( $\mathrm{Ca}$ or $\mathrm{A}_{\gamma}{ }^{\top}$ ) types, and were identified as haplotypes \#19, $\# 20$, \#3, \#31 (8), and \#17 (9), respectively. Haplotypes $\# 19$ and \#20 are the major types present in SS patients living in the southeastern part of the United States (9); their hematologic data and their relatively low $H b F$ levels indicate a rather severe disease with severe anemia. Haplotypes \#3 and \#17 are less frequently observed in the same population, while haplotype \#31 has been found only in a few families visiting the United States from Saudi Arabia or..India $(10,11)$. SS patients with haplotypes \#3 and \#31, and particularly the latter, are characterized by milder disease with higher $H b F$ levels. Moreover, the relative amounts of the $G_{\gamma}$ and $A_{\gamma}$ chains in the $\mathrm{Hb} F$ of these patients (about $70 \% \mathrm{G}_{\gamma}$ and $30 \% \mathrm{~A}_{\gamma}$ ) are considerably different from those observed in SS patients with haplotypes \#19, $\# 20$, and $\# 17$ (about $40 \% G_{\gamma}$ and $60 \% A_{\gamma}$ ) (9); presumably the $C+T$ mutation at position -158 in the $G_{\gamma}$ promoter is (at least in part) responsible for this difference.

Because of the great variability in clinical expression and the consistent differences in $H \mathrm{H} F$ ievels of SS patients with different haplotypes, we have initiated sequence analyses of the two $r$-globin genes and their flanking regions to detect significant differences that may be important for the understanding of the variations in $Y$ chain synthesis. The $5^{\prime}$ flanking regions were chosen because of their potential regulatory role in gene expression. These regions are known to contain both positive (enhancer) and negative (silencer) regulatory elements upstream from the consensus promoter sequences (12-15). We also investigated the IVS-II region because major introns may have sequences that have either enhancer activity $(16,17)$ or are involved in the regulation of mRNA splicing through the coupling of polyadenylation and mRNA transport $(18,19)$. Most recent data have suggested that the IVS-II region is required for the regulation of expression by the human B-globin dominant control region (DCR) (20). Here we report sequence data for these regions of both the $G_{\gamma}$ - and $A_{\gamma-g l 0-}$ bin genes of five patients with a homozygosity for either one of the five different haplotypes. Results from in vitro expression experiments are also included.

\section{MATERIALS AND METHODS}

Patients. Blood samples were collected from several SS patients studied previously (9-11). Five patients were selected because of a homozygosity for a specific haplotype; their hematologic data at the time of collection are summarized in Table $3 a / 1$. Additional blood samples were from SS patients with haplotypes 19/19, 19/20, 19/3, 20/20, 3/20, 3/3, $17 / 17,19 / 17,20 / 17$, and $31 / 31$. These subjects have also been studied in detail before $(9-11)$. DNA was isolated from the white blood cells by the method of Poncz et al (21). 
TABLE 3a/1. Hematologic and Hb Composition Data

\begin{tabular}{|c|c|c|c|c|c|}
\hline Subject & $\begin{array}{l}\text { A.D. } \\
\text { F-17 }\end{array}$ & $\begin{array}{l}\text { K.R. } \\
F-18\end{array}$ & $\begin{array}{l}\text { L.F. } \\
F-47\end{array}$ & $\begin{array}{l}\text { N.Y.A. } \\
\text { F-31 }\end{array}$ & $\begin{array}{l}\text { N.F. } \\
\text { F-14 }\end{array}$ \\
\hline Haplotype & $19 / 19$ & $20 / 20$ & $3 / 3$ & $31 / 31$ & $17 / 17$ \\
\hline $\mathrm{Hb}(\mathrm{g} / \mathrm{dL})$ & 8.7 & 9.4 & 9.2 & 9.3 & 7.1 \\
\hline $\operatorname{PCV}(L / L)$ & 0.235 & 0.39 & 0.295 & 0.32 & 0.215 \\
\hline $\operatorname{RBC}\left(10^{12} / L\right)$ & 2.55 & 3.31 & 3.54 & 2.98 & 3.05 \\
\hline $\operatorname{MCV}(f L)$ & 92.0 & 88.0 & 83.0 & 107.0 & 70.0 \\
\hline$M C H(p g)$ & 34.1 & 28.4 & 26.0 & 31.2 & 23.3 \\
\hline $\operatorname{MCHC}(g / d L)$ & 37.0 & 32.4 & 31.2 & 29.1 & 33.0 \\
\hline $\mathrm{Hb} \mathrm{A}(q) \mathrm{C}$ & 3.8 & 2.6 & 3.6 & 1.3 & 3.2 \\
\hline$H b F(\%) c$ & 1.8 & 16.6 & 16.5 & 25.5 & 4.0 \\
\hline$G(q) C$ & 38.7 & 41.6 & 74.1 & 70.5 & 43.0 \\
\hline No. of genes & $\alpha a / \alpha \alpha$ & $\alpha \alpha / \alpha \alpha$ & $\alpha \alpha / \alpha \alpha$ & $\alpha a / a \alpha$ & $-\alpha / a \alpha$ \\
\hline
\end{tabular}

a Data 3 weeks after a blood transfusion; Hb A was $10.3 \%$.

b This patient had consistently high Hb F levels (between 15 and 18\%) during the past several years.

C Data by cation exchange HPLC; ${ }^{*} G_{\boldsymbol{\gamma}}$ by reversed phase HPLC.

Asymetric Amplification and Sequencing. The $5^{\prime}$ flanking regions of the ${ }^{G} \gamma-$ and $A_{\gamma}$-globin genes were amplified independently with specific $G_{\gamma}$ and $A_{\gamma} 5^{\prime}$ oligonucleotide primers (23-24 mers) beginning at positions -1227 and -1279 from the Cap site, respectively. The $3^{4}$ amplification primers were located at position +53 and were identical for both genes. Similarly, the IVS-II regions were amplified using specific $3^{\prime}$ reverse primers (19-21 mers located at positions +1242 and +1220 from the Cap sites at the $G_{y}$ and ${ }_{\gamma}$ genes, respectively. The $5^{\prime}$ primer for both genes is located at +479 from the Cap site. For haplotype \#19 an additional reverse primer at position +2744 was used. The sequences of the primers are listed in Table 3a/2. For asymmetric amplification, the reaction mixture contained $1 \mu \mathrm{g}$ of genomic DNA, $20 \mathrm{mmol} / \mathrm{L}$ MOPS, pH 7.8, $250 \mu \mathrm{mol} / \mathrm{L}$ each of dNTPs, $50 \mathrm{mmol} / \mathrm{L} \mathrm{NaCl}, 3 \mathrm{mmol} / \mathrm{L} \mathrm{MgCl} 2,100 \mathrm{pmol}$ of non-limiting primer, $2 \mathrm{pmol}$ of limiting primer, and $2.5 \mathrm{U}$ of Taq polymerase. The PCR was conducted in a Perkin-Elmer-Cetus Thermocycler (Norwalk, CT, USA). The conditions of denaturation, annealing, and extension were $94^{\circ} \mathrm{C}$ for 1 minute, $55^{\circ} \mathrm{C}$ for 1.5 minutes, and $72^{\circ} \mathrm{C}$ for 3 minutes, respectively. The $5^{\prime}$ flanking and IVS-II regions were sequenced directly from the asymmetrically amplified DNA using the dideoxy termination procedure of Sanger et al (22).

Dot-Blot Hybridization. Aliquots of amplified DNA were blotted to nylon membranes and hybridized to specific $5^{\prime}$ end-labeled probes as described before $(23,24)$. The sequences of the probes and their specific locations within the sequences of the 5 ' flanking regions and of the IVS-II regions of the two $\gamma$-globin genes are listed in Table $3 a / 2$. 
TABLE 3a/2. Amplification Primers and Probes for Specific Mutations

Position $\quad 5^{\prime}<$ Sequence $\quad$ Specificity Function

A. Primers

-1227 to -1204

-1279 to -1257

+53 to +30

+479 to +497

+1242 to +1223

+1220 to +1201

+2744 to +2724
ACGTCATAATCTACCAAGGTCATG AGCTTAGGGGATAAACTAATTTG GGCGTCTGGACTAGGAGCTTATTG

GAGAACTTCAAGGTGAGTC

AGGTAGTTGTTCTTCTTGCA

AGGTAGTTGTTCCCCTTCAA TCTGTAGTTCACTCAAAACCC
$G_{\gamma}$ (5' flanking) Direct primer Ar (5' flanking) Direct primer $G_{\gamma}$ and $A_{\gamma}$ (5' flanking) $G_{\gamma}$ and $A_{\gamma} \quad$ Direct primer (IVS-II)

Gr (IVS-II) Reverse primer Ar (IVS-II) Reverse primer Ar (IVS-II) Reverse primer (for haplotype \#19)

Position
Sequence ${ }^{\mathbf{a}}$
$5^{\prime}\left\langle-------->>3^{\prime}\right.$
Specificity

Function

B. Probes

-378 to -380

-1114 to -1096

-407 to -382

\section{CTGGAGCTAGAGACAAGAA \\ TACTTCCTITCATGTTAAG}

$G_{\gamma}\left(5^{\prime}\right.$ flanking) $-369(C+6)$

$G_{\gamma}$ (5' flanking) -1106 (G+T); $-1105(C+T)$

CATGCTITAAACTACAGGC

$G_{y}$ ( $5^{\prime}$ flanking) 6 bp deletion

(3 Ts; 2 As; $1 \mathrm{C}$ )

-672 to -654

TGAGGTAAGCATTAGTTCT

-280 to -262

AGAGAAAAATTGGAATGAC

+540 to +558

TTAGACAACGGAGTATTGA

+686 to +704

+1201 to +1220
$A_{Y}$ (5' flanking) $-657(6+T)$

$A_{Y}\left(5^{\prime}\right.$ flanking) $-271 C_{+} T$ )

$A_{Y}$ (IVS-II)

$A_{Y}$ (IVS-II)

$+549(T+G)$

$+695(\mathrm{C}-\mathrm{T})$

+1202; +1203; +1207;

+1208 (TGGG + GCAA)

a Parts of the sequences that are underlined indicate the positions of the specific mutations.

Transient Expression. The $1.3 \mathrm{~kb} 5^{\prime}$ flanking regions of the $G_{\gamma}$ and $A_{Y}$ genes from five different ${ }_{B} S$ chromosomes each with one of the five different haplotypes were amplified using specific primers as shown in Table $3 a / 2$, but with the addition of Hind III sequences on the $5^{\prime}$ ends. Amplified DNA was purified, digested with Hind III, cloned into the expression vector pSVOCAT, and transfected into $K 562$ cells for CAT expression as previously described $(25,26)$. Each inserted fragment was sequenced to ascertain that the insert was identical to the sequence in genomic DNA, free of Taq errors that occur during amplification, and in the correct orientation. 


\section{RESULTS}

Presentation of the sequence data is limited to a listing of differences observed between the $B S$ chromosomes and the chromosomes $A$ and $B$; data for the latter two chromosomes are from Refs. 27 through 32, and a personal communication (J.L. Slightom, July 1990). Fig. 3a/1 lists the differences from the $5^{\prime} G_{Y}$ and $A_{Y}$ flanking sequences, and Fig. $3 a / 2$ lists those for the IVS-II of the $G_{\gamma}$ and $A_{Y}$ genes.

The Sequence of the $5^{\prime}$ Flanking Regions of the $\mathbf{G}_{\boldsymbol{Y}}$ and $\mathbf{A}_{\boldsymbol{Y}}$-Globin Genes. The data from the two chromosomes $A$ and $B$ indicate six differences in the sequences of the $5^{\prime}$ flanking regions of the $G_{\gamma}$ gene. The sequences for the five $B^{S}$ haplotypes resembled that of chromosome $A$ except for $A G$ at position -535 and -534 , which are like chromosome $B$. The following unique mutations were observed for haplotype \#19: C $\rightarrow$ G at -369 and $\mathbf{A} \rightarrow \mathbf{G}$ at -309; for haplotype \#20: $6+T$ at -1106 and $C \rightarrow T$ at -1105 , and a 6 bp deletion (three Ts, two As, and one C) between -403 to -390 ; for haplotypes \#3 and \#31: $C+F$ at -158 ; for haplotype \#17: none.

of the 13 differences between chromosomes $A$ and $B$ in the $5^{\prime}$ flanking region of the $A_{Y}$ gene, eight are found in haplotype \#19, seven in haplotype $\# 20$, seven in haplotype \#17, six in haplotype \#31, and four in haplotype \#3. Eight of the 13 characteristics found for chromosome B, namely $A$ at -1121 , $T$ at -1101 , $T$ deleted at -611 , A6 at -604 and $-603,6$ at $-588,6$ at -369 , and 6 at +25 , were found in various combinations for the five haplotypes. All types except \#17 have a deleted $T$ at position -611 . All had $A G$ at -604 and -603 , and a $\mathbf{G}$ at position -369. The unique mutations for haplotype \#19 were: $\mathbf{6}+\mathbf{T}$ at -657 ; haplotype \#20: C $-\mathbf{T}$ at -271 ; haplotypes \#3 and \#31: none.

The Sequence of the IVS-II Regions of the ${ }^{G_{Y}}$ and $A_{Y}$-Globin Genes. The sequences of the $G_{Y}$ IVS-II segments of chromosomes $A$ and $B$ differ in four positions and in the repetitive sequence of the $G_{r}$ gene (for position numbers see legend of Fig. $3 a / 2$ ). The five ${ }_{B} S$ chromosomes resembled chromosome $A$ except for differences at position +834 and at the repetitive sequence. Haplotypes $\# 3$ and \#31 have sequences identical to that of chromosome $A$; this is also the case for haplotypes $\# 20$ and \#17, except for the $6 \rightarrow A$ mutation at +834 . Haplotype $\# 19$ also has a unique repetitive sequence.

Numerous differences in the sequences of the IVS-II of the $A_{Y}$ genes of chromosomes $A$ and $B$ have been observed; these are 1isted in Fig. $3 a / 2$ (bottom) and in the legend. The sequences for the ${ }_{B} S$ chromosomes with haplotypes \#3 and \#31 were the same as that for chromosome $A$; this was also the case for haplotype \#20, except for a modified and extended repetitive sequence. Haplotypes \#19 and \#17 had characteristics of both chromosomes $A$ and $B$. Of the 20 differences (excluding the repetitive region) that are characteristic for chromosome B, haplotype \#19 had 13, and haplotype \#17 had 15. In addition, haplotype \#19 had a $T+6$ mutation at +743 , an $A+G$ mutation at +782 , a T66G+6CAA gene conversion $\left(G_{\gamma}\right)$ at positions $+1202,+1203,+1207,+1208$, and a specific repetitive sequence. Haplotype \#17 had a $T+6$ mutation at +549 and a specific repetitive sequence. 

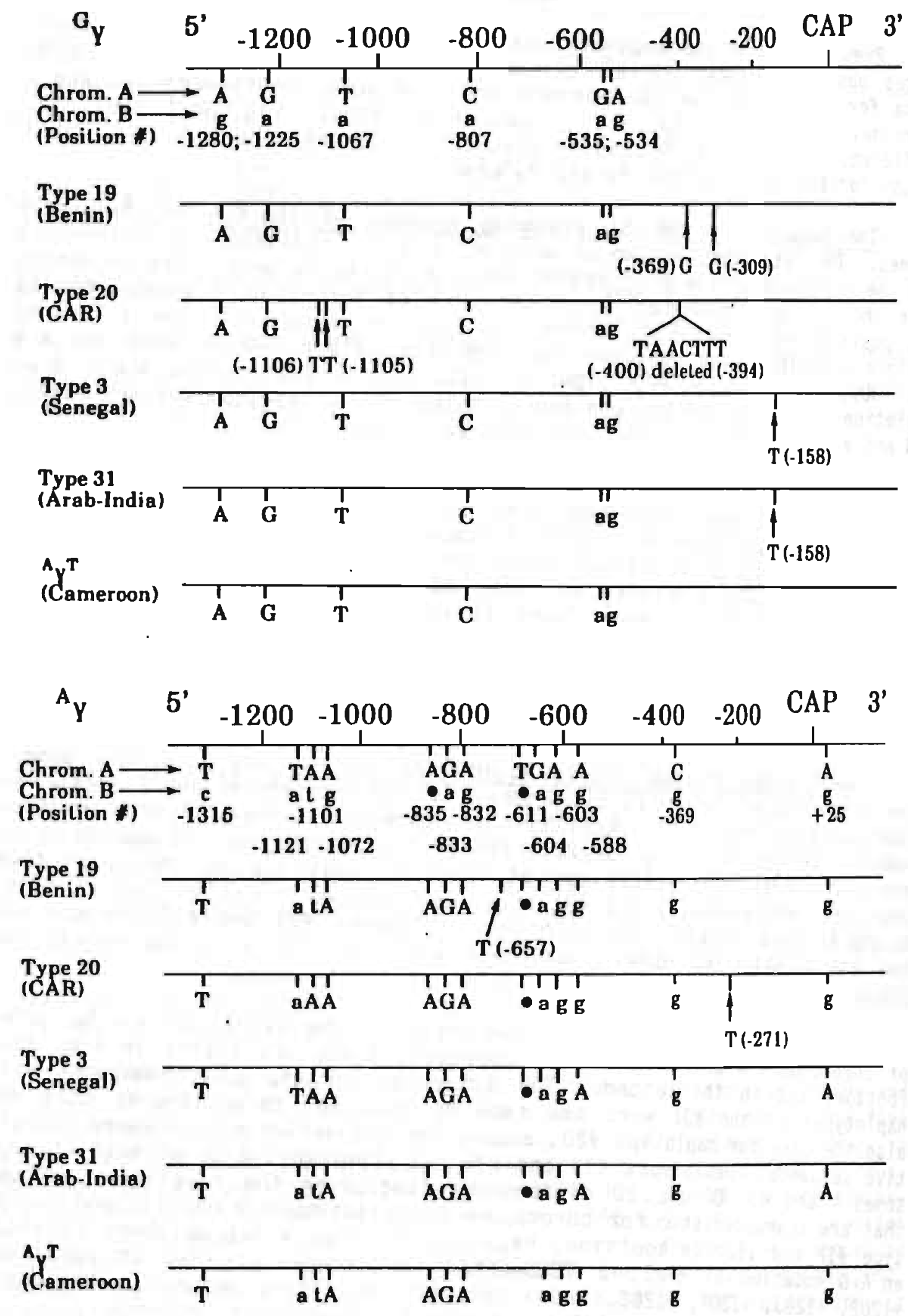

FIG. 3a/1: Legend overleaf. 


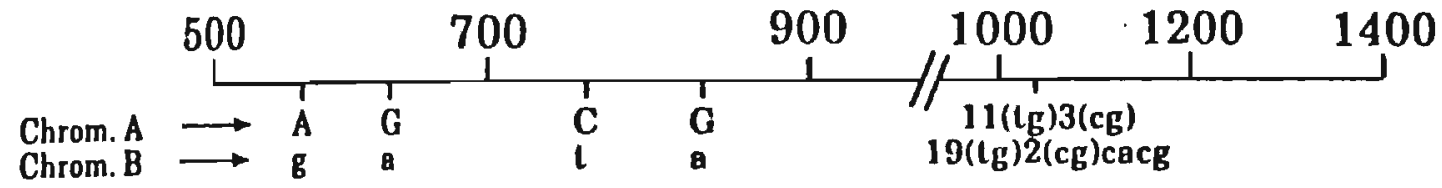

Type 19

(Benin)

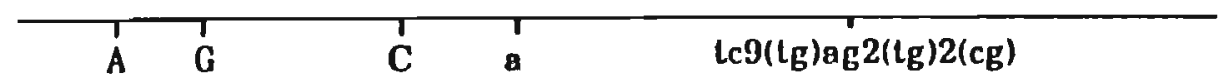

Type 20

(CAR)

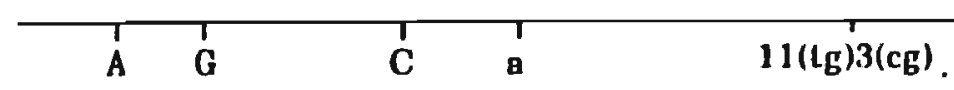

Type 3

(Senegal)

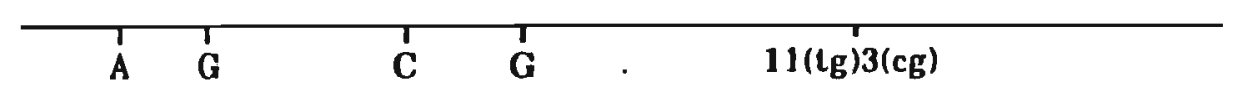

Type 31

(Arab-India)

\begin{tabular}{lllll}
\hline & $G$ & $C$ & $G$ & $11(\lg ) 3(\mathrm{cg})$
\end{tabular}

$\hat{A}_{\text {(Cameroon) }}^{\mathrm{T}}$

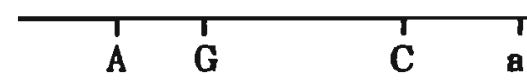

$11(\lg ) 3(\mathrm{cg})$

\section{${ }^{A_{Y}}$ IVS-II}

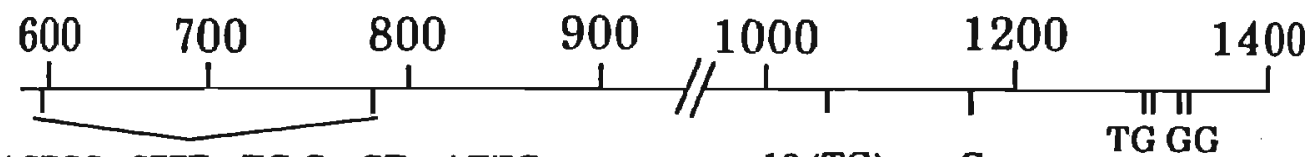

Chrom.A $\longrightarrow$ AACTGC CTTT TG C CT ATTC

Chrom. B $\longrightarrow$ c glcat $\bullet \bullet \bullet$ cal lc $\bullet \bullet \bullet$

13 (TG) G

$9(\mathrm{lg}) 5(\mathrm{cg}) 7(\mathrm{lg}) \mathrm{c}$

Type 19

(Benin)

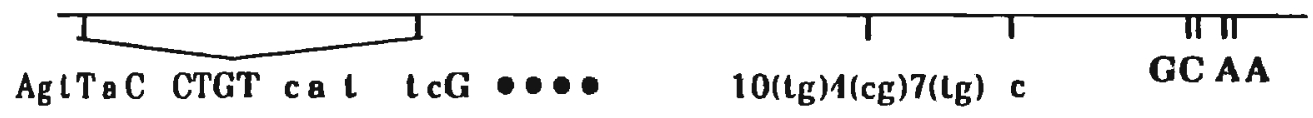

Type 20

(CAR)

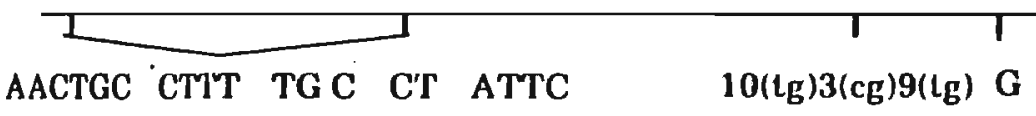

Type 3

(Senegal)

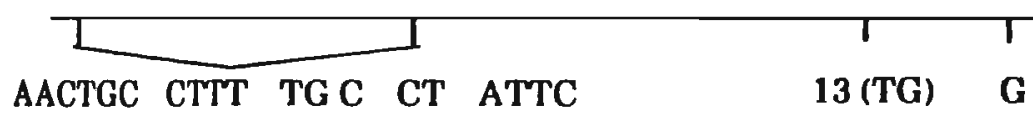

Type 31

(Ârab-India)

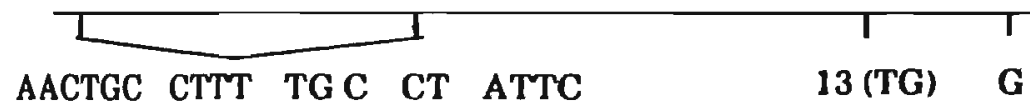

$\hat{A}^{\top}$
(Cameroon)

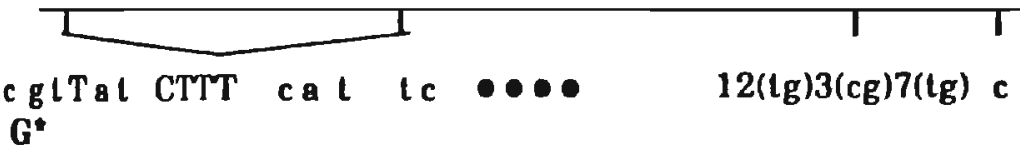

FI6. 3a/2: Legend on the next page. 
FI6. 3a/1. Variations in sequences of the $G_{Y}$ (top) and $A_{Y}$ (bottom) promoter sequences for five SS patients with a homozygosity for the five listed $\$$ haplotypes. Comparison is made to sequences published by Slightom et al (27) for the A chromosome; the data for the B chromosome were also obtained from J.L. Slightom (personal communication, July 1990). Capital letters are used for chromosome $A$ and lower case letters for chromosome B; closed dots (0) indicate that this $n$ t is deleted. Heterozygosity for any of the variations was not observed.

FIG. 3a/2. Summary of the differences in the sequences of the IVS-II ( $G_{Y}$ and $A_{Y}$ ) of the chromosomes from the five SS patients with homozygosities for the five different haplotypes. Presentation of the data is similar to that in Fig. 3a/1. Top: IVS-II of $G_{\gamma}$; four single nt differences (at positions $+605 ;+\overline{669},+774,+834$ ) and a difference between the repetitive sequences at position +1062 have been observed between the two $G_{\gamma}$ IVS-II segments. The five ${ }_{B} S$ haplotypes resemble chromosome $A$ except for position +834 and for the repetitive sequence. Bottom: IVS-II of $A_{Y}$; numerous single nt differences have been found between chromosomes $A$ and $B$ [at positions $+514,+605,+648,+670$, $+677,+695,+741$ to +744 ( 4 nt deletion), $+753,+755,+722,+780$, $+781,+791$ to +794 ( $4 \mathrm{nt}$ deletion), +1159$]$, and in the repetitive sequences starting at +1062 . Haplotypes $\# 3$ and $\# 31$ have sequences identical to that of chromosome $A$. The sequence of the $S$ chromosome with haplotype \#19 is unique $(T+G$ at $+743, A+6$ at +782 , and T666 GCAA at $+1202,+1203,+1207,+1208)$; the ${ }_{B} S$ chromosome with haplotype \#17 is also different at several positions $(T+6$ at +549$)$.

0ligonucleotide Hybridization. To determine if specific mutations were characteristic for the individual haplotype, DNA samples from additional Black patients were amplified and analyzed by dot-blot hybridization with specific probes. The results indicate that the $C+6$ mutation at -369 $\left({ }^{G}\right)$ and the $G \rightarrow T$ mutation at $-657\left(A_{Y}\right)$ were specific for haplotype \#19; that the $C+T$ at -1105 and $\mathbf{G} \rightarrow T$ at $-1106\left(G_{Y}\right)$, the 6 bp deletion between positions -403 to $-390\left(G_{Y}\right)$, and the $C_{-}$T mutation at $-271\left(A_{\gamma}\right)$ were specific for haplotype \#20, and that the $C+T$ mutation at -158 was specific for haplotypes \#3 and \#31.

The AYIVS-II region from the same group of patients was amplified and hybridized with three specific probes. The T666+6CAA conversion is specific for DNA of haplotype \#19. The $C \rightarrow T$ mutation at +695 appears to be specific for haplotype \#17, although two chromosomes with haplotype \#19 have this mutation, whereas the $T+6$ mutation at +549 occurred on chromosomes with both haplotypes \#19 and \#17.

In Vitro Expression. The data from duplicate analyses in two separate transfections are shown in Table 3a/3. No differences were observed between the levels of CAT expression for any of the $5^{\prime}$ flanking regions of the five haplotypes. 
TABLE 3a/3. Effect of the 5' Flanking Regions of the $G_{Y}$ - and AY-Globin Genes on the Expression of CAT in K 562 Cells

\begin{tabular}{lccccc}
\hline & \multicolumn{5}{c}{ Haplotype } \\
\cline { 2 - 6 } Construct & $\# 19$ & $\# 20$ & $\# 17$ & $\# 3$ & $\# 31$ \\
\hline 5' Flanking $G_{Y}$ & 5,262 & n.d. & 5,880 & 6,693 & 4,695 \\
5' Flanking $A_{Y}$ & 4,168 & 6,627 & n.d. & 5,232 & 4,856 \\
\hline
\end{tabular}

Values $(\mathrm{cpm})$ are normalized between experiments to the control PRSVCAT level $(168,815 \mathrm{cpm})$.

\section{DISCUSSION}

Perhaps the most important observation made in the present study is the close similarity of the sequences of the $B S$ haplotypes \#3 and \#31 which, moreover, are quite similar to that of chromosome $A$. Data given in Fig. $3 a / 2$ show that the $G_{\gamma}$ and A $\gamma$ IVS-II segments are the same for haplotypes \#3 and \#31 and are also identical to that of chromosome $A$. The $G_{\gamma}$ $5^{\prime}$ flanking sequences of haplotypes \#3 and \#31 are the same but differ only in two positions from that of chromosome $A$. The sequences of the $A_{\gamma}$ $5^{\prime}$ flanking regions differ in two positions $(-1121$ and -1101$)$ and differ from that of chromosome $A$ in four other positions $(-611,-604,-603$, and -369; Fig. 3a/1). The only correlation between altered expression (i.e. increased $G_{Y}$ chain synthesis) and change in sequence is the $C+T$ mutation at position -158 to $G_{Y}(33)$.

In contrast, chromosomes associated with low levels of Hb F, i.e. BS chromosomes with haplotypes \#19, \#20, and \#17, show multiple differences in the $G_{Y}$ and $A_{\gamma} 5^{\prime}$ flanking regions and in the IVS-II. Perhaps the more significant changes are the mutations in the $A_{\gamma} 5^{\prime}$ flanking regions where a $G$ is present at positions -588 and +25 , whereas chromosomes associated with high levels of $H b F$ expression have an $A$ at these positions. The region between positions -611 and -588 in the $A_{\gamma}$ promoter appears to be a "hot spot" for recombination and gene conversion events between chromosomes $A$ and $B(28,34)$. The major sequence differences in the $G_{\gamma} 5^{\prime}$ flanking region are in the $B S$ chromosomes with haplotype \#19 ( 6 at -369 and -309 ) and $\# 20$ ( $T$ at -1106 and -1105 , and a 6 bp deletion between -403 to $-390)$; these changes are specific for haplotype $\# 20$. Al though patient K.R. with haplotype \#20 who donated blood for the sequencing analyses had a high $\mathrm{Hb} F$ value of 16 to $17 \%$ (Table $3 a / 1$ ), we have tested $70 \mathrm{BS}^{\mathrm{S}}$ chromosomes with haplotype \#20 from other SS patients with much lower Hb $F$ values, and all of them have the same changes including the 6 bp deletion between positions -403 to $-3905^{\prime}$ to $G_{\gamma}$. The 6 bp deletion was not found in the DNA of SS patients with any of the other four haplotypes or in the DNA of 124 normal persons. It is interesting to note that all $70 \mathrm{~B} S$ chromosomes with haplotype \#20 carried the 6 bp deletion in conjunction with the $C+T$ mutation at position -271 ; this is one of the three Bantu variations reported by Bouhassira and Nagel (35). 
A B-type conversion to $A$ is present in the IVS-II of the $G_{\text {rglobin }}$ gene at position +834 for haplotypes $\# 19, \# 20$, and $\# 17$. The repetitive sequence at +1062 for haplotypes $\# 20, \# 17, \# 3$, and \#31 is the same as that of chromosome A, but varies considerably for haplotype \#19. The IVS-II segments of the $A_{\gamma-g l o b i n}$ gene for haplotypes \#19, \#20, and \#17 contain, like those of the $A_{\gamma} 5^{\prime}$ flanking regions, many more $B$-type conversions. Furthermore, the region where major differences were found is the hypervariable region (HVR) located around position +1062 ; chromosomes with these three haplotypes have variable sequences which, to some extent, resemble those found in chromosome B. Haplotype \#19 is the most unusual among the three chromosome types. Its structure is B-like, particularly in the HVRs of the $G_{Y}$ and $A_{Y}$ IVS-II segments, but it has many other substitutions; some of these have been reported by Stoeckert et al (28). Another characteristic change is the TG to $\mathbf{G C}$ and the $\mathbf{6 6}$ to $\mathbf{A A}$ conversion at positions $+1202,+1203$, +1207 , and +1208 , respectively; the GCAA sequence is that observed for the GIVS-II at these positions. Data by dot-blot analysis of amplified DNA from ${ }_{B} S$ chromosomes of a limited number of SS patients with different haplotypes, using probes specific for a few of these mutations have indicated that changes are characteristic for a specific haplotype, although some mutations appear to be polymorphisms.

Although the sequence data for the five ${ }_{\beta} S$ chromosomes fall into two patterns that correlate with high and low fetal Hb expression, no evidence has been obtained to implicate specific changes in the $5^{\prime}$ flanking region as being directly involved in determining the $G_{Y}$ to $A_{\gamma}$ ratios (the known exception is the $C+T$ mutation at -158 of $G_{Y}$ ) or the relative levels of $\mathrm{Hb} F$. However, one cannot rule out a role for these sequences in regulating expression because it is not possible to duplicate the phenotypic conditions that are present during the anemic stress of SS disease in the adult in a cell culture. Indeed, several mutations responsible for nondeletional HPFH were also not over-expressed in the $K 562$ fetal environment (36). Because elevated fetal $\mathrm{Hb}$ in SS, unlike the HPFH condition, is associated with a homozygosity for the $B S$ gene and an accompanying anemic stress, the overall expression of the $\gamma$ genes will most likely prove to be a complex interaction between certain transacting factors and specific primary sequences (i.e. locus activating regions, 5' flanking regions, and enhancers) within specific developmental stages of erythroid cells.

Acknowledgements. This study was supported by USPHS Research Grant HLB-45144; this is contribution \#1258 from the Department of Cell and Molecular Biology at the Medical College of Georgia in Augusta, Georgia.

\section{REFERENCES}

1. Pagnier J, Mears JG, Dunda-Belhodja 0, Schaefer-Rego KE, Beldjord G, Nagel RL, Labie D: Evidence for the multicentric origin of the sickle cell hemoglobin gene in Africa. Proc Natl Acad Sci USA 81:1771, 1984

2. Nagel RL, Fabry ME, Pagnier J, Zohoun I, Wajcman H, Baudin V, Labie D: Hematologically and genetically distinct forms of sickle cell anemia in Africa. The Senegal type and the Benin type. N Engl J Med 312: 880,1985 
3. Nagel RL, Rao SK, Dunda-Belkhodja 0, Connolly MM, Fabry ME, Georges $A$, Krishnamoorthy $R$, Labie $D$ : The hematological characteristics of sickle cell anemia bearing the Bantu haplotype. The relationship between $G_{Y}$ and $H b F$ level. Blood 69:1026, 1987

4. Ojwang PJ, Ogada T, Beris P, Hattori Y, Lanclos KD, Kutlar A, Kutlar F, Huisman THJ: Haplotypes and a globin gene analyses in sickle cell anaemia patients from Kenya. Br J Haematol 65:211, 1987

5. Kulozik AE, Wainscoat JS, Serjeant GR, Kar BC, Al-Awamy B, Essan GJF, Falusi AG, Haque SK, Hilali AM, Kate S, Ranasinghe WAEP, Weatherall DJ: Geographical survey of $\beta S$ globin gene haplotypes: Evidence for an independent Asian origin of the sickle cell mutation. Am J Hum Genet 39: 239, 1986

6. Miller BA, 0livieri $N$, Salameh M, Ahmed M, Antognetti $G$, Huisman THJ, Nathan DG, Orkin SH: Molecular analysis of the high-hemoglobin $F$ phenotype in Saudi Arabian sickle cell anemia. N Engl J Med 316:244, 1987

7. Lapoumeroulie $C$, Dunda 0 , Trabuchet $G$, Mony-Lobe $M$, Labie $D$, Elion J, Krishnamoorthy R: A novel sickle cell gene of yet another origin in Africa: The Cameroon type. B1ood 74:63a, 1989 (abstr, supp 1)

8. Antonarakis SE, Boehm CD, Serjeant GR, Theisen CE, Dover GW, Kazazian HH Jr: Origin of the ${ }_{\beta} S$ globin gene in blacks; the contribution of recurrent mutation or gene conversion or both. Proc Natl Acad Sci USA $81: 853,1984$

9. Hattor Y, Kutlar A, Kutlar F, McKie VC, Huisman THJ: Haplotypes of $\beta^{S}$ chromosomes among patients with sickle cell anemia from Georgia. Hemoglobin 10:623, 1986

10. Kutlar A, hattori $Y$, Bakioglu I, Kutlar F, Kamel K, Huisman THJ: Hematological observations on Arabian SS patients with a homozygosity or heterozygosity for a $\beta^{S}$ chromosome with haplotype \#31. Hemoglobin 9:545, 1985

11. Bakioglu I, Hattori $Y$, Kutlar A, Mathew C, Huisman THJ: Five adults with mild sickle cell anemia share a ${ }_{\beta} S$ chromosome with the same haplotype. Am J Hematol 20:297, 1985

12. Elion J, Berg PE, Trabuchet $G$, Schechter $A N$, Krishnamoorthy $R_{2}$ Labie D: Is polymorphism $0.5 \mathrm{~kb} 5^{\prime}$ to the $B-g l o b i n$ gene relevant to ${ }_{B} S$ gene expression? Blood 74:143a, 1989 (abstr, supp1)

13. Savagner $P$, Miyashita $T$, Yamada $Y$ : Two silencers regulate the tissue-specific expression of the collagen II gene. J Biol Chem 265:669, 1990

14. Devlin BH, Wefald FC, Kraus WE, Bernaard TS, Williams RS: Identification of a muscle-specific enhancer within the $5^{\prime}$ flanking region of the humlan myoglobin gene. J Biol Chem 264:13896, 1989

15. Berg PE, Williams DM, Qian RL, Cohen RB, Cao $S X$, Mittleman $M$, Schechter AN: A common protein binds to two silencers $5^{\prime}$ to the human B-globin gene. Nucleic Acids Res 17:8833, 1989

16. Gillies SD, Morrison SL, Oi VT, Tonegawa S: A tissue-specific transcription enhancer element is located in the major intron as a rearranged immunoglobulin heavy chain gene. Cel1 33:717, 1983

17. Banerji J, Olson L, Schaffner W: A lymphocyte-specific cellular enhancer is located downstream of the joining region in immunoglobulin heavy chain genes. Cell 33:729, 1983

18. Pandey NB, Chodchoy N, Liu T-J, Marzluff WF: Introns in histone genes alter the distribution of $3^{\prime}$ ends. Nucleic Acids Res 18:3161, 1990. 
19. Huang MT, Gorman CM: Intervening sequences increase efficience of RNA $3^{\prime}$ processing and accumulation of cytoplasmic RNA. Nucleic Acids Res 18:937, 1990.

20. Collis $P$, Antoniou $M$, Grosveld $F$ : Definition of the minimal requirements within the human $\beta$-globin gene and dominant control region for high level expression. EMBO J 9:233, 1990

21 Poncz M, Solowiejczk D, Harpel B, Mory Y, Schwartz E, Surrey S: Construction of human gene libraries from small amounts of peripheral blood: Analysis of B-like globin genes. Hemoglobin 6:27, 1982

22. Sanger $F$, Nicklen $S$, Coulson AR: DNA sequencing with chain terminating inhibitors. Proc Nat1 Acad Sci USA 74:5463, 1977

23. Saiki RK, Gelfand DH, Stoffel S, Scharf SJ, Higuchi R, Horn GT, Mullis KB, Erlich HA: Primer-directed enzymatic amplification of DNA with a thermostable DNA polymerase. Science 239:487, 1988

24. Gonzalez-Redondo JM, Stoming TA, Lanclos KD, Gu YC, Kutlar A, Kutlar F, Nakatsuji T, Deng B, Han IS, Mckie VC, Huisman THJ: Clinical and genetic heterogeneity in Black patients with homozygous $B$-thalassemia from the Southeastern United States. Blood 72:1007, 1989

25. Lanclos KD, Michael SK, Gu Y-C, Howard EF, Stoming TA, Huisman THJ: Transient chloramphenicol acetyltransferase expression of the $G_{\gamma}$ globin gene $\left.5^{\prime}-f\right]$ anking regions containing substitutions of $C_{+} T$ at position $-158,6 \rightarrow A$ at position -161 , and $T \rightarrow A$ at position -175 in $K 562$ cells. Biochim Biophys Acta 1008:109, 1989

26. Gonzalez-Redondo JM, Stoming TA, Kutlar A, Kutlar F, Lanclos $K D$, Howard EF, Fei YJ, Aksoy M, Altay 6 , Gurgey A, Basak AN, Efremov GD, Petkov G, Huisman THJ: A C + T substitution at nt -101 in a conserved DNA sequence of the promoter region of the $\beta-g l o b i n$ gene is associated with "silent" $\beta$-thalassemia. Blood 73:1705, 1989

27. Slightom JL, Blechl AE, Smithies 0: Human fetal $G_{\gamma}$ and $A_{Y}$ globin genes: Complete nucleotide sequences suggest that DNA can be exchanged between these duplicated genes. CE11 21:627, 1988

28. Stoeckert CJ Jr, Collins FS, Weissman SM: Human fetal globin DNA sequences suggest novel conversion event. Nucleic Acids Res 12:4469, 1984

29. Bouhassira EE, Lachman H, Krishnamoorthy R, Labie D, Nagel RL: A gene conversion located $5^{\prime}$ to the $A_{Y}$ gene in linkage disequilibrium with the Bantu haplotype in sickle cell anemia. J Clin Invest 83:2070, 1989

30. Month SR, Wood RW, Trifill is PT, Orchowski PJ, Sharon B, Ballas SK, Surrey S, Schwartz E: Analys is of the $5^{\prime}$ flanking regions of the garma globin genes from major African haplotype backgrounds associated with sickle cell disease. J Clin Invest 85:364, 1990

31. Stolle CA, Penny LA, Ivory S, Forget BG, Benz EJ Jr: Sequence analysis of the $\gamma$ globin gene locus from a patient with the deletion form of hereditary persistence of fetal hemoglobin. Blood 75:499, 1990

32. Shen SH, Slightom JL, Smithies 0: A history of the human fetal globin gene duplication. Ce11 26:191, 1981

33. Gilman JG, Huisman THJ: DNA sequence variation associated with elevated fetal $G_{Y}$ globin production. Blood $66: 783,1985$

34. Petes T, Fink GR: Gene conversions between repeated genes. Nature $300: 216,1982$

35. Bouhassira EE, Nagel RL: A 6-bp deletion $5^{\prime}$ to the $G_{\gamma}$ globin gene in ${ }_{B} S$ chromosomes bearing the Bantu haplotype. Am $J$ Hum Genet 47:161, 1990 
36. Ulrich MJ, Ley TJ: Function of normal and mutated $\gamma$-globin gene promoters in electroporated K562 erythroleukemia cells. Blood 75:990, 1990 


\section{.}


CHAPTER 3b

\title{
CERTAIN MUTATIONS OBSERVED IN THE 5' SEQUENCES OF THE $\mathbf{6}_{\boldsymbol{r}}$ - AND $A_{Y}$ GLOBIN GENES OF ${ }_{B} S$ CHROMOSOMES ARE SPECIFIC FOR CHROMOSOMES HITH MAJOR HAPLOTYPES
}

\author{
A.J. Dimovski, C. Oner, S. Agarwal, Y-C. Gu, L-H. Gu, \\ F. Kutlar, K.D. Lanclos, and T.H.J. Huisman \\ Department of Cell and Molecular Biology \\ Medical College of Georgia, Augusta, GA 30912-2100, USA
}

(Adapted from: Acta Haematol., 85:79-87, 1991)

\begin{abstract}
In this paper we describe the distribution of some specific sequence differences in the $5^{\prime}$ flanking regions of the $A_{Y}$ - and $G_{Y}$-globin genes from 100 Black adult and 57 newborn SS patients from the Southeastern United States, from 76 individuals with $A S, S-\beta$-thal, SC, AC, or A-B-thal, and from 31 normal individuals. Haplotypes for all adult individuals have been previously determined using various restriction endonucleases. The DNA samples were amplified, dot-blotted, and hybridized with 32p-labeled specific oligonucleotide probes. All 134 chromosomes with haplotype \#19 were positive for the $6+T$ substitution at position $-657\left(A_{Y}\right)$, while 132 were also positive for the $C_{\boldsymbol{C}} \mathbf{G}$ mutation at $-369\left(\mathrm{G}_{\boldsymbol{\gamma}}\right)$. The three specific changes for the chromosome with haplotype \#20 were found on al1 54 chromosomes with this haplotype. The $C_{0} T$ mutation at $-1585^{\prime}$ to $G_{\gamma}$ was present on all 41 chromosomes with haplotype \#3, and on two chromosomes with a related atypical haplotype. Normal and B-thal chromosomes with each of these substitutions had the same $5^{\prime}$ subhaplotype as ${ }_{B} S$ haplotypes $\# 19$ or $\# 20$, respectively. The close relationship between the occurrence of specific mutations and the haplotype of $\beta S$ chromosomes makes the determination of these haplotypes with specific oligonucleotide probes attractive with respect to time and expense.
\end{abstract}




\section{INTRODUCTION}

There is considerable evidence that the ${ }_{\beta} S$ mutation resulting in the synthesis of $\mathrm{Hb} \mathrm{S}$ has occurred independently on at least five different genetic backgrounds (1-4). With the use of multiple restriction enzymes that recognize specific polymorphisms scattered along the $B$-globin gene cluster, five major haplotypes have been defined that are linked to the ${ }_{B}^{S}$ gene. They have been named Benin, Bantu or CAR, Senegal, Saudi ArabianIndian, and Cameroon or $A_{Y} T$, and have been numbered as $\# 19, \# 20, \# 3$, \#31, and $\# 17$, respectively $(2,5)$. The Benin haplotype is most frequently observed among SS patients from West Africa $(1,6)$ and Turkey (7). The Bantu haplotype is found mainly in Central Africa and Kenya $(1,8,9)$, while the Senegal haplotype is restricted to the northwest coast of Africa $(1,6)$. The Asian origin of the ${ }_{B} S$ mutation has been linked to haplotype \#31; this ${ }_{B} S$ chromosome was discovered among the SS patients from the eastern part of Saudi Arabia and from India $(10)$. The Cameroon haplotype is linked to the $B S$ chromosome carrying an $A_{Y}{ }^{T}$ variant (5) and is present anong the patients from the west coast of Africa (4).

Haplotypes \#19, \#20, and \#3 are the major haplotypes present in the Black SS patients from the Southeastern United States and Jamaica $(2,5)$. The different $H b F$ levels and the different percentages of $G_{Y}$ chains observed among the SS patients with different haplotypes have prompted a search for specific changes in the $5^{\prime}$ flanking regions of the fetal globin genes present on these chromosomes. Chromosomes with haplotype \#31 were of particular interest because of the high $\mathrm{Hb} F$ levels $(20-35 \%)$ in SS patients with this haplotype and the high $G_{y}$ percentage $(n 70 \%)$. Moreover, mild clinical symptoms are associated with this type (11-13). Sequencing data for about 450 bp of the $5^{\prime}$ flanking regions of both $G_{y}$ and $A_{Y}$ have shown only a $C+F$ substitution at position $-1585^{\prime}$ to the $G_{Y}$ gene (14). The same mutation has been found on the ${ }_{B} S$ chromosome with haplotype $\# 3$, on a number of $B$-thal chromosomes from the Mediterranean and Far East areas $(3,15,16)$, and on normal chromosomes (17); it appears that this mutation is not solely responsible for the increase in the $H b F$ production in these SS patients. Two other mutations have been reported: A C F substitution at position $-2715^{\prime}$ to $A_{Y}$ on a chromosome with haplotype $\# 20(18)$, and an $A+G$ substitution at position $-3095^{\prime}$ to $G_{\gamma}$ on a chromosome with haplotype \#19 (19). We have previously sequenced $1.3 \mathrm{~kb}$ segments of DNA located $5^{\prime}$ to the ${ }^{G_{\gamma}}$ and $A_{\gamma}$-globin genes from chromosomes defined by the five major haplotypes, i.e. \#19, \#20, \#3, \#31, and \#17, and have observed specific differences, as listed in Fig. $3 b / 1(20)$. Here we describe the distribution of some of these specific mutations among the ${ }_{\beta} S, \beta$-thal, ${ }_{\beta} C$, and normal chromosomes, and evaluate the use of testing for these mutations in the identification of particular haplotypes.

\section{SUBJECTS AND METHODS}

One hundred adult and 57 newborn SS patients, 76 individuals with either $H b A S, H b S-\beta$-thal, $H b S C, H b A C$, or $H b A-\beta$-thal, and 31 nomal individuals (AA) have been evaluated. All subjects were Black and from the Southeastern United States. The adults have been studied extensively, 
and hematological data have been published before $(5,17)$; the diagnosis for the newborn babies was based on data by IEF, cation exchange HPLC, and occasionally, on data obtained by family studies. Haplotypes were defined by nine polymorphic restriction endonuclease sites (Hinc II $5^{\prime}$ to $\varepsilon$; Xmn I $5^{\prime}$ to $G_{\gamma}$; Hind III at $G_{\gamma}$ and $A_{\gamma}$; Hinc II at $\phi \beta$ and $3^{\prime}$ to it; Ava II at $\beta$; Hpa I and Bam HI $3^{\prime}$ to $\beta$ ) and were determined with procedures routinely in use in our laboratories (21).

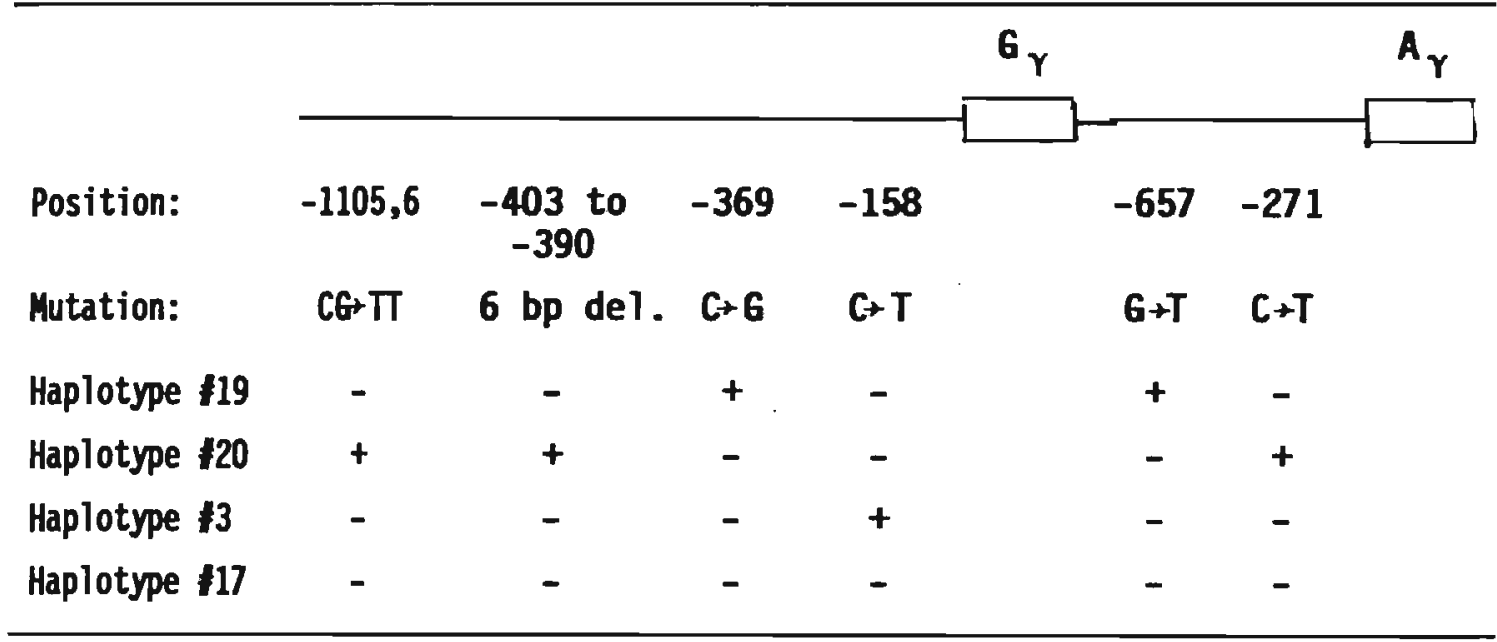

FI6. $3 b / 1$. Specific differences in the sequences of the $5^{\prime}$ flanking regions of the $G_{\gamma}$ - and $A_{\gamma}$-globin genes for ${ }_{B} S$ chromosomes with four different haplotypes; + and - indicate the presence or absence of a particular mutation. Haplotypes are numbered according to Antonarakis et al (2) and Hattori et al (5). The sequences of the $G_{\gamma}$ and $A_{\gamma}$ flanking regions for haplotypes $\# 3$ and $\# 31$ are identical.

Although DNA samples were available from many adults, it was necessary to recollect blood from several individuals. DNA was isolated from peripheral white cells by the method of Poncz et al (22). For the specific amplification of the $G_{\gamma}$ and $A_{\gamma} 5^{\prime}$ flanking regions two sets of primers were used. The direct $5^{\prime}$ primer was specific for either the $\mathrm{G}_{\gamma}$ or $A_{\gamma} 5^{\prime}$ flanking sequence, while a common $3^{\prime}$ reverse primer was used. Sequences and positions of the amplification primers and of the oligonucleotide probes used in the studies are given in Ref. 20 . The procedures for amplification and dot-blot analysis are given el sewhere (23-26).

\section{RESULTS}

Table $3 b / 1$ lists the results of the hybridization experiments for $252{ }_{\beta} S$ chromosomes. A11 134 B $S$ chromosomes, previously determined as having haplotype \#19, were positive for the $G+T$ substitution at position $-6575^{\prime}$ to the $A_{\gamma-g l o b i n}$ gene, while all but two were found to be positive for the $C+6$ substitution at position $-3695^{\prime}$ to the $G_{\gamma}$ gene. None of the chromosomes with other major haplotypes showed a positive result with these probes. 
TABLE 3b/1. Specific Changes in the $G_{\gamma}$ and $A_{\gamma} 5^{\prime}$ Flanking Regions of $252{ }_{B} S$ Chromosomes With Known Haplo-

\begin{tabular}{|c|c|c|c|c|c|c|c|c|c|c|c|c|c|}
\hline \multicolumn{2}{|c|}{$\begin{array}{l}\text { Specific Probes } \\
\text { for Haplotypes --> }\end{array}$} & \multicolumn{4}{|l|}{$\# 19$} & \multicolumn{6}{|l|}{$\# 20$} & \multicolumn{2}{|c|}{$13 \& \mid 31$} \\
\hline $\begin{array}{l}\text { Haplo- } \\
\text { types }\end{array}$ & $\begin{array}{l}\text { No. of } \\
\text { Chroms. } \\
\text { Tested }\end{array}$ & $\begin{array}{l}A_{Y} \\
(-657) \\
6 \\
-\end{array}$ & $\begin{array}{l}T \\
+\end{array}$ & $\begin{array}{l}G_{Y} \\
\text { (- } \\
C \\
-\end{array}$ & $\begin{array}{l}6 \\
+\end{array}$ & $\begin{array}{l}\text { A }_{Y} \\
(-271) \\
\mathbf{C} \\
-\end{array}$ & $\begin{array}{l}T \\
+\end{array}$ & $\begin{array}{l}G \\
\text { G } \\
\text { CG } \\
-\end{array}$ & $\begin{array}{l}-1106) \\
+ \\
+\end{array}$ & $\begin{array}{l}G_{6} \text { bp } \\
-\end{array}$ & $\begin{array}{l}\text { del.) } \\
+\end{array}$ & $\begin{array}{l}G_{Y} \\
C \\
C \\
-\end{array}$ & $\begin{array}{l}T \\
+\end{array}$ \\
\hline$\# 19$ & 134 & & 134 & 2 & 132 & 134 & & 134 & & 134 & & 134 & \\
\hline$\# 20$ & 54 & 54 & & 54 & & & 54 & & 54 & & 54 & 54 & \\
\hline$\# 3$ & 41 & 41 & & 41 & & 41 & & 41 & & 41 & & & 41 \\
\hline$\# 31$ & 2 & 2 & & 2 & & 2 & & 2 & & 2 & & & 2 \\
\hline$\# 17$ & 8 & 8 & & 8 & & 8 & & 8 & & 8 & & 8 & \\
\hline Others & 13 & 8 & 5 & 9 & 4 & 11 & 2 & 11 & 2 & 11 & 2 & 11 & 2 \\
\hline Total & 252 & & & & & & & & & & & & \\
\hline
\end{tabular}

a The presence or absence of a specific mutation is indicated by + and - .

b Numbering system is according to Antonarakis et al (2) and others are a series of eight atypical haplotypes. 
All 54 chromosomes with haplotype \#20 carried three mutation which are characteristic for a chromosome with this haplotype, namely $C \rightarrow T$ at position $-2715^{1}$ to $A_{\gamma}, C G \rightarrow \pi$ at positions -1105 and -1106 to $G_{\gamma}$, and $a$ 6 bp deletion between positions -403 to $-3905^{\prime}$ to $G_{Y}$. The $C+T$ substitution at position $-1585^{\prime}$ to the $G_{Y}$ gene that creates and $X m n$ I restriction site was present only on the $B S$ chromosomes with haplotypes $\# 3$ and $\# 31$, as reported previously (5).

The results obtained for the 13 DNA samples with atypical haplotypes are listed in Table 3b/2. Three DNA samples with haplotype \#19a were positive for the haplotype-\#19-specific probes in the $G_{\gamma}$ and $A_{Y} 5^{\prime}$ flanking regions; it has the same $5^{\prime}$ subhaplotype $\left[5^{\prime}-\ldots\right.$ \#19. A fourth DNA sample with the same 5 ' subhaplotype had a positive result only with the probe specific for the $6+T^{\prime}$ substitution at $-6575^{\prime}$ to the $A_{\gamma}$ gene. A fifth DNA sample with a different $5^{\prime}$ subhaplotype [5' $\left.-+^{+}+3^{\prime}\right]$ was positive for both probes.

The two DNA samples with the atypical ${ }_{\beta} S$ haplotype \#20a were positive for the three haplotype-\#20-specific mutations in the $G_{Y}$ and $A_{Y} 5^{\prime}$ flanking regions; the $5^{\prime}$ subhaplotype $\left[5^{\prime}-\ldots+\ldots-3^{\prime}\right]$ was also the same as in haplotype \#20. None of the other DNA samples were positive for any of the listed mutations. Two of the samples were positive for the $\rightarrow T$ substitution at position $-1585^{\prime}$ to the $G_{\gamma}$ gene; their haplotypes differ from haplotype \#3 in only one position (Table $3 b / 2$ ).

The 20 chromosomes with the ${ }_{B} C$ mutation and haplotype $C-1$ [5' - + $\left.-++/++3^{\prime}\right]$ were negative for all probes 1 isted in Table $3 b / 1$.

The possible presence of the six mutations was also evaluated for 32 chromosomes with a $\beta$-thal mutation; the data are listed in Table $3 \mathrm{~b} / 3$. Twenty-three chromosomes had haplotype $A$ (which is similar to $B S$ haplotype $\# 3\left[5^{\prime}-++-++/++3^{\prime}\right]$ and either the $A+6$ B-thal mutation at position -29 or the $C+T$ - $B$-thal mutation at position -88 ; two chromosomes were not analyzed. The five mutations which are specific for ${ }_{\beta} S$ haplotypes $\# 19$ and \#20 were absent, while, as expected, the $C+T$ mutation at position -158 was present. Negative results were also obtained for the three DNA samples with haplotype $C\left[5^{\prime}+----/+++3^{\prime}\right]$ and the $B$-thal mutations listed in Table 3b/3. Five chromosomes with haplotype B [5' $\ldots+-+++\ldots+$ $\left.3^{\prime}\right]$, which is the same as $B S$ haplotype $\# 19$, were positive for the -657 $(6+T)(A y)$ mutation but only one chromosome carried the $C+6$ mutation at -369 of $G_{\gamma}$. The one chromosome with the atypical haplotype $\left[5^{\prime}-{ }_{-}+-\right.$ $\left.+/-++3^{\prime}\right]$ was positive for the three probes specific for the ${ }_{B} S$ haplotype $-\# 20$-related mutations.

Similar data for 105 B A chromosomes of normal Black individuals are listed in Table $3 \mathrm{~b} / 4$; details of the $5^{\prime}$ subhaplotypes are also included. All mutations were absent except for the $6 \rightarrow T$ substitution at position -657 $\left(A_{\gamma}\right)$ and the $C+6$ mutation at position $-369\left(G_{\gamma}\right)$ for DNA samples with the $5^{\prime}$ subhaplotype [5' - . - + $\left.3^{\prime}\right]$ which is the same as the ${ }_{B} S$ haplotype \#19. However, eight of the 26 chromosomes with this subhaplotype were negative for the $C+G$ substitution at position $-369\left(G_{Y}\right)$ and positive for the $6+7$ mutation at position $-657\left(A_{Y}\right)$. None of the normal chromosomes had mutations specific for haplotype \#20, including the one chromosome with the same $5^{\prime}$ subhaplotype. 
TABLE 3b/2. The Presence or Absence of Specific Substitutions in the 5' Flanking Regions of the GY- and $A_{\gamma-G 10 b i n}$ Genes for $13{ }_{B} S$ Chromosomes With Atypical Haplotypes

\begin{tabular}{|c|c|c|c|c|c|c|c|c|c|c|c|c|c|c|c|c|c|c|c|c|}
\hline \multirow[b]{3}{*}{$\begin{array}{l}\text { Haplo- } \\
\text { type* }\end{array}$} & \multirow[b]{3}{*}{$\mathrm{Hc}$} & \multirow[b]{3}{*}{$x$} & \multirow{2}{*}{\multicolumn{2}{|c|}{$5^{\prime}$}} & \multirow{2}{*}{\multicolumn{6}{|c|}{$3^{\prime}$}} & \multicolumn{10}{|c|}{$\begin{array}{l}\text { Specific Probes for Haplotypes: } \\
\# 19\end{array}$} \\
\hline & & & & & & & & & & & \multicolumn{2}{|c|}{${ }_{(-657)}^{A}$} & \multicolumn{2}{|c|}{$\stackrel{G_{r}}{(-369)}$} & \multicolumn{2}{|c|}{${ }_{(-271)}^{A}$} & \multicolumn{2}{|c|}{$\begin{array}{l}\text { Gr } \\
(-1105 ; \\
-1106)\end{array}$} & \multicolumn{2}{|c|}{$\begin{array}{l}\mathrm{G}_{\gamma} \\
\left(\begin{array}{l}6 \\
\text { del. }\end{array}\right)\end{array}$} \\
\hline & & & $\mathrm{Hd}$ & $\mathrm{Hd}$ & $\mathrm{Hc}$ & $\mathrm{Hc}$ & $A$ & $\mathrm{Hp}$ & $B$ & $\begin{array}{l}\text { No. of } \\
\text { Chroms. }\end{array}$ & $\begin{array}{l}6 \\
-\end{array}$ & $\begin{array}{l}T \\
+\end{array}$ & C & $\begin{array}{l}\mathbf{6} \\
+\end{array}$ & $\begin{array}{l}C \\
-\end{array}$ & $\begin{array}{l}T \\
+\end{array}$ & $\begin{array}{l}\text { CG } \\
-\end{array}$ & $\underset{+}{T}$ & - & + \\
\hline $19^{a}$ & - & - & - & - & - & + & + & 0 & - & 3 & & 3 & & 3 & 3 & & 3 & & 3 & \\
\hline$?$ & - & - & - & - & - & + & - & + & + & 1 & & 1 & 1 & & 1 & & 1 & & 1 & \\
\hline $20^{b}$ & - & - & + & - & - & + & - & 0 & + & 1 & & 1 & & 1 & 1 & & 1 & & 1 & \\
\hline $20^{a}$ & - & - & + & - & - & - & + & 0 & - & 2 & 2 & & 2 & & & 2 & & 2 & & 2 \\
\hline $19^{b}$ & + & - & - & - & - & + & + & 0 & + & 2 & 2 & & 2 & & 2 & & 2 & & 2 & \\
\hline$?$ & - & - & + & - & - & + & + & \pm & - & 2 & 2 & & 2 & & 2 & & 2 & & 2 & \\
\hline $3^{a}$ & - & + & + & - & + & - & + & $\mathbf{o}$ & + & 1 & 1 & & 1 & & 1 & & 1 & & 1 & \\
\hline \multicolumn{10}{|c|}{ Total number of chromosomes } & 13 & 8 & 5 & 9 & 4 & 11 & 2 & 11 & 2 & 11 & 2 \\
\hline
\end{tabular}


IABLE 3b/3. The Presence or Absence of Specific Changes in the $5^{\prime}$ Flanking Regions of the Gy- and A Globin Genes for 32 B-Thal Chromosomes

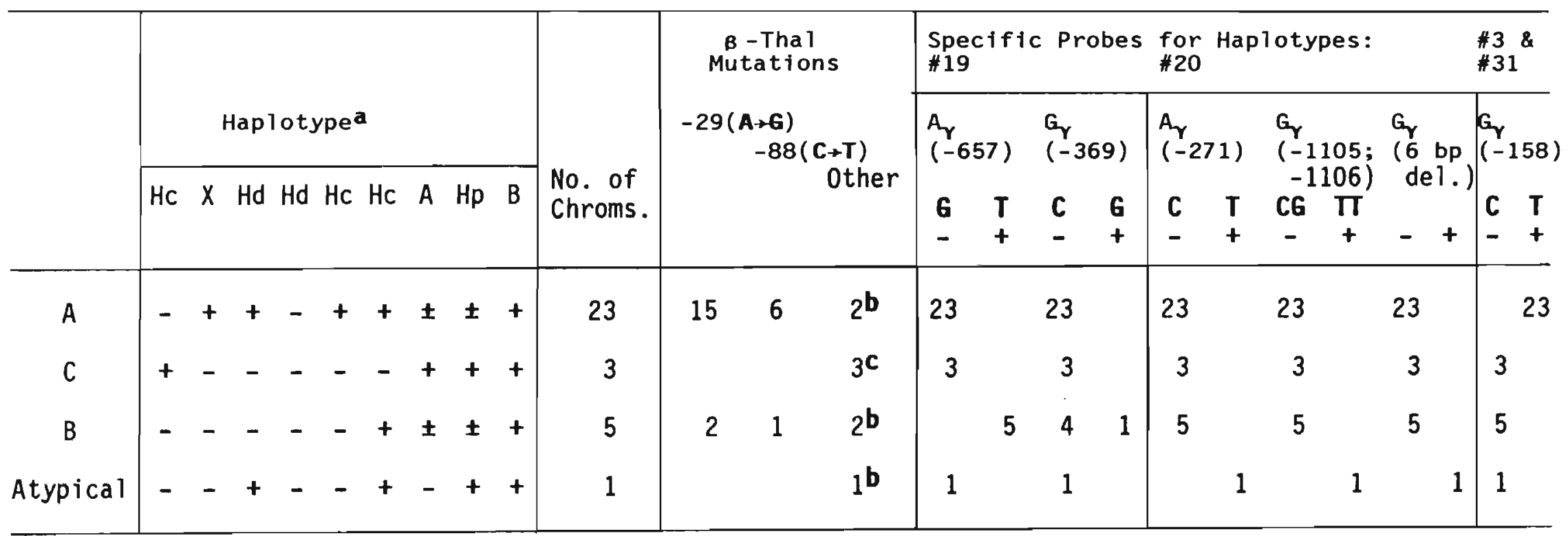

a From Hattori et al (5).

b Unknown.

C Two chromosomes: IVS-I-110 (G+A); one with the 1393 bp deletion. 
TABLE 3b/4. The Presence or Absence of Specific Changes in the $5^{\prime}$ Flanking Regions of the $G_{\gamma}$ and $A_{\gamma}$ Genes of 105 Chromosomes of Normal Black Persons

\begin{tabular}{|c|c|c|c|c|c|c|c|c|c|c|c|c|c|c|c|c|}
\hline \multirow[b]{3}{*}{$\mathrm{HC}$} & \multirow[b]{3}{*}{$x$} & \multirow{3}{*}{$\begin{array}{l}5^{\prime} \\
\mathrm{Hd}\end{array}$} & \multirow{2}{*}{\multicolumn{3}{|c|}{ Subhaplotype }} & \multirow{3}{*}{$\begin{array}{l}\text { No. of } \\
\text { Chroms. }\end{array}$} & \multicolumn{9}{|c|}{$\begin{array}{l}\text { Specific Probes for Haplotypes: } \\
\# 20\end{array}$} & \\
\hline & & & & & & & \multicolumn{2}{|c|}{$\begin{array}{l}A_{\gamma} \\
(-657)\end{array}$} & \multicolumn{2}{|c|}{$\stackrel{G}{Y}_{(-369)}$} & \multicolumn{2}{|c|}{${ }_{(-271)}^{A}$} & \multicolumn{2}{|c|}{$\begin{array}{l}\mathrm{Gr}_{\mathrm{Y}} \\
(-1105 ; \\
-1106)\end{array}$} & \multicolumn{2}{|l|}{$\begin{array}{l}G_{y} \\
(6 \text { bp } \\
\text { del. })\end{array}$} \\
\hline & & & Hd & Hc & $\mathrm{Hc}$ & & $\begin{array}{l}6 \\
-\end{array}$ & $\begin{array}{l}T \\
+\end{array}$ & C & $\begin{array}{l}6 \\
+\end{array}$ & $\begin{array}{l}\text { C } \\
-\end{array}$ & $\begin{array}{l}T \\
+\end{array}$ & CG & $\begin{array}{c}T T \\
t\end{array}$ & & + \\
\hline- & - & - & - & - & + & 26 & & 26 & 8 & 18 & 26 & & 26 & & 26 & \\
\hline - & + & + & - & + & + & 17 & 17 & & 17 & & 17 & & 17 & & 17 & \\
\hline+ & - & - & - & - & - & 12 & 12 & & 12 & & 12 & & 12 & & 12 & \\
\hline- & - & - & - & - & - & 12 & 12 & & 12 & & 12 & & 12 & & 12 & \\
\hline - & - & + & + & - & + & 7 & 7 & & 7 & & 7 & & 7 & & 7 & \\
\hline+ & + & - & + & + & + & 6 & 6 & & 6 & & 6 & & 6 & & 6 & \\
\hline- & - & + & - & - & + & 6 & 6 & & 6 & & 6 & & 6 & & 6 & \\
\hline+ & - & - & - & - & + & 6 & 6 & & 6 & & 6 & & 6 & & 6 & \\
\hline - & + & + & - & + & - & 3 & 3 & & 3 & & 3 & & 3 & & 3 & \\
\hline - & + & + & + & + & + & 2 & 2 & & 2 & & 2 & & 2 & & 2 & \\
\hline - & + & + & - & - & + & 1 & 1 & & 1 & & 1 & & 1 & & 1 & \\
\hline+ & - & + & - & - & + & 1 & 1 & & 1 & & 1 & & 1 & & 1 & \\
\hline+ & 12 kb & + & - & - & - & 1 & 1 & & 1 & & 1 & & 1 & & 1 & \\
\hline - & - & + & - & - & - & 1 & 1 & & 1 & & 1 & & 1 & & 1 & \\
\hline+ & - & - & - & + & + & 1 & 1 & & 1 & & 1 & & 1 & & 1 & \\
\hline+ & - & + & + & - & + & 1 & 1 & & 1 & & 1 & & 1 & & 1 & \\
\hline - & - & + & - & + & + & 1 & 1 & & 1 & & 1 & & 1 & & 1 & \\
\hline - & $12 \mathrm{~kb}$ & + & + & + & - & 1 & 1 & & 1 & & 1 & & 1 & & 1 & \\
\hline Tot & 1 numb & er o & chro & some : & & 105 & 79 & 26 & 87 & 18 & 105 & & 105 & & 105 & \\
\hline
\end{tabular}


In order to evaluate the possible use of selected probes for the determination of $\beta S$ haplotypes among Black patients, cord blood samples from 57 babies with SS have been studied; their haplotypes had not been determined before. The $1.3 \mathrm{~kb} \mathrm{G}_{Y} 5^{\prime}$ flanking region was amplified and hybridized with three probes, namely that for haplotype $\# 19(-369, \mathbf{C}+\mathbf{6})$, that for haplotype \#20 ( 6 bp deletion between positions -403 to -390 ) and that for haplotype $\# 3(-158, C+T)$. The characterization of the $B S$ chromosome with haplotype \#17 (Cameroon or $A_{\gamma}^{\top}$ ) was based upon the presence of the $A_{\gamma}^{\top}$ chain detected by HPLC $(27,28)$. The frequencies of the four haplotypes among the ${ }_{\beta} S$ chromosomes of the 57 newborns, as determined by dot-blot analyses, closely resembled those observed for the adult SS patients from Georgia (Table $3 b / 5$ ).

TABLE 3b/5. Frequencies of the Four ${ }_{\beta} S$ Haplotypes Among Adult and Newborn SS Patients From Georgia and South Carolina

\begin{tabular}{|c|c|c|c|}
\hline \multirow[t]{2}{*}{ Haplotype } & \multicolumn{2}{|c|}{ Adult SS } & \multirow{2}{*}{$\begin{array}{c}\text { Newborn SS } \\
\text { Dot-Blot } \\
\text { Procedure }\end{array}$} \\
\hline & $\begin{array}{c}\text { Conventional } \\
\text { Procedure }\end{array}$ & $\begin{array}{l}\text { Dot-blot } \\
\text { Procedure }\end{array}$ & \\
\hline$\# 19$ & $134(53.2)$ & $132(52.4)$ & $71(62.3)$ \\
\hline$\# 20$ & $54(21.4)$ & $54(21.4)$ & $17(14.9)$ \\
\hline$\# 3^{a}$ & $43(17.1)$ & $43(17.1)$ & $15(13.2)$ \\
\hline$\# 17^{b}$ & $8(3.2)$ & $8(3.2)$ & $5(4.4)$ \\
\hline others & $13(5.1)$ & $15(5.9)$ & $6(5.3)$ \\
\hline $\begin{array}{l}\text { Total number of } \\
\text { chromosomes }\end{array}$ & $252(100.0)$ & $252(100.0)$ & $114(100.0)$ \\
\hline
\end{tabular}

Figures in parentheses are percent values.

a Haplotypes \#3 and \#31 cannot be distinguished by the dot-blot procedure; type \#31, however, has never been observed among Blacks from the SE-USA.

b Haplotype \#17 (Cameroon or $A_{\gamma}{ }^{\top}$ ); the identification of this haplotype is based upon the presence of the $A_{\boldsymbol{\gamma}} T$ chain as determined by reversed phase HPLC $(27,28)$.

\section{DISCUSSION}

The present survey among American $B$ lack subjects with ${ }_{B} S,{ }_{B} C, B$-thal, and ${ }^{A} A$ chromosomes for mutations which had been detected in the $5^{\prime}$ flanking regions of $G_{\gamma-}$ and $A_{\gamma-g l o b i n}$ genes on the ${ }_{\beta} S$ chromosomes of five $S S$ patients with five distinct haplotypes (2) provides data indicating that selected mutations are specific for certain chromosomes and can be used for the typing of $\beta S$ chromosomes. We showed that one of these, the $6+T$ substitution at position $-6575^{\prime}$ to $A_{\gamma}$, was present on all $134{ }_{B} S$ chromosomes defined as haplotype \#19. Four of five ${ }_{B} S$ chromosomes with an atypical haplotype that had this $6+T_{\text {T mution at }}-657$, also had a $5^{\prime}$ subhaplotype which was identical to that of haplotype \#19. This finding 
suggests a haplotype \#19 for these four ${ }_{B} S$ chromosomes which, however, was modified by a recombination event involving the $3^{\prime}$ part of the $\beta$-globin locus. Another chromosome with haplotype $\left[5^{\prime}-+_{-++}++3^{\prime}\right]$ also carried this $6 \cdot-1$ at -675 (A ${ }_{Y}$ ) mutation but differed from haplotype \#19 in the Hind III site in the ${ }^{\gamma}$ IVS-II region (haplotype \#20 b in Table $3 b / 1)$. Since this chromosome also had the haplotype-\#19-specific $C+6$ mutation at -369 in the ${ }^{6} Y 5^{\prime}$ flanking region, it seems possible that the sequence in the Hind III site in the $\mathrm{G}_{\gamma}$ IVS-II was introduced by a short gene conversion. As many as 26 of the 105 normal chromosomes (25\%) and five of the 32 B-thal chromosomes (14\%) were found to be positive for the

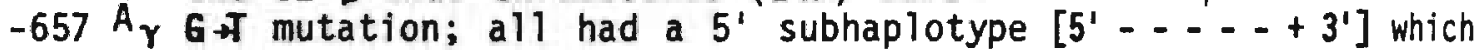
is the same as that of haplotype \#19. This observation suggests that a chromosome with haplotype \#19 carried the $-657 \quad 6+T$ substitution prior to the introduction of the $\beta^{S}$ mutation.

The $C+6$ substitution at position $-3695^{\prime}$ to the $G_{\gamma}$ gene was present on all but three of the $\beta S$ chromosomes which had the $G+T$ mutation at -657 $\left(A_{\gamma}\right)$. The three exceptions concerned two $B S$ chromosomes with haplotype \#19 and one with an atypical haplotype which, however, had the same $5^{\prime}$ subhaplotype [5' - - - + 3'] as haplotype \#19. The same pattern, namely a positive result for the $6 \cdot T$ substitution at position $-657\left(A_{Y}\right.$ ) and negative result for the $C+6$ substitution at $-369\left(G_{Y}\right)$, was observed in one-third of the narmal chromosomes (eight of 26 chromosomes tested) with the same subhaplotype [5' - . - + 3'] and in four of the five $B$-thal chromosomes with this subhaplotype (Tables $3 b / 3$ and $3 b / 4$ ). This observation suggests two possibilities. First, two different chromosomes with haplotype \#19 were present prior to an independent introduction of the $\beta^{S}$ or $\beta$-thal mutations. Second, only chromosome with haplotype \#19 existed with $T$ at -657 in $\dot{A}_{\gamma}$ and $\mathbf{G}$ at -369 in $G_{\gamma}$, and the $\beta S$ and $\beta$-thal mutations occurred on this chromosome. A subsequent gene conversion would then result in a $6 * \mathcal{C}$ mutation at $-369\left(G_{\gamma}\right)$ on either the normal, the $\beta S$ or the $\beta$-thal chromosome. It is noteworthy that the SS patients with haplotype $\# 19$ with $T$ at -657 in $A_{\gamma}$, and either $C$ or $G$ at -369 in $G_{\gamma}$ have similar levels of fetal $\mathrm{Hb}$.

Three substitutions have been found on a $\beta^{S}$ chromosome with haplotype $\# 20$, namely $C_{-}+\mathrm{T}$ at position $-271\left(A_{Y}\right), C G+T$ at positions -1105 and -1106 $\left(G_{\gamma}\right)$, and the 6 bp deletion between positions -403 and $-390\left(G_{Y}\right.$ ) (Fig. 3b/1). These changes are highly specific for this chromosome. Two chromosomes with a so-called atypical haplotype were also positive for these changes; they share the same $5^{\prime}$ subhaplotype [5' - + - - 3'] with haplotype \#20. None of the other $\beta S$ or normal chromosomes carried these mutations, and only one of the $\beta$-thal chromosomes had these changes; the $5^{1}$ subhaplotype of this chromosome was again the same as that of haplotype \#20 except for the Hinc II polymorphism $3^{\prime}$ to $\psi \beta$. The distribution of these changes among the normal chromosomes in Central and East Africa is not known.

Chromosomes defined by the haplotype \#17 (Cameroon or $A_{\gamma}^{\top}$ ) did not show any specific sequence difference from the reference sequences (20). All chromosomes were found to be negative for the substitutions specific for haplotypes $\# 19$ or \#20, as well as for the $C+T$ substitution at position $-1585^{\prime}$ to the $G_{Y}$ gene. 
The occurrence of certain sequence differences in the $5^{\prime}$ flanking region of the fetal globin genes on $\beta^{S}$ chromosomes with specific haplotypes makes the hybridization of amplified DNA with these selected probes an attractive method for the determination of these haplotypes. This is amply demonstrated by the survey of ${ }_{B} S$ haplotypes in the DNA of the 57 newborn babies with SS; the data listed in Table $3 \mathrm{~b} / 5$ showed a remarkably close relationship between the frequencies of the five $B S$ haplotypes among the two groups of SS patients that were tested. Thus, the use of these specific probes will prove valuable in the further screening of chromosomes from Africa, the Mediterranean and Caribbean, and will enhance our understanding of the geographical origin and distribution of the various haplotypes, particularly that of haplotype \#19.

Acknowledgements. This study was supported by USPHS Research Grant HLB-41544. This is contribution \#1262 from the Department of Cell and Molecular Biology at the Medical College of Georgia in Augusta, GA, USA.

\section{REFERENCES}

1. Pagnier, J., Mears, J.G., Dunda-Be1khodja, O., Schaefer-Rego, K.E., Beldjord, C., Nagel, R.L., and Labie, D.: Evidence for the multicentric origin of the sickle cell hemoglobin gene in Africa. Proc. Natl. Acad. Sci. USA, 81:1771, 1984.

2. Antonarakis, S.E., Boehm, C.D., Serjeant, G.R., Theisen, C.E., Dover, G.J., and Kazazian, H.H., Jr.: Origin of the ${ }_{B} S$ globin gene in Blacks; the contribution of recurrent mutation or gene conversion or both. Proc. Natl. Acad. Sci. USA, 81:853, 1984.

3. Kulozik, A.E., Kar, B.C., Satapathy, R.K., Sariot, G.R., and Weatherall, D.J.: Fetal hemoglobin levels and ${ }_{B} S$ haplotypes in an Indian population with sickle cell disease. Blood, 69:1742, 1987.

4. Lapoumeroulie, C., Dunda, 0., Trabuchet, G., Mony-Lobe, M., Labie, D., Elion, J., and Krishnamoorthy, R.: A novel sickle gene of yet another origin in Africa: The Cameroon type. Blood, 74:63a, 1989 (Suppl. 1).

5. Hattori, Y., Kutlar, F., Kutlar, A., McKie, V.C., and Huisman, T.H.J.: Haplotypes of $\beta S$ chromosomes among patients with sickle cell anemia from Georgia. Hemoglobin, 10:623, 1986.

6. Nagel, R.L., Fabry, M.E., Pagnier, J., Zohoun, I., Wajcman, H., Baudin, V., and Labie, D.: Hematologically and genetically distinct forms of sickle cell anemia in Africa. N. Eng1. J. Med., 312:880, 1985.

7. Aluoch, J.R., Kilins, Y., Aksoy, M., Yuregir, G.T., Bakioglu, I., Kutlar, A, Kutlar, F., and Huisman, T.H.J.: Sickle cell anaemia among Eti-Turks: Haematological, clinical and genetic observations. $\mathrm{Br}$. J. Haematol., 64:45, 1986.

8. Nagel, R.L., Rao, S.K., Dunda-Belkhodja, 0., Connolly, M.M., Fabry, M.E., Georges, A., Krishnamoorthy, R., and Labie, D.: The hematologic characteristics of sickle cell anemia bearing the Bantu haplotype: The relationship between $G_{Y}$ and $H b F$ level. Blood, 69:1026, 1987. 
9. Ojwang, P.J., Ogada, T., Beris, P., Hattori, Y., Lanclos, K.D., Kutlar, A., Kutlar, F., and Huisman, T.H.J.: Haplotypes and a globin gene analysis in sickle gell anaemia patients from Kenya. Br. J. Haema tol., 65:211, 1987.

10. Kulozik, A.E., Wainscoat, J.S., Serjeant, G.R., Kar, B.C., Al-Awamy, B., Essan, G.J.F., Falusi, A.G., Haque, S.K., Hilali, A.M., Kate, S., Ranasinghe, W.A.E.P., and Weathera11, D.J.: Geographical survey of ${ }_{B} S$ globin gene haplotypes: Evidence for an independent Asian origin of the sickel cell mutation. Am. J. Hum. Genet., 39:239, 1986.

11. Bakioglu, I., Hattori, Y., Kutlar, A., Mathew, C., and Huisman, T.H.J.: Five adults with mild sickle cell anemia share a $\beta^{S}$ chromosome with the same haplotype. Am. J. Hematol., 20:297, 1985.

12. Kutlar, A., Hattori, Y., Bakioglu, I., Kutlar, F., Kamel, K., and Huisman, T.H.J.: Hematological observations on Arabian SS patients with a homozygosity or heterozygosity for a $\beta^{S}$ chromosome with haplotype \#31. Hemoglobin, 9:454, 1985.

13. Miller, B.A., Salameh, M., Ahmed, M., Olivieri, N., Antognetti, G., Orkin, S.H., Huisman, T.H.J., and Nathan, D.G.: Analysis of Hemoglobin $F$ production in Saudi-Arabian families with sickle cell anemia. Blood, 70:716, 1987.

14. Miller, B.A., Olivieri, N., Salameh, M., Ahmed, M., Antognetti, G., Huisman, T.H.J., Nathan, D.G., and Orkin, S.H.: Molecular analysis of the hig-Hemoglobin $F$ phenotype in Saudi Arabian sickle cell anemia. N. Engl. J. Med., 316:244, 1987.

15. Gilman, J.G. and Huisman, T.H.J.: DNA sequence variations associated with elevated fetal $G_{Y}$ production. Blood, 66:783, 1985.

16. Lable, D., Dunda-Belkhodja, O., Rouabhi, F., Pagnier, J., Ragusa, A., and Nage 1, R.L.: The -158 site $5^{\prime}$ to the $G_{Y}$ expression. Blood, $66: 1463,1985$.

17. Hattori, Y., Kutlar, F., Mosley, C.J., Mayson, S.M., and Huisman, T.H.J.: Association of the level of $G_{\gamma}$ chain in the fetal hemoglobin of normal adults with specific haplotypes. Hemoglobin, 10:185, 1986.

18. Bouhassira, E.E., Lachman, H., Krishnamoorthy, R., Labie, D., and Nagel, R.L.: A gene conversion located $5^{\prime}$ to the $A_{\gamma}$ gene in linkage disequilibrium with the Bantu haplotype in sickle cell anemia. J. Clin. Invest., 83:2070, 1989.

19. Month, S.R., Wood, R.W., Trifillis, P.T., Orchowski, P.J., Sharon, B., Ballas, S.K., Surrey, S., and Schwartz, E.: Analysis of 5' flarlking regions of the gamma globin genes from major African haplotype backgrounds associated with sickle cell disease. J. Clin. Invest., $85: 364,1990$.

20. Lanclos, K.D., Oner, C., Dimovski, A.J., Gu, Y-C., and Huisman, T.H.J.: Sequence variations in the $5^{\prime}$ flanking and IVS-II regions of the $G_{\gamma}$-and $A_{\gamma}$ globin genes of $B S$ chromosomes with five different haplotypes. Blood, 77:2488, 1991 .

21. Harano, T., Reese, A.L., Ryan, R., Abraham, B.L., and Huisman, T.H.J.: Five haplotypes in Black B-thalassaemia heterozygotes: Three are associated with high and two with low $G_{Y}$ values in fetal haemoglobin. Br. J. Haemato1., 59:333, 1985.

22. Poncz, M., Solowiejczyk, D., Harpe1, B., Mory, Y., Schwartz, E., and Surrey, S.: Construction of human gene libraries from small amounts of peripheral blood: Analysis of B-like globin genes. Hemoglobin, $6: 27,1982$. 
23. Saiki, R.K., Gelfand, D.H., Stoffel, S., Scharf, S.J., Higuchi, R., Horn, G.T., Mullis, K.B., and Erlich, H.A.: Primer-directed enzymatic amplification of DNA with a thermostable DNA polymerase. Science, 239:487, 1988.

24. Diaz-Chico, J.C., Yang, K.G., Yang, K.Y., Efremov, D.G., Stoming, T.A., and Huisman, T.H.J.: The detection of $B-g l o b i n$ gene mutations in $\beta$-thalassemia using oligonucleotide probes and amplified DNA. Biochim. Biophys. Acta, 949:43, 1988.

25. Gonzalez-Redondo, J.M., Stoming, T.A., Lanclos, K.D., Gu, Y.C., Kutlar, A., Kutlar, F., Nakatsuji, T., Deng, B., Han, I.S., McKie, V.C., and Huisman, T.H.J.: Clinical and genetic heterogeneity in Black patients with homozygous B-thalassemia from the Southeastern United States. Blood, 72:1007, 1988.

26. Gonzalez-Redondo, J.M., Stoming, T.A., Kutlar, F., Kutlar, A., Mckie, V.C., McKie, K.M., and Huisman, T.H.J.: Severe $H b S B^{\circ}$-thalassaemia with a $T+C$ substitution in the donor splice site of the first intron of the B-globin gene. Br. J. Haematol., 71:113, 1989.

27. Shelton, J.B., Shelton, J.R., and Schroeder, W.A.: High performance liquid chromatographic separation of globin chains on a large-pore $C_{4}$ column. J. Liq. Chromatogr., 7:1969, 1984.

28. Kutlar, F., Kutlar, A., and Huisman, T.H.J.: Separation of normal and abnormal hemoglobin chains by reversed-phase high-performance liquid chromatography. J. Chromatography., 357:147, 1986. 

CHAPTER 3C

\section{${ }_{\beta} S$ HAPLOTYPES IN VARIOUS HORLD POPULATIONS}

C. Oner1, A.J. Dimovski1, N.F. Olivieri2, 6. Schiliro ${ }^{3}$, J.F. Codrington 1,4 , S. Fattoum 1,5, A.D. Adekile1,6, R. Oner 1, G.T. Yuregir7, C. Altay8, A. Gurgey8, R.B. Gupta1,9, V.B. Jogessar 10 , M.N. Kitundu1,11, D. Loukopoulos ${ }^{12}$, G.P. Tamagnini13, M.L.S. Ribeiro13, F. Kutlarl, L-H. Gul, K.D. Lanclos' ${ }^{1}$, and T.H.J. Hui sman 1 (Affiliations are listed on the next page)

(Adapted from: Hum. Genet., 89:99-104, 1992)

\section{ABSTRACT}

We have determined the ${ }_{\beta} S$ haplotypes in 709 patients with SS disease, 30 with SC disease, 91 with S- $\beta$-thal, and in $322 \mathrm{Hb} S$ heterozygotes from 14 different countries. The methodology concerned the detection of mutations in the promoter sequences of the ${ }^{b_{\gamma}}$ and $A_{\boldsymbol{\gamma}}$ globin genes through dotblot analysis of amplified DNA with 32p-labeled probes, and an analysis of isolated $\mathrm{Hb} F$ by reversed phase high performance liquid chromatography to detect the presence of the $A_{\gamma}^{\top}$ chain [A ${ }^{\top} 75$ (E19)Ile $\rightarrow$ Thr] that is characteristic for haplotype \#17 (Cameroon). The results support previously published data obtained with conventional methodology (reviewed by Schroeder et al, 1990) indicating that the $\boldsymbol{B} S$ gene arose separately in different locations. The present methodology has the advantage of being relatively inexpensive and fast, allowing the collection of a vast body of data in a short period of time. It also offers the opportunity of identifying unusual $\beta^{S}$ haplotypes that may be associated with a milder expression of the disease. The numerous blood samples obtained from many SS patients living in different countries made it possible to compare their hematological data; such information is included (as average values) for 395 SS patients with haplotypes $19 / 19$, for two with haplotypes $17 / 17$, for 50 with haplotypes $20 / 20$, for two with haplotypes $3 / 3$, and for 37 with haplotypes $31 / 31$. Some information on haplotype characteristics of normal B $A$ chromosomes is also presented. 
1. Department of Biochemistry and Molecular Biology, Medical College of Georgia, Augusta, GA 30912-2100, U.S.A.

2. Department of Hematology, The Hospital for Sick Children, Toronto, Canada M5G $1 \times 8$

3. Department of Pediatric Hematology, University of Catania, 95125 Catania, Sicily, Italy

4. Academisch Ziekenhuis, Paramaribo, Suriname

5. Laboratoire de Biochemie, Hopital d'Enfants, Place Bab-Saadoun, Tunis, Tunisie

6. Department of Pediatrics, Obafemi Awolowo University, Ile-Ife, Nigeria

7. Department of Biochemistry, University of Cukurova, Adana, Turkey

8. Children's Medical Center, Hacettepe University, Ankara, Turkey

9. Regional Medical Center for Tribals, Jabalpur 482003, India

10. Department of Haematology, King Edward VIII Hospital, P.O. Congella, Durban, Republic of South Africa

11. Yuma Foundation Laboratories, Iramba District, Kinampanda, Tanzania

12. First Department of Medicine, University of Athens, Laikon Hospital, GR 11527 Athens, Greece

13. Department of Hematology, Centro Hospitalar, P-3000 Coimbra, Portugal

\section{INTRODUCTION}

SS is one of the most common hereditary diseases; its hematological characteristics and clinical severity are variable and are influenced by a number of factors, including the simultaneous presence of an a-thal, variations in $\mathrm{Hb} \mathrm{F}$ level, and the haplotype background that is linked to the B-globin gene (for review see Nagel and Ranney, 1990). There is also convincing evidence that the ${ }_{\beta} S$ mutation arose in Africa and Saudi ArabiaIndia on at least five different types of chromosomes; these chromosomes have distinct haplotypes that are linked to the 8 gene and are numbered $17,19,20,3$, and 31 , respectively, and are also known as the Cameroon, Benin, Bantu or CAR (Central African Republic), Senegal, and Saudi ArabiaIndia types, respectively (for review see Nagel and Ranney, 1990; Schroeder et a 1, 1990).

Determination of these haplotypes is based upon the presence or absence of different restriction sites (reviewed in Hattori et al, 1986). We recently detected certain mutations within the promoter regions of the $G_{\gamma}$ and $A_{\gamma-g l o b i n}$ genes and in the IVS-II of the $A_{\gamma-g l o b i n}$ gene that are characteristic for the listed haplotypes (Lanclos et al, 1991; Dimovski et a1, 1991). A ${ }_{B} S$ chromosome with haplotype \#19 has two specific mutations, one in each of the promoter sequences, namely $-369(C+6) G_{y}$ and $-657(G+T)$ $A_{\gamma}$, that with haplotype \#20 has a double base mutation, a highly characteristic 6 bp deletion in the ${ }^{G} Y$ promoter, and a single base pair mutation in the $A_{Y}$ promoter, while that with haplotype $\# 17$ has none of these but carries a $T \rightarrow C$ mutation at $C D 75\left(A_{\gamma}\right)$ leading to the synthesis of the $A_{\gamma} T$ chain (75 Ile + Thr) (Ricco et al, 1976). The ${ }_{B} S$ chromosome with either haplotypes \#3 or \#31 cannot be distinguished from each other by this procedure. Both have only the $C+T$ mutation at -158 in the $G_{Y}$ promoter that results in a high level of $G_{\gamma}$ chains (Gilman and Huisman, 1984) (Table $3 c / 1)$. Differentiation between the two is based on the ethnic/racial background of the individual and, in certain cases, on the presence or absence 
of the Hinc II site $5^{\prime}$ to the $\varepsilon$ gene and the Bam HI site $3^{\prime}$ to the $\beta$-globin gene. Moreover, it has been reported (Berg et al, 1991) that the +ATA/-T configuration at position -530 to the $B-g$ lobin gene is characteristic for haplotype \#31. To distinguish haplotypes \#3 and \#31, a DNA segment between positions -724 and +27 relative to the Cap site of the $\beta-g l o b i n g e n e$ is amplified and hybridized with probes specific for this change in sequence and for the normal sequence (for methodology, see Wong et a1, 1989). The methodology is relatively fast; numerous amplified DNA samples are placed on a nylon membrane and are hybridized sequentially with the probes for the four mutations in the $G_{Y}$ promoter or the two in the $A_{Y}$ promoter. Identification of haplotype \#17 requires either an additional amplification involving the $A_{r}$ globin gene and hybridization with a probe specific for the $T * C$ mutation at $C D 75$, or the isolation of $H b F$ from the red cells and characterization of the types of $\gamma$ chain by reversed phase HPLC (the latter approach was used in this study). An added benefit of the methodology is that it allows the selection of unusual ${ }_{B} S$ haplotypes that are different from the five major types and often associated with a milder form of the disease.

TABLE 3c/1. Mutations Characteristic for ${ }_{B} S$ Chromosomes With Specific Haplotypes

\begin{tabular}{l|ccccc}
\hline \multirow{2}{*}{ Mutations } & \multicolumn{5}{|c}{ Haplotype } \\
\cline { 2 - 6 } & $\# 17$ & $\# 19$ & $\# 20$ & $\# 3$ & $\# 31$ \\
\hline$-1106 / 05(G C+\pi)\left(G_{\gamma}\right)$ & - & - & + & - & - \\
6 bp deletion $(-C T T A A)\left(G_{\gamma}\right)$ & - & - & + & - & - \\
$-369(C+6)\left(G_{\gamma}\right)$ & - & + & - & - & - \\
$-158(C+T)\left(G_{\gamma}\right)$ & - & - & - & + & + \\
$-657(G+T)\left(A_{\gamma}\right)$ & - & + & - & - & - \\
$-271(C+T)\left(A_{\gamma}\right)$ & - & - & + & - & - \\
Hb F high $G_{\gamma}(>60 \%)$ & - & - & - & + & + \\
Hb F with $A_{\gamma} T$ & + a & - & - & $-b$ & $-b$ \\
\hline
\end{tabular}

a Due to a $T+C$ mutation at $C D 75$ of the ${ }^{A}$ rglobin gene.

b Differentiation of haplotypes \#3 and \#31 is based on racial/ethnic background of the subject and/or on the presence or absence of a Hinc II site $5^{\prime}$ to the $\varepsilon$ gene (haplotype \#31: +; \#3: -). + : the mutation is present; - : the mutation is absent.

Since the development of this methodology, we have reconfirmed some of the $\beta^{S}$ haplotypes previously determined in our laboratory with the restriction endonuclease method, and all current data were obtained with the new approach. In the present communication, we describe our experience with haplotyping a large number of ${ }_{\beta} S$ chromosomes from patients living in 14 different countries using the new approach. Details of hematology and clinical features for most of the patients have either been published or will be published elsewhere. The data for patients from the United States (Hattori et al, 1986; Kutlar et a), 1985), Kenya (0jwang et al, 
1987), and Tunisia (Abbes et a1, 1991; Fattoum et al, 1991) in the present study are a reconfirmation of already published information, while the others represent new and ongoing analyses.

\section{MATERIALS AND METHODS}

Blood samples from 1152 individuals were collected in vacutainers with EDTA as anticoagulant. The subjects came from 14 different countries and had SS, SC disease, AS, or Hb S- - -thal; the $\beta$-thal alleles were not identified.

The United States patients were mainly Blacks from the Georgia area of the Southeastern USA, but included one Arab family. The Canadian patients were Caribbean immigrants; those from Tunisia and Syria were Arabs, while those from Turkey were Eti-Turks from Cukurova province. The Italian and Greek patients were Caucasians from Sicily and Athens, respectively. The Surinamese were Blacks with varying ancestries, and those from India belong to the Gond tribal groups from the central part of the country. The Kenyans, Tanzanians, and Angolans were Bantus, while the Nigerians were representative of various ethnic groups (mainly Ibo, Hausa, and Yoruba) and were drawn from eight different centers. All patients were attending sickle cell clinics in their various countries but the Angolans were residents of Portugal and attending the Central Hospital in Coimbra. All were in steady state, i.e. not in crisis or any other acute illness at the time of blood collection. Less than $10 \%$ of the patients were related, but the AS individuals were mostly relatives of the SS patients.

A1] blood samples were kept, as much as possible, at $4^{\circ} \mathrm{C}$ for varying periods of time, and were shipped or carried in wet ice by fast air service and by different authors to Augusta, GA. Most samples reached the laboratory more than three weeks after collection. However, complete blood counts were obtained within a day of collection for samples from the United States, Canada, Portugal, Italy, Greece, and South Africa. These were done either locally at the centers of collection, or in the laboratory in Augusta, GA.

Hematological data were obtained using an automated cell counter. All samples were analyzed by IEF (Righetti et al, 1986) and by cation exchange HPLC (Bisse and Wieland, 1988; Kutlar et a1, 1990), for the quantitation of $\mathrm{Hb} \mathrm{F}$ and $\mathrm{Hb} \mathrm{A}_{2}$. $\mathrm{Hb} F$ was isolated by DEAE-cellulose chromatography (Schroeder and Huisman 1980) and its $Y$ chain composition was determined by reversed phase HPLC (Shelton et al, 1984; Kutlar et al, 1986).

DNA was isolated from the blood samples with the method of Poncz et al (1982). For the majority of the samples the $\beta^{S}$ mutation was confirmed by dot-blot analysis, hybridizing amplified DNA with a 32p-labeled oligonucleotide probe that is specific for the $A+T$ mutation at CD 6 (Gl $u+V a 1)$ of the B-globin gene. Segments of 1350 bp of both the $G_{\gamma}$ - and $A_{\gamma-g l o b i n}$ genes were amplified from genomic DNA with $5^{\prime}$ direct oligonucleotide primers specific for $G_{\gamma}$ and $A_{\gamma}$ and a common $3^{\prime}$ reverse primer. Aliquots of these amplified DNA samples were blotted onto nylon membranes and hybrid- 
ized to the specific $5^{\prime}$ end-labeled oligonucleotide probes. Sequences and positions of the amplification primers as well as the methodology used has been detailed in earlier studies (Lanclos et al, 1991; Dimovski et al, 1991).

\section{RESULTS}

The Subjects. A total of $1861{ }_{B} S$ chromosomes have been analyzed; $509{ }_{\beta} 5$ chromosomes came from patients of North and South America, 791 from Africa, 426 from Mediterranean countries, and 135 from Indian donors. The largest group of patients were from Nigeria, followed by the United States, and Turkey. There was no significant sex difference in the whole population.

The $\beta^{S}$ Haplotypes (Table $3 \mathrm{c} / 2$ ). Four different haplotypes were present in the North and South American donors; the frequency of haplotype \#19 was the highest in all three groups, followed by haplotype \#20, \#3, and \#17. The high frequency of haplotype \#20 among patients from Surinam was striking. The seven chromosomes with haplotype \#31 were from four members of an Arab family, described before (Kutlar et al, 1985). As many as $36{ }_{\beta} S$ chromosomes had atypical haplotypes; some of these are presently under study.

TABLE 3c/2. Number of Patients With Hemoglobinopathies Participating in This Study and Their $\mathrm{S} S$ Haplotypes

\begin{tabular}{|c|c|c|c|c|c|c|c|c|c|c|c|}
\hline \multirow[b]{2}{*}{ Country } & \multirow[b]{2}{*}{ SS } & \multirow[b]{2}{*}{ SC } & \multirow[b]{2}{*}{ AS } & \multirow[b]{2}{*}{$S_{B} T h$} & \multirow[b]{2}{*}{$\begin{array}{c}{ }^{B} \mathrm{~S} \\
\text { Chroms. }\end{array}$} & \multicolumn{6}{|c|}{ Hap lotypes } \\
\hline & & & & & & 19 & 17 & 20 & 3 & 31 & Others \\
\hline $\begin{array}{l}\text { USA (SE) } \\
\text { Canada } \\
\text { Surinam }\end{array}$ & $\begin{array}{r}147 \\
21 \\
14\end{array}$ & $\begin{array}{r}13 \\
11 \\
1\end{array}$ & $\begin{array}{r}41 \\
5 \\
45\end{array}$ & $\begin{array}{r}23 \\
3 \\
3\end{array}$ & $\begin{array}{r}371 \\
61 \\
77\end{array}$ & $\begin{array}{r}205 \\
30 \\
41\end{array}$ & $\begin{array}{r}13 \\
8 \\
2\end{array}$ & $\begin{array}{r}71 \\
7 \\
23\end{array}$ & $\begin{array}{r}56 \\
8 \\
2\end{array}$ & $\begin{array}{l}7 \\
0 \\
0\end{array}$ & $\begin{array}{r}19 \\
8 \\
9\end{array}$ \\
\hline $\begin{array}{l}\text { Kenya } \\
\text { Tanzania } \\
\text { Nigeria } \\
\text { Angolad }\end{array}$ & $\begin{array}{r}55 \\
14 \\
294 \\
6\end{array}$ & $\begin{array}{l}0 \\
0 \\
2 \\
0\end{array}$ & $\begin{array}{r}1 \\
13 \\
30 \\
4\end{array}$ & $\begin{array}{l}0 \\
0 \\
3 \\
0\end{array}$ & $\begin{array}{r}111 \\
41 \\
623 \\
16\end{array}$ & $\begin{array}{r}2 \\
0 \\
576 \\
2\end{array}$ & $\begin{array}{r}0 \\
0 \\
23 \\
0\end{array}$ & $\begin{array}{r}109 \\
41 \\
5 \\
14\end{array}$ & $\begin{array}{l}0 \\
0 \\
6 \\
0\end{array}$ & $\begin{array}{l}0 \\
0 \\
0 \\
0\end{array}$ & $\begin{array}{r}0 \\
0 \\
13 \\
0\end{array}$ \\
\hline $\begin{array}{l}\text { Tunisia } \\
\text { Sicily (Italy) } \\
\text { Greece } \\
\text { Turkey } \\
\text { Syria }\end{array}$ & $\begin{array}{r}35 \\
18 \\
0 \\
67 \\
2\end{array}$ & $\begin{array}{l}2 \\
0 \\
0 \\
1 \\
0\end{array}$ & $\begin{array}{r}37 \\
19 \\
14 \\
60 \\
5\end{array}$ & $\begin{array}{r}6 \\
15 \\
0 \\
19 \\
4\end{array}$ & $\begin{array}{r}115 \\
70 \\
14 \\
214 \\
13\end{array}$ & $\begin{array}{r}109 \\
70 \\
13 \\
206 \\
13\end{array}$ & $\begin{array}{l}0 \\
0 \\
0 \\
0 \\
0\end{array}$ & $\begin{array}{l}0 \\
0 \\
0 \\
0 \\
0\end{array}$ & $\begin{array}{l}0 \\
0 \\
1 \\
0 \\
0\end{array}$ & $\begin{array}{l}0 \\
0 \\
0 \\
1 \\
0\end{array}$ & $\begin{array}{l}6 \\
0 \\
0 \\
7 \\
0\end{array}$ \\
\hline $\begin{array}{l}\text { India } \\
\text { South Africa } \\
\text { (Indians) }\end{array}$ & $\begin{array}{r}36 \\
0\end{array}$ & $\begin{array}{l}0 \\
0\end{array}$ & $\begin{array}{r}45 \\
3\end{array}$ & $\begin{array}{r}12 \\
3\end{array}$ & $\begin{array}{r}129 \\
6\end{array}$ & $\begin{array}{l}0 \\
0\end{array}$ & $\begin{array}{l}2 \\
0\end{array}$ & $\begin{array}{l}0 \\
0\end{array}$ & $\begin{array}{l}0 \\
0\end{array}$ & $\begin{array}{r}127 \\
6\end{array}$ & $\begin{array}{l}0 \\
0\end{array}$ \\
\hline Total & 709 & 30 & 322 & 91 & 1861 & 1267 & 48 & 270 & 73 & 141 & 62 \\
\hline
\end{tabular}

a From subjects living in Portugal. 
The data from African patients fell into two groups. The Kenyan, Angolan, and Tanzanian $B S$ chromosomes had haplotype \#20, while those of Nigerian subjects had haplotype \#19 with $3.7 \%$ haplotype $\# 17,1.0 \%$ haplotype $\# 3$, and $0.8 \%$ haplotype $\# 20$. As many as 411 of the $426{ }_{B} S$ chromosomes (96.5\%) from the patients of Mediterranean descent had haplotype \#19; 13 ${ }_{B} 5$ chromosomes are in need of further characterization. All but two of the 135 Indian $\beta^{S}$ chromosomes had haplotype $\# 31$; the origin of two $\beta$ S chromosomes with haplotype $\# 17$ remains unclear.

The $\beta A$ and $\beta$-Thal Chromosomes. Dimovski et al (1991) reported the specific changes in the $5^{\prime}$ flanking regions of the $G_{\gamma}$ and $A_{\gamma}$ genes of 105 ${ }_{B} A$ chromosomes from normal Black individuals from the Southeastern United States. They found that 26 chromosomes were positive for the $-657 \quad 6+T$ (A ${ }_{\gamma}$ ) mutation, while 18 of these 26 chromosomes also had the $-3690-6(G)$ mutation; these two changes are specific for haplotype \#19. None were positive for haplotype \#20. In the same study it was observed that 23 of 32 chromosomes with a B-thal mutation had haplotype A (which is similar to the ${ }_{B} S$ haplotype \#3). Five chromosomes with haplotype $B$, which is similar to ${ }_{B} S$ haplotype \#19, were positive for the $-657 G+T\left(A_{\gamma}\right)$ mutation, but only one chromosome carried the $C \rightarrow 6$ mutation at $-369\left(G_{y}\right)$. One chromosome with an atypical haplotype in the study was positive for $\beta S$ haplotype \#20-related mutations.

of the $30{ }_{B} A$ chromosomes from Nigerian AS individuals in the present study, seven (23.3\%) were positive for haplotype \#19-specific mutations, while one (3.3\%) was positive for haplotype \#20 mutations. The $\beta$-thal chromosome, present in three members of one family, had haplotype \#20-specific mutations. Among the 13 B A chromosomes from Tanzania, four had haplotype \#19-specific mutations. Information on $\beta A$ chromosomes from the other countries is not available.

Hematological and $\mathbf{H b}$ Composition Data. Complete and satisfactory data could be obtained for 486 SS patients (Table 3c/3). As many samples were collected more than three weeks prior to the analyses (Surinam, Nigeria, Tanzania, Syria, India) the PCV, MCV, and MCHC values should be viewed with reservation. The most severe anemia is found among SS patients with haplotype $20 / 20$, followed by the patients with haplotype $19 / 19$. The hematological data from 37 SS patients with haplotype $31 / 31$ indicated mild to moderate anemia with an average $\mathrm{Hb}$ level of $210.0 \mathrm{~g} / \mathrm{dl}$. Hb $F$ values varied considerably but were generally below $10.0 \%$ for SS patients with the $19 / 19,17 / 17$, and $20 / 20$ haplotypes. Higher values with high $G_{\gamma}$ values were observed in all SS patients with haplotype $3 / 3$ and $31 / 31$; detailed information about the Indian SS patients will be presented elsewhere (Gupta et al, 1991).

\section{DISCUSSION}

Two recent reviews (Schroeder et al, 1990; Nagel and Ranney, 1990) have summarized the $B S$ haplotype data and have estimated the approximate boundaries of the four major haplotypes; the Senegal type \#3 is present in Atlantic West Africa, the Benin type (\#19) in Central West Africa, the 


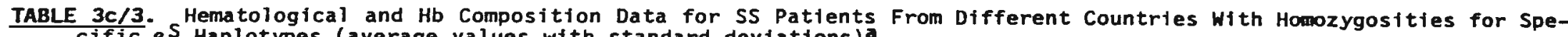
cific ${ }_{B} S$ Haplotypes (average values with standard deviations)

\begin{tabular}{|c|c|c|c|c|c|c|c|c|c|c|c|c|}
\hline $\begin{array}{l}\text { Haplo- } \\
\text { type }\end{array}$ & Country & n & $\begin{array}{c}\text { Age } \\
(y r s)\end{array}$ & $\underset{g / d l}{H b}$ & $\begin{array}{l}\mathrm{PCV} \\
1 / 1\end{array}$ & $\frac{\mathrm{RBC}}{10^{12} / 1}$ & $\underset{f l}{M C V}$ & $\begin{array}{c}\mathrm{MCH} \\
\mathrm{Pg}\end{array}$ & $\begin{array}{l}\mathrm{MCHC} \\
\mathbf{g} / \mathrm{d}]\end{array}$ & $\begin{array}{l}A_{2} \\
26\end{array}$ & $\underset{\mathbf{g} b}{F}$ & $\begin{array}{l}G_{Y C} \\
{ }_{X C}\end{array}$ \\
\hline $19 / 19$ & $\begin{array}{l}\text { USA } \\
\text { Surinam } \\
\text { Nigeria } \\
\text { Tunisia } \\
\text { Italy } \\
\text { Turkey } \\
\text { Syria }\end{array}$ & $\begin{array}{r}24 \\
5 \\
249 \\
35 \\
18 \\
62 \\
2\end{array}$ & $\begin{array}{c}7.9 \\
(6.4) \\
10.5 \\
(4.8) \\
9.7 \\
(6.0) \\
14.3 \\
(6.7) \\
11.2 \\
(7.1) \\
10.0 \\
(4.2) \\
4 \\
20 \\
20\end{array}$ & $\begin{array}{r}8.80 \\
(1.0) \\
8.30 \\
(1.4) \\
7.53 \\
(1.4) \\
8.20 \\
(1.2) \\
7.55 \\
(1.6) \\
8.40 \\
(1.8) \\
7.20 \\
9.20\end{array}$ & $\begin{array}{c}0.250 \\
(0.030) \\
0.294 \\
(0.048) \\
0.282 \\
(0.045) \\
0.250 \\
(0.041) \\
0.240 \\
(0.039) \\
0.250 \\
(0.060) \\
0.225 \\
0.255\end{array}$ & $\begin{array}{c}3.02 \\
(0.57) \\
2.85 \\
(0.35) \\
2.76 \\
(0.65) \\
2.53 \\
(0.31) \\
2.47 \\
(0.37) \\
2.72 \\
(0.65) \\
2.73 \\
2.61\end{array}$ & $\begin{array}{c}84.0 \\
(9.0) \\
102.5 \\
(8.7) \\
103.7 \\
(13.3) \\
98.8 \\
(8.1) \\
97.2 \\
(7.5) \\
91.9 \\
(7.0) \\
82.0 \\
98.0\end{array}$ & $\begin{array}{l}29.4 \\
(4.0) \\
28.8 \\
(2.7) \\
26.8 \\
(2.2) \\
32.4 \\
(3.1) \\
30.6 \\
(3.2) \\
30.7 \\
(2.1) \\
26.2 \\
35.2\end{array}$ & $\begin{array}{l}35.0 \\
(2.7) \\
28.2 \\
(1.8) \\
26.8 \\
(2.2) \\
32.8 \\
(2.6) \\
31.5 \\
(2.1) \\
34.2 \\
(2.0) \\
32.0 \\
36.1\end{array}$ & $\begin{array}{c}2.9 \\
(0.5) \\
3.2 \\
(1.0) \\
2.9 \\
(1.0) \\
2.9 \\
(1.1) \\
2.9 \\
(0.7) \\
2.7 \\
(0.6) \\
3.7 \\
3.1\end{array}$ & $\begin{array}{c}11.7 \\
(5.2) \\
9.3 \\
(4.4) \\
9.2 \\
(5.6) \\
7.6 \\
(2.9) \\
9.0 \\
(4.1) \\
9.8 \\
(4.0) \\
7.8 \\
9.2\end{array}$ & $\begin{array}{l}40.8 \\
(4.6) \\
42.4 \\
(4.0) \\
41.6 \\
(5.9) \\
36.5 \\
(4.3) \\
39.6 \\
(3.6) \\
44.0 \\
(4.1) \\
41.1 \\
40.0\end{array}$ \\
\hline $17 / 17$ & $\begin{array}{l}\text { USA } \\
\text { Nigeria }\end{array}$ & $\begin{array}{l}1 \\
1\end{array}$ & 12 & $\begin{array}{c}7.90 \\
=\end{array}$ & $\begin{array}{c}0.225 \\
=\end{array}$ & $\begin{array}{c}2.89 \\
=\end{array}$ & $\begin{array}{c}77.7 \\
-\end{array}$ & $\begin{array}{c}27.3 \\
-\end{array}$ & $\begin{array}{c}35.1 \\
-\end{array}$ & $\begin{array}{l}3.2 \\
3.1\end{array}$ & $\begin{array}{r}5.4 \\
14.1\end{array}$ & $\begin{array}{l}42.7 \\
49.2\end{array}$ \\
\hline $20 / 20$ & $\begin{array}{l}\text { USA } \\
\text { Surinam } \\
\text { Tanzania } \\
\text { Kenya } \\
\text { Angola }\end{array}$ & $\begin{array}{r}6 \\
3 \\
12 \\
25 \\
4\end{array}$ & $\begin{array}{l}9.8 \\
(4.1) \\
12.6 \\
(4.8) \\
10.7 \\
(6.5) \\
10.9 \\
(7.2) \\
9.3 \\
(5.0)\end{array}$ & $\begin{array}{r}8.20 \\
(0.9) \\
7.60 \\
(1.5) \\
6.42 \\
(1.3) \\
7.85 \\
(1.3) \\
7.30 \\
(0.5)\end{array}$ & $\begin{array}{c}0.210 \\
(0.020) \\
0.290 \\
(0.050) \\
0.247 \\
(0.050) \\
0.260 \\
(0.040) \\
0.207 \\
(-)\end{array}$ & $\begin{array}{c}2.55 \\
(0.29) \\
2.96 \\
(0.60) \\
2.27 \\
(0.49) \\
2.54 \\
(0.31) \\
2.70 \\
(0.23)\end{array}$ & $\begin{array}{c}84.5 \\
(7.1) \\
98.0 \\
(7.1) \\
108.8 \\
(14.4) \\
102.4 \\
(8.0) \\
88.3 \\
(6.4)\end{array}$ & $\begin{array}{l}31.8 \\
(3.2) \\
25.7 \\
(2.1) \\
28.8 \\
(4.9) \\
30.9 \\
(2.8) \\
30.5 \\
(2.4)\end{array}$ & $\begin{array}{l}37.5 \\
(1.4) \\
26.2 \\
(1.5) \\
26.0 \\
(1.7) \\
30.2 \\
(1.3) \\
35.3 \\
(1.0)\end{array}$ & $\begin{array}{l}2.5 \\
(0.35) \\
3.6 \\
(0.4) \\
\text { n.d. } \\
3.1 \\
(0.7) \\
\text { n.d. }\end{array}$ & $\begin{array}{c}12.1 \\
(6.4) \\
5.7 \\
(2.3) \\
8.6 \\
(3.4) \\
7.5 \\
(4.5) \\
2.7 \\
(2.3)\end{array}$ & $\begin{array}{l}41.3 \\
(3.8) \\
38.6 \\
(2.9) \\
44.0 \\
(3.6) \\
40.6 \\
(4.9) \\
\text { n.d. }\end{array}$ \\
\hline $3 / 3$ & USA & 2 & $\begin{array}{l}43 \\
15\end{array}$ & $\begin{array}{l}9.6 \\
8.2\end{array}$ & $\begin{array}{l}0.280 \\
0.300\end{array}$ & $\begin{array}{l}3.60 \\
3.11\end{array}$ & $\begin{array}{l}79.0 \\
78.0\end{array}$ & $\begin{array}{l}26.7 \\
26.4\end{array}$ & $\begin{array}{l}33.7 \\
33.5\end{array}$ & $\begin{array}{l}3.0 \\
3.3\end{array}$ & $\begin{array}{l}19.2 \\
14.0\end{array}$ & $\begin{array}{l}71.1 \\
71.2\end{array}$ \\
\hline $31 / 31$ & $\begin{array}{l}\text { USA } \\
\text { India }\end{array}$ & $\begin{array}{r}3 \\
34\end{array}$ & $\begin{array}{l}13.3 \\
(5.8) \\
12.1 \\
(8.2)\end{array}$ & $\begin{array}{c}10.1 \\
(1.4) \\
9.7 \\
(1.8)\end{array}$ & $\begin{array}{c}0.295 \\
(0.020) \\
0.281 \\
(0.038)\end{array}$ & $\begin{array}{c}3.78 \\
(0.12) \\
3.17 \\
(0.78)\end{array}$ & $\begin{array}{l}78.0 \\
(4.0) \\
88.6 \\
(7.0)\end{array}$ & $\begin{array}{l}26.7 \\
(2.7) \\
30.6 \\
(5.2)\end{array}$ & $\begin{array}{l}34.2 \\
(1.3) \\
34.5 \\
(1.4)\end{array}$ & $\begin{array}{c}1.2 \\
(0.3) \\
1.9 \\
(0.3)\end{array}$ & $\begin{array}{l}27.8 \\
(5.3) \\
23.2 \\
(5.9)\end{array}$ & $\begin{array}{l}64.9 \\
(1.3) \\
68.6 \\
(3.7)\end{array}$ \\
\hline
\end{tabular}

a The data for the US patients are from Hattori et al, 1986; Kutlar et al, 1985.

b By microchromatography (Schleider et al, 1977) or cation exchange HPLC (Bisse and Wieland, 1988; Kutlar et al, 1990).

C By reversed phase HPLC (Shelton et al, 1984; Kutlar et al, 1986). 
Bantu (CAR) type (\#20) in South-Central and Eastern Africa, while the Saudi Arabia-India type \#31 is restricted to the Indian subcontinent and the eastern section of the Arabian peninsula. The fifth type (\#17) is much more restricted, being observed mainly in the Eton ethnic group of Cameroon (Lapoumeroulie et al, 1989); it was originally observed among Blacks living in the Southeastern United States (Hattori et a1, 1986). The nearly exclusive occurrence of haplotype \#19 among SS patients in various Mediterranean countries suggest that this ${ }_{\beta} S$ chromosome was introduced from Central West Africa via Algeria, Tunisia, and Egypt.

The large body of data presented here supports these conclusions. The almost exclusive occurrence of one specific $\beta^{S}$ haplotype in patients from different countries (\#20 in Kenya, Angola, and Tanzania; \#19 in Nigeria; \#19 in all Mediterranean countries; \#31 in India) is most striking. The presence of haplotypes \#3 and \#17 among Nigerian SS patients is as expected; $B S$ haplotype \#3 is introduced from the west and \#17 from the east (Cameroon). The presence of haplotype $\# 20$ is also not surprising since it is generally agreed that Bantu migration originated around the Nigeria/Cameroon area (Nagel, 1984). Less evident is the origin of the two ${ }_{\beta} S$ haplotype $\# 17$ in two Indian tribal patients. The variation in the relative percentages of the African ${ }_{\beta} S$ haplotypes in American, Canadian (mainly immigrants from the Caribbean area), and Surinam patients likely reflects the origins of their predecessors; apparently, many slaves in South America were Bantus who carry the $\beta$

Recently, Bouhassira et al (1989) suggested the occurrence of a gene conversion in the $\beta S$ chromosome with haplotype \#20 that involves the replacement of the $A_{\gamma}$ sequence by a $G_{\gamma}$ sequence in the promoter of the $A_{\gamma}$ globin gene. The $5^{\prime}$ limit of the conversion is thought to be located between positions -306 and -271 (at position -271 the $C$ is replaced by a $T$ as in ${ }^{Y}$ ) and the $3^{\prime} 1$ imit between positions +25 (the $A$ is replaced by 6 ) and +1108 (the $T$ found in $A_{Y}$ is retained; the $G_{\gamma}$-globin gene has an $A$ at this position). The authors observed that this conversion is highly, but not exclusively, associated with haplotype \#20 because some normal chromosomes also appear to carry this change. Moreover, the frequency of the conversion, determined for 11 SS patients with a homozygosity for haplotype $\# 20$, was 0.82 . The characterization of the ${ }_{\beta} S$ chromosomes with haplotype \#20, 1isted in Table $3 c / 2$, is based upon the presence of changes in the $G$ and $A_{Y}$ promoters, including the $C+F$ mutation at position $-271\left(A_{\gamma}\right)$. All $270{ }_{\beta} S$ chromosomes with haplotype \#20 of the patients from the Southeastern United States, the Caribbean area (the Canadian patients), Surinam, and the African countries, carried that mutation, while the other $\beta S$ chromosomes, the $\beta A,{ }_{B} C$, and $\beta$-thal chromosomes, did not.

The PCR amplification method for mass screening of ${ }_{\beta} S$ haplotypes has the advantage over the restriction enzyme methodology of being fast, simple, and accurate, as was indicated by the excellent agreement between the data obtained with the two approaches (Dimovski et al, 1991). Another advantage is the rapid selection of unusual haplotypes that are associated with a milder expression of the disease; an example is a new genetic rearrangement for the hybrid haplotype $(3 / 19)$ found in a Turkish SS patient with mild disease and a high level of $\mathrm{Hb} \mathrm{F}$ (Oner et al, 1991). On the 
other hand, the method fajled to detect the rare ${ }_{B} S$ haplotype observed among Indian SS patients that is closely related to the common haplotype \#31 (Kulozik et al, 1986).

Acknowledgements. This study was supported by United States Public Health Service research grant HLB-41544.

\section{REFERENCES}

Abbes S, Fattoum S, Vidaud M, Goossens M, Rosa J (1991) Sickle cell anemia in the Tunisian population: Haplotyping and Hb F expression. Hemoglobin 15:1-9

Berg PE, Mittleman M, Elion J, Labie D, Schechter AN (1991) Increased protein binding to a -530 mutation of the human $B-g l o b i n$ gene associated with decreased $\beta$-globin synthesis. Am J Hematol 36:42-47

Bisse E, Wieland H (1988) High-performance liquid chromatographic separation of human haemoglobins - Simultaneous quantitation of foetal and glycated haemoglobins. J Chromatogr 434:95-110

Bouhassira EE, Lachman H, Krishnamoorthy R, Labie D, Nagel RL (1989) A gene conversion located $5^{\prime}$ to the $A_{Y}$ gene in linkage disequilibrium with the Bantu haplotype in sickle cell anemia. J Cl in Invest 83:2070-2073

Dimovski AJ, Oner C, Agarwal S, Gu Y-C, Kutlar F, Lanclos KD, Huisman THJ (1991) Certain mutations observed in the $5^{\prime}$ sequences of the $G_{\gamma^{-}}$and ${ }^{A}$ globin genes of ${ }_{B} S$ chromosomes are specific for chromosomes with major haplotypes. Acta Haematol 85:79-87

Fattoum $S$, Guemira F, Oner C, Oner R, Li H-W, Kutlar F, Huisman THJ (1991) $\beta$-Thalassemia, $H b$ S $-\beta$-thalassemia and sickle cell anemia among Tunisians. Hemoglobin 15:11-21

Gilman JG, Huisman THJ (1984) Two independent genetic factors in the $\beta$-globin gene cluster are associated with high $G_{Y}$ levels in the $H b F$ of SS patients. Blood 64:452-457

Gupta RB, Tiwary RS, Pande PL, Kutlar F, Oner C, Oner R, Huisman THJ (1991) Hemoglobinopathies among the Gond tribal groups of Central India; interaction of $\alpha$ - and $\beta$-thalassemia with $B$ chain variants. Hemoglobin 15:441-458

Hattori Y, Kutlar F, Kutlar A, McKie VC, Huisman THJ (1986) Haplotypes of ${ }_{\beta} S$ chromosomes among patients with sickle cell anemia from Georgia. Hemoglobin 10:623-642

Kulozik AE, Wainscoat JS, Serjeant GR, Kar BC, Al-Awamy B, Essan GJF, Falusi $A G$, Haque SK, Hilali AM, Kate AS, Ranasinghe WAEP, Weatherall DJ (1986) Geographical survey of ${ }_{B} S$ globin gene haplotypes: Evidence for an independent Asian origin of the sickle cell mutation. Am $J$ Hum Genet $39: 239-244$

Kutlar A, Hattori Y, Bakioglu I, Kutlar F, Kamel K, Huisman THJ (1985) Hematological observations on Arabian SS patients with a homozygosity or heterozygosity for a $B^{S}$ chromosome with haplotype \#31. Hemoglobin 9:545557

Kutlar A, Kutlar F, Gu L-G, Mayson SM, Huisman THJ (1990) Fetal hemoglobin in normal adults and B-thalassemia heterozygotes. Hum Genet 86 : 106-110 
Kutlar F, Kutlar A, Huisman THJ (1986) Separation of normal and abnormal hemoglobin chains by reversed phase high performance liquid chromatography. J Chromatogr $357: 147-153$

Lanclos KD, Oner C, Dimovski AJ, Gu Y-C, Huisman THJ (1991) Sequence variations in the $5^{\prime}$ flanking and IVS-II regions for the $G_{\gamma}$ - and $A_{\gamma-g l o b i n}$ genes of ${ }_{B} S$ chromosomes with five different haplotypes. Blood 77:2488-2496

Lapoumeroulie C, Dunda O, Trabuchet G, Mony-Lobe M, Labie D, Elion $J$, Krishnamoorthy $R$ (1989) A novel sickle gene of yet another origin in Africa: The Cameroon type. Blood 74:63a (Suppl 1)

Nagel RL (1984) The origin of the Hemoglobin $S$ gene: Clinical, genetic and anthropological consequences. Einstein Quart $\mathrm{J}$ Biol Med 2: 53-62

Nage1 RL, Ranney HM (1990) Genetic epidemiology of structural mutations of the $B-g l o b$ in gene. Semin Hematol $27: 342-359$

Ojwang $\mathrm{PJ}$, Ogada T, Beris P, Hattori $Y$, Lanclos KD, Kutlar A, Kutlar F, Huisman THJ (1987) Haplotypes and a globin gene analyses in sickle cell anaemia patients from Kenya. Br J Haematol 65:211-215

Oner C, Dimovski AJ, Altay C, Gurgey A, Gu YC, Huisman THJ, Lanclos KD (1991) Sequence variations in the $5^{\prime}$ hypersensitive site-2 of the locus control region of ${ }_{B} S$ chromosomes are associated with different levels of fetal globin in $\mathrm{Hb} \mathrm{S}$ homozygotes. Blood 78:813-819

Poncz M, Solowiejczyk D, Harpel B, Mory Y, Schwartz E, Surrey S (1982) Construction of human gene libraries from small amounts of peripheral blood: Analysis of $B-1$ ike globin genes. Hemoglobin 6:27-36

Ricco G, Mazza U, Turi RM, Pich PG, Camaschella C, Saglio G, Bernini LF (1976) Significance of a new type of human fetal hemoglobin carrying a replacement + isoleucine threonine at position 75(E19) of the $r$ chain. Hum Genet 32:305-313

Righetti PG, Gianazza E, Bianchi-Bosisio A, Cossu G (1986) Conventional isoelectric focusing and immobilized $\mathrm{pH}$ gradients for hemoglobin separation and identification. In Huisman THJ (ed): The Hemoglobinopathies. Methods in Hematology, Vol. 15. Churchill Livingstone, Edinburgh, pp 47-70

Schleider CTH, Mayson SM, Huisman THJ (1977) Further modification of the microchromatographic determination of Hemoglobin $A_{2}$. Hemoglobin $1: 503-504$

Schroeder WA, Huisman THJ (1980) The Chromatography of Hemoglobin. Clinical and Biochemical Analysis, Vol. 9. Marcel Dekker Inc, New York

Schroeder WA, Munger ES, Powars DR (1990) Sickle cell anaemia, genetic variations, and the slave trade to the United States. J African Hist 31: $163-180$

Shelton JB, Shelton JR, Schroeder WA (1984) High perfornance liquid chromatographic separation of globin chains on a large-pore $C_{4}$ column. J Liq Chromatogr $7: 1969-1977$

Wong SC, Stoming TA, Efremov GD, Huisman THJ (1989) High frequencies of a rearrangement ( + ATA; $-T$ ) at -530 to the $\beta$-globin gene in different populations indicate the absence of a correlation with a silent $B$-thalassemia determinant. Hemoglobin 13:1-5 
CHAPTER 3d

\title{
SEQUENCE VARIATIONS IN THE 5' hYPERSENSITIVE SITE-2 OF THE LOCUS CONTROL REGION OF $\beta$ S CHROMOSOMES ARE ASSOCIATED WITH DIFFERENT LEYELS OF FETAL GLOBIN IN HB S HOMOZYGOTES
}

\author{
C. Oner1, A.J. Dimovski1, C. Altay², A. Gurgey², \\ Y.C. Gul, T.H.J. Huisman1, and K.D. Lanclos 1 \\ 1 Department of Biochemistry and Molecular Biology \\ Medical College of Georgia, Augusta, GA 30912-2100, U.S.A. \\ 2 Children's Medical Center, Hacettepe University, Ankara, Turkey
}

(Adapted from: Blood, 79:813-819, 1992)

\begin{abstract}
We have compared the sequence of the $5^{\prime} H S-2$ of the LCR from an SS patient homozygous for haplotype \#19 and with low levels of Hb F, with the same sequence from an SS patient homozygous for haplotype \#3 and with high levels of Hb F. Several nt variations were present in the 5'HS-2 of the haplotype $\# 19$ individual. One is the $A+6$ at position -10905 that creates an Spl binding site $\operatorname{CCCCC}(A+6)$ CCCC. A second is the $T \rightarrow 6$ at position -10924 in a sequence that binds both erythroid and ubiquitous factors and exhibits high homology to the long terminal repeat of the Moloney leukemia viruses and Friend murine leukemia virus. Other differences were in the two AT rich stretches of DNA, and an $A \rightarrow T$ substitution at position -10390. Dot-blot analyses of amplified DNA from several SS patients showed that these variations are specific for ${ }_{\beta} S$ chromosomes with haplotype $\# 19$. We also examined the $5^{\prime} H S-2$ sequence from an SS patient who is homozygous for haplotype \#19 but has abnormally high levels of Hb F (>20\%). We observed a crossover that has placed sequences similar to the 5'HS-2 of haplotype \#3 in juxtaposition to the $5^{\prime}$ flanking regions of haplotype \#19. Thus, a ${ }_{\beta} S$ chromosome with haplotype \#19 but having a $5^{\prime} H S-2$ (LCR) characteristic for haplotype \#3 is associated with high $\gamma$ chain expression. We postulate that factors produced under condition of hematopoietic stress together with genetic determinants on the haplotype \#3-1ike LCR sequences allow for high level expression of B-globin genes.
\end{abstract}




\section{INTRODUCTION}

The human $\beta$-globin gene cluster is located on the short arm of chromosome 11 and is organized as $5^{\prime}-\varepsilon-G_{\gamma}-A_{\gamma-\psi \beta-\delta}-\beta-3^{\prime}$. This tandem sequence of genes is expressed in erythroid tissues in a developmentally specific manner $(1,2)$. The $\gamma-g$ lobin genes are coordinately switched off before birth, and by 6 months of age, the level of $H b F$ is only about $1 \%$ of the tota $1 \mathrm{Hb}$.

Several genetic variations in the B locus of chromosome 11 are known to be associated with increased levels of $H \mathrm{~b} F$ in the adult. Among these are the nondeletional forms of HPFH with specific mutations in the $5^{\prime}$ flanking regions of both $G_{\gamma}$ and $A_{Y}$ genes (reviewed in Ref. 3 ) and specific chromosomes found in conjunction with sickle cell anemia (4-7). Five major haplotypes are associated with sickle cell disease. These have been named the Benin, Bantu or CAR, Cameroon, Senegal, and the Saudi-Indian types, and have also been numbered as $\# 19, \# 20$, \#17, \#3, and \#31, respectively $(8,9)$; we have adopted the latter system of identification. The increased level of $\mathrm{Hb} F$ in SS adults is closely linked to the haplotype; those with types \#19, \#20, and \#17 generally have low levels of $H b F(1-10 \%)$, while haplotypes \#3 and \#31 are associated with higher levels of $H b F(15-30 \%)$ accompanied by a high $G_{\gamma}$ to $A_{Y}$ ratio. Sequence analyses of the $r 1.3 \mathrm{~kb}$ segments $5^{\prime}$ to the initiation CD and of the IVS-II of the ${ }^{G} r$ and $A_{r}$ globin genes of all five major haplotypes showed the presence of multiple sequence variations that are peculiar to each haplotype $(10,11)$. However, data from in vitro expression studies have indicated that the $G_{Y}$ and $A_{Y}$ promoters from $\beta^{S}$ chromosomes with the five different haplotypes have an identical (10w) effect on CAT expression (10).

The LCR was first described as a cluster of five DNase I HS sites located 6-18 kb upstream to the e-globin gene; one site is located $20 \mathrm{~kb}$ downstream from the B-globin gene $(12,13)$. It has been proposed that these HS sites, that confer both temporal and tissue specificity of gene expression, act in at least two ways. First is the organization of the entire B locus into an open domain (14-16) conferring erythroid specific expression of globin genes. It can also serve as a powerful enhancer of human globin expression when studied in transgenic mice and transfected erythroid cells, allowing for a high level of position independent, copy nunber dependent, erythroid specific expression (17-24). One segment of the LCR, called the 5'HS-2, alone can confer a high level expression in the range of $40 \%$ of the level obtained with the complete $\operatorname{LCR}(25,26)$. Detailed analyses of the 5 'HS-2 showed that it contains several conserved sequences that bind erythroid as well as ubiquitous nuclear transcriptional factors (27). Alterations in some of these sequences have dramatically changed the transcriptional enhancing activity of 5 'HS-2 in both transgenic mice and cultured erythroid cells $(17,27-30)$.

Here, we provide data about the sequences of the $5^{\prime} H S-2$ from $\beta^{S}$ chromosomes with haplotype \#19 (low Hb F expression) and haplotype \#3 (high $\mathrm{Hb} F$ expression), as well as of the $5^{\prime} \mathrm{HS}-2$ from a $\beta^{S}$ chromosome with a haplotype \#19 that exhibits high $\gamma$ chain expression $(>20 \%)$ and high $G_{\gamma}$ levels. 


\section{MATERIALS AND METHODS}

Blood samples from SS patients homozygous for haplotypes \#19 and \#3, were collected in EDTA and transported to the laboratory on ice. Hematological and $H b$ composition data were obtained with methodology described before (7). Informed consent was obtained.

DNA was isolated from the white cells by the method of Poncz et al (31). Amplification of the 739 bp Hind III/Bgl II fragment of the 5'HS-2 region of the LCR was with specific $5^{\prime}$ and $3^{\prime}$ oligonucleotide primers (Table $3 \mathrm{~d} / \mathrm{l}$ ). For asymmetric amplification, the reaction mixture contained $1 \mu \mathrm{g}$ of genomic DNA, $20 \mathrm{mM}$ MOPS, pH 7.8, $250 \mu \mathrm{M}$ each of dNTP's, $50 \mathrm{mM} \mathrm{NaCl}$, $3 \mathrm{mM} \mathrm{MgCl} 2,100$ pmoles of non-7imiting primer, 2 pmoles of limiting primer, and 2.5 units of Taq polymerase. PCR was carried out in a Perkin-Elmer Cetus Thermocycler. The condition of denaturation, annealing, and extension were $94^{\circ} \mathrm{C}$ for 1 minute, $55^{\circ} \mathrm{C}$ for 1.5 minutes, and $72^{\circ} \mathrm{C}$ for 3 minutes, respectively. The asymmetrically amplified 739 bp 5'HS-2 fragment was sequenced directly using the dideoxy termination procedure of Sanger et al (32).

TABLE 3d/1. Amplification Primers and Probes for Specific Variations

\begin{tabular}{|c|c|c|}
\hline Sequence & Positiona & Function \\
\hline $\begin{array}{l}5^{\prime} \text { TAAGCTTCAGTTITCCTTAGT } 3^{\prime} \\
5^{\prime} \text { TAGATCTGACCCCGTATGTGAGCAT } 3^{\prime}\end{array}$ & $\begin{array}{l}-11020 \text { to }-10998 \\
-10281 \text { to }-10306\end{array}$ & $\begin{array}{l}\text { Direct primer } \\
\text { Reverse primer }\end{array}$ \\
\hline $\begin{array}{l}5^{\prime} \text { CAGGCCCC T GTCGGGGTCA } 3^{\prime} \text { Norma } 1 \\
5^{\prime} \text { CAGGCCCC \& GTCGGGGTCA } 3^{\prime} \text { Mutant }\end{array}$ & -10932 to -10914 & $-10924(T 6)$ \\
\hline $\begin{array}{l}\text { 5' AGTGCCCC A cCCCCGCCT 3' Normal } \\
5^{\prime} \text { AGTGCCCC } 6 \text { cCCCCGCCT } 3^{\prime} \text { Mutant }\end{array}$ & -10913 to -10895 & $-10905(A+6)$ \\
\hline $\begin{array}{l}5^{\prime} \text { GGCATGAAA A CAGGAAAAG } 3^{\prime} \text { Norma } 1 \\
5^{\prime} \text { 6GCATGAAA T CAGGAAAG } 3^{\prime} \text { Mutant }\end{array}$ & -10400 to -10381 & $-10390(A+T)$ \\
\hline
\end{tabular}

a Position of the sequences located $5^{\prime}$ to the Cap site of the $\varepsilon-g$ lobin gene.

Aliquots of amplified DNA samples were blotted to nylon membranes and hybridized to specific $5^{\prime}$ end-labeled probes as described before $(33,34)$; the sequences and locations of the probes are listed in Table $3 d / 1$.

\section{RESULTS}

The locations and the types of changes observed for three different ${ }_{\beta} S$ chromosomes are listed in Fig. 3d/1, where these are compared to the reference sequence obtained from GenBank. DNA with haplotype \#19 has three differences, namely $T+6$ at position -10924, A-G at position -10905, and 
$A+T$ at position -10390 . Moreover, the repetitive region differs with eight AT at positions -10623 to -10602 , a T6 at positions -10592 and -10591, and seven AT at positions -10590 to -10570 . The only difference observed for the sequences in the DNA with haplotype \#3 is one less AT each of the two AT rich stretches. To confirm some of these results and to evaluate the specificity of the LCR $n t$ variations for $\beta S$ chromosomes with haplotype \#19, amplified DNA samples from 31 SS patients and five normal individuals with known haplotypes were evaluated by dot-blot analyses with specific probes. The results showed that the nt substitutions were specific for chromosomes with a defined haplotype.

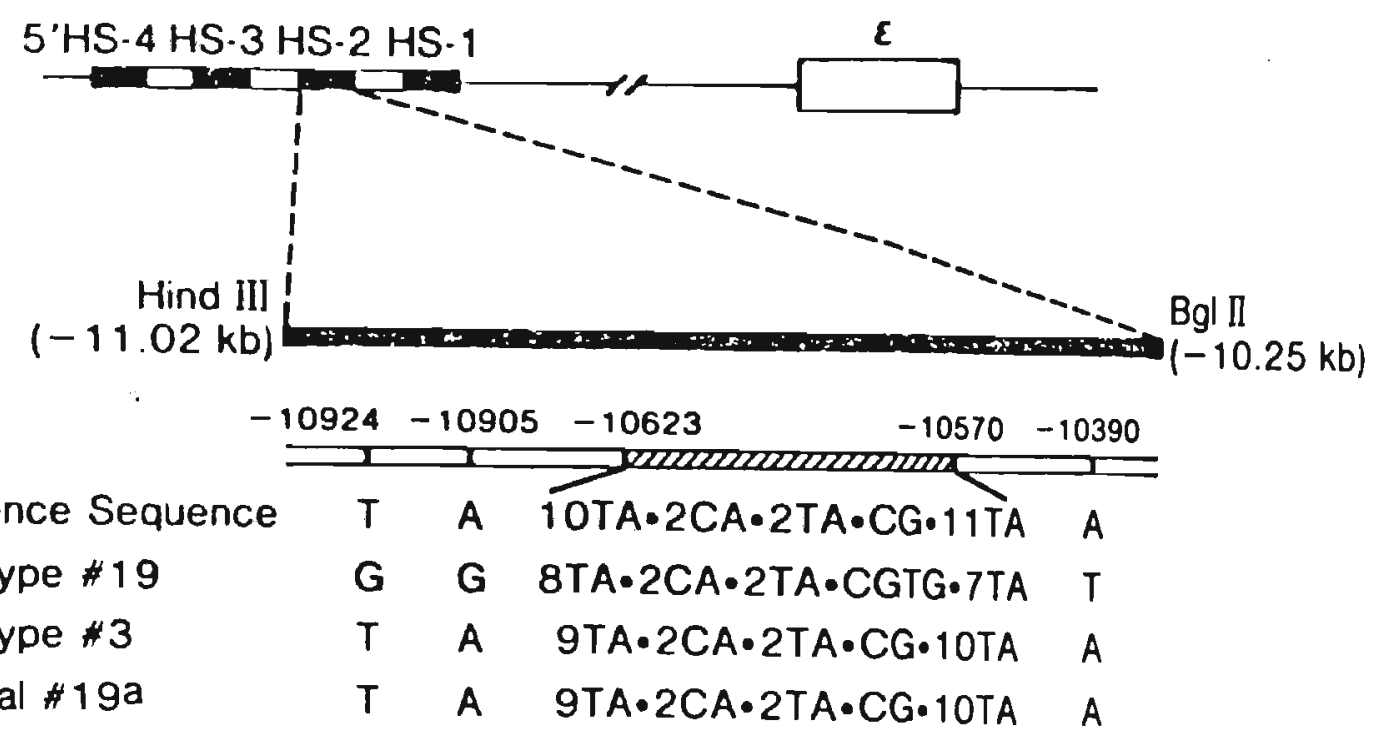

FI6. $3 d / 1$. Sequence differences in the $5^{\prime} H S-2$ regions of three $\beta^{S}$ chromosomes with different haplotypes. A description of the patient with the atypical haplotype "19a is given in the text. The reference sequence is from GenBank.

Previous observations describing specific sequence differences in the $5^{\prime}$ flanking region of the $G_{\gamma}$ - and $A_{\gamma}$-globin genes $(10,11)$ have indicated that, in a few instances, a $B S$ chromosome with haplotype $\# 19$ has undergone a recombinational event resulting in an atypical haplotype \#19 chromosome lacking the $C \rightarrow G$ at position $-3695^{\prime}$ to $G_{\gamma}$ that is characteristic of haplotype \#19. Of the more than $1000{ }_{\beta} S$ chromosomes tested from around the world, only 12 had this characteristic $(11,35)$. One of these persons is an 8-year-old Turkish SS patient with mild disease and high Hb $\mathrm{F}$ values; her parents are first cousins. Table $3 \mathrm{~d} / 2$ 1ists the hematological data. The high Hb $F$ value of over $20 \%$ and the high $G_{Y}$ value are indeed most uncharacteristic for SS patients homozygous for haplotype \#19 (7).

We have sequenced the $1.3 \mathrm{~kb} G$ promoter region of her $\beta^{S}$ chromosome and found the $A \rightarrow 6$ mutation at position $-3095^{\prime}$ to $G_{\gamma}$, the $6+T$ at position $-6575^{\prime}$ to $A_{\gamma}$, but no $C+6$ mutation at position $-369^{\prime} 5^{\prime}$ to $G_{\gamma ;}$ all three mutations are characteristic for haplotype \#19 $(10,39)$. An additional mutation ( $C \rightarrow 6$ at position -505) was also found in this individual. No 
effect on transient CAT expression was seen using $21.3 \mathrm{~kb} \mathrm{G}_{\gamma}$ promoter constructs containing the $-505 \quad C+6$ mutation (data not shown). Furthermore, this polymorphism was observed on 12 chromosomes characterized by various genetic backgrounds out of a pool of over 1000 patients. Sequence analysis of the amplified 5'HS-2 region from this patient showed that none of the mutations, characteristic for haplotype \#19, namely the $T \rightarrow 6$ at $-10924, A+6$ at -10905 , and $A H$ at -10390 were present. Moreover, the sequence in the repetitive purine/pyrimidine region between positions -10623 to -10570 was $9(T A) \cdot 2(C A) \cdot 2(T A) \cdot C G \bullet 10(T A)$, that is characteristic for haplotype \#3 (Fig. 3d/1).

TABLE 3d/2. Hematological Data for a Turkish SS Patient With Atypical Haplotype \#19a and for Her Parents

\begin{tabular}{|c|c|c|c|c|c|c|c|c|c|c|}
\hline ini & $\begin{array}{l}\text { Sex- } \\
\text { Age }\end{array}$ & $\begin{array}{c}\mathrm{Hb} \\
\mathrm{g} / \mathrm{dl}\end{array}$ & $\begin{array}{l}\text { PCV } \\
1 / 1\end{array}$ & $\begin{array}{c}\mathrm{RBC} \\
10^{12} / 1\end{array}$ & $\begin{array}{c}\text { MCV } \\
\text { fl }\end{array}$ & $\begin{array}{c}\mathrm{MCH} \\
\mathrm{pg}\end{array}$ & $\begin{array}{l}\mathrm{MCHC} \\
\mathrm{g} / \mathrm{dl}\end{array}$ & ${ }_{\mathrm{qa}}^{\mathrm{Hb}}$ & $\underset{\% \mathrm{a}}{\mathrm{Hb} F}$ & $\begin{array}{l}G y \\
q b\end{array}$ \\
\hline & & & & & & & & & & \\
\hline & $M=3$ & 17 & 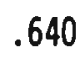 & 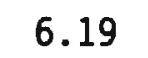 & 10 & 27 & & $c$ & & 43.3 \\
\hline .G. & $F-27$ & 14.5 & .560 & 5.38 & 104 & 27.0 & 25.9 & 3.0 & 0.7 & n.c \\
\hline
\end{tabular}

a Determined by cation exchange $\operatorname{HPLC}(36,37)$.

b Determined by reversed phase HPLC (38).

\section{DISCUSSION}

Variations in clinical severity observed in SS patients have been attributed to several factors (40). One is a variable expression of the $\gamma$-globin genes that is to some extent dependent upon the haplotype of the ${ }_{\beta} S$ chromosome. SS patients with either haplotype \#3 or \#31 have elevated levels of Hb F, while lower levels are found in SS patients with the other types. However, normal adults who do not have the ${ }_{\beta} S$ mutation but have either haplotype \#3 or \#19, exhibit levels of Hb F less than 1\%. The genetic determinants on chromosome 11 that are associated with $\boldsymbol{B}$ chain expression must, therefore, respond to factors that are the result of the hematopoietic stress of the sickle cell anemia. One region of chromosome 11 that is likely part of the complex regulation of $\gamma$ chain expression is the LCR. Here we have shown the existence of several variations in the $5^{\prime} H S-2$ of the LCR of $\beta^{S}$ chromosomes with haplotype \#19, that are not present on chromosomes with haplotype \#3. The location of these sequence variations and the relationship of these sequences to known protein binding sites within the $5^{\prime}$ HS-2 region are shown in Fig. $3 d / 2$.

The $T+6$ substitution at position -10924 downstream from the Hind III site is positioned in the sequence TTCTEGCCAGGCCCCT( $\rightarrow$ G)GTCGGGGTCAG. This sequence shows a high degree of homology with the enhancer sequence of the long terminal repeat of the Friend murine leukemia and Moloney leukemia viruses (41). Consensus sequences in this enhancer region bind several erythroid trans-acting factors (27). The second substitution $(A \rightarrow 6)$ at position -10905 is within the CACCC motif and results in the sequence CCCCA $(+6)$ CCCCC that is a perfect canonical Spl binding site (42). CACCC-1ike 
sequences bind at least two ubiquitous trans-acting factors; Sp1 and TEF-2 (CACCC box protein, or CBP) $(27,40)$. Analyses of the $\beta$-thal mutations at positions $-86,-87,-88$, and -92 affecting the CACCC box of the $\beta-g$ lobin gene indicate that this box is essential for an efficient expression of the $B$-globin gene. The well-known HPFH mutations (-198 $5^{\prime}$ to $A_{\gamma}$ and $-2025^{\prime}$ to $G_{Y}$ ) create an Spl binding site that results in enhanced Spl binding and over-expression of $\mathrm{Hb} F$ in transient CAT assays (43-45).

Location of:

Sequence

Varialions

Regulatory
Elements
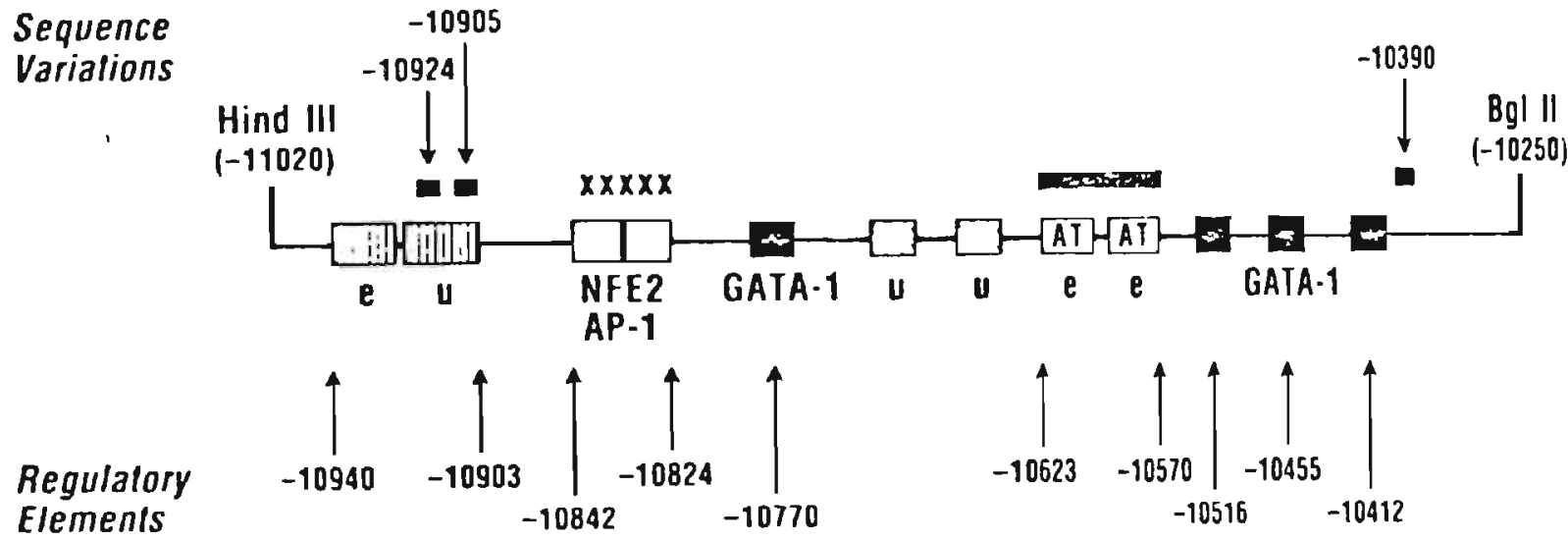

FI6. 3d/2. Comparison of sequence variations in the 5'HS-2 of the haplotype \#19 chromosome with known DNAse I footprinting sites. The diagram, that is not to scale, has been modified from that previously published (27). The area designated by $\mathbf{e}$ are footprints that appear only in erythroid extracts, $\mathbf{u}$ indicates ubiquitous footprints, and AT represents the presence of AT repeat sequences. The solid bars denote the regions of sequence variations in haplotype \#19. The $x x x x x$ shows the location of the region with maximal enhancer activity contained with tandem AP-1 binding sites (30). The numbers indicate positions relative to the Cap site of the gene.

The $A+T$ substitution at position -10390 occurs in the $3^{\prime}$ segment of the 5'HS-2 and creates a GATTC H4TF-1 site. This consensus sequence was first found in the promoter region of the human histone $\mathrm{H} 4$ gene (46). The H4TF-1 sites are required for expression of the $\mathrm{H}_{4}$ gene, and mutations in this site significantly reduce the level of transcription of the histone gene. The role of the A+T mutation in the $5^{\prime} \mathrm{HS}-2$ in erythroid gene expression, however, is not clear because removal of these sequences does not seem to affect the enhancer activity of the remaining segment $(27,28)$. The sequences of the purine/pyrimidine repetitive regions of the LCRs were found to be different and characteristic for ${ }_{B} S$ chromosomes with haplotypes $\# 19$ and \#3, and both differ from the sequence of the reference chromosome. This region of the $5^{1} \mathrm{HS}-2$ consists of two AT rich stretches separated by the CACATATACG motif (CACATATACGTG for haplotype "19). Similar AT repeat sequences have been found in the $5^{\prime}$ flanking region of the $\beta$-globin gene that bind the nuclear protein BP1 (47). BP1, a transacting factor found in both erythroid and non-erythroid cells, is believed to be involved in globin gene regulation as a silencer of transcription. More specifically, 
BP1 binds to a mutated sequence (+ATA/-T, located -530 bp $5^{*}$ to the Cap site of the $B$-globin gene). BPI binds nine times more strongly to this sequence than to a normal sequence and thus, BP1 may reduce globin gene expression by acting as a negative control element. The mutation (+ATA/-T) in the AT region of the $B$-globin gene produces an increased symmetry in this region that may result in enhanced binding of BP1 and decreased expression of the $\beta$-globin gene (48). A similarity was observed between the AT repeat sequence $5^{\prime}$ to the $B$-globin gene and the two AT rich sequences in the $5^{\prime} H S-2$ of the LCR from patients who have $B S$ chromosomes with haplotype \#19.

The possible importance of the LCR in the expression of Hb $F$ during conditions of hematopoietic stress is supported by the high $H \mathrm{~b} F$ levels found in two individuals. The patient (M.G.) with the atypical haplotype \#19 (Fig. 3d/2) exhibited mild disease with a $\mathrm{Hb} F$ level of more than $20 \%$ and high $G_{y}$ levels $(65 \%)$. These levels are more characteristic of homozygous SS patients with haplotypes \#3 or \#31. Our data showed that the $C \rightarrow G$ mutation at $-3695^{\prime}$ to $G_{Y}$, that is characteristic of haplotype \#19, is not present, while the $A+6^{2}$ mutation at position $-3095^{\prime}$ to $G_{\gamma}$ and the $G+T$ mutation at position $-6575^{\prime}$ to $A_{\gamma}$, both characteristic of haplotype \#19, were present. Sequence analysis of the 5'HS-2 of this patient showed that the purine/pyrimidine repetitive sequence was as observed for a $\beta S$ chromosome with haplotype \#3. Thus, the LCR region of this atypical \#19 chromosome might have arisen by a crossover between positions -309 and $-3695^{\prime}$ to the ${ }^{G} \gamma$ gene involving chromosomes with haplotypes \#3 and \#19 (Fig. 3d/3).
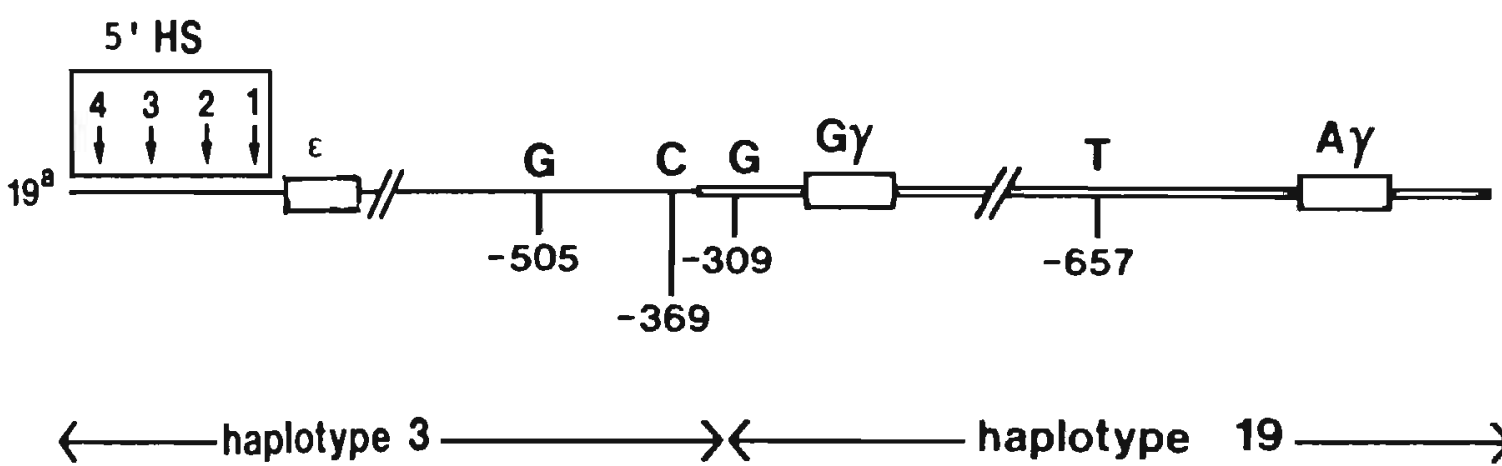

haplotype

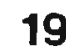

FI6. 3d/3. Hybrid haplotype for the $\beta S$ chromosome of patient M.G. with the atypical haplotype $19^{a}$.

The second patient is a 5-year-old Caucasian boy (D.C.), recently studied in our laboratory, who had a spontaneous mutation producing $\mathrm{Hb}$ Mizuho, which is an unstable $B$ chain variant with a Leu $\rightarrow$ Pro substitution at position 868 causing a severe hemolytic anemia. Our patient was quite different from the two cases published before $(49,50)$ because at the age of 5 years he had a $H b F$ level of 20 to $25 \%$ with a $G_{\gamma}$ level of $74 \%$, which is similar to levels in SS patients of comparable age but with ${ }_{B} S$ haplotypes \#3 or \#31, or the atypical haplotype \#19. Haplotype analysis showed the boy to have two virtually identical chromosomes, that differed only at the Bam HI polymorphism $3^{\prime}$ to the B gene (51). Analysis of the $5^{\prime} H S-2$ of his LCR identified a sequence in both chromosomes that was identical 
to that found in patients with haplotype $\# 3$ or with the atypical \#19 chromosome (unpublished data). The $\beta S$ chromosomes with haplotypes \#3 or \#31 and the $\beta X$ chromosome of patient D.C. all have a $C+T$ mutation at position $-1585^{\prime}$ to the ${ }^{G} \gamma$ gene. This mutation is known to be part of the genetic background that is associated with high $G_{\gamma}$ levels (5). However, the SS patient M.G. with an atypical haplotype \#19 had an elevated Hb F level in excess of $20 \%$ and $G_{Y}$ of $65 \%$ despite the absence of the $-158 \mathrm{C}+\mathrm{T}$ mutation $5^{\prime}$ to $G_{Y}$. This suggests that sequence variations in the LCR alone are sufficient for an elevated expression of the $\gamma$-globin genes and of the $G_{\gamma}$ gene, in particular.

Thus, some of the genetic determinants in both patients D.C. and M.G. that allow for increased $H b F$ expression are likely located within the LCR sequences of chromosome 11 . Perhaps the relatively unaltered sequence of the $5^{\prime} \mathrm{HS}-2$ of the chromosome with haplotype \#3, as compared to the reference sequence in the GenBank (see Fig. 3d/2), may represent a chromosomal structure that allows for optimal interaction of trans-acting factors produced under the influence of hematopoietic stress. Conversely, the sequence variations of the $5^{\prime}$ HS- 2 associated with haplotype \#19 and/or a combination of yet unknown sequence variations within the LCR, may result in a chromosomal structure that is not optimal for $\gamma$ gene expression during hematopoietic stress. The role presently played by these 5'HS-2 sequence variations in haplotype \#19 in fetal expression is unclear. Their location is outside of the tandem AP-1/NF-E2 sites, a region required for high levels of transcription. The sequence variations that we observed need not, however, fall within the tandem AP-1/NF-E2 sites to affect transcriptional activity. Indeed, sequences that are located downstream of the AP-1/NF-E2 sequences and upstream of the Xba I site are required for high levels of enhancement. However, recent studies have shown that both the chromatin structure and the position of the LCR relative to the $A_{\gamma}$ gene can affect developmental regulation of this gene in transgenic mice (53). Hence, the nt variations seen in 5'HS-2 of haplotype \#19, that result in two adjacent Spl binding sites as well as alterations in the AT repeat region, could significantiy affect the LCR structure and hematopoietic regulation of fetal globin gene expression.

Acknowledgments. This study was supported in part by USPHS Research Grant HLB-41544 (to T.H.J. Huisman), and by funds from the Prenatal Diagnosis Unit of the Turkish Scientific Research Foundation in Ankara, Turkey (to G. Altay and A. Gurgey).

\section{REFERENCES}

1. Karlsson S, Nienhuis A: Developmental regulation of human globin genes. Ann Rev Biochem 54:1071, 1985

2. Maniatis T, Fritsch EF, Lauer J, Lawn RM: Molecular genetics of human hemoglobin. Ann Rev Genet 14:145, 1981

3. Ottolenghi S, Mantovani R, Nicol is S, Ronchi A, Giglioni B: DNA sequences regulating human globin gene transcription in nondeletional hereditary persistence of fetal hemoglobin. Hemoglobin 13:523, 1989 
4. Labie D, Pagnier J, Lapoumeroulie F, Rouabhi F, Dunda-Belkhodja 0 , Chardin P, Beldjord C, Wajcman H, Fabry ME, Nagel RL: Common haplotype dependency of high $G_{\gamma-g l o b i n}$ gene expression and high $H b F$ levels in $B-$ thalassemia and sickle cell anemia patients. Proc Natl Acad Sci USA 82: 2111,1985

5. Gilman JG, Huisman THJ: Two independent genetic factors in the B-globin gene cluster are associated with high $G_{\gamma}$ levels in the $H b F$ of SS patients. Blood 64:452, 1984

6. Wainscoat JS, Thein SL, Higgs DR, Bell JI, Weatherall DJ, AlAwamy BH, Serjeant GR: A genetic marker for elevated levels of Haemog10bin $F$ in homozygous sickle cell disease? Br J Haematol 60:261, 1985

7. Hattori Y, Kutlar F, Kutlar A, McKie VC, Huisman THJ: Haplotypes of $\beta^{S}$ chromosomes among patients with sickle cell anemia from Georgia. Hemoglobin 10:623, 1986

8. Antonarakis SE, Boehm CD, Serjeant GR, Theisen CE, Dover GJ, Kazazian HH Jr: Origin of the ${ }_{\beta} S$ globin gene in Blacks; the contribution of recurrent mutation or gene conversion or both. Proc Natl Acad Sci USA $81: 853,1984$

9. Pagnier J, Mears JG, Dunda-Belkhodja 0, Schaefer-Rego KE, Beldjord C, Nagel RL, Labie D: Evidence for the multicentric origin of the sickle cell hemoglobin gene in Africa. Proc Nat] Acad Sci USA 81:1771, 1984

10. Lanclos KD, Oner C, Dimovski AJ, Gu Y-C, Huisman THJ: Sequence variations in the $5^{\prime}$ flanking and IVS-II regions of the $G_{Y-}$ and $A_{\gamma}$ globin genes of ${ }_{\beta} S$ chromosomes with five different haplotypes. Blood 77:2488, 1991

11. Dimovski AJ, Oner C, Agarwal S, Gu Y-C, Gu L-H, Kutlar F, Lanclos $K D$, Huisman THJ: Certain mutations observed in the $5^{\prime}$ sequences of the $\mathrm{G}_{\gamma-\text { and }} A_{\gamma-g l o b i n}$ genes of ${ }_{B} S$ chromosomes are specific for chromosomes with major haplotypes. Acta Haematol 85:79, 1991

12. Tuan D, Solomon $W, Q i l i a n g ~ L i$, London IM: The " $\beta-1 i k e-g l o b i n "$ gene domain in human erythroid cells. Proc Natl Acad Sci USA 82:6384, 1985

13. Forrester WC, Thompson C, Elder JT, Groudine M: A developmentally stable chromatin structure in the human B-globin gene cluster. Proc Natl Acad Sci USA 83:1359, 1986

14. Grosveld F, Blom van Assendelft G, Greaves DR, Kollias G: Positionindependent, high level expression of the human $\beta-g l$ lobin gene in transgenic mice. Cell 51:975, 1987

15. Jarman AP, Higgs DR: Nuclear scaffold attachment sites in the human globin gene complexes. EMBO J 7:3337, 1988

16. Smith S, Stillman B: Purification and characterization of chromatin assembly during DNA replication in vitro. Cell 58:15, 1989

17. Sorrentino B, Ney P, Bodine D, Nienhuis A: A 46 base pair enhancer sequence within the locus activation region is required for induced expression of the gamma-globin gene during erythroid differentiation. Nucleic Acids Res 18:2721, 1990

18. Boehringer RR, Ryan TM, Palmiter RD, Brinster RL, Townes TM: Human $\gamma$ - to $\beta$-globin gene switching in transgenic mice. Genes Develop $4: 380,1990$

19. Radice G, Constantini F: Tissue-specific DNase I hypersensitive sites in a foreign globin gene in transgenic mice. Nucleic Acids Res 14: 9765,1986 
20. Choi OR, Engle D: Developmental regulation of $\beta$-globin gene switching. Cell $55: 17,1988$

21. Tuan DYH, Solomon WB, London IM, Lee DP: An erythroid-specific, developmental-stage-dependent enhancer far upstream of the human " $\beta$-like globin" genes. Proc Natl Acad Sci USA 86:2554, 1989

22. Philipsen S, Talbot D, Fraser P, Grosveld F: The B-globin dominant control region: Hypersensitive site 2. EMBO J 9:2159, 1990

23. Enver T, Raich $N$, Ebens AJ, Papayannopoulou Th, Constantini $F$, Stamatoyannopoulos G: Developmental regulation of human fetal-to-adult globin gene switching in transgenic mice. Nature 344:309, 1990

24. Curtin PT, Liu D, Liu W, Chang JC, Kan YW: Human B-globin gene expression in transgenic mice is enhanced by a distant DNase I hypersensitive site. Proc NatT Acad Sci USA 86:7082, 1989

25. Fraser $P$, Hurst $J$, Coll is $P$, Grosveld F: DNase I hypersensitive sites 1, 2, and 3 of human $B-g l o b i n$ dominant control region direct position-independent expression. Nucleic Acids Res 18:3503, 1990

26. Ryan TM, Boehringer RR, Martin NC, Townes TM, Palmiter RD, Brinster RL: A single erythroid specific DNase I super-hypersensitive site activates high levels of human B-globin gene expression in transgenic mice. Genes Develop 3:314, 1989

27. Talbot D, Philipsen S, Fraser P, Grosveld F: Detailed analysis of the site 3 region of the human $B-g l o b i n$ dominant control region. EMBO J $9: 2169,1990$

28. Liu DP, Moi P, Liu W, Chang J, Kan YW, Curtin PT: An erythroid specific enhancer required a repeated $A P-1$ motif and other sequence elements for full activity in transgenic mice. Blood 76:68a (Suppl 1), 1990

29. Caterina JJ, Ryan TM, Pawlik KM, Palmiter RD, Brinster RL, Boehringer RR, Townes TM: Human B-globin locus control region: Analysis of the 5 ' DNAse I hypersensitive site HS 2 in transgenic mice. Proc Natl Acad Sci USA 88:1626, 1991

30. Ney PA, Sorrentino BP, McDonagh KT, Nienhuis AW: Tandem AP-1 binding sites within the human $B-g l o b i n$ dominant control region function as an inducible enhancer in erythroid cells. Genes Develop 4:993, 1990

31. Poncz M, Solowiejczyk D, Harpel B, Mory Y, Schwartz E, Surrey S: Construction of human gene libraries from small amounts of peripheral blood: Analysis of B-like globin genes. Hemoglobin 6:27, 1982

32. Sanger $F$, Nicklen $S$, Coulson AR: DNA sequencing with chain-terminating inhibitors. Proc Nat1 Acad Sci USA 74:5463, 1977

33. Saiki RK, Gelfand DH, Stoffel S, Scharf SJ, Higuchi R, Horn GT, Mullis KB, Erlich HA: Primer-directed enzymatic amplification of DNA with a thermostable DNA polymerase. Science 239:487, 1988

34. Gonzalez-Redondo JM, Stoming TA, Lanclos KD, GU YC, Kutlar A, Kutlar F, Nakatsuji T, Deng B, Han IS, McKie V.C, Huisman THJ: Clinical and genetic heterogeneity in Black patients with homozygous $B$-thalassemia from the Southeastern United States. Blood 72:1007, 1989

35. Oner $C$, Dimovski AJ, Olivieri NF, Schiliro G, Codrington JF, Fattoum S, Adekile AD, Oner R, Yuregir GT, Altay 6 , Gurgey A, Gupta RB, Jogessar VB, Kitundu MN, Loukopoulos D, Kutlar F, Gu L-H, Lanclos KD, Huisman THJ: $B$ S haplotypes in various world populations. Hum Genet $89: 99,1992$

36. Bisse $E$, Wieland $H$ : High-performance liquid chromatographic separation of human haemoglobins - Simultaneous quantitation of foetal and glycated haemoglobins. J Chromatogr 434:95, 1988 
37. Kutlar A, Kutlar F, Gu L-G, Mayson SM, Huisman THJ: Fetal hemoglobin in normal adults and B-thalassemia heterozygotes. Hum Genet 86:106, 1990

38. Shelton JB, Shelton JR, Schroeder WA: High performance liquid chromatographic separation of globin chains on a large-pore $C_{4}$ column. J Liq Chromatogr 7:1969, 1984

39. Month SR, Wood RW, Trifillis PT, Orchowski PJ, Sharon B, Ballas SK, Surrey S, Schwartz E: Analys is of the $5^{\prime}$ flanking regions of the gamma globin genes from major African haplotype backgrounds associated with sickle cell disease. $\mathrm{J}$ Clin Invest $85: 364,1990$

40. Nagel RL, Labie D: DNA haplotypes and the ${ }_{B} S$ gene, in Stamatoyannopoulos G, Nienhuis A (eds): Hemoglobin switching, Part B: Cellular and molecular mechanisms, New York, Liss, 1989, p 371

41. Bosze Z, Hans-Jurgen T, Charnay P: A transcriptional enhancer with specificity for erythroid cells is located in the long terminal repeat of the Friend murine leukemia virus. EMBO J 5:1615, 1986

42. Kadonaga JT, Carner KR, Masiarz FR, Tijan R: Isolation of CDNA encoding transcription factor SP1 and functional analysis of the DNA binding domain. Cell 51:1079, 1987.

43. Ronchi A, Nicolis S, Santoro C, Ottolenghi S: Increased Sp1 binding mediates erythroid-specific overexpression of a mutated (HPFH) $\gamma$-globin promoter. Nucleic Acids Res 17:10231, 1989

44. Fischer $K D$, Nowock $\mathrm{J}$ : The $T \rightarrow C$ substitution at -198 of the $A_{\boldsymbol{Y}}$ globin gene associated with the British form of HPFH generates overlapping recognition sites for two DNA-binding proteins. Nucleic Acids Res 18:5686, 1990

45. Sykes K, Kaufman R: A naturally occurring gamma globin gene mutation enhances Spl binding activity. Mol Cel1 Biol 10:95, 1990

46. Daily L, Hanly SM, Roeder RG, Heintz N: Distinct transcription factors bind specifically to two regions of the human histone $\mathrm{H} 4$ promoter. Proc Natl Acad Sci USA 83:7241, 1986

47. Berg PE, Williamis DM, Qian RL, Cohen RB, Cao S-X, Mittleman M, Schechter AN: A common protein binds to two silencers $5^{\prime}$ to the human B-globin gene. Nucleic Acids Res 17:8833, 1989

48. Berg PE, Mittleman M, Elion J, Labie D, Schechter AN: Increased protein binding to a -530 mutation of the human $B-g l o b i n$ gene associated with decreased $\beta$-globin synthesis. Am J Hematol 36:42, 1991

49. Ohba Y, Miyaji T, Matsuoka M, Sugiyama K, Suzuki T, Sugiura T: Hemoglobin Mizuho or beta 68 (E 12) leucine proline. A new unstable variant associated with severe hemolytic anemia. Hemoglobin 1:467, 1977

50. Labotka RJ, Vida LN, Honig GR: Hb Mizuho [B68(E12)Leu $\rightarrow$ Pro]. Second occurrence identified in a Caucasian child with hemolytic anemia and dense erythrocyte inclusions. Hemoglobin 14:129, 1990

51. Keeling MM, Baysal E, Gu Y-C, Cepreganova B, Wilson JB, Huisman THJ: Hb Mizuho or a $\beta_{2} 68$ (E12)LeutPro in a Caucasian boy with high levels of $\mathrm{Hb} \mathrm{F}$; identification by sequencing of amplified DNA. Hemoglobin 15:477, 1991

52. Talbot D, Grosveld F: The $5^{\prime}$ HS 2 of the globin locus control region enhances transcription through the interaction of a multicentric complex binding at two functionally distinct NF-E2 binding sites. EMBO J 10:1391, 1991 .

53. Dilion N, Grosveld F: Human $\gamma$-globin genes silenced independently of other genes on the B-globin locus. Nature 350:252, 1991 

CHAPTER 3e

\title{
HAPLOTYPE-SPECIFIC SEQUENCE VARIATIONS IN THE LOCUS CONTROL REGION (5' HYPERSENSITIVE SITES $2,3,4$ ) OF B $S$ CHROMOSOMES
}

\author{
A.D. Adekile, A.J. Dimovski, C. Oner, K.D. Lanclos, and T.H.J. Huisman \\ Department of Biochemistry and Molecular Biology \\ Medical College of Georgia, Augusta, GA 30912-2100, USA
}

[Adapted from: Hemoglobin, in press (1993)]

Analyses of the LCR $5^{\prime}$ HS 2, 3, and 4 core sequences have been carried out in $\beta^{5}$ chromosomes with the five major haplotypes [Senegal (\#3), Cameroon (\#17), Benin ( $\# 19)$, Central African Republic (CAR) ( $\# 20)$, and Indian (\#31)]. Haplotype-specific variations were found only in HS-2. These involved the two AT repeats located between positions -10623 and -10570 relative to the $\varepsilon$-globin gene Cap site, where different patterns were found in all haplotypes. Point mutations within the HS-2 were found only in chromosomes with haplotype $\# 19$ as previously reported (1). 
The LCR consists of a series of DNase I HS located between 6 and $18 \mathrm{~kb}$ $5^{\prime}$ to the $\varepsilon-g$ lobin gene promoter ( $5^{\prime} \mathrm{HS}-1, \mathrm{HS}-2, \mathrm{HS}-3$, and HS-4), and $20 \mathrm{~kb}$ $3^{\prime}$ to the B-globin gene (3' HS-1) (2). These sites define a region of the B-globin locus which activates the globin gene cluster in a tissuespecific, developmentally stable pattern and also serves as a powerful enhancer of gene expression. The $5^{\prime} \mathrm{HS}-2$ (at $\sim-10.9 \mathrm{~kb} 5^{\prime}$ of $\mathrm{E}$ ) accounts for 40-50\% of full LCR enhancer activity, while HS-3 (at $u-14.7 \mathrm{~kb}$ ) and HS-4 (at $2-18 \mathrm{~kb}$ ) contribute $230 \%$ each. There is no evidence that either $5^{\prime}$ HS-1 or 3' HS-1 individually contributes any significant enhancer activity; however, each HS may contribute in an additive or cooperative fashion, and no single site alone matches the potency of the whole $\operatorname{LCR}(3,4)$.

The factors modulating $\mathrm{Hb} F$ expression in ${ }_{\mathrm{B}} \mathrm{S}$ chromosomes are not fully understood. However, SS patients with haplotypes \#3 and \#31, who have a $C \rightarrow T$ substitution at $-158 \mathrm{G}_{\gamma}(X \mathrm{mn} I$ site), have elevated $H b F$ levels (5). Further understanding of the determinants of this persistent $H \mathrm{H} F$ expression will elucidate the mechanisms of the $\gamma->\beta$ switch in the $\beta$-globin gene cluster with implications for uTtimate clinical management of SS disease and $\beta$-thalassaemia ( $B$-thal). In a previous study from our laboratory Oner et al (1) demonstrated sequence variations within the $5^{\prime} \mathrm{HS}-2$ in $\beta^{S}$ haplotype \#19 (low Hb F) but not in haplotype \#3 (high Hb F) chromosomes, and suggested a possible role of the LCR sequences in the expression of $\mathrm{Hb} F$ during conditions of hematopoietic stress. However, no previous reports of HS-3 and HS-4 sequence analyses in ${ }^{S}$ chromosomes have appeared in the literature, and their role, if any, in $\mathrm{Hb} F$ expression in $S S$ patients is unknown.

We have extended these LCR sequence anaiyses to include ${ }_{\beta} S$ chromosomes with other haplotypes and in addition to $5^{\prime} \mathrm{HS}-2$, we have also studied the core enhancer sequences of the $5^{\prime}$ HS-3 and HS-4 to determine if haplotype specific variations exist in each of these sequences. Four chromosomes were studied for each of haplotypes \#3, \#19, and \#20, and two each with haplotypes \#17 and \#31.

DNA was isolated from leukocytes and haplotyping was done as previously reported (6). The following DNA fragments spanning the core sequences of the HS were amplified: The $739 \mathrm{bp}$ Hind III/Bgl II fragment of HS-2 (7); the $300 \mathrm{bp} \mathrm{Hph} \mathrm{I/Fnu} \mathrm{4HI} \mathrm{fragment} \mathrm{of} \mathrm{HS-3} \mathrm{(8),} \mathrm{and} \mathrm{the} 280 \mathrm{bp}$ Sst I/Ava I fragment of HS-4 (9). Sequence analysis was carried out with the chain termination method of Sanger et al (10). Table 3e/1 lists the amplification and sequencing primers and their positions. All nucleotide positions in the Table and the text are relative to the cap site of the e-globin gene.

No haplotype-specific sequence variations were found in the core sequences of $5^{\prime} \mathrm{HS}-3$ and $\mathrm{HS}-4$. However, an A->G substitution was found at position -18542, within the HS-4 sequence, on four chromosomes with haplotype \#3, and also on one chromosome with haplotype \#19. This mutation does not lie within a recognized protein binding site.

Within the $5^{\prime}$ HS-2, the two AT repeat sequences between positions -10623 and -10570 displayed haplotype-specific polymorphisms as follows: 
Haplotypes \#3 $[9($ AT) $n$ 10(AT) $]$, \#17 [8(AT) n 12(AT)], \#19 [8(AT) n 7(AT)], \#20 [8(AT) n $11($ AT) $)$, and \#31 [10(AT) n 12 (AT) $]$ ( $n$ = ACACATATACGT in ali haplotypes except type \#19 that has ACACATATACGTGT). Similar AT repeats have been found in the $5^{\prime}$ flanking region of the B-globin gene and bind the ubiquitous nuclear protein BP1. This protein is believed to be involved in globin gene regulation as a silencer of transcription (11). A homeodomain protein has also been described in $\mathrm{K} 562$ and baboon bone marrow nuclear extracts which bind specifically to the AT repeats in the LCR, the ${ }^{\gamma}$ promoter, and the $3^{\prime} A_{\gamma}$ enhancer (12).

TABLE 3e/1. Amplification and Sequencing Primers for HS-2, HS-3, and HS-4

Primer Position

HS-2 Amplification

\begin{tabular}{lll}
\hline Forward & $5^{\prime}$-TAAGCTTCAGTITITCCTTAGT-3' & -11020 to -10999 \\
Reverse & $5^{\prime}$-TAGATCTEACCCCGTATGTGAGCAT-3' & -10282 to -10305
\end{tabular}

HS-2 Sequencing

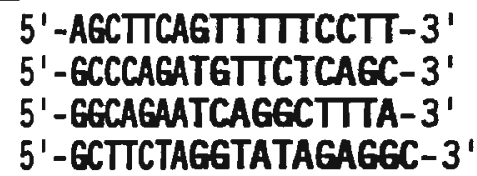

HS-3 Amplification

Forward 5'-CTTGTCTECTACCCCATCATA-3'

Reverse $5^{\prime}$-6TCCCTTCACCATCTTGTTTC- $3^{\prime}$

HS-3 Sequencing

5'-ATCATTCTGTGGATAA- 3'

5'-6GTGACTTTECGAGC- $3^{\prime}$

5'-GCTCAGATAGGTGGT-3'

HS-4 Amplification

Forward 5'-CGACCCATATAGACATT6-3'

Reverse 5'-GTGTAAAAAGGAGGATEC-3'

HS-4 Sequencing

5' -ACTTTGCCATCACTT- $3^{\prime}$

5'-CTITCTCTCTCCC-3'
-11018 to -11002
-10807 to -10791
-10488 to -10472
-10489 to -10506

-16111 to -16099

-14153 to -14173

-15087 to -15072

-14968 to -14954

-14854 to -14840

-18818 to -18801

-17768 to -17785

-18574 to -18560

-18438 to -18425

Point mutations within the 5' HS-2 [the A->6 at position -10905 which creates an SPI binding site, T->6 at position -10924 which is in a sequence that binds both erythroid and ubiquitous factors, and an A->T substitution at -10390 , as described previously (1)] were found only in haplotype \#19 chromosomes.

It appears, therefore, that among SS patients only the 5' HS-2 carries significant sequence variations. Interestingly, Oner et al (1) and Adekile et al (5) found SS patients in two families (one from Turkey and the other from Nigeria) with unusually high $G_{Y}(>70 \%)$ and $H b F(10$ to $20 \%)$ levels who had $G_{Y}$ promoter sequences specific for haplotype \#19. However, 5' HS-2 studies indicated that the sequence of this segment was similar to 
that found in $\beta^{S}$ haplotype $\# 3$ chromosomes, suggesting that the $\beta^{S}$ chromosomes in these persons were hybrids resulting from crossover events. These hybrids provide evidence of the modulatory role of the $5^{\prime}$ HS-2 sequences in $\mathrm{Hb} F$ expression, even in the absence of the $C->T$ substitution at -158 $\left({ }^{G} \gamma\right)$.

Acknowledgements. This study was supported by the United States Pub] ic Health Service research grant HLB-41544.

\section{REFERENCES}

1. Oner, C., Dimovski, A.J., Altay, C., Gurgey, A., Gu, Y-C., Huisman, T.H.J., and Lanclos, K.D., Blood, 79:813, 1991.

2. Orkin, S.H., Ce11, 63:665, 1990.

3. Ryan, T.M., Behringer, R.R., Martin, N.C., Townes, T.M., Palmiter, R.D., and Brinster, R.L., Genes Develop., 3:314, 1989.

4. Fraser, P., Hurst, J., Collis, P., and Grosveld, F., Nucleic Acids Res., 18:3503, 1990.

5. Adekile, A.D., Kitundu, M.N., Gu, L-H., Lanclos, K.D., Adeodu, 0.0., and Huisman, T.H.J., Ann. Hematol., 65:41, 1992.

6. Dimovski, A.J., Oner, C., Agarwal, S., Gu, Y-C., Gu, L-H., Kutlar, F., Lancios, K.D., and Huisman, T.H.J., Acta Haematol., 85:79, 1991.

7. Talbot, D., Philipsen, S., Fraser, P., and Grosveld, F., EMBO J., 9:2169, 1990 .

8. Philipsen, S., Talbot, D., Fraser, P., and Grosveld, F., EMBO J., 9:2159, 1990.

9. Pruzina, L., Hanscomb, 0., Whyatt, D., Grosveld, F., and Philipsen, S., Nucleic Acids Res., 19:1413, 1991.

10. Sanger, F., Nicklen, S., and Coulson, A.R., Proc. Natl. Acad. Sci. USA, 74:5463, 1990.

11. Berg, M.E., Mittelman, M., Elion, J., Labie, D., and Schechter, A.N., Am. J. Hematol., 36:42, 1991.

12. Lavelle, D., Ducksworth, J., Eves, E., Gomes, G., Keller, M., Heller, P., and DeSimone, J., Proc. Nat1. Acad. Sci. USA, 88:7318, 1991. 
4 B Black $\beta$-Thalassemia Homozygotes With Specific Sequence Variations in the 5' Hypersensitive Site-2 of the Locus Control Region Have High Levels of Fetal Hemoglobin

4b A $\beta^{\circ}$-Thalassemia Due to a 1605 bp Deletion of the $\beta$ Globin Gene Region

$4 c$ A Movel Deletion of $227 \mathrm{~Kb}$ Including the $\beta-$ Globin Gene and the LCR 3'HS-1 Regulatory Sequence: $B^{\circ}$-Thalasseaia or HPFH?

4d Polymorphic Pattern of the (AT) $X(T)_{Y}$ Motif at $-5305^{\prime}$ to the $\beta-61$ obin Gene in Over 40 Patients Homozygous for Various $\beta$-Thalassemia Mutations

4e The In Vivo Expression of the Globin Genes of the $B$ Cistron in $r, \delta-$, and $\delta \beta$-Thalassemia Heterozygotes 


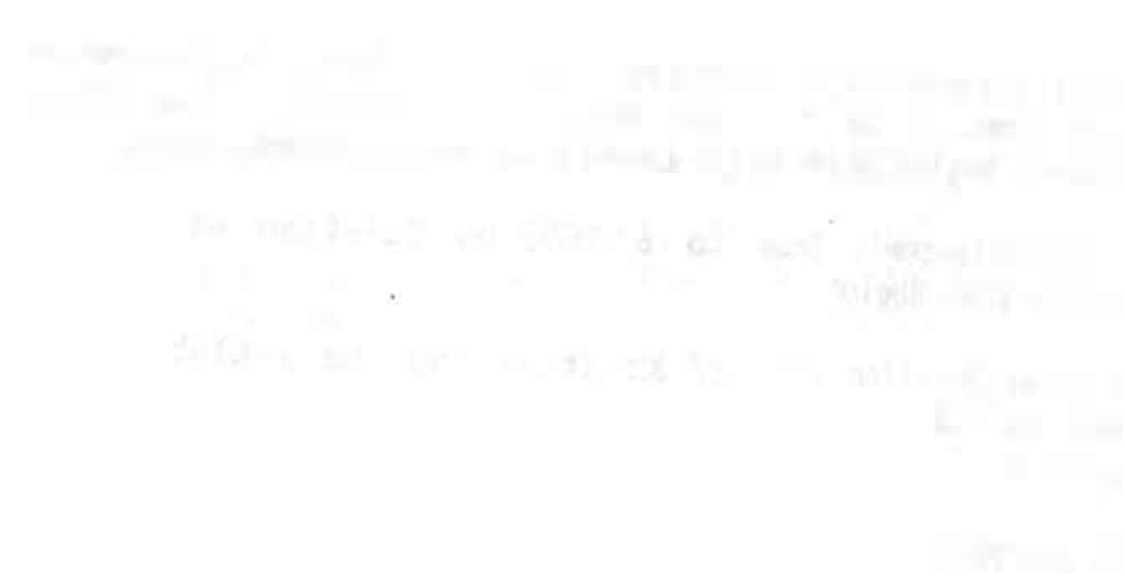




\title{
CHAPTER 4a
}

\section{BLACK B-THALASSEMIA HOMOZYGOTES HITH SPECIFIC SEQUENCE VARIATIONS}

IN THE 5' HYPERSENSITIVE SITE-2 OF THE LOCUS CONTROL REGION HAVE HIGH LEVELS OF FETAL HEMOGLOBIN

\author{
Ph. Beris', M.N. Kitundu2, E. Baysal2, C. Oner ${ }^{2}$, K.D. Lanclos 2 \\ A.J. Dimovski2, F. Kutlar2, and T.H.J. Huisman'2 \\ 1 Division d'Hematologie, Centre de Transfusion Sanguine \\ Hopital Cantonal Universitaire de Geneve, 1211 Geneve 4, Suisse \\ 2 Department of Biochemistry and Molecular Biology \\ Medical College of Georgia, Augusta, GA 30912-2100, U.S.A.
}

(Adapted from: Am. J. Hematol., 41:97-101, 1992)

\begin{abstract}
We have sequenced the 5 'HS-2 site of the LCR and the promoters of the two $\gamma$-globin genes located on chromosome 11 of a Black patient with mild $\beta$-thal major due to a homozygosity for the $C+T$ mutation at position -88 of the $B$ promoter and with a high $\mathrm{Hb} \mathrm{F}$ level. Sequence variations in the 5'HS-2 were the same as observed for the $\boldsymbol{B} S$ chromosome with haplotype \#3, while most of the $G_{\gamma}$ promoter and the $A_{Y}$ promoter had sequences similar to that of the $\beta^{S}$ chromosome with haplotype \#19. This atypical haplotype (\#19A) is apparently associated with an increased $Y$ chain production which is particularly evident during periods of severe hematopoietic stress. Additional studies on relatives of the proband and on 10 unrelated Black $B$-thal homozygotes with either the $C \rightarrow T$ mutation at -88 or the $\mathbf{A} \rightarrow \mathbf{G}$ mutation at -29 , confirm the possible importance of the sequence differences in the 5 'HS-2, and also suggest that at least two additional factors, namely a $C+T$ mutation at position -158 of the $G_{y}$ promoter and a relative deficiency in a chain synthesis, play a (perhaps less important) role in the increased $H b$ F synthesis in these patients.
\end{abstract}




\section{INTRODUCTION}

Recent studies of patients with SS with different $\beta^{S}$ haplotypes, characterized by specific nt variations in the sequences of the $5^{\prime} \mathrm{HS}-2$ of the LCR and of the promoters of the two $\gamma$-globin genes, have suggested that some of these variations might be responsible for differences in the in vivo expression of the $\gamma-g l o b i n$ genes $(1,2)$. The most important sequence variation may be the changes in the 5'HS-2 that affect binding of some erythroid and ubiquitous factors influencing $X$ chain synthesis. Another is the $C+F$ mutation at position -158 of the ${ }^{G}$ promoter; replacement of the $\mathbf{C}$ by a $\mathbf{T}$ is known to increase ${ }^{G_{\gamma}}$ chain production, particularly under anemic stress $(3,4)$. Thus, SS patients with a homozygosity for haplotype \#19 with specific variations in the $5^{\prime} \mathrm{HS}-2$ (details in Table 4a/2) and a $C$ at $-158\left(G_{Y}\right)$ have low levels of $H b F$, while SS patients with a homozygosity for haplotype \#3 and a $T$ at $-158\left(G_{Y}\right)$ have higher levels of $H b F$. Most interesting is the observation made in a Turkish SS patient with mild disease and a high $\boldsymbol{\gamma}$ chain production, who was homozygous for an atypical haplotype \#19 (termed \#19A) that has a 5'HS-2 characteristic for haplotype \#3. Perhaps factors produced under anemic stress associate with genetic determinants present on the $5^{\prime} \mathrm{HS}-2$ of haplotype $\# 3$, resulting in a greatly increased expression of the two $r$-globin genes.

If this assumption is correct, one can expect that patients with other anemic conditions such as a $B$-thal major, characterized by high $\mathrm{Hb} F$ levels, carry B-thal chromosomes with similar variations in their $5{ }^{\prime} H S-2$ and $G_{y}$ promoter sequences. Here we describe such a patient who appears to be homozygous for a $\boldsymbol{B}$-thal chromosome with the characteristics that have been observed for a $B S$ chromosome with haplotype \#19. Data from a study of this family which consists of a normal father and three children with a $B$-thal heterozygosity, indicate that an increased $H b F$ synthesis is already evident in the simple $\boldsymbol{B}$-thal heterozygotes, and is further augmented when a $\mathrm{C} \rightarrow \mathrm{T}$ mutation is present at position -158 of the ${ }^{G} \gamma$ promoter on the second chromosome.

\section{MATERIALS AND METHODS}

Blood samples from the five members of Family $B$ were collected in vacutainers with EDTA as anticoagulant, studied at the local institution, and shipped to Augusta, GA. Occasionally, DNA was isolated and sent overseas. Transportation was by fast overnight air mail service or by courier.

Hematological data were obtained with automated cell counters. The $\mathrm{Hb} F$ and $\mathrm{Hb} \mathrm{A}_{2}$ levels were quantified by cation exchange $\operatorname{HPLC}(5,6)$. The relative quantities of the $G_{\gamma}$ and $A_{Y}$ chains were determined by reversed phase HPLC $(7,8)$; Hb F was isolated from the blood samples of the three children by DEAE-cellulose chromatography (9) prior to the reversed phase HPLC analysis.

DNA was isolated from the samples with the method described by Poncz et al (10). a -Globin gene mapping followed procedures routinely used in our laboratory $(11,12)$. Three fragments of DNA of the $\beta$-globin gene cluster from mother (T.B.), namely the $5^{\prime} \mathrm{HS}-2$ region of the $L C R$ and the $G_{\gamma}$ and $A_{\gamma}$ 
promoters, were amplified and sequenced. Details of the methodology have been given in two recent publications $(1,2)$. The same $5^{\prime} H S-2$ and the $G_{\gamma}$ promoter segments were amplified from DNA samples of father (F.B.) and the three children (M.B., S.B. and Y.B.), and studied for possible mutations using hybridization with $32_{p}-1$ abeled oligonucleotide probes, as described elsewhere (2). The $\beta$-thal mutation in the mother and her three children was identified with a similar technique using primer sets that allowed amplification of the entire $\beta-g$ lobin gene $(13,14)$.

\section{RESULTS}

The Family. The proband (Mrs. T.B), a native of the Cote d'Ivoire, was diagnosed to have a $\beta$-thal major. She has been in remarkably good health with only mild clinical manifestations, no splenomegaly and no hemolysis (reticulocytes 1.2\%). She maintained a $\mathrm{Hb}$ level between 12 and $13 \mathrm{~g} /$ dl; recent hematological values, 1 isted in Table $4 a / 1$, indicate a marked microcytosis and hypochromia with a high $H b F$ level of nearly $80 \%$ ( $G_{\gamma}$ to $A_{\gamma}$ ratio at 58:42). She is married to a hematologically normal Swiss citizen. Their three children have a $\beta$-thal trait with mild microcytosis and hypochromia and elevated Hb F levels; the oldest child, M.B., has $3 \% \mathrm{Hb} F$ with a low $G_{\gamma}$ value of $25 \%$, and the two other children have $12.5-12.9 \% \mathrm{Hb} F$ with significantly higher $G_{Y}$ values of $40-44 \%$.

TABLE 4a/1. Hematological and Hb Composition Data (Family B)

\begin{tabular}{|c|c|c|c|c|c|c|c|c|c|c|c|c|}
\hline Case & $\begin{array}{l}\text { Sex- } \\
\text { Age }\end{array}$ & $\begin{array}{l}\text { Relation- } \\
\text { ship }\end{array}$ & $\begin{array}{l}H b \\
g / d l\end{array}$ & $\begin{array}{c}\mathrm{RBC} \\
1012 / 1\end{array}$ & $\begin{array}{l}P C V \\
1 / 1\end{array}$ & $\begin{array}{c}\mathrm{MCV} \\
\mathrm{fl}\end{array}$ & $\begin{array}{l}\mathrm{MCH} \\
\mathrm{pg}\end{array}$ & $\begin{array}{l}\mathrm{MCHC} \\
\mathrm{g} / \mathrm{dl}\end{array}$ & $\mathrm{A}_{\%}^{\mathrm{a}}$ & $\begin{array}{l}F^{a} \\
\%\end{array}$ & $\underset{\%}{G_{\gamma} b}$ & $\begin{array}{l}\text { \#a } \\
\text { Genes }\end{array}$ \\
\hline F.B. & $M-48$ & Father & 15.0 & 4.78 & .460 & 96.2 & 31.4 & 33 & 2.7 & 0.4 & 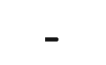 & - \\
\hline T.B. & $F-40$ & Mother & 12.5 & 6.07 & .379 & 62.5 & 20.5 & 33 & 3.6 & 79.1 & 58.4 & 4 \\
\hline M.B. & $F-20$ & Daughter & 12.3 & 5.59 & .396 & 71.0 & 22.0 & 31 & 4.7 & 3.0 & 24.9 & 4 \\
\hline S.B. & $F-18$ & Daughter & 12.6 & 5.04 & .394 & 78.0 & 25.0 & 32 & 4.4 & 12.5 & 44.0 & 4 \\
\hline Y.B. & $M-15$ & Son & 13.7 & 5.96 & .428 & 72.0 & 23.0 & 32 & 4.1 & 12.9 & 39.8 & 4 \\
\hline
\end{tabular}

a By cation exchange HPLC $(5,6)$.

b By reversed phase HPLC $(7,8)$.

Identification of the $\beta$-thal mutation was through dot-blot analysis of amplified DNA with 32p-labeled synthetic oligonucleotide probes; the mother was homozygous for the $\mathrm{C} \rightarrow \mathrm{T}$ mutation at -88 relative to the Cap site, while the three children were heterozygous for this mutation. This mild $\beta$-thal allele was first described in 1984 (15) and has since then been frequently observed among Black populations, particularly in the Southeastern United States $(13,16)$. No abnormality was observed in the father.

Sequence analyses of the amplified $G_{Y}$ and $A_{Y}$ promoters and the 5'HS-2 segment of the LCR of the chromosomes of the proband gave results that were nearly the same as those published $(1,2)$; therefore, details will not be presented except for a listing of differences that were observed. These data are compared in Table $4 a / 2$ with those for $B S$ chromosomes with haplotypes \#3, \#3A, and \#19, and with the atypical haplotype \#19A that was pres- 
ent in an adult Turkish SS patient with mild anemia and high levels of $\mathrm{Hb} F$ (2). The sequences of the 5'HS-2 segment differ at three positions and at the repetitive sequence between positions -10623 and -10570 (2), while those of the $G_{\boldsymbol{\gamma}}$ and $A_{\boldsymbol{\gamma}}$ promoters differ at five positions, as listed in Table 4a/2. The atypical haplotype \#19A resembles haplotype \#19 except at position $-369\left(G_{\gamma}\right)$ where a $C$ is present, while its $5^{\prime} H S-2$ sequence is the same as that on the $\beta S$ chromosome with haplotype \#3. The sequence data for the proband, T.B., show that she has a homozygosity for a $\beta$-thal chromosome with this atypical haplotype \#19A; the sequence of the $5^{\prime} H S-2$ is characteristic for haplotype \#3, position $-369\left(G_{\gamma}\right)$ is a $C$, while the nts in the other four positions are the same as present in a $\beta^{S}$ chromosome with haplotype \#19.

TABLE 4a/2. Differences in. Sequences of the $5^{\prime} H S-2$, the $G_{Y}$ Promoter, and the $A_{Y}$ Promoter for the Five Members of Family $B$

\begin{tabular}{|c|c|c|c|c|c|c|c|c|c|c|}
\hline \multirow{2}{*}{\multicolumn{2}{|c|}{ Positions }} & \multicolumn{4}{|c|}{ Haplotypesa } & \multirow{2}{*}{ F.B.b } & \multirow{2}{*}{ T.B.b } & \multirow{2}{*}{ M.B.b } & \multirow{2}{*}{\multicolumn{2}{|c|}{ S.B. b Y.B.b }} \\
\hline & & 3 & $3 A$ & 19 & $19 A$ & & & & & \\
\hline \multirow{4}{*}{5 'HS-2 } & & $T$ & $T$ & G & $T$ & TT & $\mathrm{TT}$ & TT & TT & $\mathrm{TT}$ \\
\hline & & A & $A$ & G & A & $A A$ & $A A$ & $A A$ & $A A$ & $A A$ \\
\hline & $\begin{array}{l}23 \text { through } \\
70\end{array}$ & (3) & & (19) & (3) & - & $(3)^{c}$ & - & - & - \\
\hline & & $A$ & A & $T$ & A & $A A$ & $A A$ & $A A$ & $A A$ & $A A$ \\
\hline \multirow{3}{*}{${ }^{G} \boldsymbol{\gamma}$ promoter } & -369 & C & c & G & c & $C C$ & $C C$ & $C C$ & $C C$ & $C C$ \\
\hline & -309 & $A$ & A & G & $\underline{\mathbf{G}}$ & $A A$ & 66 & $\underline{A G}$ & $A \underline{G}$ & A $\underline{G}$ \\
\hline & -158 & $\mathrm{~T}$ & C & c & $\underline{\bar{c}}$ & CT & $\underline{C C}$ & $C \underline{C}$ & T므 & $\underline{T C}$ \\
\hline \multirow[t]{2}{*}{${ }^{A} \boldsymbol{Y}$ promoter } & -657 & G & G & $\mathrm{T}$ & $I$ & - & $\underline{\Pi T}$ & - & - & - \\
\hline & -588 & G & G & A & $\underline{A}$ & - & $\underline{A A}$ & - & - & - \\
\hline
\end{tabular}

a See Refs. 1 and 2. The sequences at positions -10623 through -10570 for three haplotypes are 1 isted in Ref. 2.

b The data for T.B. were obtained by sequence analyses and confirmed by dot-blot analysis with specific probes; those for the other four members of Family B were by dot-blot analysis only.

c Number between parentheses identifies this sequence as being the same as that observed for a specific haplotype.

The data obtained for the husband, F.B., and the three children are more limited because only the nts at six specific locations (three in the $5^{\prime} H S-2$ and three in the $G_{\gamma}$ promoter) were identified through hybridization with specific probes. The two chromosomes of the husband resembled $\beta^{S}$ chromosomes with haplotype \#3 except for position $-158\left(G_{\gamma}\right)$ where a $T$ and a $C$ were present (designated as haplotypes \#3 and \#3A, respectively). The three children inherited one chromosome with haplotype \#19A from the mother, and from the father either one with haplotype \#3A (M.B.; $C$ at position -158, with $3 \% \mathrm{Hb} F$ and $25 \% \mathrm{G}_{\mathbf{Y}}$ ) or one with haplotype $\# 3$ (S.B. and T.B.; T at position -158 , with $212.5 \% \mathrm{Hb} F$ and $242 \% \mathrm{G}_{\gamma}$ ). 
The four members of Family $B$ who were tested had a normal complement of four $\alpha-g$ lobin genes $(\alpha \alpha / \alpha a)$.

\section{DISCUSSION}

There are several factors that are likely to be involved in the complex regulation of the expression of the $r$-globin genes. Among these are: a) variations in the sequence of the 5'HS-2 of the LCR that occur in locations known to be protein binding sites (2), b) a $C \rightarrow T$ mutation at position -158 relative to the Cap site of the $G_{\boldsymbol{\gamma}}$ globin gene $(3,4)$, and $\left.c\right)$ the number of active a-globin genes, because an a chain deficiency favors the formation of $\mathrm{Hb} A\left(\alpha_{2} B_{2}\right)$ over that of $H b F\left(\alpha_{2} \gamma_{2}\right)(17-19)$. Evidence is primarily based upon data from studies of SS patients (reviewed in Refs. 1 and 2); thus, SS patients with haplotypes \#3 or \#19A, both with identical 5'HS-2 sequences, have the same high levels of $H b F$, while SS patients with haplotype \#19 with specific variations in the 5'HS-2, have low Hb F levels. However, $\beta S$ chromosomes with haplotype \#3 have a $C+T$ mutation at position $-158\left(G_{\gamma}\right)$ that is known to be associated with increased $G_{\gamma}$ production, while those with haplotype \#19A do not. This suggests that sequence variations in the 5'HS-2 alone are sufficient to increase the expression of the rglobin genes and that the effect of the $C+T$ mutation at position $-1585^{\prime}$ to $G_{r}$ may be relatively minor.

Studies of other patients with greatly increased levels of $\mathrm{Hb} F$ have shown that some may have similar variations in the haplotype and $5^{\prime} \mathrm{HS}-2$ sequences. An example is a young patient with the unstable $\mathrm{Hb}$ Mizuho [a $\boldsymbol{\alpha}_{\boldsymbol{\beta}}$ 68(E12)Leu+Pro]; its presence causes a severe hemolytic anemia (20-22). Our patient differed from two previously reported patients in that he produced excessive amounts of $\mathrm{Hb} \mathrm{F}$ [about $35 \%$ at the age of 3 years, and $20-25 \%$ at the age of 5 years (20)] with high $G_{\gamma}$ values. Analysis of his 5 'HS-2 identified a sequence for both chromosomes that was the same as that of ${ }_{B} S$ chromosomes with haplotypes \#3 or \#19A $(2,20)$.

The patient described here has an unusually mild $\boldsymbol{B}$-thal major with high levels of $\mathrm{Hb} F$. She has never been transfused (except during pregnancy) and is the mother of three children. There is no evidence of hemolysis or splenomegaly. The sequences of her 5'HS-2 and the promoters of the $G_{\gamma-}$ and $A_{\gamma-g l o b i n}$ genes are identical to those of the $\beta$ with the haplotype \#19A characteristics (Table 4a/2). This $B$-thal chromosome with the atypical haplotype \#19A does not carry the $C \rightarrow T$ mutation at position $-1585^{\prime}$ to $G_{\gamma}$; therefore, other sequence variations similar to those on the $B S$ chromosome with the same haplotype seem to be responsible for the increased $\gamma$ chain production under hematopoietic stress. The $\beta A$ chromosomes of her normal husband have haplotype \#3 characteristics, although there is a $C+T$ heterogeneity at position $-158\left({ }^{G} \gamma\right)$ (Table $\left.4 a / 2\right)$. The effect of this $C+T$ variation is evident in the offspring; two children with a $\beta$-thal chromosome with haplotype \#19A and a $B A$ chromosome with haplotype \#3 $\left[T\right.$ at $\left.-158\left(G_{\gamma}\right)\right]$ have high $H b F$ values of $12.5-13.0 \%$ with $G_{Y}$ values of $40-44 \%$, while one child with a similar combination but with $C$ at position $-158 G_{\gamma}$ on the chromosome with haplotype \#3A, has only $3 \% \mathrm{Hb} F$ with a significantly lower ${ }^{G} \gamma$ value of $25 \%$. 
Do other patients with a similar type of B-thal major have comparable haplotypes? A few years ago we presented data for several Black patients who were mildly affected and had high levels of $H b F$. We restudied 10 patients, three with a homozygosity for the $C+T$ mutation at -88 of the $\beta-$ globin gene promoter (the same mutation is present in the proband, T.B.) and seven with a homozygosity for the more common A+6 mutation at -29 of the $\beta-g l o b i n$ gene promoter $(13,23)$. The analyses were limited to an evaluation of the variations in sequence at positions -10924 ( $T$ or 6$),-10905$ (A or $\mathbf{G}$ ), -10390 (A or T) of the $5^{\prime} \mathrm{HS}-2$, and at positions -369 (C or G), -309 ( $A$ or 6 ), and -158 ( $T$ or $C)$ of the ${ }^{G} \boldsymbol{\gamma}$ promoter, through hybridization of amplified segments of DNA with the appropriate $32 p$-labeled synthetic oligonucleotide probes. All 10 patients lacked the variations in the 5'HS-2 characteristic for haplotype $\# 19$, and thus were considered to have haplotypes \#3, \#3A, or \#19A. The additional data, namely the variations in the $\mathrm{G}_{\gamma}$ promoter and the levels of $\mathrm{Hb} \mathrm{F}$ and $\mathrm{G}_{\boldsymbol{\gamma}}$, are listed in Table $4 \mathrm{a} / 3$. Five subjects, two with a homozygosity for the $-88(\mathrm{C}-\mathrm{T})$ mutation and three with that for the $-29(\mathbf{A}+\mathbf{G})$ mutation, had only $\mathbf{C}$ at -369 , only $\mathbf{A}$ at -309 , and only $T$ at -158 , and thus can be considered homozygous for haplotype \#3. Their $\mathrm{Hb} F$ values varied from $62-72 \%$ with high $G_{\gamma}$ values $(69-78 \%)$. Patient T.M.F. had similar variations except for a homozyosity for a $\mathbf{C}$ at -158 (haplotype \#3A); his Hb F level was distinctly lower (57\%) as was his $G_{y}$ value $(34 \%)$. Patients L.G. and S. Ja., both with the $A+6$ mutation at -29 , were homozygous for haplotype \#3 except that one chromosome had a $T$ (haplotype \#3) and the other a $C$ at position -158 (haplotype \#3A). Their $G_{y}$ values were high (65-67\%) with high $H b F$ values; the lower level (44\%) in L.G. may be attributed to a relatively mild a chain deficiency (-a/aa). The siblings, Jo.S. and J.S., with a $-29(\mathbf{A + G})$ homozygosity, had one chromosome with haplotype \#3 and the other with haplotype \#19A (as in the proband T.B.). Moreover, both had an $\alpha$-thal-2 heterozygosity (-a/aa). Their $G_{\gamma}$ values remained high $(58-63 \%)$ as expected but the $\mathrm{Hb} F$ values varied considerably.

In conclusion, the data obtained in the study of Family $B$ and the information collected for the 10 additional Black patients with a homozygosity for one of two common B-thal alleles support the concept that specific variations in the sequences of the $5^{\prime} \mathrm{HS}-2$ segment of the LCR, together with a $C+T$ mutation at position -158 in the $G_{Y}$ promoter and a possible variation in the number of $a-g l o b i n g e n e s$ are at least in part responsible for the variations observed in the level of Hb F. Apparently this is not only the case for SS patients with specific haplotypes (2) but also for patients with B-thal major or with a specific unstable $\mathrm{Hb}$ causing a severe hemolytic anemia, or perhaps even for normal persons without any known hemoglobinopathy. Persons with sequences of the 5'HS-2 segment of the LCR of haplotype \#3 appear to be able to activate both $\boldsymbol{\gamma}$-globin genes during periods of severe anemic stress.

Acknowledgements. This study was supported by grant 32-31342.91 (to Ph.B.) from the Swiss National Foundation for Scientific Research, and by the United States Public Health Services research grant HLB-41544 (to T.H.J.H.). 
TABLE 4a/3. Sequence Variations in the $G_{Y}$ Promoter Regions of chromosomes From 11 Black Subjects With a B-Thal Homozygositya

\begin{tabular}{|c|c|c|c|c|c|c|c|c|}
\hline \multirow[t]{2}{*}{ Case } & \multirow{2}{*}{$\begin{array}{l}\text { Sex- } \\
\text { Age }\end{array}$} & \multirow{2}{*}{$\begin{array}{l}\text { B-Thal } \\
\text { Mutation }\end{array}$} & \multirow[t]{2}{*}{$\begin{array}{l}F \\
q\end{array}$} & \multirow{2}{*}{$\underset{q}{G}$} & \multicolumn{3}{|c|}{$\begin{array}{l}\text { Variations in } \\
G_{\gamma} \text { Promoter }\end{array}$} & \multirow{2}{*}{$\begin{array}{l}\| \alpha \\
\text { Genes }\end{array}$} \\
\hline & & & & & -369 & -309 & -158 & \\
\hline $\begin{array}{l}\text { Haplotype } \\
\text { Haplotype } \\
\text { Haplotype } \\
\text { Haplotype }\end{array}$ & $\begin{array}{l}\# 3 \\
\# 3 A \\
\# 19 \\
\# 19 A\end{array}$ & & & & $\begin{array}{l}C \\
C \\
G \\
C\end{array}$ & $\begin{array}{l}A \\
A \\
G \\
\underline{6}\end{array}$ & $\begin{array}{l}T \\
C \\
C \\
C\end{array}$ & \\
\hline T.B. & $F-40$ & -88 (C T) & 79.1 & 58.2 & $\mathrm{CC}$ & 66 & $\underline{C C}$ & 4 \\
\hline $\begin{array}{l}\text { H.G. } \\
\text { C.W. } \\
\text { I.M. } \\
\text { D.B. } \\
\text { F.S. }\end{array}$ & $\begin{array}{l}M-80 \\
F-24 \\
F-44 \\
F-8 \\
F-27\end{array}$ & $\begin{array}{l}-88 \text { (C T) } \\
-88 \text { (C T) } \\
-29 \text { (A G) } \\
-29 \text { (A G) } \\
-29 \text { (A G) }\end{array}$ & $\begin{array}{l}65.2 \\
71.7 \\
68.0 \\
67.1 \\
61.9\end{array}$ & $\begin{array}{l}69.3 \\
72.0 \\
70.0 \\
73.5 \\
77.8\end{array}$ & $\begin{array}{l}C C \\
C C \\
C C \\
C C \\
C C\end{array}$ & $\begin{array}{l}A A \\
A A \\
A A \\
A A \\
A A\end{array}$ & $\begin{array}{l}\text { TT } \\
\text { TT } \\
\text { TT } \\
\text { TT } \\
\text { TT }\end{array}$ & $\begin{array}{l}4 \\
4 \\
4 \\
4 \\
4\end{array}$ \\
\hline T.M.F. & $M-23$ & -88 (C T) & 56.6 & 34.2 & $\mathrm{CC}$ & $A A$ & $\mathrm{CC}$ & 4 \\
\hline $\begin{array}{l}\text { L.G. } \\
\text { S.Ja. }\end{array}$ & $\begin{array}{l}F-26 \\
F-13\end{array}$ & $\begin{array}{ll}-29 & \left(\begin{array}{ll}A & 6\end{array}\right) \\
-29 & \left(\begin{array}{ll}A & 6\end{array}\right)\end{array}$ & $\begin{array}{l}43.8 \\
73.9\end{array}$ & $\begin{array}{l}66.9 \\
64.7\end{array}$ & $\begin{array}{l}C C \\
C C\end{array}$ & $\begin{array}{l}A A \\
A A\end{array}$ & $\begin{array}{l}\text { TC } \\
\text { TC }\end{array}$ & $\begin{array}{l}3 \\
4\end{array}$ \\
\hline $\begin{array}{l}\text { Jo.S. } \\
\text { J.S. }\end{array}$ & $\begin{array}{l}F-27 \\
M-23\end{array}$ & $\begin{array}{l}-29 \text { ( A } 6 \text { G) } \\
-29 \text { (A G) }\end{array}$ & $\begin{array}{l}49.0 \\
36.3^{b}\end{array}$ & $\begin{array}{l}58.4 \\
63.2^{b}\end{array}$ & $\begin{array}{l}C C \\
C C\end{array}$ & $\frac{A G}{A \underline{G}}$ & $\begin{array}{l}T C \underline{C} \\
T \underline{C}\end{array}$ & $\begin{array}{l}3 \\
3\end{array}$ \\
\hline
\end{tabular}

a Data are from Ref. 13 except for the variations in the $G_{\gamma}$ promoter.

b Data are from a recently collected blood sample; the values reported in the original study (13) were $11.9 \%$ and $60.3 \%$.

\section{REFERENCES}

1. Lanclos KD, Oner C, Dimovski AJ, Gu Y-C, Huisman THJ: Sequence variations in the $5^{\prime}$ flanking and IVS-II regions of the $G_{\gamma}$ and $A_{\gamma-g l o b i n}$ genes of ${ }_{\beta} S$ chromosomes with five different haplotypes. Blood $77: 2488$, 1991.

2. Oner C, Dimorski AJ, Altay 6 , Gurgey A, Gu Y-C, Huisman THJ, Lanclos $\mathrm{KD}$ : Sequence variations in the $5^{\prime}$ hypersensitive site-2 of the locus control region of $\beta^{S}$ chromosomes are associated with different levels of fetal globin in Hb S homozygotes. Blood 79:813, 1992.

3. Gilman JG, Huisman THJ: DNA sequence variations associated with elevated fetal $G_{Y}$ globin production. Blood 66:783, 1985.

4. Hattori Y, Kutlar F, Kutlar A, Mckie VC, Huisman THJ: Haplotypes of ${ }_{\beta} S$ chromosomes among patients with sickle cell anemia from Georgia. Hemoglobin 10:623, 1986.

5. Bisse E, Wieland H: High-performance liquid chromatographic separation of human haemoglobins - Simultaneous quantitation of foetal and glycated haemoglobins. J Chromatogr 434:95, 1988.

6. Kutlar A, Kutlar F, Gu L-G, Mayson SM, Huisman THJ: Fetal hemoglobin in normal adults and $\beta$-thalassemia heterozygotes. Hum Genet 85:106, 1990. 
7. Shelton JB, Shelton JR, Schroeder WA: High performance liquid chromatographic separation of globin chains on a large-pore $C_{4}$ column. J Liq Chromatogr 7:1969, 1984.

8. Kutlar F, Kutlar A, Huisman THJ: Separation of normal and abnormal hemoglobin chains by reversed-phase high-performance liquid chromatography. J Chromatogr 357:147, 1986.

9. Schroeder WA, Huisman THJ: The Chromatography of Hemoglobin. Clinical and Biochemical Analysis, Vol. 9, New York, Marcel Dekker, Inc., 1980.

10. Poncz M, Solowiejczyk D, Harpe1 B, Mory $Y$, Schwartz E, Surrey S: Construction of human gene libraries from small amounts of peripheral blood: Analysis of B-like globin genes. Hemoglobin 6:27, 1982.

11. Felice AE, Cleek MP, Marino EM, MCKie K, McKie VC, Chang BK, Huisman THJ: Different $\boldsymbol{\zeta}$ globin gene deletions among Black Americans. Hum Genet 73:221, 1986.

12. Gu YC, Landman H, Huisman THJ: Two different quadruplicated a globin gene arrangements. $\mathrm{Br} J$ Haematol 66:245, 1987.

13. Gonzalez-Redondo JM, Stoming TA, Lanclos KD, Gu YC, Kutlar A, Kutlar F, Nakatsuji T, Deng B, Han IS, McKie VC, Huisman THJ: Clinical and genetic heterogeneity in Black patients with homozygous $\beta$-thalassemia from the Southeastern United States. Blood 72:1007, 1988.

14. Gonzalez-Redondo JM, Stoming TA, Kutlar A, Kutlar F, Lanclos KD, Howard EF, Fei YJ, Aksoy M, Altay C, Gurgey A, Basak AN, Efremor GD, Petkov $G$, Huisman THJ: $A \quad C \rightarrow T$ substitution at nt -101 in a conserved DNA sequence of the promoter region of the $\beta-g l o b i n g e n$ is associated with "silent" $\beta$-thalassemia. Blood 73:1705, 1989.

15. Orkin SH, Antonarakis SE, Kazazian HH Jr: Base substitution at position -88 in a B-thalassemic globin gene. J Biol Chem 259:8679, 1984.

16. Gonzalez-Redondo JM, Kutlar A, Kutlar F, McKie VC, McKie KM, Baysal E, Huisman THJ: Molecular characterization of $H b S(C) \beta$-thalassemia in American Blacks. Am J Hematol 38:9, 1991.

17. Abraham EC, Huisman THJ: Differences in affinity of variant chains for a chains: A possible explanation for the variation in the percentages of B chain variants in heterozygotes. Hemoglobin 1:861, 1977.

18. Qiu CC, Abraham EC: Evidence for posttranslational control of fetal hemoglobin synthesis. Am J Hematol 29:58, 1988.

19. Oner C, Gurgey A, Altay 6, Kutlar F, Huisman THJ: Variation in the level of fetal hemoglobin in $(\delta \beta)^{\circ}$-thalassemia heterozygotes with different numbers of a-globin genes. Am J Hematol 34:230, 1990.

20. Keeling MM, Bertolone SJ, Baysal E, Gu Y-C, Cepreganova B, Wilson JB, Huisman THJ: Hb Mizuho or a2B268(E12)Leu+Pro in a Caucasian boy with high levels of $\mathrm{Hb} F$; identification by sequencing of amplified DNA. Hemoglobin 15:477, 1991.

21. Ohba Y, Miyaji T, Matsuoka M, Sugiyama K, Susuki T, Sugiura T: Hemoglobin Mizuho or beta 68 (E 12 ) leucinesproline. A new unstable variant associated with severe hemolytic anemia. Hemoglobin 1:467, 1977.

22. Labotka RJ, Vida LN, Honig GR: Hb Mizuho [B68(E12)Leu+Pro]. Second occurrence identified in a Caucasian child with hemolytic anemia and dense erythrocyte inclusions. Hemoglobin 14:129, 1990.

23. Antonarakis SE, Orkin SH, Cheng T-C, Scott AF, Sexton JP, Trusko SP, Charache S, Kazazian HH Jr: B-Thalassemia in American Blacks: Novel mutations in the "TATA" box and an acceptor splice site. Proc Natl Acad Sci USA 81:1154, 1984. 
CHAPTER 4b

\section{A $\beta^{\circ}$-THALASSEMIA DUE TO A 1605 BP DELETION OF THE 5' -G-GLOBIN GENE REgION}

A.J. Dimovski1, D.6. Efremov2, L. Jankovic ${ }^{1}$, D. Plaseskal,

D. Juricic ${ }^{3}$, and G.D. Efremov 1

1 Macedonian Academy of Sciences and Arts

Research Center for New Technologies, 91000 Skopje, Macedonia

2 Department of Hematology, Faculty of Medicine, 91000 Skopje, Macedonia

3 Department of Clinical Chemistry

Hospital Dr. 0. Novosel, 41000 Zagreb, Croatia

[Adapted from: Br. J. Haematol., in press (1993)]

\section{SUIMARY}

We studied a heterozygous $\boldsymbol{B}^{\circ}$-thal patient from Croatia with an unusually high $\mathrm{Hb} \mathrm{A}_{2}$ level of $7.6 \%$ and an elevated $\mathrm{Hb} F$ level of $5.8 \%$. The same condition was found in his father ( $\mathrm{Hb} \mathrm{A}_{2} 8.2 \% ; \mathrm{Hb} F \mathrm{8.5 \%}$ ). Gene mapping and direct sequencing analyses revealed a new deletion of 1605 bp in the $5^{\prime} \beta-g$ lobin gene region between positions $-984 / 5$ and $+620 / 1$. This deletion has not been observed among more than $500 \beta$-thal chromosomes from the Balkan countries studied in our laboratory. 


\section{INTRODUCTION}

The $\beta$-thalassemias are a heterogeneous group of disorders characterized by decreased ( $\beta^{+}$-thal) or absent ( $\beta^{\circ}$-thal) $\beta$-globin chain synthesis. More than 130 point mutations or deletions/insertions of a few nts affecting the B-mRNA transcription, processing, or transiation have been detected. On the other hand, the deletions associated with $B^{\circ}$-thal are relatively rare. Ten deletions, ranging from $44 \mathrm{bp}$ up to $12.6 \mathrm{~kb}$ have been described so far (for references see the $\beta$ - and $\delta$-Thalassemia Repository, 1992). Specific sequence variations in the LCR $5^{\prime} \mathrm{HS}-2$ and the ${ }^{\gamma} \boldsymbol{r g l o b i n}$ gene promoter might account for the modest elevation of $\mathrm{Hb} F$ in the two heterozygotes studied.

In this paper we present a new deletion in the $5^{\prime} \beta$-globin gene region detected in a heterozygous $\beta$-thal subject from Croatia. The patient exhibited microcytosis and hypochromia with unusually high $\mathrm{Hb}_{2} \mathrm{~A}_{2}(7.6 \%)$ and elevated $H b F(5.8 \%)$ levels. Gene mapping analyses and direct sequencing of amplified DNA showed that the deletion is 1605 bp long with the $5^{\prime}$ end at position -984 or -985 , and the $3^{\prime}$ end at position +620 or +621 , both relative to the Cap site of the $B$-globin gene. Nt sequence analysis of the deletion breakpoint suggests that it is a result of the non-homologous recombination involving simple breakage, followed by an end-to-end joining event. The unusual B-thal heterozygote phenotype observed in our patient complies with previous findings that the loss of the 5 ' $B$-globin gene region is associated with unusually high $\mathrm{Hb}_{2} \mathrm{~A}_{2}$ levels.

\section{MATERIALS AND METHODS}

Blood Samples. Blood samples from the propositus and his father were collected in vacutainers with EDTA as anticoagulant. Informed consent was obtained.

Hematological and Hb Studies. Hematological data were obtained on freshly collected blood samples using an automated cell counter. Hb $A_{2}$ and $H b F$ were quantitated by microcolumn chromatography (Efremov et al, 1974) and alkali denaturation (Betke et al, 1959), respectively. The $G_{\gamma}$ values were evaluated by PAGE (Aiter et al, 1980). In vitro chain synthesis analys is used methodology described el sewhere (Huisman and Jonxis, 1977).

Gene Mapping Analyses. DNA was isolated from the white blood cells using the method of Poncz et al (1982). Southern blot analysis followed procedures routinely used in our laboratory (Efremov et al, 1986). The probe used for Brglobin gene mapping was a Bam HI/Eco RI fragment of the B-IVS-II, labelled to high activity by the random primed labelling method (Feinberg and Vogelstein, 1983). The a-globin gene mapping was done using the methodology described by Felice et al $(1984 ; 1986)$.

PCR and Direct Nt Analyses. A segment of the B-globin gene was amplified by the PCR procedure (Saiki et a1, 1988) using the primers D1 $5^{\prime}-\pi T$ CCTICTGATAACTAGAAATAG-3' (direct) at positions - 1485 to -1462 , and R1 $5^{\prime}$ - CACTITAACCCATAAATATGTATA- $3^{\prime}$ (reverse) at positions +1036 to +1013 , both 
relative to the Cap site of the $\beta$-globin gene. The 2900 bp amplification product from the deleted chromosome was eluted from the agarose gel using the GeneClean Kit (Bio 101; Bio-Rad Laboratories, Richmond, CA, USA). Direct sequence analysis was performed by the dideoxy chain termination method (Sanger et al, 1977), using T7 DNA polymerase (Sequenase; USB, Cleveland, OH, USA), ${ }^{55}$ S-dATP (Amersham International, Amersham, Bucks, England), and internal primer D2 5'-CCTCACCTGAGGAGTTAAT- 3 ' at positions -1140 to -1122 relative to the Cap site.

Analysis of the LCR 5' HS-2 (850 bp Hind III/Bgl II fragment) and of the $G_{Y}$ promoter ( 450 bp 5 ' flanking region) was by sequencing of PCR-amplified DNA using methodology described elsewhere (Lanclos et al, 1991; Oner et al, 1992).

\section{RESULTS}

Hematology. The propositus was a 24-year-01d male from Croatia who had mild hypochromia and microcytos is ( $\mathrm{Hb} 14.7 \mathrm{~g} / \mathrm{dl}$; PCV $0.461 / 1$; MCV $72 \mathrm{fl}$; MCH $22 \mathrm{pg}$ ) with unusually high $\mathrm{Hb} \mathrm{A}_{2}(7.6 \%)$ and elevated $\mathrm{Hb} \mathrm{F}$ (5.8\%) levels. The in vitro chain synthesis revealed an imbalanced synthesis with an $\alpha / \beta$ ratio of $\overline{1.9}$ and $\alpha /$ non-a ratio of 1.6 . The same condition was found in his father (Hb $12.7 \mathrm{~g} / \mathrm{dl}$; PCV $0.401 / 1$; MCV $69 \mathrm{fl}$; MCH $22 \mathrm{pg}$; Hb $\mathrm{A}_{2} 8.3 \%$; $H b F$ 8.5\%; $\alpha / \beta$ and $\alpha /$ non-a ratios of 2.1 and 1.8 , respectively).

Gene Mapping Analyses. Genomic DNA of the propositus and a normal control was digested with various restriction enzymes and hybridized to a Bam HI/Eco RI fragment of the B-IVS-II. The results obtained with the enzymes whose restriction sites flank the $\boldsymbol{B}$-globin gene (e.g. Bgl II, Eco RI, Pst I, Hind III) constantly showed additional bands of $1.6 \mathrm{~kb}$ smaller than the normal fragments. Larger abnormal fragments were obtained with Nco I and Ava II restriction enzymes, suggesting the loss of the Nco I site at position +52 , and of the Ava II site in exon 2 at position +293 . The polymorphic Ava II site in the $\beta$-IVS-II region at position +507 was either absent or deleted. The sizes of the fragments obtained with these two enzymes were smaller by $1.6 \mathrm{~kb}$ of the sum of the adjacent fragments. The Hinc II digestion revealed an abnormal fragment of $4.4 \mathrm{~kb}$, thus localizing the $5^{\prime}$ breakpoint of the deletion within a region of 630 bp between two Hinc II sites at positions -1441 and -813 . No abnormal fragment was observed after Rsa I digestion. The gene mapping analyses data are summarized in Fig. 4b/1. They show a deletion of $1.6 \mathrm{~kb}$ in the $5^{\prime}$ region of the B-globin gene, with the $5^{\prime}$ breakpoint between two Hinc II sites at positions -1441 and -813, and the $3^{\prime}$ breakpoint in the IVS-II region between the Ava II site at position +293 and the Rsa I site at position +823 .

a-Globin gene mapping showed an aa/aa genotype for both the father and the propositus.

PCR and Sequencing Analyses. In order to characterize the exact breakpoint of the deletion, oligonucleotide primers D1 and R1, localized outside the deletion endpoints, were synthesized. PCR amplification showed a fragment of 900 bp from the deleted chromosome, while the normal fragment of 
2521 bp was almost invisible. The specificity of these fragments was confirmed by Southern blot hybridization with the B-IVS-II probe (data not shown). The 2900 bp fragment was eluted from agarose gel and directly sequenced using an internal primer (D2). The sequence obtained was compared to the published sequence of the $\beta-g$ lobin gene region. It was possible to localize the breakpoint within $\pm 1 \mathrm{nt}$ because of the junctional homology of the guanidine nt common to both ends. The deletion is 1605 bp long with the $5^{\prime}$ end at position -985 or -984 and the $3^{\prime}$ end at position +620 or +621 , both relative to the Cap site of the $\beta$-globin gene.

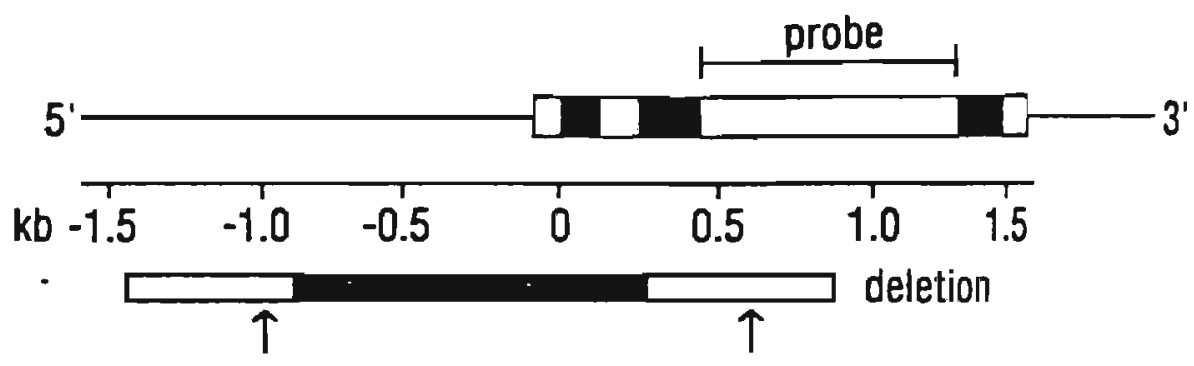

Abnomal

Fragment

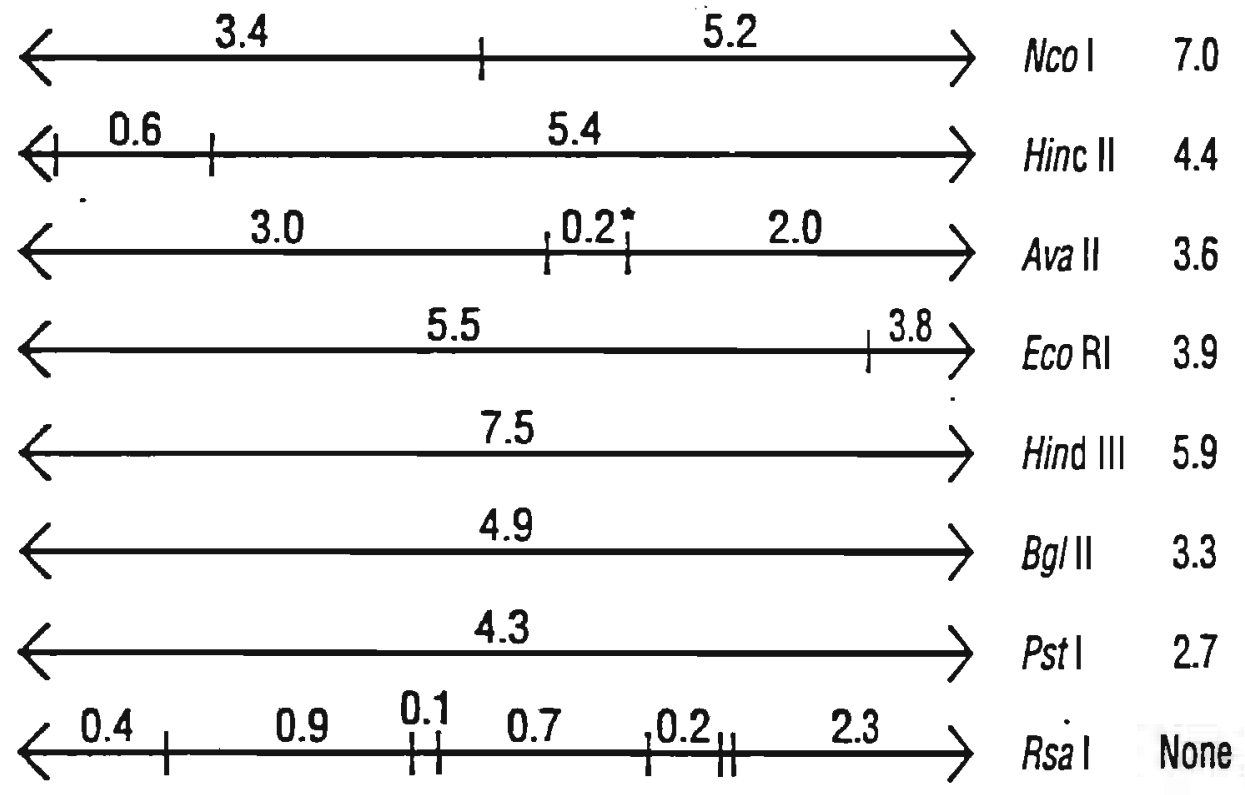

*Polymorphic site

FI6. 4b/1. A restriction map of the $\beta$-globin gene with a summary of the results from the Southern blot analyses. Locations of the $5^{\prime}$ and $3^{\prime}$ breakpoints of the deletion as determined by gene mapping ( ) and by direct sequencing $(+)$ are presented. The order of the restriction sites was determined from the GenBank file (HUMHBB).

The sequence analyses of the LCR $5^{\prime} H S-2$ and the $G_{Y}$ promoter region were performed on the DNA samples from both the propositus and the father. The LCR 5' HS-2 sequences were identical to the reference sequences except for the AT repeat motif located at -10570 to -10623 relative to the Cap site of the B-globin gene. The father was homozygous for the (AT) 9 (AT) 10 motif, while the propositus was heterozygous for the (AT) $9 n$ (AT) 10 and (AT) $8 \mathrm{n}$ (AT) 10 motifs (where $n$ stands for ACACATATACGT). The only observed 
observed variation in the $G_{\gamma}$ promoter region, a $C+T$ substitution at position -158 which creates an Xmn I restriction enzyme site, was found in a homozygous state in both the propositus and the father. These results suggest that the chromosome with the Croatian deletion has the (AT) $9 n$ (AT) 10 motif in the $5^{\prime}$ HS-2 and a T at -158 in the $G_{y}$ promoter, which has been previously observed on $\beta^{S}$ chromosomes with haplotype \#3 (Oner et al, 1992), and on $\beta$-thal chromosomes with haplotype IV (unpublished data).

No sequence homology was found when the junction fragment was aligned with normal $5^{\prime}$ and $3^{\prime}$ sequences (Fig. 4b/2). Direct or inverted repeats cormon to both ends were not found. However, the analys is of the $5^{\prime}$ breakpoint revealed the presence of AATCA inverted and GAAT direct repeats, one of each being removed by the deletion. A perfect 9 bp palindrome sequence [AAGGTGGAA] is formed at the breakpoint.

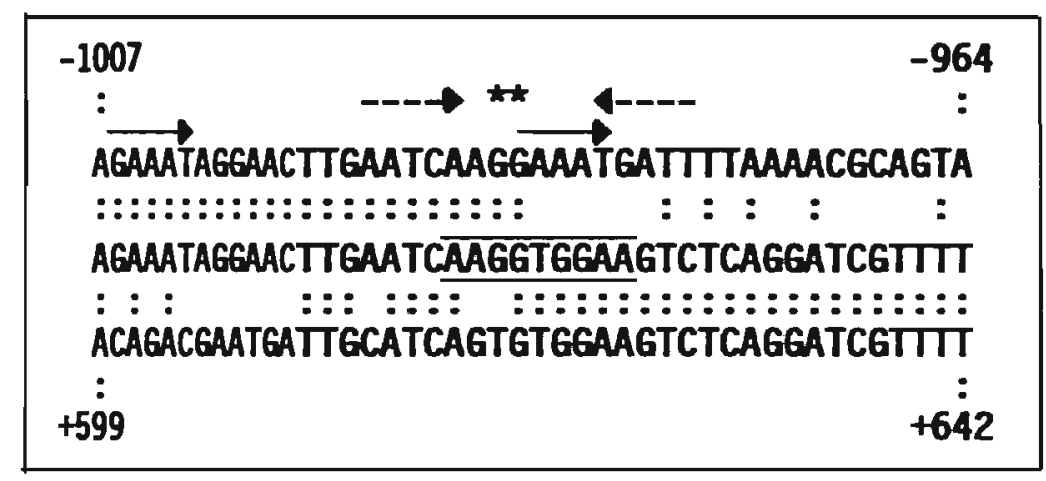

FI6. 4b/2. Sequence analysis of the breakpoints of the deletion. B : Nt sequence of the junction fragment (middle) aligned with the normal $5^{\prime}$ (upper) and normal 3' (lower) B-globin gene sequences. Sequence homology is indicated as vertical dashes. Two possible 5 ' breakpoints are indicated by asterisks $(*)$. The direct $(\longrightarrow)$ and reversed $(--\rightarrow)$ repeats spanning the $5^{\prime}$ breakpoint are also shown. The perfect 9 bp palindrome formed by the deletion is presented in the open rectangle. All positions are relative to the Cap site of the $B-g l o b i n$ gene.

\section{DISCUSSION}

In this paper we present a new deletion in the $5^{\prime} B-g l o b i n$ gene region detected in a heterozygous $\boldsymbol{\beta}$-thal patient from Croatia. The propositus was a 24-year-old male who presented with mild hypochromia and microcytos is with unusually high levels of $\mathrm{Hb} \mathrm{A}_{2}(7.6 \%)$ and elevated $\mathrm{Hb} F(5.8 \%)$. The same condition was observed in his father. Gene mapping and direct sequence analysis of PCR amplified DNA revealed the presence of a $1605 \mathrm{bp}$ deletion that removes 985 bp of the $5^{\prime}$ flanking region, the $5^{\prime}$ untranslated region, exon 1, exon 2, and 125 bp of the IVS-II of the $\beta-g l o b i n$ gene. This deletion has not been observed among more than $500 \mathrm{~B}$-thal chromosomes from the Balkan countries studied in our laboratory.

Ten other deletions, ranging from $44 \mathrm{bp}$ up to $12.6 \mathrm{~kb}$, and removing a part of or the whole B-globin gene have been described so far (for references see the $\beta$ - and $\delta$-Thalassemia Repository, 1992). In eight of them 
various portions of the $5^{\prime}$ B-globin gene region are removed (Fig. 4b/3), e.g. Czechoslovakian 4237 bp (Popovitch et al, 1986); Black 1393 bp (Padanilam et al, 1984; Anand et a 1, 1988; Gonzalez-Redondo et al, 1989; The in et al, 1989); Turkish 290 bp (Gonzalez-Redondo et al, 1989; Diaz-Chico et a 1, 1987; Aulehla-Scholz et a1, 1989; The in et al, 1992); Black 532 bp (Waye et al, 1991); Dutch 12.6 bp (Gilman et al, 1984; Gilman, 1987); Thai 3.4 bp (Sanguansermsri et al, 1980; Lynch et al, 1991), Australian $12 \mathrm{~kb}$ (Motum et al, 1992), and Asian Indian $10.3 \mathrm{~kb}$ deletion(s) (Craig et al, 1992). $B$-Thal heterozygotes for each of these eight deletions also exhibited significantly higher $\mathrm{Hb} \mathrm{A}_{2}$ levels than $B$-thal heterozygotes with point mutations or deletions in other parts of the gene. It has been shown that in these patients the increase in $\delta$-globin gene expression is disproportional, with higher output from the gene in cis to the deletion (Codrington et a 1, 1990). Sequence comparison of these deletions shows that the region between -125 to +78 relative to the Cap site of the $\beta$-globin gene is missing in each of them (Waye et al, 1991). This region, which includes the CAC, CAT, and TATA boxes of the B-globin gene promoter, is also removed in the Croatian 1605 bp deletion.

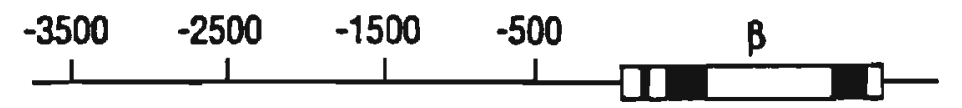

$\mathrm{HbF} \quad \mathrm{HbA2}$

$(\%) \quad(\%)$

\begin{tabular}{|c|c|c|c|}
\hline Croatian & 1605 & $5.8-8.8$ & $7.6-8.6$ \\
\hline Turkish & $\underline{290}$ & $2.7-8.8$ & $7.1-8.1$ \\
\hline Black & 532 & 0.2 & 8.6 \\
\hline Black & 1393 & $1.8-7.4$ & $72-8.4$ \\
\hline Czech & & $3.5-5.7$ & $8.1-9.0$ \\
\hline Dutch & 12622 & $5.1-14.4$ & $5.3-7.6$ \\
\hline Thai & 3405 & 4.5 & 6.7 \\
\hline Australian. & 12023 & $25-72$ & $6.4-8.1$ \\
\hline Asian Indian & & $3.2-4.7$ & 7.1 \\
\hline
\end{tabular}

FI6. 4b/3. A map of the various deletions affecting the $5^{\prime} B$-globin gene region in $B^{\circ}$-thal. The levels of $H b A_{2}$ and $H b F$ observed in $B$-thal heterozygotes for each of them is al so shown.

Several hypotheses have been proposed to explain the increased expression of the $\delta$-globin gene observed in these deletions such as altered chromatin structure (Anand et a 1, 1986; Thein et a1, 1989; Haye et al, 1991), $3^{\prime}$ B-globin gene enhancer juxtaposition (Diaz-Chico et al, 1987) or altered competition of the remaining $\delta$ - and $\gamma$-globin gene promoters for limited transacting factors (Thein et al, 1989). Recent studies have suggested 
the importance of the $L C R$, located some $12-20 \mathrm{~kb} 5^{\prime}$ from the $\beta-g l o b i n$ gene, in the regulation of the $\beta$-globin gene cluster expression (Beris et al, 1992; Enver et al, 1990; Forester et al, 1986; Fraser et al, 1990; Grosveld et al, 1987; Tuan et al, 1985, Oner et a 1, 1992; Boehringer et al, 1990). It has been proposed that the disproportional increase in $\delta$ and $y$ chain production in cis to the deletions is due to the altered competition of the $\beta_{-}, \delta_{-}$, and $\gamma$-globin gene promoters for the LCR sequences (Boehringer et al, 1990; Waye et al, 1991; Dimorski et al, 1993). The loss of the $\beta$-globin gene promoter would allow the remaining $\delta$ and $\gamma$ promoters to react more readily with the enhancer element(s) located in the LCR. This hypothesis was supported by the fact that, although variable, the increased Hb $F$ levels were observed in the $B$-thal heterozygotes with the deletion of the $5^{\prime} \beta$-globin gene region. Although coexisting $\alpha$-thal has not been excluded in all the patients studied, the variable $\mathrm{Hb} F$ levels observed might be accounted for by the chromosomal background on which these deletions occur. Analyses of the $5^{\prime} \mathrm{HS}-2$ and $\mathrm{G}_{\gamma}$ promoter sequences suggest that the Croatian deletion occurs on a chromosome with characteristics of ${ }_{\beta} S$ haplotype $\# 3$ and $\beta$-thal haplotype IV. Adults with this type of chromosome are known to have increased $\gamma$ chain production (especially $G_{\gamma}$ ) during hematopoietic stress such as in SS disease (Oner et al, 1992), B-thal (Beris et al, 1992; unpublished data) or $\mathrm{Hb} \mathrm{H}$ disease (Curuk et al, 1993). The elevated $H b F$ (5.6 and 8.5\%) with high $G_{Y}$ levels (70\%) associated with the Croatian deletion support this hypothesis.

The absence of significant sequence homology of the deleted chromosome with the normal $5^{\prime}$ and $3^{\prime}$ sequences suggest that a non-homologous recombinant event is responsible for the Croatian deletion. Sequence-specific mechanisms such as the presence of direct repeats (Efstratiadis et al, 1980), junctional homology (Henthorn et al, 1990), AT-rich regions (Gonzalez-Redondo et al, 1989; The in et al, 1989), topoisomerase I recognition sequences (Konopka, 1988), and DNA polymerase a pause points (Anand et al, 1988; Weaver and DePamphilis, 1982) have been suggested in relation to DNA breakage in non-homologous recombination events. Of all these, only the junctional homology of the guanidine nt common to both ends has been observed in the Croatian deletion. However, the extensive study of non-homologous recombinations in the $\beta$-globin gene cluster leading to $\beta$-thal, $\delta \boldsymbol{\beta}$-thal, and HPFH, have revealed that the breakpoints of these deletions are extremely heterogeneous, occurring preferentially within transcriptional units of the cluster (Henthorn et al, 1990). The predominant mechanism of DNA breakage within a particular region might be related to the local chromatin structure and pattern of expression.

Acknowledgements. This study was supported by Yugoslav-American Joint Funds, pp 788, and Science Funds of the Republic of Macedonia 1095/89.

\section{REFERENCES}

Alter, B.P., Goff, S.C., Efremov, G.D., Gravely, M.E. \& Huisman, T.H.J. (1980) Globin chain electrophoresis: A new approach to the determination of the $G_{\gamma} A_{\gamma}$ ratio in fetal haemoglobin and to studies of globin synthesis. British Journal of Haematology, 44, 527-534. 
Anand, R., Boehm, C.D., Kazazian, H.H., Jr. \& Vanin, E.F. (1988) Molecular characterization of a $B$-thalassemia resulting from a $1.4 \mathrm{~kb}$ deletion. Blood, 72, 636-641.

Aulehla-Scholz, C., Speilberg, R. \& Horst, J. (1989) A B-thalassemia mutant caused by a 300 bp deletion in the human B-globin gene. Human Genetics, 81, 298-301.

Beris, Ph., Kitundu, M.N., Baysal, E., Oner, C., Lanclos, K.D., Dimovski, A.J., Kutlar, F. \& Huisman, T.H.J. (1992) Black B-thalassemia homozygotes with specific sequence variations in the 5 ' hypersensitive site-2 locus control region have high levels of fetal hemoglobin. American Journal of Hematology, 41, 97-101.

The $\beta$ - and $\delta$-Thalassemia Repository. (1992) Hemoglobin, 16, 237-258.

Betke, K., Marti, H.R. \& Schlicht, I. (1959) Estimation of small percentages of foetal haemoglobin. Nature, 184, 1877-1878.

Boehringer, R.R., Ryan, T.M., Palmiter, R.D., Brinster, R.L. \& Townes, T.M. (1990) Human $\gamma$ - to $\beta-g l o b i n$ gene switching in transgenic mice. Genes Development, $4,380-389$.

Codrington, J.F., Li, H-W., Kutlar, F., Gu, L-H., Ramachandrand, M. \& Huisman, T.H.J. (1990) Observations on the levels of $\mathrm{Hb}_{2} \mathrm{~A}_{2}$ in patients with different $\beta$-thalassemia mutations and a $\delta$ chain variant. Blood, 76, 12461249 .

Craig, J.E., Kelly, S.J., Barnetson, B. \& Thein, S.L. (1992) Molecular characterization of a novel $10.3 \mathrm{~kb}$ deletion causing $\beta$-thalassaemia with unusually high $\mathrm{Hb} \mathrm{A}_{2}$. British Journal of Haematology, 82, 735-744.

Curuk, M.A., Dimovski, A.J., Baysal, E., Gu, L-H., Kutlar, F., Molchanova, T.P., Webber, B.B., Altay, C., Gurgey, A. \& Huisman, T.H.J. (1993) Hb Adana or $\alpha_{2} 59$ (E8)Gly $\rightarrow A$ SPB $_{2}$, a severely unstable a l-globin variant, observed in combination with the $-(a) 20.5 \mathrm{~kb}$ a-thal-1 deletion in two Turkish patients. American Journal of Hematology, in press.

Diaz-Chico, J.C., Yang, K.G., Kutlar, A., Reese, A.L., Aksoy, M. \& Huisman, T.H.J. (1987) An 2300 bp deletion involving part of the $5^{\prime} \beta$-globin gene region is observed in members of a Turkish family with $B$-thalassemia. Blood, 70, 583-586.

Dimovski, A.J., Adekile, A.D. \& Huisman, T.H.J. (1993) The in vivo expression of the globin genes of the $\beta$ cistron in $\gamma-, \delta-$, and $\delta \beta$-thalassemia heterozygotes. Experientia, in press.

Efremov, G.D., Nikolov, N., Bakioglu, I. \& Huisman, T.H.J. (1986) The 18 to $23 \mathrm{~kb}$ deletion of the Macedonian $\delta_{\beta}$ thalassemia includes the entire $\delta$ and $B$ globin genes. Blood, 68, 971-974.

Efremov, G.D., Huisman, T.H.J., Bowman, K., Wrightstone, R.N. \& Schroeder, W.A. (1974) Microchromatography of Hemoglobins. II. A rapid chromatographic method for the determination of Hemoglobin $A_{2}$. Journal of Laboratory and Clinical Medicine, 83, 657-664.

Enver, T., Raich, N., Ebens, A.J., Papayannopolou, Th., Constantini, F. \& Stamatoyannopoulos, G. (1990) Developmental regulation of human fetalto-adult globin gene switching in transgenic mice. Nature, 344, 309-312.

Feinberg, A.P. \& Vogelstein, B. (1983) A technique for radiolabeling DNA restriction fragments to high specific activity. Analytical Biochemistry, 132, 6-13.

Felice, A.E., Cleek, M.P., Marino, E.M., McKie, K., McKie V.C., Chang, B.K. \& Huisman, T.H.J. (1986) Different $\boldsymbol{\zeta}$ globin gene deletions among Black Americans. Human Genetics, 73, 221-224.

Felice, A.E., Cleek, M.P., McKie, K., McKie, V. \& Huisman, T.H.J. (1984) The rare $\alpha$-thalassemia-1 of Blacks is a $\zeta \alpha$-thalassemia-1 associated with a deletion of all a- and $\boldsymbol{\zeta}$-globin genes. Blood, 63, 1253-1257. 
Forester, W.C., Thompson, C., Elder, J.T. \& Groudine, M. (1986) A developmentally stable chromatin structure in the human $\beta$-globin gene cluster. Proceedings of the National Academy of Sciences of the United States of America, 83, 1359-1363.

Fraser, P., Hurst, J., Collis, P. \& Grosveld, F. (1990) Dnase I hypersensitive sites 1,2 and 3 of human $\beta$-globin dominant control region direct position-independent expression. Nucleic Acids Research, 18, 3503-3510.

Gilman, J.G. (1987) The 12.6 kilobase DNA deletion in Dutch $\beta$-thalassaemia. British Journal of Haematology, 67, 369-372.

Gilman, J.G., Huisman, T.H.J. \& Abels, J. (1984) Dutch $\beta^{\circ}$-thalassaemia: A 10 kilobase DNA deletion associated with significant $\gamma$-chain production. British Journal of Haematology, 56, 339-348.

Gonzalez-Redondo, J.C., Kattamis, C. \& Huisman, T.H.J. (1989) Characterization of three types of $B$-thalassemia resulting from a partial deletion of the B-globin gene. Hemoglobin, 13, 377-392.

Grosveld, F., Blom van Assendelft, G., Greaves, D.R. \& Kollias, G. (1987) Position independent high level expression of the human B-globin gene in transgenic mice. Cell, 51, 975-985.

Henthorn, P.S., Smithies, O. \& Mager, D.L. (1990) Molecular analysis of deletions in the human $\beta$-globin gene cluster: Deletion junctions and locations of breakpoints. Genomics, 6, 226-237.

Huisman, T.H.J. \& Jonxis, J.H.P. (1977) The Hemoglobinopathies Techniques of Identification, Vol. 6, Marcel Dekker, Inc., New York.

Konopka, A.K. (1988) Compilation of DNA strand exchange sites for nonhomologous recombiantion in somatic cells. Nucleic Acids Research, 18, 1739-1758.

Lanclos, K.D., Oner, C., Dimovski, A.J. \& Huisman, T.H.J. (1991) Sequence variations in the $5^{\prime}$ flanking and IVS-II regions of the $G_{\gamma}$ and $A_{\gamma}$ globin genes of $\beta^{S}$ chromosomes with five different haplotypes. Blood, 77 , 2488-2496.

Lynch, J.R., Brown, J.M., Best, S., Jennings, M.W. \& Weathera11, D.J. (1991) Characterization of the breakpoint of a 3.5-kb deletion of the $B$ globin gene. Genomics, 10, 509-511.

Motum, P.I., Lindeman, R., Hamilton, T.J. \& Trent, R.J. (1992) Australian $\beta^{\circ}$-thalassaemia: A high Haemoglobin $A_{2} B^{\circ}$-thalassaemia due to a $12 \mathrm{~kb}$ deletion commencing $5^{\prime}$ to the B-globin gene. British Journal of Haematology, 82, 107-113.

Oner, C., Dimovski, A.J., Altay, C., Gurgey, A., Gu, Y.C., Huisman, T.H.J. \& Lanclos, K.D. (1992) Sequence variations in the $5^{\prime}$ hypersensitive site- 2 of the locus control region of ${ }_{\beta} S$ chromosomes are associated with different levels of fetal globin in Hemoglobin S homozygotes. Blood, 79, 813-819.

Padanilam, B.J., Felice, A.E. \& Huisman, T.H.J. (1984) Partial deletion of the $5^{\prime} \beta$-globin gene region causes $\beta^{\circ}$-thalassemia in members of an American Black family. Blood, 64, 941-944.

Poncz, M., Solowiejczyk, D., Harpel, B., Mory, Y., Schwartz, E. \& Surrey, S. (1982) Construction of human gene libraries from small amounts of peripheral blood: Analysis of B-like globin genes. Hemoglobin, 6, 27-36.

Popovitch, B.W., Rosenblatt, D.S., Kenda11, A.G. \& Nishioka, Y. (1986) Molecular characterization of an atypical B-thalassemia caused by a large deletion in the $5^{\prime} \beta$-globin gene region. American Journal of Human Genetics, 39, 797-810. 
Saiki, R.K., Gelfand, D.H., Stoffel, S., Scharf, S.J., Higuchi, R., Horn, G.T., Mullis, K.B. \& Erlich, H.A. (1988) Primer-directed enzymatic amplification of DNA with a thermostable DNA polymerase. Science, 239, 487-494.

Sanger, F., Nicklen, S. \& Coulson, A.R. (1977) DNA sequencing with chain-terminating inhibitors. Proceedings of the National Academy of Sciences of the United States of America, 74, 5463-5467.

Sanguansermsri, T., Pape, M., Laig, M., Hundrieser, J. \& Flatz, G. (1990) $B^{\circ}$-Thalassemia in a Tha family is caused by a $3.4 \mathrm{~kb}$ deletion including the entire B-globin gene. Hemoglobin, 14, 157-168.

Thein, S.L., Barnetson, R. \& Abdalla, S. (1992) A $\beta$-thalassemia variant associated with unusually high Henoglobin $A_{2}$ in an Iranian family. Blood, 79, 2801-2803.

Thein, S.L., Hesketh, C., Brown, J.M., Anstey, A.V. \& Weathera11, D.J. (1989) Molecular characterization of a high $A_{2}$ B-thalassemia by direct sequencing of single strand enriched amplified genomic DNA. Blood, 73, 924-930.

Tuan, D., Solomon, W., Qiliang, L. \& London, I.M. (1985) The "B-likeglobin" gene domain in human erythroid cells. Proceedings of the National Academy of Sciences of the United States of America, 82, 6384-6388.

Waye, J.S., Cai, S.P., Eng, B., Clark, C., Adams, J.G., III, Chui, D.H.K. \& Steinberg, M.H. (1991) High Hemoglobin $A_{2} \beta^{\circ}$-thalassemia due to a 532-basepair deletion of the $5^{\prime}$ B-globin gene region. Blood, 77, 1100-1103.

Weaver, D.T. \& DePamphilis, M.L. (1982) Specific sequences in native DNA that arrest synthesis of DNA polymerase a. Journal of Biological Chemistry, 257, 2075-2083. 


\title{
CHAPTER 4C
}

\section{A NOVEL DELETION OF थ27 KB INCLUDING THE B-GLOBIN GENE AND THE LCR 3 'HS-1 REGULATORY SEQUENCE: $\beta^{\circ}$-THALASSEMIA OR HPFH?}

\author{
A.J. Dimovski1, v. Divoky1, A.D. Adekile1, E. Baysal1, \\ J.B. Hilson 1 , J.F. Prior ${ }^{2}$, J.L. Raven ${ }^{2}$, and T.H.J. Huisman 1 \\ 1 Laboratory of Protein Chemistry and \\ Department of Biochemistry and Molecular Biology \\ Medical College of Georgia, Augusta, GA 30912-2100, USA \\ 2 Haematology Department, The Queen Elizabeth II Medical Centre \\ Sir Charles Gairdner Hospital, Nedlands 6009, Western Australia
}

[Adapted from: Blood, in press (1993)]

\begin{abstract}
A novel deletion of $227 \mathrm{~kb}$ with the $5^{\prime}$ breakpoint 1.5 to $2.2 \mathrm{~kb}$ upstream of the $\beta$-globin gene and the $3^{\prime}$ breakpoint $224 \mathrm{~kb}$ downstream of the B-globin gene has been found in five members of two families from Southeast Asia (Vietnam and Cambodia). Six members of another family from China, previously reported from our laboratory, have also been shown to carry this deletion. The patients presented with mild hypochromia and microcytosis, a $\mathrm{Hb} \mathrm{A}_{2}$ level of $\imath 4.0 \%$, and a markedly increased, heterocellularly distributed, Hb $F(14.0$ to 26.0\%). In vitro globin chain synthesis showed a mild imbalance with appreciable $Y$ chain compensation $(\alpha \beta+\gamma$ ratio of 1.46$)$. The $3^{\prime}$ end of this deletion includes the $3^{\prime} H S-1$ and we hypothesize that removal of this region results in the loss of its $\gamma$-globin gene silencing effect, which causes a markedly elevated $H b F$ with a modest increase in $\mathrm{Hb}_{2}$ levels, unlike the situation in other deletional $\beta^{\circ}$-thalassemias.
\end{abstract}




\section{INTRODUCTION}

The developmental stage-specific sequential transcription of the genes of the $\beta$-globin gene cluster from $\varepsilon-\lambda_{\gamma}-\lambda_{-}->_{\beta}$ is controlled by several complex factors $(1,2)$. Elucidation of the mechanisms involved may have implications for the ultimate clinical management of $\beta-g l o b i n$ gene disorders, especially SS disease and B-thal $(2,3)$.

Genetic disorders which alter Hb switching have provided natural molecular models for studying sequence variations modulating the expression of the genes of the $\beta-g l o b i n$ gene cluster. $(\delta \beta)^{\circ}$-Thalassemias and HPFH are characterized by continuing expression of $\gamma$-globin genes in adults and are caused by deletions or point mutations within the $\beta$-globin gene cluster. The two are distinguished by phenotypic differences exhibited by heterozygotes. In the former there is heterocellular distribution of $\mathrm{Hb} F$ and red cell microcytosis and hypochromia. On the other hand, heterozygotes for deletional HPFH determinants do not show microcytosis or hypochromia and usually have higher $\mathrm{Hb} F$ levels with a pancellular homogeneous distribution (4). However, these differences may not always be clear-cut and it may be difficult to differentiate $B^{\circ}$-thal and HPFH using hematological criteria.

We have recently encountered five members of two families originally from Southeast Asia (Vietnam and Cambodia) who presented with mild microcytosis and hypochromia, with a pronounced elevation of $\mathrm{Hb} F$ ranging from 14.0 to $26.0 \%$ ( ${ }^{G} Y$ of $60.0-70.0 \%$ ), and with $\mathrm{Hb} \mathrm{A}_{2}$ levels of $24.0 \%$. Molecular characterization demonstrated a novel deletion of $227 \mathrm{~kb}$ in the $\beta$-globin gene cluster which extends 1.5 to $2.2 \mathrm{~kb}^{\prime}$ ' and $224 \mathrm{~kb} 3^{\prime}$ to the $B$ gene. In this report, details of in vitro globin chain synthesis, Hb $F$ distribution, and the molecular characterization of this new deletion are presented, and the possible mechanisms of the enhanced $\gamma$ gene expression are discussed.

\section{MATERIALS AND METHODS}

Family N. This family is of Vietnamese origin, but currently resides in the Southeastern United States (Georgia). The propositus (D.N.) is a 15-year-old male, who presented with $22.3 \% \mathrm{Hb} \mathrm{F}$. He had no anemia, but exhibited mild microcytosis and hypochromia (Table $4 \mathrm{c} / 1$ ). The father and a sister had normal hematological data with $<1.0 \% \mathrm{Hb} F$, but the mother had a $\mathrm{Hb} F$ level of $20.1 \%$ with mild microcytosis and hypochromia.

Family $K$. This family is of Cambodian origin but currently live in Australia. Three members of the family presented with elevated $H b F$ levels with mild hypochromia and microcytosis (Table 4c/1).

Hematology. Complete blood counts and red cell indices were obtained with an automated cell counter (Sysmex). The $\mathrm{Hb} \mathrm{F}$ and $\mathrm{Hb} \mathrm{A}_{2}$ were quantified by cation exchange HPLC $(5,6)$. The relative quantities of the $G_{\gamma}$ and $A_{\gamma}$ chains were determined by reversed phase HPLC $(7,8)$. In vitro globin chain synthesis was done on freshly-collected blood from the propositus (D.N.) using standard methodology (9). The distribution of Hb $F$ was evaluated by the acid elution method of Kleihaver et al (10), by fluorescent anti-Hb F 
monoclonal antibody staining (11), and by HPLC quantitation in different fractions obtained by dextran density gradient centrifugation (12). These tests were done on freshly-collected blood samples from D.N. and two controls, a heterozygous HPFH-2 individual with a total Hb $F$ level of $29.0 \%$ (pancellular distribution) and a homozygous $B^{+}$-thal $\left.[-88, C->T)\right]$ with a total Hb F level of $41.4 \%$ (heterocellular distribution).

TABLE 4C/1. Hematological Data for the Patients Studied

\begin{tabular}{ccccccccccc}
\hline Case & Sex- & $\mathrm{Hb}$ & $\mathrm{RBC}$ & $\mathrm{PCV}$ & $\mathrm{MCV}$ & $\mathrm{MCH}$ & $\mathrm{A}_{2}$ & $\mathrm{~F}$ & $\mathrm{G}_{\gamma}$ & \#a \\
& Age & $\mathrm{g} / \mathrm{dl}$ & $1012 / 1$ & $\mathrm{l} / 1$ & $\mathrm{fl}$ & $\mathrm{pg}$ & $\%$ & $\%$ & $\%$ & Genes \\
\hline
\end{tabular}

Family N

$\begin{array}{lllllllllll}\text { P.B.T. } & \text { F-adult } & 15.1 & 6.16 & 0.473 & 76.8 & 24.5 & 4.1 & 20.1 & 62.9 & \text { aa /aa } \\ \text { D.N. } & \text { M-15 } & 16.2 & 6.18 & 0.492 & 79.6 & 26.2 & 4.0 & 23.8 & 62.5 & \text { aa /aa }\end{array}$

Family $\mathrm{K}$

$\begin{array}{lllllllllll}\text { T.K. } & \text { M-33 } & 16.4 & 6.90 & 0.555 & 80.0 & 23.8 & 5.1 & 16.6^{\star} & 62.1 & \text { n.d. } \\ \text { K.K. } & \text { F- } 8 & 12.7 & 5.25 & 0.420 & 80.0 & 24.2 & 4.1 & 20.5^{\star} & 61.5 & -\alpha / \alpha a \\ \text { S.K. } & \text { F- } 6 & 11.4 & 5.29 & 0.400 & 76.0 & 21.6 & 4.8 & 14.1^{\star} & 60.4 & -\alpha /-\alpha\end{array}$

* These $\mathrm{Hb} F$ levels are lower than those in the two members of Family $\mathrm{N}$ because of a coexisting a-tha 1-2; the father T.K. has to be at least an a-thal-2 heterozygote.

Restriction Endonuclease Mapping. DNA was isolated from peripheral blood leukocytes with the method of Poncz et al (13). Two affected members of Family N (D.N. and P.B.T.), one member (K.K.) from Family K, and a normal control were studied. Five $\mu \mathrm{g}$ of DNA was digested with various restriction endonucleases (Bam HI, Xba I, Hind III, BgI II, Eco RI, Hpa I), electrophoresed on $0.8 \%$ agarose gel transferred to nylon membranes (Hybond $\mathrm{N}^{+}$, Amersham) and hybridized to $32 p$-labeled probes as described previously $(14,15)$. The following genomic DNA fragments were used as probes: $1 \mathrm{~kb}$ Eco RI/Bam HI fragment ( $\delta$-IVS-II probe); $1.8 \mathrm{~kb}$ Bam HI fragment ( $5^{\prime}$ B probe); $1.2 \mathrm{~kb}$ Bam HI/Eco RI fragment ( $\beta$-IVS-II probe); $1.2 \mathrm{~kb}$ Eco RI fragment located $220 \mathrm{~kb}$ from the $\beta$ gene (pRK 29 probe); $0.75 \mathrm{~kb}$ Hinf I/Eco RI sub-fragment (0.75 kb probe), isolated from the $1.1 \mathrm{~kb}$ Bam HI/Bgl II DNA fragment which was derived from the $3^{\prime}$ breakpoint of the HPFH-3 deletion located $230 \mathrm{~kb}$ $3^{\prime}$ to the $\beta$-globin gene (16); $0.5 \mathrm{~kb}$ Hind III fragment ( $\mathrm{p} 500 \mathrm{H}$ probe) located $270 \mathrm{~kb} 3^{\prime}$ to the $\beta$ gene; and the $1 \mathrm{~kb} B g l$ II/ECo RI fragment (3D probe) derived from the $3^{\prime}$ breakpoint of the HPFH-1 deletion (17).

a-Globin Genotype. All individuals under study were screened for $\alpha$-thal deletions with methodology routinely used in our laboratory (18-20).

Sequencing Analysis of the LCR 5'HS-2, $G_{Y}$ and $A_{Y}$ Promoter Regions, and the $\delta$-6lobin Gene. The $750 \mathrm{bp}$ Hind III/Bgl II fragment of the LCR $5^{\prime} H S-2,21.3 \mathrm{~kb} \mathrm{5'}$ flanking region of both the ${ }^{2}$-and $A_{r}$ globin genes, and the entire $\delta$-globin gene including 200 bp of the $5^{\prime}$ and $3^{\prime}$ flanking regions were amplified and analyzed by direct sequencing. The details of the procedures have been described previous 1 y $(21-23)$. 


\section{RESULTS}

Henatology. Table $4 c / 1$ shows the hematological data for the members of the two families. In Family N, the average $\mathrm{MCV}$ in the two affected members was $78.2 \mathrm{fl}$, while the $\mathrm{MCH}$ was $25.4 \mathrm{pg}$, $\mathrm{Hb} \mathrm{A} 24.0 \%$, Hb F $22.0 \%$, and $\mathrm{Gr}_{\mathrm{r}}$ 62.7\%. In Family $\mathrm{K}$ the corresponding values were $\mathrm{MCV} 78.7 \mathrm{fl}, \mathrm{MCH} 23.2 \mathrm{pg}$, $\mathrm{Hb} \mathrm{A} \mathrm{A}_{2} 4.7 \%, \mathrm{Hb} \mathrm{F} 17.1 \%$, and $\mathrm{G}_{\gamma} 61.3 \%$. In vitro chain analysis for D.N. showed an $\alpha / \beta$ ratio of 1.98 which is consistent with a single gene deletion and an $\alpha / \beta^{+} \gamma$ ratio of 1.46 , demonstrating appreciable $\gamma$ chain compensation.

With both the acid elution method and the fluorescent monocional antibody staining, the $\mathrm{Hb} \mathrm{F}$ distribution in D.N. Was heterogeneous and $H b F$ was present in most erythrocytes (>95.0\%). The distribution was much more heterocellular ( $85.0 \% \mathrm{~F}$ cells) in the $\beta$-thal control, while the distribution was distinctly pancellular and homogeneous in the HPFH control. Dextran density gradient centrifugation yieided six fractions each for D.N. and the HPFH control, while in the $B$-thal control the top two fractions were indistinct. The variation of $\mathrm{Hb} \mathrm{F}$ in the different fractions was within a narrow range of 23 to $31.2 \%$ in the HPFH control. A much wider range of 20.7 to $49.5 \%$ was observed in the B-thal control, while in D.N. it was intermediate between the two, with a range of 12.6 to $30.1 \%$ (Table 4c/2). The $G_{\gamma}$ levels in the different fractions remained virtually unchanged in all three individuals (data not shown). The levels of $\mathrm{Hb}_{2}$ remained fairly constant in the HPFH control, while there was an inverse relationship between $\mathrm{Hb} \mathrm{A}_{2}$ and $\mathrm{Hb} \mathrm{F}$ in the 8 -thal control and the propositus D.N.

TABLE 4c/2. Dextran Density Fractionation: The Quantities of $H b s$ and $A_{2}$
D.N.*
P.0.*
Jo.S.*

\begin{tabular}{|c|c|c|c|c|c|c|c|c|}
\hline $\begin{array}{c}\text { Fraction } \\
(\%)\end{array}$ & $\% \mathrm{~F}^{\S}$ & $\mathrm{KA}_{2} \S$ & $\begin{array}{l}\text { Fraction } \\
(\mathscr{x})\end{array}$ & qF & $\mathrm{AA}_{2}$ & $\begin{array}{l}\text { Fraction } \\
(\%)\end{array}$ & qF & $\% A_{2}$ \\
\hline 1a. $(10.0)$ & 12.6 & 5.5 & 1a. $(1.1)$ & 23.0 & 1.7 & 1. $(10.0)$ & 20.7 & 11.4 \\
\hline 1b. $(35.0)$ & 19.6 & 5.3 & 1b. $(4.2)$ & 23.3 & 1.8 & & & \\
\hline 2. $(30.0)$ & 28.1 & 3.7 & 2. $(30.6)$ & 26.3 & 2.0 & 2. (27.5) & 39.7 & 8.3 \\
\hline 3. $(15.0)$ & 30.1 & 3.4 & 3. $(34.6)$ & 31.2 & 1.8 & 3. $(35.0)$ & 49.5 & 6.6 \\
\hline 4. $(5.0)$ & 30.0 & 3.3 & 4. (26.3) & 31.2 & 1.8 & 4. $(22.5)$ & 46.0 & 7.2 \\
\hline 5. $(5.0)$ & 20.4 & 4.5 & 5. $(3.2)$ & 27.3 & 1.6 & 5. $(5.0)$ & 33.2 & 9.4 \\
\hline Total: & 26.3 & 3.7 & & 29.0 & 2.1 & & 41.4 & 8.0 \\
\hline
\end{tabular}

D.N. = propositus; P.O. = heterozygous for HPFH-2; Jo.S. = homozygous for $B$-thal $[-88,(C->T)]$.

$\$$ By cation exchange HPLC $(5,6)$.

Restriction Endonuclease Mapping of the 5' and 3' Breakpoints. Hybridization with the 5'B, B-IVS-II, and PRK 29 probes did not show any abnormal fragments, but the intensity of the normal fragments obtained in the three patients was about half compared to that of the control DNA, suggesting 
a deletion that removes the entire B-globin gene and a large portion of its $3^{\prime}$ flanking region (data not shown). Hybridization with the $\delta$-IVS-II probe showed abnormal fragments of $8.5 \mathrm{~kb}$ and $10.3 \mathrm{~kb}$ with $\mathrm{Xba} I$ and $\mathrm{Bg}$ I II restriction enzymes, respectively, while no abnormal fragments were detected with Hind III, Hpa I, Eco RI, and Bam HI. This indicates that the 5 ' breakpoint of the deletion is within the $700 \mathrm{bp} \mathrm{Bam} \mathrm{HI/Bgl}$ II fragment located at -2255 to -1559 relative to the $\beta-g$ lobin gene Cap site (Fig. $4 \mathrm{C} / 1)$.

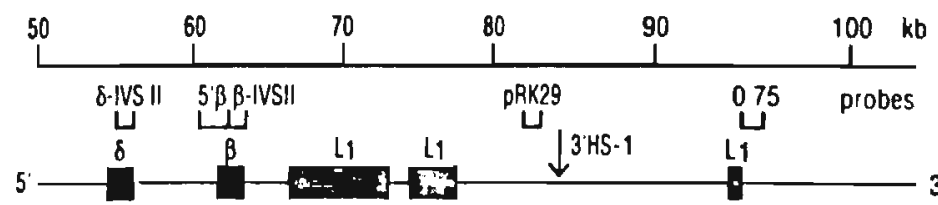

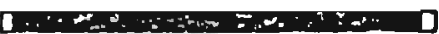

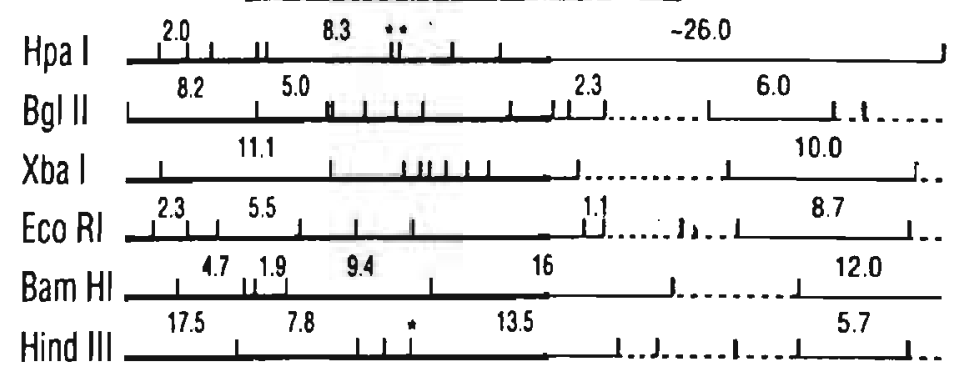

Abnormal fragments observed with:

$\frac{\delta \text {-IVS II probe }}{\text { none }} \frac{0.75 \text { probe }}{17.0 \mathrm{~kb}}$

$10.3 \mathrm{~kb}$ none

$8.5 \mathrm{~kb} \quad$ none

none none

none none

none none

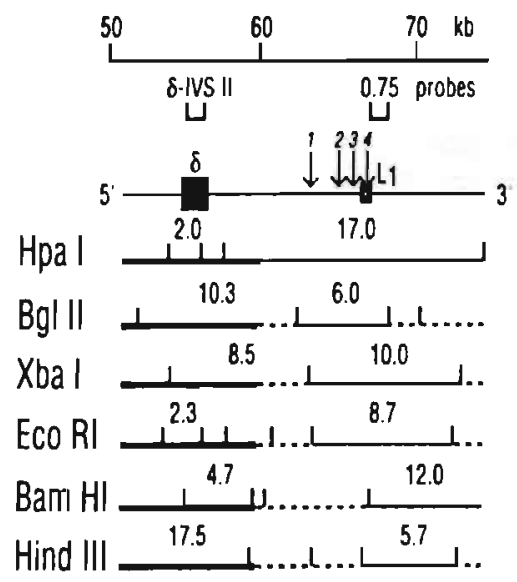

FI6. 4c/1. Restriction map of the SEA deletion. Top: A map of the normal chromosome with the deletion indicated below as the black bar; regions of uncertainty are shown as open bars. The scale shown at the top is relative to the projected coordinates in the GenBank file HUMHBB. The positions of the two $L 1$ repeats closer to the $B-g l o b i n g e n e$ are from Ref. 43, whereas the mapping of the $3^{\prime} \mathrm{LI}$ repeat, which is only partially characterized, is from Ref. 16. The positions of the restriction enzyme sites within the bold lines are derived from the sequence analyses of the GenBank file HUMHBB. The positions and sizes of the fragments observed with the 0.75 probe are as described in Ref. 16. The region between the PRK 29 and 0.75 probes (shown by dotted lines) is from Ref. 28. Asterisks (*) indicate polymorphic restriction sites. Bottom: A deduced restriction map of the chromosome with the SEA deletion. The numbers $1,2,3$, and 4 refer to the $3^{\prime}$ breakpoints of the German $\left.{ }^{G} \gamma^{A} \gamma \delta \beta\right)^{\circ}$-thal, Italian HPFH, Belgian $\left.{ }^{G} \gamma^{A}{ }_{\gamma \delta \beta}\right)^{\circ}-$ thal, and Indian HPFH deletions, respectively. 
To establish the $3^{\prime}$ breakpoint, the membrane was rehybridized with the $0.75, \mathrm{p} 500 \mathrm{H}$, and 30 probes. Analysis with $\mathrm{p} 500 \mathrm{H}$ and 30 probes did not reveal any abnormal fragments and the intensity was not reduced, suggesting that the $3^{\prime}$ breakpoint is located upstream of the Hpa I site $5^{\prime}$ to the $\mathrm{p50OH}$ probe. Hybridization with the 0.75 probe showed an abnormal fragment of $17 \mathrm{~kb}$ with $\mathrm{Hpa}$ I, while the other restriction enzymes did not show any abnormal nor less intense fragments. This suggests that the $3^{\prime}$ breakpoint of the deletion is located within the $27 \mathrm{~kb}$ fragment some 20 to $27 \mathrm{~kb} 3^{\prime}$ from the $B-g l o b i n g e n e$ between the PRK 29 probe and the Bgl II site 5 ' from the $3^{\prime} 0.75$ probe. From the maps available for deletions with $3^{\prime}$ breakpoints within this vicinity, [HPFH-3 (24), HPFH-4 (25), and the German (26) and Belgian (27) $G_{\gamma}\left(A_{\gamma \delta \beta}\right)^{\circ}$-thal], the map of the $3^{\prime} H S-1$ localization (28), and from the sizes of the abnormal fragments detected in the Xba I, Bgl II and Hpa I digests, the $3^{\prime}$ breakpoint was localized to $224 \mathrm{~kb} 3^{\prime}$ to the $\beta$ globin gene (Fig. 4c/1, top). The deduced restriction map of the chromosome carrying the deletion is shown in Fig. $4 \mathrm{c} / 1$ (bottom). From the preceding data, the total length of the deletion is $\sim 27 \mathrm{~kb}$ including the entire B-globin gene, $\sim 2 \mathrm{~kb}$ of the $5^{\prime}$, and $\sim 24 \mathrm{~kb}$ of the $3^{\prime}$ flanking regions.

a-Globin Genotype. In Family K, S.K. was homozygous, while K.K. was heterozygous for the a-thal-2 (-a 3. $\left.^{3} \mathrm{~kb}\right)$ deletion. DNA was not available for studies on T.K. The two members of Family $N$ each had a full complement of four $\alpha-g l o b i n g e n e s$.

LCR $5{ }^{\prime} H S-2,6_{Y}$ and $A_{Y}$ Promoter, and $\delta$-6lobin Gene Sequences. Sequencing analysis was performed on the DNA sample from P.B.T. The LCR 5'HS-2 sequence was identical to the reference sequence except for the AT repeat motif located at -10570 to -10623 relative to the Cap site of the $\varepsilon$-globin gene, which showed the (AT)gACACATATACGT(AT) 10 motif previously observed in $\beta$ S haplotype \#3 chromosomes (21). The only observed sequence variation in the $G_{Y}$ promoter was the $-158(C->T)$ substitution which creates an $X m n$ I restriction enzyme site. The $A_{\gamma}$ promoter and the $\delta$-globin gene sequence analyses did not show any variations from the reference sequence.

\section{DISCUSSION}

The novel SEA deletion described in the patients in this study is $\approx 27 \mathrm{~kb}$ with the $5^{\prime}$ breakpoint between the Bam $\mathrm{HI}$ and $\mathrm{Bgl}$ II sites $\approx 1.5$ to $2.2 \mathrm{~kb}$ upstream of the $B-g$ lobin gene, and the $3^{\prime}$ breakpoint $\sim 24 \mathrm{~kb}$ downstream of the $B-g l o b i n$ gene.

After completing the studies of the two families in this report, we reexamined six members of a Chinese family $(\mathrm{Zh})$ that was previously reported from this laboratory as having an uncharacterized HPFH condition (29). The hematology of the members of this family is similar to that of the two families in the present study, with $\mathrm{MCV}$ values of $87-98 \mathrm{fl}$, Hb $\mathrm{A}_{2}$ levels of 2.7 to $4.0 \%$, and with $\mathrm{Hb} \mathrm{F}$ levels of 17.5 to $26.6 \%$. The published gene mapping data of the $\mathrm{Zh}$ family were obtained using the probes available at that time, i.e. $\varepsilon, \gamma-I V S-I I$, inter- $\gamma, \psi B, \beta-I V S-I I$, and pRK 28 , which could not detect the SEA deletion. However, repeat studies using the $\delta$-IVS-II and 0.75 probes have established that all six members of this family are 
indeed heterozygous for a deletion which is identical to that in the present report. Thus, 11 members of three Southeast Asian families are known to have the deletion.

The hematological data for these patients are rather atypical. The markedly increased $H b F$ levels would suggest an HPFH condition, whereas the increased levels of $\mathrm{Hb}_{2}$, mild hypochromia and microcytosis favor a diagnosis of $\beta$-thal. The in vitro chain synthesis $(\alpha / \beta+\gamma$ ratio of 1.46$)$ shows appreciable $\gamma$ chain compensation, but the heterocellular distribution of the $H \mathrm{H} F$ by the acid elution test, the fluorescent monoclonal antibody staining, and the density fractionation, indicates that this deletion is associated with a $\beta$-thalassemic phenotype.

Eleven other deletions ranging from $44 \mathrm{bp}$ to $12.6 \mathrm{~kb}$ with complete or partial removal of the $\beta-g l o b i n$ gene have been described (30). In nine (shown in Fig. 4c/2) the promoter region is removed and heterozygotes exhibit typical microcytosis and hypochromia with marked $\mathrm{Hb}_{2}$ elevation (5.5 to $9.0 \%$ ) and a modest increase in $\mathrm{Hb} \mathrm{F}(0.2$ to $11.7 \%)$. It has been postulated that the disproportional increase in $\delta$ and $\gamma$ chain production in cis to these deletions is due to the altered competition of the $B-$, $\delta-$, and $\gamma$-globin gene promoters for the $5^{\prime}$ LCR regulatory sequences located upstream of the $\varepsilon$-globin gene $(31,32)$. Unlike these other deletional $B^{\circ}$ thalassemias, the SEA deletion is associated with lower $\mathrm{Hb} \mathrm{A}_{2}$ and much higher $\mathrm{Hb} F$ levels. In size, it is comparable to deletions causing the HPFH and $(\delta \beta)^{\circ}$-thal syndromes.

Several mechanisms have been proposed to explain the elevated $H b F$ levels in deletional HPFH and $(\delta \beta)^{\circ}$-thal syndromes. The region of DNA $3^{t}$ to the breakpoint of HPFH-1 and HPFH-2 contains cis-acting elements capable of up-regulating $r$ gene expression when translocated to the vicinity of $Y$ genes by these deletions (33). An erythroid-specific enhancer element has also been described immediately $3^{\prime}$ to the breakpoints of four deletions associated with marked $\mathrm{Hb} F$ elevation (34), i.e. the Indian and Italian HPFH (HPFH-3 and HPHF-4, respectively), and the German and Belgian $\left.{ }^{G} \gamma^{(A}{ }_{\gamma} \delta \beta\right)^{\circ}$-thal (Fig. 4c/2). Since the $3^{\prime}$ breakpoint of the SEA deletion is only 3-4 kb upstream from this region, the juxtaposition of the proposed enhancer elements might be responsible for the markedly increased $\mathrm{Hb} F$ levels in the patients studied. However, it is interesting that the intact $\delta$ gene in the SEA deletion is closer to the juxtaposed enhancer but is not over-expressed in comparison to the other deletional $B^{\circ}$-thalassemias. Although a direct preferential effect of the juxtaposed enhancer on $\gamma$ - rather than $\delta-g l o b i n$ gene expression cannot be ruled out, other alternative mechanisms might be involved.

The SEA deletion is the only deletional $B^{\circ}$-thal removing the $3^{\prime} H S-1$ sequence. The individual contribution of the latter to the overall LCR regulatory function has not been fully characterized. However, recent findings in transgenic mice have shown that the addition of the $3^{\prime} \mathrm{HS}-1$ sequence facilitates the down-regulation of $5^{\prime}$ LCR-y constructs in adult erythroid tissues $(2,35)$. We are therefore tempted to hypothesize that the marked increase in gene expression in our patients, as well as in other deletions with $3^{\prime}$ breakpoints in the same vicinity, may be due to the loss of the $3^{\prime} H S-1$ sequence. The loss of the latter leaves the control of the $\beta$-globin 
gene cluster expression solely to the $5^{\prime}$ LCR sequences, whose regulatory effect on the individual genes is influenced by proximity $(36,37)$. Thus, the closer genes are expressed preferentially over the $\delta$-globin genes in contrast to the findings in other deletional $\beta^{\circ}$-thalassemias where the 3'HS-1 sequence is preserved.

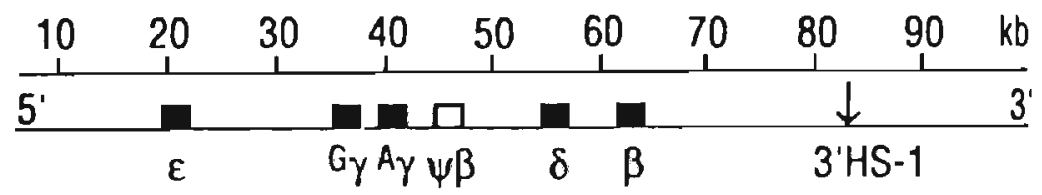

$\left(\beta^{\circ}\right)$ Thal

Turkish (290bp)

Black (532bp)

Black (1393bp)

Croatian (1605bp)

Thai (3.4kb)

Czech (4237bp)

Asian Indian (10.3kb)

Australian (12.0kb)

Dutch (12.6kb)

S.E. Asian ( 27kb)

$\mathrm{G}_{\gamma}\left(A_{\gamma} \delta \beta\right)^{\circ}$ Thal

Belgian ( $50 \mathrm{~kb})$

German ( $\sim 52 \mathrm{~kb})$

HPFH

Indian ( $48.5 \mathrm{~kb})$

Italian ( $42 \mathrm{~kb})$
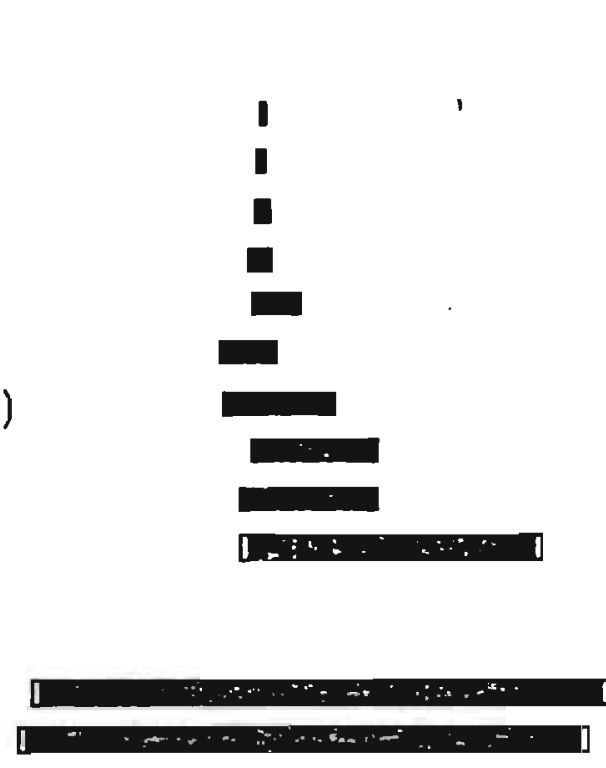

$14.2-14.8$

$9.9-12.5 \quad 2.4-2.6$

Heterozygotes

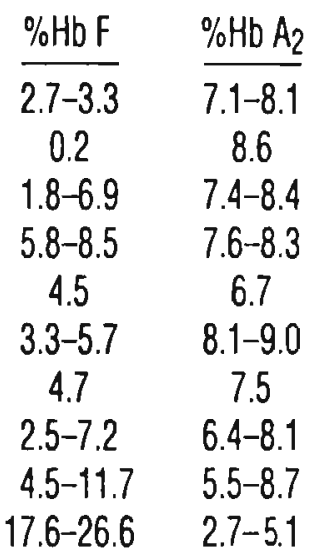

FI6. 4C/2. A map of deletional $B^{\circ}$-thalassemias involving the promoter region of the $B$-globin gene, and four deletions with $3^{\prime}$ breakpoints in the same vicinity as that of the SEA deletion. The levels of $\mathrm{Hb} \mathrm{A}_{2}$ and $\mathrm{Hb} F$ in heterozygotes for each of them are also shown.

The chromosomal background on which these deletions occur may also be important in the overall Hb $F$ expression. Previous reports from this laboratory have implicated certain sequence variations in the LCR 5'HS-2 (21) and the $G_{Y}$ promoter (22) with increased $\gamma$ expression. In the former, the (AT)gACACATATACGT(AT) 10 motif at position -10570 to -10623 relative to the $\varepsilon$ Cap site, is found on several chromosomes [including $\beta S$ (21), $B$-tha] (38), and $B A$ with coexistent severe a chain deficiency (39)] associated with high $H D F$ levels. In the $G_{Y}$ promoter, the $-158(C->T)$ substitution is almost always associated with high $G_{\gamma}$ and often high $H b F$ levels $(22,40)$. Interestingly, the chromosome with the SEA deletion in this study demonstrated these two sequence variations. Although their functional significance has not been completely elucidated, some ubiquitous and erythroid nuclear proteins have been reported to bind to these regions $(41,42)$. 
This chromosomal background could be capable of conferring high Hb $F$ expression, especially in conditions associated with erythropoietic stress.

Acknowledgements. The authors are indebted to Dr. Z-R. Ren for DNA samples from the Chinese Family $\mathrm{Zh}$. This study was supported by the USPHS research grant HLB-41544.

\section{REFERENCES}

1. Choi OR, Engel JD: Developmental regulation of $B-g l o b i n g e n$ switching. Cell 55:17, 1988

2. Orkin SH: Globin gene regulation and switching: Circa 1990. Cell 63:665, 1990

3. Adekile AD, Huisman THJ: $H b F$ in sickle cell anemia. (Experientia, in press)

4. Bollekens J, Forget BG: $\delta \beta-T h a l a s s e m i a$ and hereditary persistence of fetal hemoglobin. Hematol/Oncol Cl in N Am 5:399, 1991

5. Bisse E, Wieland H: High-performance liquid chromatographic separation of human haemoglobins - Simultaneous quantitation of foetal and glycated haemoglobins. J Chromatogr 434:95, 1988

6. Kutlar A, Kutlar F, Gu L-G, Mayson SM, Huisman THJ: Fetal hemoglobin in normal adults and $\beta$-thalassemia heterozygotes. Hum Genet 85:106, 1990

7. Shelton JB, Shelton JR, Schroeder WA: High performance liquid chromatographic separation of globin chains on a large-pore $\mathrm{C}_{4}$ column. J Liq Chromatogr 7:1969, 1984

8. Kutlar A, Kutlar F, Huisman THJ: Separation of normal and abnormal hemoglobin chains by reversed-phase high-performance liquid chromatography. J Chromatogr 357:147, 1986

9. Huisman THJ, Jonxis JHP: The Hemoglobinopathies Techniques for Identification. Clinical and Biochemical Analysis, Vol. 6. New York, NY, Marcel Dekker, 1977

10. Kleihauer E, Braun H, Betke K: Demonstration von fetalum Hamoglobin in den erythrozyten eines Blutausstriches. K1 in Wochenschr 35:637, 1957

11. Epstein N: Personal communication

12. Kutlar A, Kutlar F, Wilson JB, Headlee MG, Huisman THJ: Quantitation of hemoglobin components by high performance cation-exchange liquid chromatography. Its use in diagnosis and in the assessment of cellular distribution of hemoglobin variants. Am J Hematol 17:39, 1984

13. Poncz M, Solowiejczyk D, Harpel B, Mory Y, Schwartz E, Surrey S: Construction of human gene libraries from small amounts of peripheral blood: Analysis of $\beta$-like globin genes. Hemoglobin 6:27, 1982

14. Gilman JG: The 12.6 kilobase deletion in Dutch $\beta^{\circ}$-thalassaemia. $\mathrm{Br} J$ Haematol $67: 369,1987$

15. Hattori Y, Kutlar F, Kutlar A, McKie VC, Huisman THJ: Haplotypes of $\beta^{S}$ chromosomes among patients with sickle cell anemia from Georgia. Hemoglobin 10:623, 1986

16. Henthorn PS, Mager DL, Huisman THJ, Smithies 0: A gene deletion ending within a complex array of repeated sequences $3^{\prime}$ to the human B-globin gene cluster. Proc Natl Acad Sci USA 83:5194, 1986 
17. Tuan D, Feingold E, Newman M, Weissman SM, Forget BG: Different $3^{\prime}$ endpoints of deletions causing $\delta \beta$-thalassemia and hereditary persistence of fetal hemoglobin: Implications for the control of $\gamma$-globin gene expression in man. Proc Natl Acad Sci USA 80:6937, 1983

18. Felice $A E$, Cleek MP, McKie K, McKie V, Huisman THJ: The rare a-thalassemia-1 of Blacks is a ca-thalassemia-1 associated with deletion of all $a$-and $\zeta$-globin genes. Blood 63:1253, 1984

19. Felice AE, Cleek MP, Marino EM, McKie K, McKie VC, Chang BK, Huisman THJ: Different $\boldsymbol{\zeta}$ globin gene deletions among Black Americans. Hum Genet 73: 221, 1986

20. Baysal E, Huisman THJ: Detection of cormon a-thalassemia-2 determinants by PCR. (in preparation)

21. Oner C, Dimorski AJ, Altay C, Gurgey A, Gu YC, Huisman THJ, Lanclos KD: Sequence variations in the $5^{\prime}$ hypersensitive site-2 of the locus control region of ${ }_{B} S$ chromosomes are associated with different levels of fetal globin in Hemoglobin S homozygotes. Blood 79:813, 1992

22. Lanclos KD, Oner C, Dimovski AJ, Gu Y-C, Huisman THJ: Sequence variations in the $5^{\prime}$ flanking and IVS-II regions of the $G_{\gamma-}$ and $A_{\gamma-g l o b i n}$ genes of ${ }_{\beta} S$ chromosomes with five different haplotypes. Blood 77:2488, 1991

23. Li H-W, Codrington JF, Schiliro G, Wadsworth LD, Beris Ph, Adekile $A D$, Huisman THJ: The usefulness of sequence analysis of amplified DNA for the identification of $\delta$ chain variants. Hemoglobin 15:77, 1991

24. Kutlar A, Gardiner MB, Headlee MG, Reese AL, Cleek MP, Nagle S, Sukumaran PK, Huisman THJ: Heterogeneity in the molecular basis of three types of hereditary persistence of fetal hemoglobin and the relative synthes is of the $G_{Y}$ and $A_{\gamma}$ types of $\gamma$ chain. Biochem Genet 22:21, 1984

25. Ottolenghi $S$, Giglioni $B$, Taramelli $R$, Comi $P$, Mazza U, Saglio G, Camaschella C, Izzo P, Cao A, Galanello R, Gimferrer E, Baiget M, Gianni AM: Molecular comparison of $\delta \beta$-thalassemia and hereditary persistence of fetal hemoglobin DNAs: Evidence of a regulatory area? Proc Natl Acad Sci USA 79:2347, 1982

26. Anagnou NP, Papayannopoul ou Th, Nienhuis AW, Stamatoyannopoulos G: Molecular characterization of a novel form of $\left(A_{\gamma \delta} \delta\right)^{\circ}$-thalassemia deletion with a $3^{\prime}$ breakpoint close to those of HPFH-3, HPFH-4: Insights for a common regulatory mechanism. Nucleic Acids Res 16:6957, 1988

27. Losekoot M, Fodde R, Gerritsen EJA, van de Kuit I, Schreuder A, Giordano PC, Vossen M, Bernini LF: Interaction of two different disorders in the $\beta-g l o b i n$ gene cluster associated with an increased Hemoglobin $F$ production: A novel deletion type of $\mathrm{G}^{+}{ }^{+}\left({ }^{A} \gamma \delta \beta\right)^{\circ}$-thalassemia and a $\delta^{\circ}$-hereditary persistence of fetal hemoglobin determinant. Blood 77:861, 1991

28. Grosveld F, Blom van Assendelft G, Greaves DR, Kollias G: Position-independent, high-level expression of the human $\beta$-globin gene in transgenic mice. Cell 51:975, 1987

29. Zeng $Y-T$, Huang $S-Z$, Chen $B$, Liang $Y-C$, Chang $Z-M$, Harano $T$, Huisman THJ: Hereditary persistence of fetal hemoglobin or $(\delta B)^{\circ}$-thalassemia: Three types observed in South-Chinese families. Blood 66:1430, 1985

30. Dimovski $A J$, Efremov $D G$, Jankovic $L$, Plaseska $D$, Juricic $D$, Efremov GD: $A B^{\circ}$-thalassaemia due to a 1605 bp deletion of the $5^{1} \beta$-globin gene region. ( $\mathrm{Br} \mathrm{J}$ Haematol, in press)

31. Codrington JF, Li H-W, Kutlar F, Gu L-H, Ramachandran M, Huisman THJ: Observations on the levels of $\mathrm{Hb}_{2} \mathrm{~A}_{2}$ in patients with different $B$-thalassemia mutations and a $\delta$ chain variant. Blood 76:1246, 1990 
32. Boehringer RR, Ryan TM, Palmiter RL, Brinster RL, Townes TM: Human $\gamma$ - to $\beta$-globin gene switching in transgenic mice. Genes Develop 4:380, 1990

33. Feingold EA, Forget BG: The breakpoint of a large deletion causing hereditary persistence of fetal hemoglobin occurs within an erythroid DNA domain remote from the $\beta$-globin gene cluster. Blood 61:1273, 1989

34. Anagnou NP, Perez-Stable C, Gelinas R, Constantini F, Liapaki K, Constantopolou M, Costeas T, Moschonas N, Stamatoyannopoulos G: Sequences located $3^{\prime}$ to the breakpoint of HPFH-3 can modify the developmental expression of the A $\mathrm{A}_{\mathrm{g}} \mathrm{globin}$ gene. Cl in Res 38:301A, 1990

35. Dillon N, Grosveld F: Human B-globin genes silenced independently of other genes in the $\beta$-globin locus. Nature $350: 252,1991$

36. Tuan D, Solomon $W, L i Q$, London IM: The "B-like-globin" gene domain in human erythroid cells. Proc Natl Acad Sci USA 82:6384, 1985

37. Hanscombe 0 , Whyatt D, Fraser P, Yannoutsos N, Greaves D, Grosveld F: Importance of globin gene order for correct developmental expression. Genes Develop 5:1387, 1991

38. Beris Ph, Kitundu MN, Baysal E, Oner C, Lanclos KD, Dimovski AJ, Kutlar F, Huisman THJ: Black B-thalassemia homozygotes with specific sequence variations in the $5^{\prime}$ hypersensitive site-2 of the locus control region have high levels of fetal hemoglobin. Am J Hematol 41:97, 1992

39. Curuk MA, Dimovski AJ, Baysal E, Gu L-H, Kutlar F, Molchanova TP, Webber BB, Altay 6, Gurgey A, Huisman THJ: Hb Adana or a 259(E8)Giy->AspB 2, a severely unstable al-globin variant, observed in combination with the - (a) $20.5 \mathrm{~kb}$ a-thal-1 deletion in two Turkish patients. (Am $\mathrm{J}$ Hematol, in press)

40. Gilman JG, Huisman THJ: DNA sequence variation associated with elevated fetal $G$ g globin production. Blood $66: 783,1985$

41. Caterina JJ, Ryan TM, Pawlik KM, Palmiter RD, Brinster RL, Boehringer RR, Townes TM: Human $\beta-g l o b i n$ locus control region: Analys is of the $5^{\prime}$ DNase I hypersensitivity site-2 in transgenic mice. Proc Natl Acad Sci USA 88:1626, 1991

42. Gilman JG: Putative repressor proteins from human and mouse cells binds between GATA-1 and CACCC sites of human $y$ globin promoter. Blood 80:3a, 1992 (abstr)

43. Gilman JG, Brinson EC, Mishima $N$ : The $32.6 \mathrm{~kb}$ Indian $\delta \beta$-thalassaemia ends in a $3.4 \mathrm{~kb}$ Ll element downstream of the $B$ globin gene. $\mathrm{Br} \mathrm{J}$ Haematol 82:417, 1992 

CHAPTER 4d

POL MORPHIC PATTERN OF THE (AT) $X(T) Y$ MOTIF AT -530 5' TO THE $\beta$-GLOBIN GENE IN OVER 40 PATIENTS HOMOZYGOUS FOR VARIOUS G-THALASSEMIA MUTATIONS

\author{
A.J. Dimovski, A.D. Adekile, V. Divoky, E. Baysal, and T.H.J. Hui sman \\ Department of Biochemistry and Molecular Biology \\ Medical College of Georgia, Augusta, GA 30912-2100, USA
}

[Adapted from: Am. J. Hematol., in press (1993)]

\begin{abstract}
Nt sequence analysis of the $5^{\prime} B-g l o b i n$ gene flanking region has been carried out for numerous homozygous B-thal patients with different mutations and of various ethnic backgrounds. The (AT) $X(T) Y$ repeat motif at -530 showed polymorphic patterns among these patients as follows: A11 10 IVS-II-1 (G+A) chromosomes and the two with the $-87(C+G)$ mutation are associated with the $(A T)_{g}(T)_{5}$ rearrangement, while the 30 IVS-I-6 $(T * C)$, the $16 \mathrm{CD} 39(C+T)$, the six $C D 8$ (-AA) chromosomes, and 12 chromosomes with different promoter mutations had the $(A T)_{7}(T)_{7}$ motif. Six chromosomes with the promoter mutation at position $-29(A \rightarrow 6)$ had the $(A T)_{8}(T)_{6}$ motif, while an $(A T)_{8}(T)_{4}$ motif appears characteristic for two IVS-I-5 $6+A$ and 6H). No direct association between any of the $(A T)_{X}(T)_{Y}$ arrangements and an increased $\gamma$ gene expression ( $G$ and $H b F$ ) levefs could be demonstrated, suggesting that variations in the $(A T)_{X}(T)_{Y}$ motif are common polymorphisms.
\end{abstract}




\section{IRTRODUCTIOH}

There have been several suggestions that the negative regulatory sequences, especially those between $n t s-610$ and -490 in the $5^{\prime} \beta$-globin gene flanking region modulate $\mathrm{Hb} F$ expression and clinical severity among $\beta$-thal and SS patients (1-4). This region spans the binding site for the BP1 nuclear protein which is believed to be a negative regulatory transacting factor $(5,6)$.

of particular interest is the tandem repeat motif, (AT) $X(T) y$, which has a definite haplotype-linked polymorphic pattern among $\beta^{S}$ chromosomes (3). It has been postulated that the $(A T)_{9}(T)_{5}$ motif is associated with a stronger binding of the BP1 protein than is seen with the more common $(A T)_{7}(T)_{7}$ motif. The former is found in the ${ }_{B} S$ Indian haplotype (3) and has also been described in several individuals with "silent $\beta$-thal) $(1,2)$. Ragusa et al (4) have suggested that in patients with $\beta^{\circ}$-thal this motif interacts with the $C_{-} T$ mutation at $-158 G_{\gamma}$ to generate high levels of $H b F$. on the other hand, Wong et al (7) proposed that the $(A T)_{g}(T)_{5}$ motif is a common polymorphism found even in normal adults, and is not necessarily associated with silent $\beta$-thal.

We have sequenced the $\beta-g l o b i n$ gene $5^{\prime}$ flanking region in several patients with different $\beta$-thal mutations and of different ethnic backgrounds. Several aspects of the hematology and DNA sequence variations in many of these patients have been previously reported from our laboratory (8-11). In the present study an attempt was made to correlate $\gamma$ gene expression ( $G_{Y}$ and $H b F$ levels) with the $(A T)_{X}(T)_{Y}$ motif.

\section{MATERIALS AND METHODS}

B-Thal Homozygotes. Fifteen $\beta^{+}$IVS-I-6 $(T+C)$, one $\beta^{+}$IVS-I- 6 compound heterozygote for the $\mathbf{G}+\mathbf{T}$ and $\mathbf{G} \rightarrow \mathbf{A}$ substitutions, five $B^{\circ}$ IVS-II-1 $(\mathbf{G}+\mathbf{A})$, eight $B^{\circ} C D 39(C+T)$, and three $\beta^{\circ} C D 8(-A A)$ patients were studied. All patients had a mild phenotype, except seven of the eight CD 39 patients who were transfusion-dependent. Their countries of origin were Turkey, Macedonia, Italy, Hungary, and Portugal. Al so included were three Turkish patients with a homozygosity for promoter mutations characteristic of the Mediterranean region [one each of $-28(A+C),-30(T+A)$, and $-87(C+6)$ ], and seven American Black patients with promoter mutations [four -29 $(A+6)$ and three $-88(C \rightarrow T)]$. None of these 10 patients were transfusion-dependent.

Family Studies. Data on two illustrative families with members having a homozygosity or heterozygosity for the $-88\left(C_{-} T\right)$ mutation, but with different $(A T)_{X}(T)_{Y}$ motifs and varying levels of $G_{Y}$ and $H b F$, are included.

Normal Individuals. Data on the $(A T)_{X}(T)_{Y}$ motif in some Czechoslovakian individuals with normal hematology and no clinical problems are presented. Complete sequencing of the B-globin gene and gene mapping of the whole $\boldsymbol{B}$ cluster was carried out in all these individuals and there were not detectable variations. 
Blood samples were collected in vacutainers with EDTA as anticoagulant in the various centers and shipped to Augusta, GA. In some cases, DNA was isolated in the local centers before shipping. Transportation was by fast overnight air mail or by courier service.

Hematological data were obtained with automated cell counters. The $\mathrm{Hb} F$ and $\mathrm{Hb} A$ were quantified by cation exchange $\operatorname{HPLC}(12,13)$. The relative quantities of the $G_{\gamma}$ and $A_{\gamma}$ chains were determined by reversed phase HPLC $(14,15)$; when necessary, Hb F was isolated from the blood samples by DEAE-cellulose chromatography (16) prior to the reversed phase HPLC analysis.

DNA was isolated by the method of Poncz et al (17). Sequencing analysis of PCR-amplified DNA was with the dideoxy method of Sanger et a1 (18). The amplification and sequencing primers used for the $5^{\prime}$ flanking region of the $\beta$-globin gene are as follows:

Amplification primers 5'-TCCCCAGTTAACCTCCTATT-3' (forward), positions

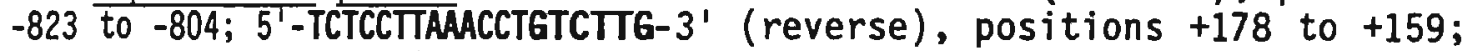
sequencing primers: $5^{\prime}$-TAAGAGGTCTCTAGTIIITATCTC- 3 ', positions -724 to $-700 ; 5^{\prime}$-AGATGGATGAAACTCTACCTC- $3^{\prime}$, positions -446 to $-468 ; 5^{\prime}$-AGAGATCCA TCTACATATCC- $3^{\prime}$, positions -418 to -400 .

All patients were screened for the most common a-thal-2 determinants (the $-3.7 \mathrm{~kb}$ and $-4.2 \mathrm{~kb}$ deletions) with a PCR-based methodology using specific oligonucleotides adjacent to the $5^{\prime}$ and $3^{\prime}$ breakpoints of each deletion. Details of this procedures are being reported separately (19).

\section{RESULTS}

Homozygous $\beta$-Thal Patients. ${ }^{G} Y$ and Hb F levels. Among the IVS-I-6 $(T+C)$ patients, nine were homozygous for haplotype $V I$ and were $A \gamma T$ positive, three were homozygous for haplotype VII, while the haplotype was not determined in the two Hungarian and one Portuguese patients. The footnote of Table 4d/1 lists the restriction sites used in haplotyping $(8,20)$. The $H b F$ levels in these 15 patients were between 3 and $35 \%$, and the $G_{\gamma}$ values between 45 and $74.5 \%$. Al1 but one were negative for the $X m n$ I site. The IVS-I-5 (G+T; $G * A)$ patient had a $H b F$ level of $98.7 \%$ and $G Y$ of $72.1 \%$, and was Xmn I positive $(+/+)$. The five IVS-II-1 $(G * A)$ patients al so had high $H b F$ and $G \gamma$ levels and all were Xmn I positive $(+/+)$. Hb $F$ levels were not obtained for the seven transfusion-dependent CD 39 patients, while the one milder affected subject had high $H b F$ and $G_{\gamma}$ values and was an Xmn I heterozygote. Two of the three CD 8 (-AA) patients had Hb $F$ levels of 98.6 and $98.4 \%$, respectively, while the third had recently been transfused because of an on-going bacterial infection. The $G_{Y}$ values in these three patients ranged from 72.4 to $73.6 \%$ and all were Xmn I homozygotes. The nine patients with a homozygous $B^{\circ}$-thal and a $\mathrm{Hb} F$ level in excess of $97 \%$ had total $\mathrm{Hb} F$ values varying between 4.2 and $11.9 \mathrm{~g} / \mathrm{dl}$ (average $8 \mathrm{~g} / \mathrm{dl}$; individual values are listed in Table $4 \mathrm{~d} / 1$ ). This greatly increased synthesis of $\mathrm{Hb} F$ was sufficient to make these patients transfusiondependent. 
TABLE 4d/1. Summary of Hematological and Genetic Data for B-Thal Homozygotes

\begin{tabular}{|c|c|c|c|c|c|c|c|c|c|c|c|c|}
\hline $\begin{array}{l}\text { Mutation } \\
\text { (Haplotype)a }\end{array}$ & $\begin{array}{l}\text { Patient } \\
\text { (Country)b }\end{array}$ & $\begin{array}{l}\text { Sex- } \\
\text { Age }\end{array}$ & $\begin{array}{c}\mathrm{Hb} \\
\mathrm{g} / \mathrm{dl}\end{array}$ & $\underset{\%}{H b ~ F}$ & $\begin{array}{l}\mathrm{Hb} F \\
\mathrm{~g} / \mathrm{dl}\end{array}$ & ${ }_{\%}^{\mathrm{Hb}} \mathrm{A}_{2}$ & $\underset{\%}{G_{\gamma}}$ & ${ }_{\mathscr{\%}}^{A}{ }^{\top}$ & $\underset{-158}{x m n} \stackrel{I}{G}$ & $\begin{array}{l}\text { No. of } \\
\text { a Genes }\end{array}$ & $\begin{array}{l}\text { (AT) } \\
X / Y\end{array}$ & $\begin{array}{l}T) Y \\
X / Y\end{array}$ \\
\hline \multirow[t]{9}{*}{ IVS-I-6 (VI/VI) } & MS (P) & $F-23$ & 7.7 & 23.2 & 1.8 & 4.2 & 60.1 & 39.9 & $-1-$ & 4 & $7 / 7$ & $7 / 7$ \\
\hline & MH (P) & $F-31$ & 8.5 & 3.0 & 0.3 & 7.3 & 55.1 & 44.9 & $-1-$ & n.d. & $7 / 7$ & $7 / 7$ \\
\hline & $R-94(M)$ & $F-32$ & 11.3 & 6.3 & 0.7 & 5.4 & 47.4 & 52.6 & $-1-$ & 4 & $7 / 7$ & $7 / 7$ \\
\hline & $R-95$ (M) & $M-30$ & 10.9 & 8.4 & 0.9 & 6.6 & 61.0 & 39.0 & $-1-$ & 4 & $7 / 7$ & $7 / 7$ \\
\hline & $P-5$ (M) & $M-28$ & 10.2 & 8.5 & 0.9 & 3.0 & 52.0 & 48.0 & $-1-$ & 4 & $7 / 7$ & $7 / 7$ \\
\hline & $4013(\mathrm{~T})$ & $M-13$ & 6.8 & 8.0 & 0.5 & 5.2 & 56.9 & 43.1 & $-1-$ & 4 & $7 / 7$ & $7 / 7$ \\
\hline & $4019(T)$ & $M-10$ & 5.4 & 7.0 & 0.4 & 6.8 & 54.8 & 45.2 & $-1-$ & 4 & $7 / 7$ & $7 / 7$ \\
\hline & $4025(T)$ & $M-16$ & 6.2 & 7.0 & 0.4 & 6.0 & 54.8 & 45.2 & $-1-$ & 4 & $7 / 7$ & $7 / 7$ \\
\hline & $4026(T)$ & $F-10$ & 7.0 & 10.4 & 0.7 & 4.0 & 56.6 & 43.4 & $-1-$ & 4 & $7 / 7$ & $7 / 7$ \\
\hline \multirow[t]{3}{*}{ IVS-I-6 (VII/VII) } & P-01 (M) & $F-38$ & 9.1 & 15.0 & 1.4 & 6.6 & 45.0 & 0 & $-1-$ & 4 & $7 / 7$ & $7 / 7$ \\
\hline & $P-01 B(M)$ & & 9.6 & 35.0 & 3.4 & 4.7 & 52.0 & 0 & $-1-$ & 4 & $7 / 7$ & $7 / 7$ \\
\hline & $0 . F .(T)$ & $M-10$ & - & 7.9 & - & 5.0 & 51.6 & 0 & $-1-$ & 4 & $7 / 7$ & $7 / 7$ \\
\hline IVS-I-6 (n.d.) & P.S. (P) & $F-37$ & 8.4 & 23.1 & 1.9 & 4.6 & 74.5 & 0 & $+/ t$ & 4 & $7 / 7$ & $7 / 7$ \\
\hline \multirow[t]{2}{*}{ IVS-I-6 (n.d.) } & $5412(H)$ & -16 & 6.9 & 28.4 & 1.9 & 4.7 & n.d. & n.d. & $-1-$ & 4 & $7 / 7$ & $7 / 7$ \\
\hline & $5413(H)$ & -15 & 9.2 & 17.9 & 1.6 & 5.4 & n.d. & n.d. & $-1-$ & 4 & $7 / 7$ & $7 / 7$ \\
\hline IVS-I-5 (n.d.) & C.M. $(T)$ & $M-17$ & 4.7 & 98.7 & 4.6 & 1.3 & 72.1 & 0 & +1 & 4 & $8 / 4$ & $8 / 4$ \\
\hline \multirow[t]{5}{*}{ IVS-II-1 (III/III) } & A.E. (T) & Adult & 12.2 & 97.7 & 11.9 & 2.3 & 74.3 & 0 & $+/ t$ & 3 & $9 / 5$ & $9 / 5$ \\
\hline & E.0. (T) & Adult & 6.2 & 98.6 & 6.1 & 2.3 & 72.2 & 0 & $+/ t$ & 4 & $9 / 5$ & $9 / 5$ \\
\hline & K. $(T)$ & Adult & 8.3 & 98.9 & 8.2 & 1.1 & 67.2 & 0 & $+/ t$ & 4 & $9 / 5$ & $9 / 5$ \\
\hline & M.K. (T) & Adult & 4.3 & 97.4 & 4.2 & 2.6 & 70.0 & 0 & $t / t$ & 4 & $9 / 5$ & $9 / 5$ \\
\hline & B.D. (T) & Adult & 8.7 & 98.6 & 8.6 & 1.4 & 71.2 & 0 & $t / t$ & 4 & $9 / 5$ & $9 / 5$ \\
\hline
\end{tabular}




\begin{tabular}{|c|c|c|c|c|c|c|c|c|c|c|c|c|}
\hline $\begin{array}{l}\text { Mutation } \\
\text { (Haplotype) }^{a}\end{array}$ & $\begin{array}{l}\text { Patient } \\
\text { (Country) b }\end{array}$ & $\begin{array}{l}\text { Sex- } \\
\text { Age }\end{array}$ & $\begin{array}{c}\mathrm{Hb} \\
\mathrm{g} / \mathrm{d} 1\end{array}$ & $\begin{array}{l}H_{6} \mathrm{~F} \\
\%\end{array}$ & $\begin{array}{l}\mathrm{Hb} F \\
\mathrm{~g} / \mathrm{dl}\end{array}$ & $\mathrm{Hb}_{\%}^{\mathrm{A}} \mathrm{A}_{2}$ & ${ }_{\%}^{G}$ & $\underset{\%}{A_{\gamma}^{\top}}$ & $\begin{array}{rl}X m n & I \\
-158 & G_{\gamma}\end{array}$ & $\begin{array}{l}\text { No. of } \\
\text { a Genes }\end{array}$ & $\begin{array}{l}\text { (AT) } \\
X / Y\end{array}$ & $\begin{array}{l}\text { (T) } Y \\
X / Y\end{array}$ \\
\hline \multirow[t]{8}{*}{ CD 39 (n.d.) } & $551(S)$ & Adult & 7. & \multicolumn{3}{|c|}{ Transfused } & 61.6 & 38.4 & n.d. & n.d. & $7 / 7$ & $7 / 7$ \\
\hline & $552(\mathrm{~S})$ & Adult & 9. & \multicolumn{3}{|c|}{ Transfused } & 58.2 & 18.2 & n.d. & n.d. & $7 / 7$ & $7 / 7$ \\
\hline & $573(S)$ & Adult & 8.3 & \multicolumn{3}{|c|}{ Transfused } & 49.8 & 15.8 & n.d. & n.d. & $7 / 7$ & $7 / 7$ \\
\hline & $583(S)$ & Adult & 7. & \multicolumn{3}{|c|}{ Transfused } & n.d. & n.d. & n.d. & n.d. & $7 / 7$ & $7 / 7$ \\
\hline & $586(\mathrm{~S})$ & Adult & 9.8 & \multicolumn{3}{|c|}{ Transfused } & 66.1 & 0 & n.d. & n.d. & $7 / 7$ & $7 / 7$ \\
\hline & $624(S)$ & Adult & 9.0 & \multicolumn{3}{|c|}{ Transfused } & n.d. & n.d. & n.d. & n.d. & $7 / 7$ & $7 / 7$ \\
\hline & $631(S)$ & Adult & 9.6 & \multicolumn{3}{|c|}{ Transfused } & 70.4 & 26.8 & n.d. & n.d. & $7 / 7$ & $7 / 7$ \\
\hline & II-2 (S) & Adult & 10.5 & 97.9 & 10.3 & 2.9 & 71.2 & 0 & $+/-$ & n.d. & $7 / 7$ & $7 / 7$ \\
\hline \multirow[t]{3}{*}{ CD 8 (IV/IV) } & D.C. (T) & F- 7 & 8. & 98.6 & 7.9 & 1.4 & 72.4 & 0 & $+/+$ & 4 & $7 / 7$ & $7 / 7$ \\
\hline & K.D. (T) & $F-16$ & 10. & 98.4 & 10.0 & 1.6 & 73.6 & 0 & $+/$ & & $7 / 7$ & $7 / 7$ \\
\hline & E.G. $(T)^{C}$ & F- 7 & 11.6 & 36.1 & 4.2 & 1.8 & 72.5 & 0 & $+/+$ & 4 & $7 / 7$ & $7 / 7$ \\
\hline-28 (n.d.) & H.B. (T) & Adult & 6.3 & 37.4 & 2.4 & 7.2 & 23.8 & 0 & $-1-$ & 4 & $7 / 7$ & $7 / 7$ \\
\hline \multirow{4}{*}{$\begin{aligned}-29 & (A / A) \\
& (A / B) \\
& (A / B) \\
& (A / A T)\end{aligned}$} & J.M. (A) & $F-44$ & 10.6 & 68.0 & 7.2 & 3.6 & 70.0 & 0 & $+/+$ & 3 & $8 / 6$ & $8 / 6$ \\
\hline & J.S. (A) & $M-23$ & 9.1 & 40.0 & 3.6 & 9.9 & 60.3 & 0 & $+/-$ & 4 & $8 / 6$ & $8 / 6$ \\
\hline & Jo.S. (A) & $F-27$ & 11.4 & 67.1 & 7.6 & 4.1 & 73.5 & 0 & $+/-$ & 3 & $7 / 7$ & $7 / 7$ \\
\hline & L.G. (A) & $F-26$ & 9.1 & 43.8 & 4.0 & 8.6 & 66.9 & 0 & $+/-$ & 4 & $8 / 6$ & $8 / 6$ \\
\hline-30 (n.d.) & S.S. (T) & Adult & 7.0 & 68.0 & 4.8 & 3.2 & 44.8 & 0 & $-1-$ & 4 & $7 / 7$ & $7 / 7$ \\
\hline$-87(V I I I / V I I I)$ & A. $3(\mathrm{~T})$ & $F-52$ & 9.9 & 31.2 & 3.1 & 7.7 & 77.3 & 0 & $+/+$ & 4 & $9 / 5$ & $9 / 5$ \\
\hline \multirow[t]{3}{*}{-88($$} & H.G. (A) & $M-80$ & 9.4 & 65.2 & 6.1 & 7.1 & 69.3 & 0 & $t / t$ & 4 & $7 / 7$ & $7 / 7$ \\
\hline & C.W. (A) & $F-24$ & 10.7 & 71.7 & 7.7 & 5.9 & 72.0 & 0 & $+/ t$ & 4 & $7 / 7$ & $7 / 7$ \\
\hline & T.M.F. (A) & $M-23$ & 11.0 & 56.6 & 6.2 & 5.9 & 34.2 & 0 & $-1-$ & 4 & $7 / 7$ & $7 / 7$ \\
\hline
\end{tabular}

a Haplotypes III, IV, VI, VII, and VIII according to Orkin et al (20); haplotypes A, A1, B, AY ${ }^{\top}$, and $Y$ according to Gonzalez-Redondo et al (8).

b $P=$ Portugal; $M=$ Macedonia; $T=$ Turkey; $H=$ Hungary; $A=$ America; $S=$ Sicily; $n . d .=$ not determined.

c Patient E.G. was transfused shortly before blood collection. 
One of the four patients with the $-29(A-G)$ promoter mutation was homozygous for haplotype $A(X \mathrm{mn} I ;+/+)$, while the other three were heterozygotes (one with $A / A_{Y}^{\top}$ and two with $A / B$ ). The Xmn I homozygote had a $G_{\boldsymbol{Y}}$ level of $70 \%$ and $H b F$ of $68 \%$; these values varied in the heterozygotes from 58.4 to $66.9 \%\left(G_{\gamma}\right.$ ) and from 40 to $49 \%$ ( $H b F$ ). Two of the three -88 $(C+T)$ patients were homozygous for haplotype $A_{1}$ (Xmn I positive) and their $G_{\gamma}$ values were 69.3 and $72 \%$, while the Hb F levels were 65.2 and $71.7 \%$, respectively. The third patient was homozygous for haplotype $Y$ (Xmn I negative) and had $a G_{\gamma}$ of $34.2 \%$ and $H b F$ of $56.6 \%$. The haplotypes were not determined in the two patients with either the $-28(A \rightarrow C)$ or the -30 $(T+A)$ promoter mutations. Both were $X m n I-/-$ and had $10 w G_{Y}$ values. The patient with the $-87(C+6)$ promoter mutation was homozygous for haplotype VIII and was $X m n ~ I+/+$ with a $G_{Y}$ level of $77.3 \%$ but with a $\mathrm{Hb} F$ level of only $31.2 \%$.

The $(A T) \times(T) y$ Motifs $5^{\prime}$ B-Globin Gene $(-542$ to -522$)$. The $(A T)_{7}(T)_{7}$ arrangement was found for the following chromosomes carrying different mutations as indicated: 30 with IVS-I-6 (T+C), irrespective of their haplotypes; 16 with CD $39(C+T)$; six with CD $8(-A A)$; two with $-28(A+C)$; two with $-29(A+6)$; two with $-30(T+A)$, and six with $-88(C+T)(T a b l e ~ 4 d / 2)$. The chromosome with the $-88(C+T)$ mutation also had a $C \rightarrow T$ substitution at position -543 as described for the ${ }_{B} S$ haplotype $\# 19(3)$. The two chromosomes carrying the IVS-I-5 mutation (either $\mathbf{G}+\mathrm{T}_{\text {or }} \mathrm{G}+\mathrm{A}$ ) had the $(\mathrm{AT})_{8}(\mathrm{~T})_{4}$ rearrangement with a $C+T$ substitution at position -543 . The six chromosomes carrying the $-29(A+6)$ mutation had the rare $(A T)_{8}(T)_{6}$ arrangement. The $(A T)_{9}(T)_{5}$ motif was found only for the ten chromosomes with the IVSII-1 (G+A) and for the two with the $-87(C+6)$ mutations. In all chromosomes studied only those with the $(A T)_{9}(T)_{5}$ motif showed the $T * C$ mutation at position -551 .

Sequences Between -302 to -294 and -275 to $-2635^{\prime}$ B-6lobin Gene. The other potential BP1 binding site between -302 and -294 and the $\mathrm{BP} 2$ binding site between -275 to -263 did not reveal any differences from the reference sequence in all the patients studied (data not shown).

a-Globin Gene Status. Only three individuals were found to have an $a-t h a 1-2$ trait $(-3.7 \mathrm{~kb})$ and the $-4.2 \mathrm{~kb}$ deletion was absent.

Family Studies (Fig. 4d/1). Details of the hematology and sequence variations in the ${ }^{6} \gamma$ and $A_{\gamma}$ promoters and in the LCR 5 'HS-2 sequence of Family B have been previously reported (21). The proband (I-2), a 40-yearold woman from the Cote d'Ivoire, is homozygous for the $B^{+}-88(C+T)$ mutation. She has had a mild clinical course, moderate microcytosis and hypochromia, and has maintained $a \mathrm{Hb}$ level of $12-15 \mathrm{~g} / \mathrm{dl}$. Her $\mathrm{Hb} F$ level has been about $80 \%$ with a $G_{Y}$ to $A_{\gamma}$ ratio of $58: 42$. Her husband is a hematologically normal Swiss citizen. Their daughters inherited the B-thal trait with mild microcytosis, hypochromia, and elevated Hb F levels; the oldest child (II-1) had $3 \% \mathrm{Hb} F$ with a low Gy value of $24.9 \%$, and the two other children had 12.5 and $12.9 \% \mathrm{Hb} \mathrm{F}$, with significantly higher $\mathrm{G}_{\gamma}$ values of 44 and $39.8 \%$, respectively. The $B$-globin promoter sequence analysis showed that I-2 is homozygous for the $(A T)_{8}(T)_{4}$ arrangement with a $C-T$ mutation at -543; she is also Xmn I negative $(-/-)$. The husband is heterozygous for 
TABLE 4d/2. DNA Sequences From -555 to -517 of the B-Globin Gene Promoter Among B-Thal Homozygotes

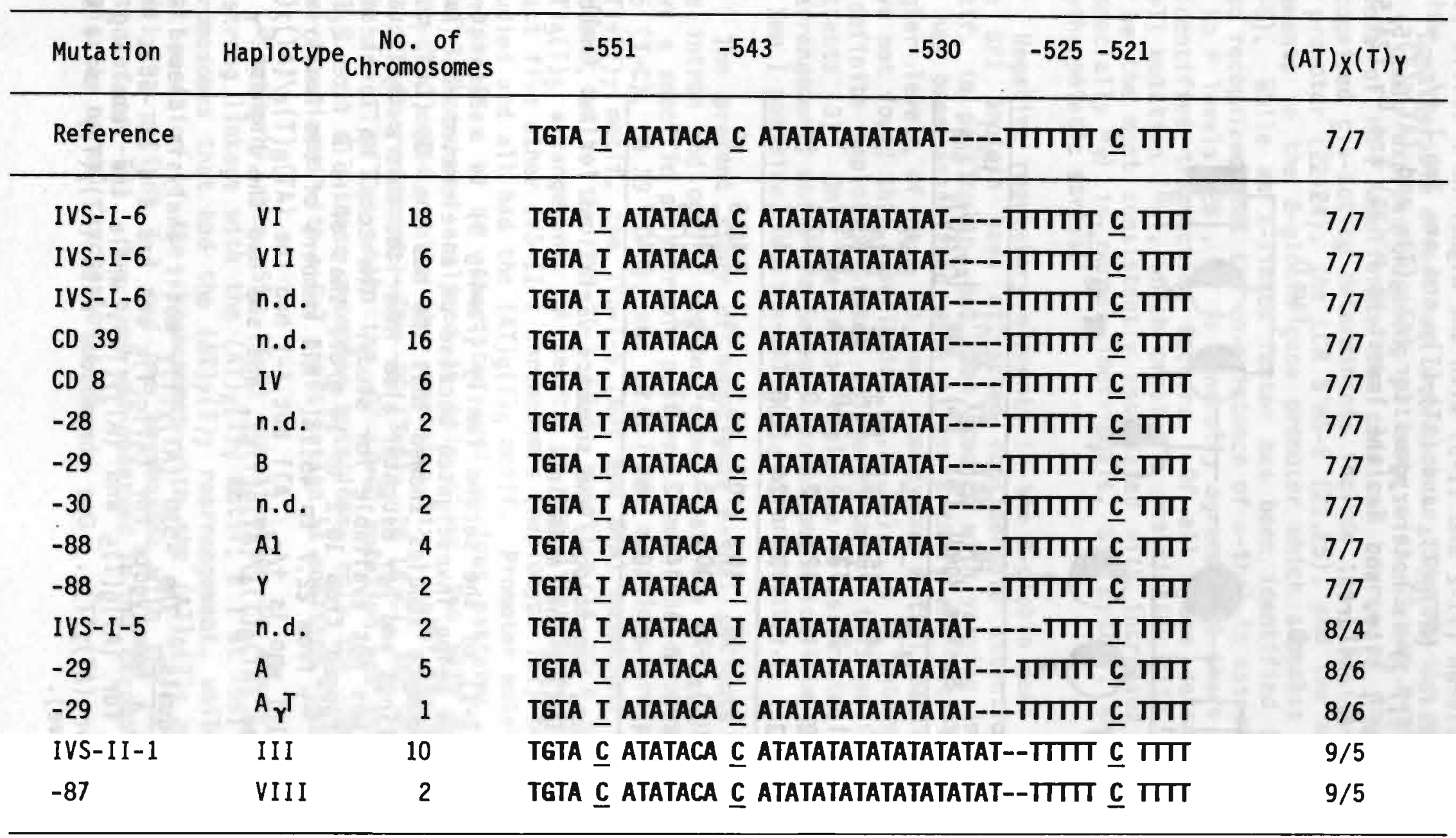


the $(A T)_{7}(T)_{7}$ and the $(A T)_{9}(T)_{5}$ patterns and is heterozygous for the $X m n I$ site $(+/-)$. Two children $(I I-2$ and II-3) with the higher Hb F levels (1213\% are heterozygous for $(A T)_{8}(T)_{4}$ and $(A T)_{7}(T)_{7}$ and are $X m n I+/-$, while the other daughter (II-1) is heterozygous for $(A T)_{8}(T)_{4}$ and (AT) $)_{9}(T)_{5}$, is negative for the $X m n I$ site, and has the lowest $H b F(3 \%)$ and $G_{Y}(24.5 \%)$ values among the three children.

Fam B.

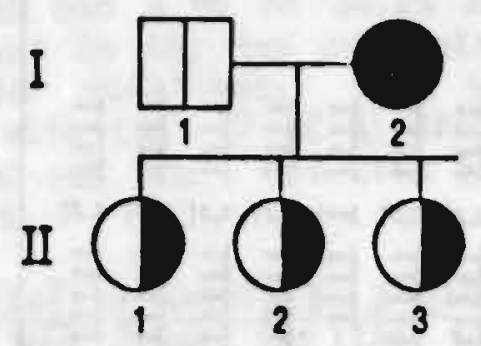

Fam D.

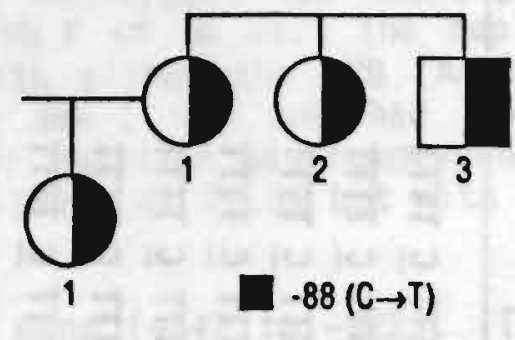

\begin{tabular}{|c|c|c|c|c|c|c|c|c|}
\hline & Subject & Sex/Age & $\begin{array}{c}H b \\
(g / d l)\end{array}$ & $\begin{array}{l}\mathrm{HbF} \\
(\%)\end{array}$ & $\begin{array}{c}G_{\gamma} \\
(\%)\end{array}$ & $\underset{\text { site }}{X m n ~ I}$ & $(\mathrm{AT})_{x}(\mathrm{~T})_{y}$ & $\begin{array}{l}\text { Rsa I } \\
\text { site }\end{array}$ \\
\hline \multirow[t]{5}{*}{ Fam B } & $1-1$ & $M-48$ & - & - & - & $+1-$ & $9.5 / 7.7$ & $+1-$ \\
\hline & $1-2$ & $F-40$ & 15.0 & 79.0 & 58.2 & $\%$ & $8.4 / 8.4$ & $\%$ \\
\hline & II-1 & $F-20$ & 12.7 & 3.0 & 24.9 & $\%$ & $8.4 / 9.5$ & $\%$ \\
\hline & II-2 & $F-18$ & 12.6 & 12.5 & 44.0 & $+1-$ & $8.4 / 7.7$ & $+1-$ \\
\hline & II-3 & F. 15 & 13.7 & 12.9 & 39.8 & $+1-$ & $8.4 \pi .7$ & +1 \\
\hline \multirow[t]{4}{*}{ Fam D } & 1.1 & $F-37$ & 10.9 & 10.7 & 45.1 & $+1-$ & $8.4 / 9.5$ & +1 \\
\hline & $1-2$ & $F-25$ & 10.2 & 5.2 & 27.7 & -1 & $8.4 / 7.7$ & $-1-$ \\
\hline & 1.3 & $M \cdot 33$ & 140 & 2.6 & 22.7 & $\%$ & $8.4 \pi .7$ & $\%$ \\
\hline & II-1 & $F-11$ & 10.7 & 9.4 & 39.1 & $\%$ & $8.4 \Pi 7.7$ & $+1-$ \\
\hline
\end{tabular}

FI6. 4d/1. Pedigrees, hematology, and sequence variations for two families with the $-88(C+T) B$-thal mutation.

The proband (I-1) of the second family (Family D) is a 37-year-old American Black woman being investigated because of an elevated $\mathrm{Hb} F$ level of $10-11 \%$. DNA sequence studies showed that she has the $-88(C+T)$ mutation. Her two siblings and her daughter also inherited this $\boldsymbol{B}$-thal trait, while her husband was not available for study. The total $\mathrm{Hb}$ level among these individuals ranged from 10.2 to $14 \mathrm{~g} / \mathrm{dl}$, that of $\mathrm{Hb} F$ from 2.6 to 10.7\%, and that of $G_{Y}$ from 22.7 to $45.1 \%$. All members of the family were Xmn I $-/-$, except I- 1 who is $+/-$. All but $I-1$ had the $(A T)_{8}(T)_{4} /(A T)_{7}(T)_{7}$ motifs; I-1 had the $\left.(A T)_{8}(T)_{4} /(A T)_{9}(T)_{5}\right)$, and she had the highest ${ }_{Y} r$ and $\mathrm{Hb} F$ levels.

Normal Individuals. The $-530(A T)_{X}(T)_{Y}$ motif analysis showed that one individual was a homozygote for $(A T)_{9}(T)_{5}$ and had a $C$ at -551 ; three were heterozygous for $(A T)_{9}(T)_{5}$ and $(A T)_{7}(T)_{7}$, while the remaining two were homozygous for $(A T)_{7}(T)_{7}$. One chromosome with $(A T)_{7}(T)_{7}$ had a $C$ at -551 (Rsa I positive). 


\section{DISCUSSION}

Considerable effort has been made to identify the genetic determinants of $\gamma$ chain expression among patients with SS and $B$-thal because higher levels of $\mathrm{Hb} \mathrm{F}$ ameliorate the clinical course of these diseases. The recognized cis-acting determinants include the $-158 \quad(C \rightarrow T)$ mutation in the $G_{y}$ promoter $(22-24)$, the LCR $5^{\prime} H S-2(21,25)$, and the negative regulatory elements in the B-globin gene promoter which suppress B chain synthesis $(3-6)$. While an $X-1$ inked factor has been identified $(26,27)$, and it is also recognized that the co-existence of $\alpha$-thal is associated with decreased Hb F levels (28), it is generally agreed that there are other, as yet, unidentified transacting factors. Of all these determinants, the -158 $(C+T)$ mutation $\left({ }^{G} \gamma\right)$, which creates a restriction site for $X m n$ I, appears to be the most consistently associated with increased $Y$ gene expression (especially $\mathrm{G}_{\mathrm{Y}}$ ) in normal individuals, SS, B-thal, and other states of erythropoietic stress.

Negative regulatory elements in the $\beta$-globin gene promoter that bind the BP1 protein have attracted considerable attention. The $(A T)_{g}(T)_{5}$ motif, in particular, has been studied with varying implications. While it has been associated with silent $B$-thal, and with mild phenotype and higher levels of $\mathrm{Hb} F$ in some homozygous $B$-thal patients (1-4), others have not found this association $(7,28,29)$. It is interesting to note that a definite haplotype-linked polymorphism of this motif exists among SS patients (3). Only the Indian haplotype is associated with the (AT) $)_{0}(T)_{5}$ rearrangement, while the Senegal haplotype, which like the Indian haplotype is Xmn I positive, has the $(A T)_{8}(T)_{4}$ arrangement.

The present study of homozygous $B$-thal patients with mutations in the intron and coding regions shows that the $(A T) X(T) y$ motif appears to have a specific polymorphic pattern. Thus, the chromosomes with the IVSI-6 $(T+C), C D 39(C \rightarrow T)$, and CD $8(-A A)$ mutations are associated with the $(A T)_{7}(T)_{7}$ motif, the IVS-I-5 ( $6+T$ and $\left.6+A\right)$ mutations with the $(A T)_{8}(T)_{4}$ pattern, while the IVS-II-1 (G+A) mutation is on a chromosome with the (AT) ${ }_{5}(T)_{5}$ arrangement. A search of the 1 terature $(2,4)$ shows that at least five other IVS-II-1 chromosomes (haplotype III) have been previously studied and all had the $(A T)_{9}(T)_{5}$ motif. Promoter mutations, on the other hand, appear to be associated with various patterns. Of the eight -29 $(A \rightarrow G)$ chromosomes analyzed in this study, two with haplotype B had the $(A T)_{7}(T)_{7}$ motif, while the remaining six (haplotypes $A$ and $A_{Y} T$ ) had the $(A T)_{8}(T)_{6}$ arrangement. The $-30(T \rightarrow A),-28(A+C)$, and $-88(C \rightarrow T)$ chromosomes all had $(A T)_{7}(T)_{7}$, while the $-87 \quad(C+6)$ mutation was associated with $(A T)_{9}$ $\left.(\mathrm{T})_{5}\right)$. Of all these promoter mutations, only the $-88 \quad(\mathrm{C}+\mathrm{T})$ chromosomes were associated with a $C+T$ substitution at position -543 (Table $4 d / 2$ ).

Similarly, the $-551(T+C)$ substitution in the $B$ promoter exhibited a strong linkage with the (AT) $\times(T)_{Y}$ motif; a $T$ at -551 was present in all chromosomes that had the $(A T)_{7}(T)_{7}$ rearrangement, while a $C$ was found at that position in the chromosomes with the $(A T)_{g}(T)_{5}$ motif. However, in Family $D$, patient I-1 had one chromosome with the $(A T)_{7}(T)_{7}$ arrangement with a $C$ at -551 . The same was observed in one chromosome from a hematologically normal Czechoslovakian. 
The fact that all homozygous $\beta$-thal patients with the $(A T)_{9}(T)_{5}$ motif were also Xmn I positive makes it difficult to assess the relative contributions of these two variations to any elevated $\boldsymbol{\gamma}$ chain expression that was observed. However, the IVS-II-1 and the CD 8 patients offer a unique opportunity for comparison. Both groups are Xmn I positive $(+/+)$ but the former have the $(A T)_{9}(T)_{5}$ motif, while the latter is associated with the $(A T)_{7}(T)_{7}$ arrangement. The $G_{Y}$ levels in both groups are similar with an average of 71 and $72.8 \%$, respectively. The same is true for the $H b F$ values, excluding the transfused CD 8 patient. Moreover, the three patients with other mutations who were homozygous for the $(A T)_{7}(T)_{7}$ motif and for the Xmn I site (P.S. with IVS-I-6, H.G. and C.W., both with the -88 promoter mutation) had high $G_{Y}$ and $H b F$ levels (Table $4 d / 1$ ). These comparisons indeed suggest that the Xmn I site is the more important contributory factor.

The two families presented in Fig. $4 \mathrm{~d} / 1$ also $i 11$ ustrate the relative contributions of the $(A T)_{X}(T)_{Y}$ motif and the $X m n I$ site to an enhanced $Y$ gene expression. In Family $B$, for instance, subject II-I is Xmn I negative and has the lowest values of $H b F$ and $G_{Y}$ among the three children (Hb F 3\%; GY 24.9\%) but is heterozygous for the (AT) $\left.)_{(T)}\right)_{5}$ motif. Furthermore, subject I-1 of Family D, whose chromosomes had similar (AT)X(T)Y motifs as seen in II- 1 of Family $B$, but is an Xmn I heterozygote $(+/-)$, has a considerably higher $\gamma$ gene expression ( $H b F 10.7 \% ; G_{Y} 45.1 \%$ ). These data would indicate that the $(A T)_{g}(T)_{5}$ motif by itself probably has no influence on $\gamma$ gene expression. Our finding of the (AT) ${ }_{9}(T)_{5}$ motif in normal individuals from Czechoslovakia, without an elevation in $\mathrm{Hb} F$ synthesis, also supports the view that it is not a rare polymorphism.

In conclusion, therefore, while the $(A T)_{X}(T) Y$ motif might indeed have a negative regulatory role on $\beta$-globin gene expression, as shown by in vitro binding studies (6), we have found no evidence that it plays an important regulatory role in $\gamma$ gene expression among the $\beta$-thal patients in this study. The $X m n$ I site at $-158^{\prime} 5^{\prime}$ to the ${ }^{G} \gamma$ globin gene shows a more positive association with $Y$ gene expression, but its presence does not account for all the variations in $G_{\gamma}$ and $H b F$ levels observed.

Acknowledgements. The authors are indebted to Drs. C. Altay and A. Gurgey (Turkey), Dr. G.D. Efremov (Macedonia), Drs. G.P. Tamagnini and M.L.S. Ribeiro (Portugal), Drs. G. Schiliro and B. Masala (Italy), and $\mathrm{Dr}$. Ph. Beris (Switzerland) for allowing us to study their patients. Mr. E.L.D. Walker, III assisted in the collection of blood samples from several patients. This study was supported by the United States Public Health Service research grant HLB-41544.

\section{REFERENCES}

1. Semenza GL, Delgrosso K, Poncz M, Malladi P, Schwartz E, Surrey S: The silent carrier allele: B Thalassemia without a mutation in the B-globin gene or its immediate flanking region. Cell 39:123, 1984. 
2. Murru S, Loudianos G, Cao A, Vaccargiu S, Pirastu M, Sciarratta GV, Agosti S, Parodi MI: A B-thalassemia carrier with normal sequence within the B globin gene. Blood 76:2164, 1990.

3. Elion J, Berg P, Lapoumeroulie C, Trabuchet G, Mittelman K, Krishnamoorthy $R$, Schechter AN, Labie D: DNA sequence variation in a negative control region $5^{\prime}$ to the $\beta$-globin gene correlates with the phenotypic expression of the ${ }_{B} S$ mutation. Blood 79:787, 1992.

4. Ragusa A, Lombardo M, Beldjord C, Ruberto C, Lombardo T, Elion J, Nagel RL, Krishnamoorthy R: Genetic epidemiology of B-thalassemia in Sicily: Do sequences $5^{\prime}$ to the $G_{Y}$ gene and $5^{\prime}$ to the $B$ gene interact to enhance Hb F expression in B-thalassemia? Am J Hematol 40:199, 1992.

5. Berg PE, Mittleman M, Elion J, Labie D, Schechter AN: Increased protein binding to a -530 mutation in the human B-globin gene associated with decreased $\beta-g l o b i n$ synthesis. Am J Hematol 36:42, 1991.

6. Berg PE, William DM, Qian R-L, Cohen RB, Cao S-X, Mittelman M, Schechter AN: A common protein binds to two silencers $5^{\prime}$ to the human B gene. Nucleic Acids Res 17:8833, 1989.

7. Wong SC, Stoming TA, Efremov GD, Huisman THJ: High frequencies of a rearrangement (+ATA; $-T$ ) at -530 to the $\beta-g l o b i n g e n e$ in different populations indicate the absence of a correlation with a silent B thalassemia determinant. Hemoglobin 13:1, 1989.

8. Gonzalez-Redondo JM, Stoming TA, Lanclos KD, GU Y-C, Kutlar A, Kutlar F, Nakatsuji T, Deng B, Han IS, McKie VC, Huisman THJ: Clinical and genetic heterogeneity in Black patients with homozygous $\beta$-thalassemia from the Southeastern United States. Blood 72:1007, 1988.

9. Diaz-Chico JC, Yang KG, Stoming TA, Efremov DG, Kutlar A, Kutlar F, Aksoy M, Altay 6 , Gurgey A, Kilinc Y, Huisman THJ: Mild and severe B-thalassemia among homozygotes from Turkey: Identification of the types by hybridization of amplified DNA with synthetic probes. Blood $71: 248,1988$.

10. Dimovski AJ, Efremov DG, Jankovic L, Juricic D, Zisovski N, Stojanovski N, Nikolov N, Petkov GT, Reese AL, Stoming TA, Efremov GD, Huisman THJ: B - Thalassemia in Yugoslavia. Hemoglobin 14:15, 1990.

11. Tamagnini GP, Goncalves P, Ribeiro MLS, Kaeda J, Kutlar F, Baysal E, Huisman THJ: $\beta$-Thalassemia mutations in the Portuguese; high frequencies of two alleles in restricted populations. Hemoglobin (in press).

12. Bisse $E$, Wieland H: High-performance liquid chromatographic separation of human haemoglobins - Simultaneous quantitation of foetal and glycated haemoglobins. J Chromatogr 434:95, 1988.

13. Kutlar A, Kutlar F, Gu L-G, Mayson SM, Huisman THJ: Fetal hemoglobin in normal adults and B-thalassemia heterozygotes. Hum Genet 85:106, 1990.

14. Shelton JB, Shelton JR, Schroeder WA: High performance liquid chromatographic separation of globin chains on a large-pore $C_{4}$ column. J Liq Chromatogr 7:1969, 1984.

15. Kutlar F, Kutlar A, Huisman THJ: Separation of normal and abnormal hemoglobin chains by reversed-phase high-performance liquid chromatography. J Chromatogr 357:147, 1986.

16. Schroeder WA, Huisman THJ: "The Chromatography of Hemoglobin." Clinical and Biochemical Analysis, Vol. 9, Marcel Dekker, Inc., New York, 1980. 
17. Poncz M, Solowiejczyk D, Harpel B, Mory Y, Schwartz E, Surrey E: Construction of human gene libraries from small amounts of peripheral blood: Analysis of B-like globin genes. Hemoglobin 6:27, 1982 .

18. Sanger $F$, Nicklen $S$, Coulson AR: DNA sequencing with chain terminating inhibitors. Proc Nat1 Acad Sci USA 74:5463, 1977.

19. Baysal $E$, Huisman THJ: Detection of common a-thalassemia-2 determinants by PCR. In preparation.

20. Orkin SH, Kazazian HH Jr, Antonarakis SE, Goff SC, Boehm CD, Sexton JP, Waber PG, Giardina PJV: Linkage of $B$-thalassaemia mutations and B-globin gene polymorphisms with DNA polymorphisms in human B-globin gene cluster. Nature 296:727, 1982.

21. Beris Ph, Kitundu MN, Baysal E, Oner C, Lanclos KD, Dimovski AJ, Kutlar F, Huisman THJ: Black B-thalassemia homozygotes with specific sequence variations in the $5^{\prime}$ hypersensitive site-2 of the locus control region have high levels of fetal hemoglobin. Am J Hematol 41:97, 1992.

22. Adekile $A D$, Huisman THJ: $H b F$ in sickle cell anemia. Experientia (in press).

23. Gilman JG, Huisman THJ: Two independent genetic factors in the B-globin gene cluster are associated with high $G_{Y}$ levels in the $H b F$ of B-thalassemia patients. Blood 64:452, 1984.

24. Labie $D$, Dunda-Belkhodja $O$, Rouabhi $F$, Pagnier $J$, Ragusa $A$, Nagel RL: The -158 site $5^{\prime}$ to the $G_{Y}$ gene and $G_{\gamma}$ expression. Blood $66: 1463$, 1985.

25. Oner C, Dimovski AJ, Altay 6, Gurgey A, Gu Y-C, Huisman THJ, Lanclos KD: Sequence variations in the $5^{\prime}$ hypersensitive site-2 of the locus control region of the ${ }_{B} S$ chromosomes are associated with different levels of fetal hemoglobin in Hemoglobin $S$ homozygotes. Blood 79: $813,1992$.

26. Miyoshi K, Kaneto $Y$, Kawai $H$, Ohchi H, Niki S, Hasegawa K, Shirakami A, Yamo T: X-linked dominant control of F-cells in normal adult life: Characterization of the Swiss type of hereditary persistence of fetal hemoglobin regulated dominantly by gene(s) on the $X$ chromosome. Blood 72:1854, 1988 .

27. Dover GJ, Smith KD, Chang YC, Purvis S, Mays A, Meyers DA, Sheils $C$, Serjeant GR: Fetal hemoglobin levels in sickle cell disease and normal individuals are partially controlled by an $X-1$ inked gene located at Xp22.2. Blood 80:816, 1992.

28. Galanello R, Gasperini D, Perseu L, Melis MA, Maccioni L: Heterozygous B-thalassemia with thalassemia intermedia phenotype. 8th Conference on Hemoglobin Switching. Abstract, 1992. 
CHAPTER 4e

\title{
THE IN VIYO EXPRESSION OF THE GLOBIN GENES OF THE B CISTRON IN $\gamma-, \delta-$, AND $\delta \theta-T H A L A S S E M I A$ HETEROZYEOTES
}

\author{
A.J. Dimovski, A.D. Adekile, and T.H.J. Huisman
}

Department of Biochemistry and Molecular Biology

Medical College of Georgia, Augusta, GA 30912-2100, USA

[Adapted from: Experientia, in press (1993)]

\section{ABSTRACT}

There is considerable evidence suggesting that the switch from $\gamma$ to $\delta$ and $\beta$ chain production after birth is due, in part, to silencing of the $Y$ genes by stagespecific factors which bind to their promoters and to the competition from the adult ( $\delta$ and $\beta$ ) genes for a common enhancer element located in the LCR. As a consequence one can expect that the increased $H b F$ production in adults with HPFH or $\delta \beta$-thal is directed mainly by $\gamma$-globin genes in cis to the deletion(s) responsible for these conditions. Here we review data on heterozygotes with $\gamma$-, $\delta$ - or $\delta \beta$-thal, who also had an $A_{\gamma}{ }^{\top}$ mutation, in cis or in trans, which was used as a marker of $\gamma$ gene expression. The results show that a deletion affecting adult $B$ genes favors the expression of $\gamma$ genes in cis, while the deletion of a single $\gamma$ gene does not affect the expression of the $B$ gene in cis but leads to a faster $\gamma->B$ switch postnatally. 


\section{INTRODUCTIOH}

The human B-like globin genes are located on the short arm of chromosome 11 and are arranged in a cluster as shown in Fig. 4e/1. Two switches are observed in the expression of these genes during human development; $\varepsilon->\gamma$ in the embryonic to fetal period and $\gamma->B$ postnatally. This $H b$ switching is believed to be directed by the LCR sequences $5^{\prime}$ to the $\varepsilon$ gene. Different suggestions have been made to explain the modulating factors of this process; one involves the competition of the adult and fetal globin genes for interaction with the LCR which may be the major factor in suppressing the $\gamma$-globin genes, and another involves the silencing of these genes by stage-specific negative factors which bind to their promoters. These processes may depend on the position of the particular gene in the $B$ cistron and on the presence of other active genes between it and the LCR $(1-3)$. This would suggest that the increased Hb $F$ production in HPFH and $\delta B$-thal heterozygotes with well-defined deletions would be directed by the $\gamma$-globin genes in cis to the deletion, while $B$ chain production is not affected in adults with deletional $\gamma$ - or $\delta$-thal.

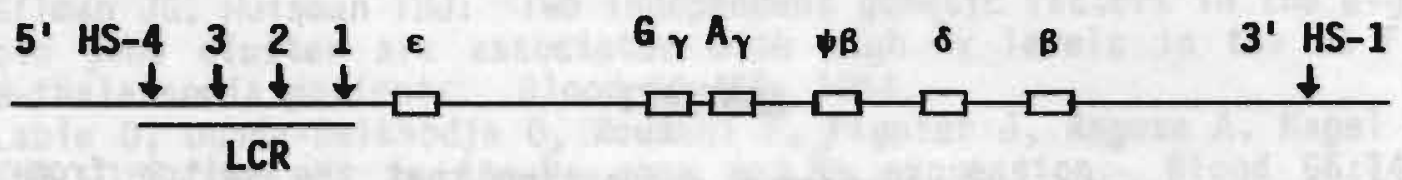

FI6. 4e/1. Arrangements of the human B-like globin genes on chromosome 11 .

Here we review data on patients with a heterozygosity for $\gamma-, \delta$ - or $\delta \beta$ - thal who had the $A_{\gamma} T$ mutation [i.e. $\gamma 75(E 19)$ Ile->Thr in $A_{\gamma}$ (4)] in cis or in trans so that the relative contribution by the pair of $\gamma$ genes on each chromosome could be evaluated. Also included are $G_{Y}\left(A_{Y} \delta B\right)$-thal heterozygotes because the deletion of $A_{Y}$ in cis allows the $A_{\gamma}$ level to be a measure of the contribution in trans. The listed information comes mainly from reports published during the past 20 years (references in Table $4 \mathrm{e} / 1$ ) and from some unpublished data.

$\mathrm{Hb} \mathrm{A}_{2}$ was quantified by microcolumn chromatography (5) or by cation exchange HPLC $(6,7)$, and Hb $F$ by alkali denaturation $(8)$ or by cation exchange HPLC $(6,7)$; the latter two procedures give comparable data in the $\mathrm{Hb} F$ ranges of $5-20 \%(7)$. The relative quantities of the $G_{\gamma}, A_{Y}$, and $A_{\gamma}{ }^{\top}$ chains were determined by reversed phase HPLC (9-11). Identification of the deletion was by gene mapping analyses as described before (12-16). The presence of the $A_{\gamma} T$ mutation was confirmed in many cases by dot-blot analysis involving hybridization of amplified DNA with 32 p-labeled specific probes (methodology in Ref. 17). The presence of the $A_{\gamma}^{\top}$ mutation in cis or in trans to a particular deletion was evaluated by lineage analyses from extensive family studies.

\section{$A_{\gamma}^{\top}$ Heterozygotes Without Deletion(s) in the B-Globin Gene Cluster}

In a recent survey (18), we reviewed over 1,000 newborn babies with $A A, A S, A C, S S, S C$, and $C C$, who all had about equal percentages of $A_{\boldsymbol{\gamma}}{ }^{\top}$ and $A_{\gamma}$ chains (52 and $48 \%$ of total $A_{\gamma}$, respectively). Our data for eight 
normal adults gave a slightly different ratio of $46: 54 \%$ ( $A_{\gamma} T_{:} A_{\gamma}$ ) which was similar to that seen in SS patients with haplotypes $17 / 19$ or $17 / 20$ or with haplotypes $17 / 3$ [haplotypes \#3, \#17, \#19, and \#20 refer to the Senegal, Cameroon, Benin, and CAR types; $B S$ chromosomes with haplotype "17 carry the $A_{K}{ }^{\prime}$ mutation (19)]. Thus, in all adults reviewed, a ratio of about $40\left(A_{Y}{ }^{\top}\right)$ to $60\left(A_{Y}\right)$ was observed, which is about the same ratio of abnormal $(X)$ to normal $\mathrm{Hb}$ chain $(A)$ as commonly found in heterozygotes for other abnormal Hbs ( $H b X$ ) (26). Our data on nine children with Fanconi's anemia with elevated $\mathrm{Hb} F$ levels averaging $7.1 \%$, who also has the $A_{\gamma}{ }^{\top}$ variant, showed a similar ratio (Table $4 \mathrm{e} / 1$ ).

\section{$A \gamma^{\top}$ Heterozygotes With Various $\delta \beta-T h a l$ Deletions}

Table $4 \mathrm{e} / 1$ also shows data on four types of deletional $\delta \beta$-thal, characteristics of which are in Fig. $4 \mathrm{e} / 2$. The average values are based on six or more cases except for three subjects with the Sicilian type of $\delta \beta$ thal. The $B$ lack $G_{\gamma}\left({ }^{A} \gamma \delta \beta\right)$-thal includes part of the $A_{\gamma}$-globin gene; thus, all $A_{\gamma}$ present in the $\mathrm{Hb} F$ of the 31 heterozygotes originates from the $A_{Y}$ gene in trans. The average $\mathrm{Hb} F$ level is $11 \%$ [19\% in the seven with $\mathrm{Hb} S-G_{\gamma}$ $(A, \overline{\delta \beta})-$ thal] and the contribution of the $G_{\gamma}$ gene in cis is about $90 \%$ (Fig. $4 \mathrm{e} / 2)$. No difference is seen between the subjects with the simple heterozygosity and those with the $H b S-G_{Y}\left(A_{Y} \delta_{B}\right)^{\circ}$-thal condition except for a higher level of $\mathrm{Hb} \mathrm{F}$ in the latter.

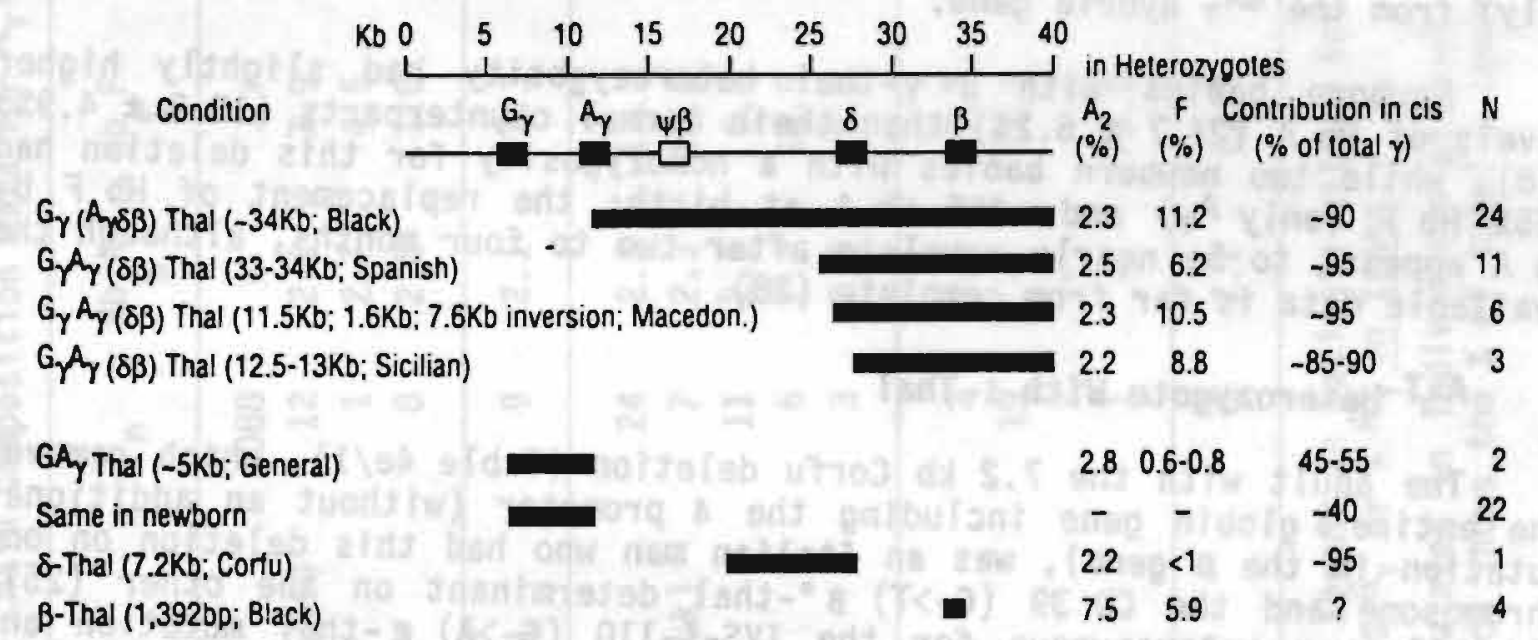

FI6. 4e/2. A comparison between the levels of $\mathrm{Hb} A_{2}$ and $\mathrm{Hb} F$ in adults with a heterozygosity for deletions of different globin genes of the B cistron, and the relative contribution of the $\gamma-g l o b i n$ genes in cis. See text for details.

The 11 Spanish and six Macedonian $\delta \beta$ thal heterozygotes have the $A_{\gamma} T$ mutation in cis to the deletion, and the high $A_{\gamma}^{\top}$ percentages (60 versus 3\% for $A_{Y}$ ) indicate that the decreased synthesis of $\mathrm{Hb} F$ is directed by the $r$ genes in cis. Consistent data were obtained for the three subjects with a heterozygosity for the Sicilian $\delta$ \&-thal who had a normal chromosome

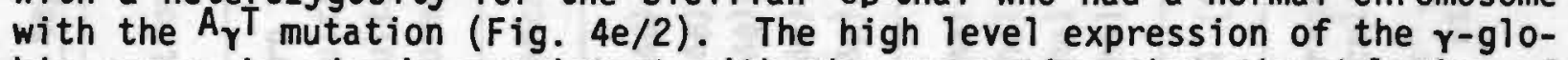
bin genes in cis is consistent with the suggestion that the deletion of the adult $\overline{B-}$ (and $\delta-$ ) globin gene promoter sequences prevents, in part, 
the silencing of the $\gamma$-globin genes in cis because the activation by the LCR sequences continues to be directed towards the remaining $\gamma$-globin genes. The possible differences in percentages of $\gamma$ chain contributed to the total Hb F levels by the genes in cis between the four types of $\delta \beta$-thal might be due to the presence of only one $\gamma$-globin gene in cis [the $G_{\gamma}\left({ }_{\gamma} \delta \beta\right)$-thal] and the presence (in the Sicilian $\delta \beta-t h a l$ ) or absence (in the Spanish and Macedonian $\delta \beta$-thal) of the $\delta$ promoter on the chromosome with the $\delta \beta$-thal deletion.

\section{$A_{\boldsymbol{\gamma}}{ }^{\top}$ Heterozygotes With $\boldsymbol{\gamma}$-Thal}

$\gamma$-Thal is a deletion of a DNA segment of $5 \mathrm{~kb}$ between the $G_{\gamma-\text { and }} A_{\gamma-}$ globin genes (27). The hybrid gene that results from the presumed crossover between $G_{Y}$ and $A_{Y}$ is indicated as a $G_{Y}$ because its protein product is identical to the $A_{Y}$ chain, while its $5^{\prime}$ end, including the promoter sequence, is the same as $G_{\gamma}$. As a result, its $A_{\gamma}$ chain is produced at a rate characteristic for the ${ }^{G} Y$ chain (reviewed in Ref. 18). The data listed in Table $4 \mathrm{e} / 1$ concern 22 newborn babies and two adults with a heterozygosity for this deletion. Nineteen babies did not carry the $A_{Y} T^{2}$ chain and had $60 \% A_{Y}$, two babies with $A_{\gamma}^{\top}$ in trans had $240 \% A_{Y}$ and $220 \% A_{Y}^{\top}$, and one baby with $A_{Y} T^{\text {in }}$ cis (the ${ }^{A}$ mutation is located within the $\mathrm{GA}_{Y}$ hybrid gene) had $20 \% A_{\gamma}$ and $240 \% A_{\gamma}$. The two adults with $A_{\gamma} T^{\top}$ in trans had $250 \% \gamma$ chain $\left(37 \% \mathrm{G}_{\gamma}\right.$ and $14 \% \mathrm{~A}_{\gamma}{ }^{\top}$ ) from genes in trans and $250 \%$ (A $\gamma$ only) from the $\mathrm{GA}_{Y}$ hybrid gene.

Newborn babies with a $\gamma$-thal heterozygosity had slightly higher levels of $\mathrm{Hb} \mathrm{A}(24.7 \pm 6.2 \%)$ than their normal counterparts $(18.9 \pm 4.9 \%)$ (18), while two newborn babies with a homozygosity for this deletion had 255\% $\mathrm{Hb} \mathrm{F}$ (only $A_{Y}$ ) and $245 \% \mathrm{Hb} \mathrm{A}$ at birth; the replacement of $\mathrm{Hb} F$ by $\mathrm{Hb}$ A appears to be nearly complete after two to four months, al though the available data is far from complete (28).

\section{A $\gamma^{\top}$ Heterozygote With $\delta$-Thal}

The adult with the $7.2 \mathrm{~kb}$ Corfu deletion (Table $4 \mathrm{e} / 1$ ), which removes the entire $\delta$ globin gene including the $\delta$ promoter (without an additional mutation in the $\boldsymbol{\beta}$ gene), was an Italian man who had this deletion on one chromosome and the CD 39 (C->T) $B^{\circ}$-thal determinant on the other (25). His wife was heterozygous for the IVS-I-110 (G->A) B-thal mutation and negative for $A_{\gamma} T$, while their son with a compound heterozygosity for both $B$-thal mutations, was heterozygous for $A_{\gamma}{ }^{\top}$. In the father the $H b F$ level was low $(<1 \%)$ with $A_{\gamma} T^{T}$ of $24 \%$ and $260 \% A_{\gamma}$, while the son had approximately equal amounts of $A_{Y} T^{T}$ and $A_{Y}(20 \%)$ in his $96 \%$ Hb $F$ at the age of about one year (Fig. $4 \mathrm{e} / 3$ ).

Although only this case of deletional $\delta$-thal was available, the result might suggest that loss of the $\delta$-globin gene promoter alone has a minimal effect on $Y$ chain synthesis which appears to be directed towards the $\gamma$ genes in cis while it has no effect on the $B$ gene expression. 
TABLE 4e/1. Hb $A_{2}$, Hb $F$, and $\gamma$ Chain Composition Data for $A_{\gamma}{ }^{\top}$ Heterozygotesa

\begin{tabular}{|c|c|c|c|c|c|c|c|c|}
\hline Condition & $\mathbf{n}$ & $\mathrm{Hb}_{\%}^{\mathrm{A}_{2}}$ & $\underset{\%}{H b} \mathrm{~F}$ & $\underset{\%}{G}$ & $\underset{\alpha}{A_{Y} T}$ & $\mathrm{~A}_{\mathbf{X}}$ & 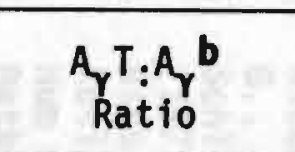 & Refs. \\
\hline Newborn & 1088 & - & - & 67.7 & 16.7 & 15.6 & $52: 48$ & 18 \\
\hline SS Adul ts (haplotypes $17 / 20 ; 17 / 19$ ) & 12 & 2.9 & 7.9 & 40.5 & 23.3 & 36.2 & $39: 61$ & 19 \\
\hline SS Adults (haplotypes $17 / 3$ ) & 1 & 2.7 & 4.5 & 60.0 & 18.2 & 21.8 & $45: 55$ & 19 \\
\hline AA (normal adults) & 8 & 2.6 & 1.0 & 39.4 & 27.9 & 32.7 & $46: 54$ & 20 \\
\hline AA (Fanconi's Anemia) & 9 & 2.1 & 7.3 & 40.4 & 25.1 & 34.5 & $42: 58$ & 21 \\
\hline 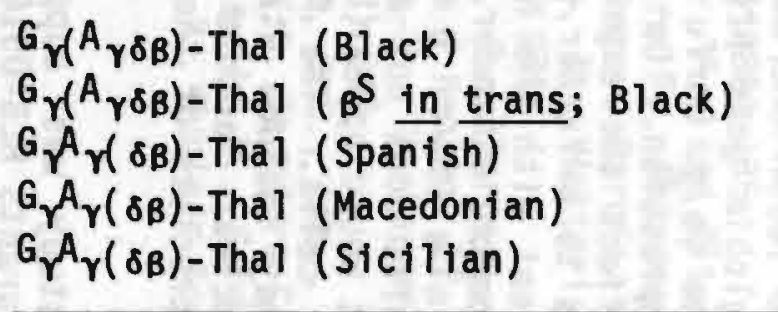 & $\begin{array}{r}24 \\
7 \\
11 \\
6 \\
3\end{array}$ & $\begin{array}{l}2.3 \\
2.3 \\
2.5 \\
2.3 \\
2.2\end{array}$ & $\begin{array}{r}11.2 \\
19.2 \\
6.2 \\
10.5 \\
8.8\end{array}$ & $\begin{array}{l}93.3 \\
93.1 \\
38.4 \\
40.1 \\
30.4\end{array}$ & $\begin{array}{r}0 \\
0 \\
58.7 \\
57.7 \\
9.4\end{array}$ & $\begin{array}{r}6.7 \\
6.9 \\
2.9 \\
2.2 \\
60.2\end{array}$ & 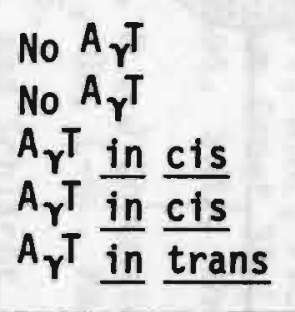 & $\begin{array}{l}14 \\
14 \\
22 \\
23 \\
21 ; 24\end{array}$ \\
\hline $\begin{array}{l}\mathrm{GA}_{\gamma} \text {-Thal (adults) } \\
\mathrm{GA}_{\boldsymbol{\gamma}} \text {-Thal (newborn) } \\
\mathrm{GA}_{\boldsymbol{\gamma}} \text {-Thal (newborn) } \\
\mathrm{GA}_{\boldsymbol{\gamma}} \text {-Thal (newborn) }\end{array}$ & $\begin{array}{r}2 \\
19 \\
2 \\
1\end{array}$ & $\begin{array}{l}2.8 \\
- \\
- \\
-\end{array}$ & $\begin{array}{c}0.7 \\
75.3 \\
- \\
76.9\end{array}$ & $\begin{array}{l}37.1 \\
40.7 \\
39.7 \\
42.6\end{array}$ & $\begin{array}{l}14.0 \\
0 \\
17.9 \\
38.8\end{array}$ & $\begin{array}{l}48.9 \\
59.9 \\
42.4 \\
18.6\end{array}$ & $\begin{array}{l}A_{\gamma^{\top}} \text { in trans } \\
N_{0} A_{\gamma^{\top}} \\
A_{\gamma}^{\top} \text { in trans } \\
{ }_{\gamma_{\gamma}^{\top}} \text { in } \underline{\text { in }}\end{array}$ & $\begin{array}{l}18 \\
18 \\
18 \\
18\end{array}$ \\
\hline -Thal (Corfu) & 1 & 2.2 & $<1.0$ & 33.9 & 4.1 & 62.0 & ${ }^{A} \gamma^{\top}$ in trans & 25 \\
\hline
\end{tabular}

average values only; ${ }^{A}{ }_{Y}{ }^{\top}$ was absent in patients with a few of the conditions; these are listed because calculations can be based on $\% G_{\gamma}$ or $\% A$ in trans.

b $A_{\gamma}{ }^{\top}: A_{\gamma}$ ratios were only calculated in individuals without deletions in the $\beta$-globin gene cluster; for the others, see Fig. $4 \mathrm{e} / 2$ which shows the $\%$ of total $\gamma$ contributed in $\underline{c}$ is to the deletions. 


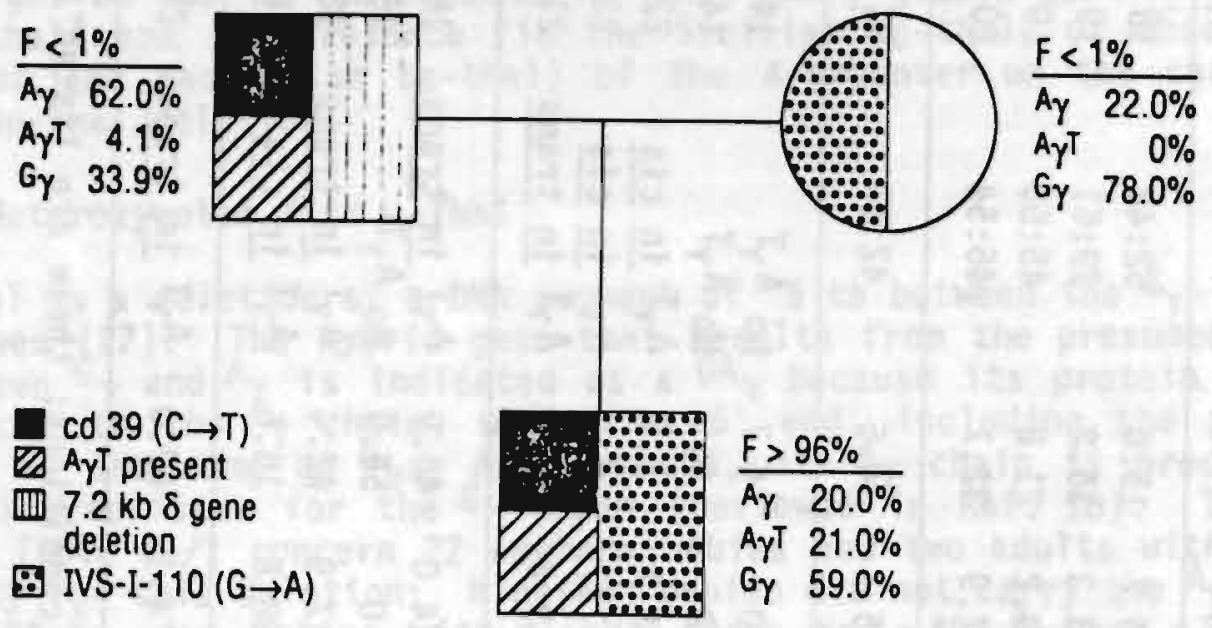

FIG. 4e/3. Pedigree of an Italian family where the father carries the $\$$
gene (Corfu) deletion on one chromosome and the $C D 39$-thal and $A$, gene (Corfu) deletion on one chromosome and the CD 39 B-thal and $A_{\gamma}$ tion.

\section{CONCLUSIONS}

The data in this report show that deletions affecting the adult globin genes $(\delta, \beta$, or both) appear to favor the expression of the fetal genes in cis, especially when the $\beta$-globin gene promoter is deleted. Deletion Timited to only the $\delta$-globin gene (e.g. Corfu $\delta$-thal) is associated with a minimal effect on the $\gamma$ gene expression. On the other hand, the deletion of a single $\gamma$ gene does not affect the expression of the $B$ gene in cis in adults; however, it may lead to a faster $\gamma->B$ switch in the postnatal period. These data are consistent with the hypothesis that $\gamma$ and $B$ genes compete for activation by a common enhancer element, presumably located in the LCR sequences. Since in $\beta$ and/or $\delta$ gene deletions the increased $\gamma$-globin gene expression in adults does not approach the level of $B$ chain produced by an intact $\beta$ gene, it would appear that the $B$ genes are actively silenced in adult hematopoietic cells. The factors involved in this process are not fully known but may include stage-specific regulatory (suppressors and/or activators) nuclear factors or factors involved in the organization of the chromatin structure of the $\beta-g l o b i n g e n e$ cluster.

Acknowledgements. This study was supported by the United States Public Health Service research grants HLB-05168 and HLB-41544. 


\section{REFERENCES}

1. Stamatoyannopoulos, G., Science 252 (1991) 383.

2. Dillon, N., and Grosveld, F., Nature 350 (1991) 252.

3. Hanscombe, 0., Whyatt, D., Fraser, P., Yannoutson, N., Greaves, D., Dillon, N., and Grosveld, F., Genes Devel 5 (1991) 1387.

4. Ricco, G., Mazza, U., Turi, R.M., Pich, P.G., Camaschella, C., Saglio, G., and Bernini, L.F., Hum Genet 32 (1976) 305.

5. Schleider, C.T.H., Mayson, S.M., and Huisman, T.H.J., Hemoglobin 1 (1977) 503.

6. Bisse, E., and Wieland, H., J Chromatogr 434 (1988) 95.

7. Kutlar, A., Kutlar, F., Gu, L-G., Mayson, S.M., and Huisman, T.H.J., Hum Genet 85 (1990) 106.

8. Betke, K., Marti, H.R., and Schlicht, I., Nature 184 (1959) 1877.

9. Huisman, T.H.J., and Wilson, J.B., Am J Hematol 9 (1980) 225.

10. Shelton, J.B., Shelton, J.R., and Schroeder, W.A., J Liq Chromatogr 7 (1984) 1969.

11. Kutlar, F., Kutlar, A., and Huisman, T.H.J., J Chromatogr 357 (1986) 147.

12. Kutlar, A., Gardiner, M.B., Headlee, M.G., Reese, A.L., Cleek, M.P., Nagle, S., Sukumaran, P.K., and Huisman, T.H.J., Biochem Genet 22 (1984) 21.

13. Diaz-Chico, J.C., Yang, K.G., Kutlar, A., Reese, A.L., Aksoy, M., and Huisman, T.H.J., Blood 70 (1987) 583.

14. Henthorn, P.S., Smithies, O., Nakatsuji, T., Felice, A.E., Gardiner, M.B., Reese, A.L., and Huisman, T.H.J., Br J Haematol 59 (1985) 343.

15. Padanilam, B.J., Felice, A.E., and Huisman, T.H.J., Blood 64 (1984) 941.

16. Gilman, J.G., Huisman, T.H.J., and Abels, J., Br J Haematol 56 (1984) 339.

17. Gonzalez-Redondo, J.M., Stoming, T.A., Lanclos, K.D., Gu, Y.C., Kutlar, A., Kutlar, F., Nakatsuji, T., Deng, B., Han, I.S., McKie, V.C., and Huisman, T.H.J., Blood 72 (1988) 1007.

18. Huisman, T.H.J., Kutlar, F., and Gu, L-H., Hemoglobin 15 (1991) 349.

19. Hattori, Y., Kutlar, F., Kutlar, A., McKie, V.C., and Huisman, T.H.J., Hemoglobin 10 (1986) 623.

20. Hattori, Y., Kutlar, F., Mosley, C.J., Mayson, S.M., and Huisman, T.H.J., Hemoglobin 10 (1986) 185.

21. Huisman, T.H.J., Kutlar, F., and Altay, C., unpublished data.

22. Huisman, T.H.J., Kutlar, F., Nakatsuji, T., Bruce-Tagoe, A., Kilins, Y., Cauchi, M.N., and Romero Garcia, C., Hum Genet 71 (1985) 127.

23. Efremov, G.D., Nikolov, N., Hattori, Y., Bakioglu, I., and Huisman, T.H.J., Blood 68 (1986) 971.

24. Efremov, G.D., Ibarra, B., Gurgey, A., Sukumaran, P.K., Altay, C., and Huisman, T.H.J., Am J Hematol 12 (1982) 367.

25. Ribeiro, M.L.S., Gu, L-H., Buchanan-Adair, I., and Huisman, T.H.J., Am J Hum Genet 52 (1993) 842.

26. Bunn, H.F., and Forget, B.G., Eds., Hemoglobin: Molecular, Genetic, and Clinical Aspects, W.B. Saunders Company, Philadelphia (USA) 1986.

27. Sukumaran, P.K., Nakatsuji, T., Gardiner, M.B., Reese, A.L., Gilman, J.G., and Huisman, T.H.J., Nucleic Acids Res 11 (1983) 4635. 
28. Huisman, T.H.J., Reese, A.L., Gardiner, M.B., Wilson, J.B., Lam, H., Reynolds, A., Nagle, S., Trowell, P., Zeng, Y.T., Huang, S.Z., Sukumaran, P.K., Miwa, S., Efremov, G.D., Petkov, G., Sciarratta, G.V., and Sansone, G., Am J Hematol 14 (1983) 133. 


\section{CHAPTER 5}

D I SCUSSION 


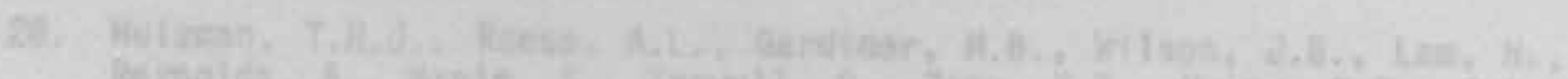

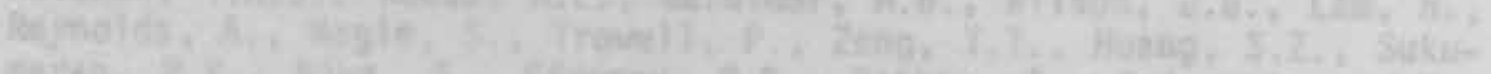

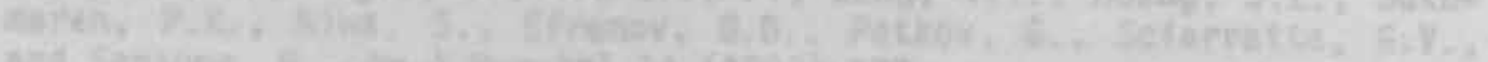

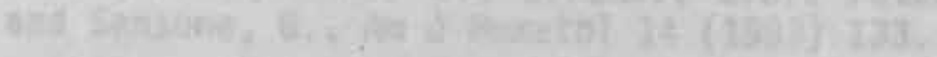

\section{E}




\section{CHAPTER 5}

\section{DISCUSSION}

The main objective of this study was an evaluation of the genetic factors linked to the $\beta$-globin gene cluster which could be responsible for the variable Hb $F$ levels in patients with SS and $B$-thal. The review of the older results for $\gamma-, \delta$, and $\delta \beta$-thal heterozygotes, summarized in Chapter $3 e$, provide convincing data to indicate that effect of mutations and/or deletions leading to an increase in $\boldsymbol{\gamma}$ chain production is primarily observed in cis to this variation. This observation is important when heterozygotes or compound heterozygotes are reviewed but not when the patient carries the same changes on both chromosomes.

The study of the SS patients included the evaluation of sequence differences in sequences of the two $\gamma$-globin genes (the $1.3 \mathrm{~kb}$ promoter region and the IVS-II region) and of the LCR $5^{\prime}$ HS-2, HS-3, and HS-4 core regions, among SS chromosomes associated with high (haplotypes \#31 and \#3) and low (haplotypes \#19, \#20, and \#17) $\gamma$ chain synthesis. A large segment $(1.3 \mathrm{~kb}$ ) of the $5^{\prime}$ flanking promoter region was chosen because of the potential role on gene expression; both positive (enhancer) and negative (silencer) regulatory elements upstream from the consensus promoter sequence have been described $(1,2)$. The IVS-II region was investigated because this major intron may have sequences that have enhancer activity (3) and is required for the regulation of expression by the LCR (4). The LCR $5^{\prime}$ HS-2, HS-3, and HS-4 sequences have also been analyzed because of the dominant role of these sequences in the regulation of the $\beta$-globin gene cluster expression $(5,6)$.

The results obtained have also been used for the establishment of a simple PCR based procedure to determine the five major ${ }_{B} S$ haplotypes. Using this procedure, it was possible to evaluate the association between the haplotype specific sequence variations and the hematological data in numerous samples from all over the world, and to determine the geographical distribution of various $B S$ chromosomes in Africa, Mediterranean countries, and India.

The studies of $B$-thal homozygotes included sequence analysis of the $G_{\gamma}$ and $A_{Y} 5^{\prime}$ flanking and LCR $5^{\prime}$ HS-2 regions in a group of patients with $\beta$ thal intermedia and markedly elevated levels of $\mathrm{Hb} F$. The polymorphic $(A T) X(T)_{Y}$ motif in the $5^{\prime} B-g l o b i n$ gene flanking region was determined in numerous homozygous $\beta$-thal patients with different mutations and various ethnic backgrounds because of reports indicating that this segment of DNA might decrease the activity of the B-globin gene. The mechanisms involved in the regulation of $\gamma$-globin gene expression in heterozygotes for various types of deletional $\gamma_{-}^{-}, \delta_{-}, B_{-}$, and $\delta \beta_{-}$thal have also been evaluated.

From the results obtained it is not possible to establish an association between a single determinant and the increase in $\mathrm{Hb} F$ levels in SS and B-thal patients. Extensive sequence and gene mapping analysis of the regulatory regions of various SS and B-thal chromosomes revealed numerous differences from the published sequences. Their functional importance was 
assessed mainly through an evaluation of a possible association of a single sequence variation (or a combination of several variations) with variations in the Hb F level in these patients. Particular attention was paid to changes in important nuclear protein binding sites that have previously been shown to be involved in the regulation of the globin gene expression $(7,8)$. Although in vitro expression studies have to be done to confirm the functional significance of certain variations observed in this study, nonetheless, several important observations can be highlighted:

1. Sequence Variations in the $G_{Y}$ and $A_{Y} 5^{\prime}$ Flanking Regions. Sequencing analysis of the $1.3 \mathrm{~kb}$ of the $G_{Y}$ and $A_{\gamma} 5^{\prime}$ flanking regions has revealed numerous differences among the five ${ }_{B} S$ chromosomes defined by haplotypes $\# 3$, \#31, \#17, \#19, and \#20. The results were compared to two previously published sequences of the $B$-globin gene cluster, referred to in the literature as chromosomes $A$ and $B(F i g .3 a / 1)(9,10)$.

Two general patterns correlating with high and low $\mathrm{Hb} F$ expression have been observed. The ${ }_{B} S$ chromosomes associated with high $H b$ F expression (haplotypes \#3 and \#31) are very similar to each other and to chromosome A. The only distinguishing variation in these high $\mathrm{Hb} F$ expressing chromosomes is the $C+T$ substitution at position $-1585^{\prime}$ to $G_{\gamma}$. The effect of this mutation on the $\gamma$-globin gene expression has been the subject of many reports. It has also been found in association with elevated $G_{Y}$ levels and high $\mathrm{Hb} F$ levels in numerous $B$-thal major patients of several ethnic groups. The elevation in $\mathrm{Hb} F$ levels depends on other factors such as erythropoietic stress because normal persons with a homozygosity for this change in the $G_{r}$ promoter have only a minimal increase in their Hb $F$ level (11-15). It has been proposed that this mutation has a permissive role on $y$ gene expression, requiring interaction of additional factors such as hemolytic stress, expanded erythropoiesis or other molecular determinants linked to the $\beta$ globin gene. The $G+T$ change, which is located between two nuclear protein binding sites in the minimal $\mathrm{G}_{\boldsymbol{\gamma}}$ promoter, GATA-1 $(-176$ to -171$)$ and CACCC $(-145$ to -140$)$ proteins, affects the binding of a putative repressor nuclear protein (16). Further characterization of the nature and the role of this repressor may explain the molecular mechanism underlying the effect of the mutation on altered $\gamma$ gene expression.

The ${ }_{B} S$ chromosomes associated with low Hb F levels (haplotypes \#19, \#20, and \#17) showed multiple differences in the $G_{\gamma}$ and $A_{\gamma} 5^{\prime}$ flanking regions, most of which can be explained by gene conversions between chromosomes $A$ and $B$ in the African population. Haplotype specific sequence variations were found in the $G_{\gamma}$ and in the $A_{\gamma} 5^{\prime}$ flanking regions of both $B S$ chromosomes with haplotypes \#19 and \#20 (Fig. 3a/1). A $B$ S chromosome with haplotype \#17 has none of these but carries a $T \rightarrow C$ mutation at $C D 75$ ( $A_{Y}$ ) leading to the synthesis of the $A_{\gamma} T^{T}$ chain (Ile $\rightarrow$ Thr). The association of these sequence variations with $\mathrm{Hb} F$ levels has been evaluated in a large number of SS patients from all over the world (Table $3 \mathrm{c} / 2$ ); in general, the data show that the Hb F levels in SS patients with a homozygosity for haplotypes \#17, \#19, and \#20 are low (below 10\%), although considerable variations have been observed. Since the chromosomes with both high and low $\gamma$ chain expression carry the same haplotype specific sequence variations, it may well be that these changes are not the primary cause of the low Hb F levels observed in these patients. 


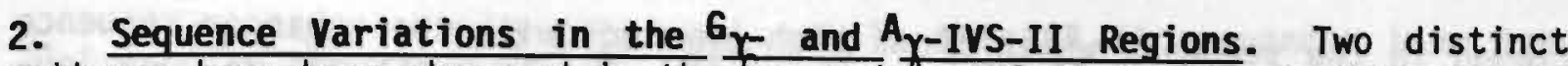

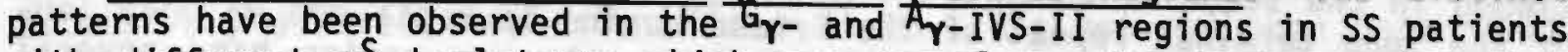
with different $B S$ haplotypes which may correlate with high and low $H b F$ expression. Chromosomes associated with a high $\gamma$ chain synthesis (haplotypes \#3 and \#31) are again similar to each other and to the sequence of chromosome $A$, whereas numerous differences, mainly located in the $A_{\gamma}$-IVS-II region, have been observed for chromosomes associated with low Hb $F$ levels (haplotypes \#19, \#20, and \#17) (Fig. 3a/2). Most of these differences can be the result of gene conversions between chromosomes $A$ and $B$ in the African population. A prime candidate for a possible relationship with altered $\gamma$ gene expression is the variation in the TG repeated sequence at position +1062 in the $A_{\gamma}$-IVS-II region, showing a (TG) 13 motif in the $B S$ chromosomes with haplotypes \#3 and \#31, and a variable polymorphic pattern for chromosomes with haplotypes \#17, \#19, and \#20. Ragusa et al (17) have recently shown that the same $A_{Y} T G$ motif in conjunction with the $G_{\gamma}-158(C+T)$ substitution is associated with high $\mathrm{Hb} F$ levels in $B$-thal patients from Sicily. Furthermore, a nuclear protein from K562 cells binds to this region to a different extent, the maximum binding being observed to the (TG) 13 motif.

3. Sequence Variations in the $(A T) \times(T) Y$ Motif $5^{\prime}$ to the $B-G l o b i n$ Gene Flanking Region. In order to evaluate the influence of this motif on the $\mathrm{Hb} F$ and ${ }^{\prime} Y$ levels, we have sequenced the $5^{\prime} B-g l o b i n$ gene flanking region in 42 homozygous $\beta$-thal patients with different $B$-thal mutations and of different ethnic backgrounds. The result showed that the motif has a specific polymorphic pattern associated with the particular chromosomal haplotype. Al1 chromosomes with the $(A T)_{9}(T)_{5}$ motif have the $G_{\gamma}-158(C+T)$ mutation which makes it difficult to assess the relative contribution of each of these two to the elevated Hb F levels. However, the results obtained for patients with a homozygosity for the frameshift at $C D 8(-A A)$ and for the IVS-II-1 (G*A) mutation offer a unique opportunity for comparison. Both groups have the $G_{\gamma}-158(C+T)$ mutation and comparable high levels of $\mathrm{Hb} F$, but the frameshift CD $8(-A A)$ mutation is associated with the $(A T)_{7}(T)_{7}$ motif, while the IVS-II-1 (G,A) change is on a chromosome with the (AT) $9(T)_{5}$ arrangement. The $(A T)_{7}(T)_{7}$ motif in association with the $\left.\mathrm{G}_{\mathrm{r}}-158 \quad \mathrm{C}_{\rightarrow} \mathrm{T}\right)$ mutation was also detected in several B-thal homozygotes with the IVS-II-6 $(T+C)$ and the $-88(C \rightarrow T)$ mutation, who also have elevated $H b F$ and $G_{\gamma}$ levels. This comparison indeed suggests that the $G_{Y}-158(C+T)$ mutation is the more important contributing factor to the overall $\gamma$ chain expression in $\beta$-thal.

4. Sequence Variations in the $5^{\prime}$ HS-2, HS-3, and HS-4. Sequence analysis of the core regions spanning the $5^{1} \mathrm{HS}-2, \mathrm{HS}-3$, and HS-4 have been performed for $S$ chromosomes with five different haplotypes. Three substitutions specific for haplotype $\# 19$ and a variable $(A T)_{X} n_{12}$ (AT) Y motif specific for each haplotype in $5^{\prime}$ HS-2 have been detected. No substitutions were present in the core sequences of $5^{\prime}$ HS-3, while a single nt substitution, which appears to be a common polymorphism, was present on both ${ }_{B} S$ chromosomes with haplotypes \#19 and \#3 in $5^{\prime}$ HS-4 LCR sequences.

The $\mathrm{nt}$ substitutions observed in $\mathrm{B}^{S}$ chromosomes with haplotype \#19 have been compared to the known protein binding sites in the LCR $5^{\prime}$ HS-2 (8). One of these, namely the $T+G$ substitution at position -10924 , is posi- 
tioned in the sequence which shows high homology with the enhancer sequence of the long terminal repeat of the Friend murine leukemia and Maloney leukemia viruses. Consensus sequences in this enhancer region bind several erythroid and ubiquitous transacting factors. The second substitution, $A+G$ at position -10905 , is within the CACCC motif and results in the sequence CCCCA $(+6)$ CCCCC that is a perfect canonical Spl nuclear protein binding site. CACCC-like sequences bind at least two ubiquitous transacting factors: Spl and TEF-2 (CACCC box protein or CBP). Recent experiments have shown that the CACCC sequence is necessary for full enhancer activity of the $5^{\prime}$ HS-2 element in in vitro expression studies (18). The third substitution, namely $A \rightarrow T$ at position -10390 , occurs in the $3^{\prime}$ segment of the 5' HS-2 and creates a GATTTC H4 TF-1 binding consensus site which is present in the promoter of the histone $\mathrm{H} 4$ gene, and is required for its full activity. The (AT) X $n_{12}$ (T) Y motif showed a specific pattern for each haplotype. The AT rich sequences are known to bind the repressor protein BP1 in the B-globin gene promoter region (19), while a homeobox HOX2H protein can also bind to this sequence $(20)$.

The functional significance of these findings have been supported by those in a Turkish SS patient with a homozygosity for haplotype \#19, who had unusually high $\mathrm{Hb} F$ (more than 20\%) and high $G_{y}$ levels (65\%), which is comparable to SS patients homozygous for haplotypes \#3 or \#31. However, sequence analysis of the $G_{\gamma} 5^{\prime}$ flanking and LCR $5^{\prime}$ HS-2 regions suggests that the patient has a hybrid ${ }_{B} S$ chromosome (named \#19A), resulting from a crossover that places sequences similar to the HS-2 of a $\beta^{S}$ chromosome with haplotype \#3 in juxtaposition to those of the $5^{\prime}$ flanking region of the $G_{\gamma-g l o b i n}$ gene of a $\beta^{S}$ chromosome with haplotype \#19. Adekile et al (21) have described two Nigerian SS patients having a different but comparable hybrid chromosome which was also associated with increased $\mathrm{Hb} F$ levels.

The analysis of sequence variations in the LCR $5^{\prime}$ HS-2 of a Black patient with a mild B-thal major, due to a homozygosity for the $-88 \quad(C \rightarrow T)$ mutation and with a high $H b F$ level, showed that the same sequence variations characteristic for haplotype \#19A were present; apparently these are associated with an increased $\boldsymbol{\gamma}$ chain production. Additional studies on relatives of the proband and on 10 unrelated $B$ lack $B$-thal homozygotes with either the $C \rightarrow T$ mutation at -88 or with the $A \rightarrow 6$ mutation at -29 , confirm the possible importance of the sequence differences in the $5^{\prime}$ HS-2, and also suggest that at least two additional factors, namely a $C \rightarrow T$ mutation at position -158 of the $\gamma$ promoter and a relative deficiency in a chain synthesis, play a role in the increased $\mathrm{Hb} F$ synthesis in these patients (Table $4 a / 3$ ).

The molecular mechanism responsible for the observed phenotypes is still unclear. However, it appears that the substitutions observed in the 5 ' HS-2 of chromosomes with haplotype \#19 do not allow for optimal interactions or transacting factors produced under hematopoietic stress in patients with SS or $\beta$-thal major, which are necessary for the reactivation of the $\gamma$ genes. Conversely, the relatively unaltered sequences in the $5^{\prime}$ HS-2 of chromosomes with haplotypes \#3 and \#31 may present a chromosomal structure which favors these interactions, thus allowing for a higher $H b \mathrm{~F}$ expression. 
5. 3' HS-1 and $\gamma$ Gene Silencing. While the LCR $5^{\prime}$ sequences have been extensively studied, the role of the $3^{\prime}$ HS- 1 has not yet been determined. Initially, it was suggested that the $3^{\prime} \mathrm{HS}-1$ determines the $3^{\prime}$ boundary of the $\beta$-globin gene cluster on chromosome 11 (22), but its contribution to the overall LCR activity has not been established. The two new deletional $B^{\circ}$-thalassemias discovered in this study give an opportunity for an evaluation of the possible function( $s)$ of these sequences.

The Croatian $1.6 \mathrm{~kb}$ deletion was detected in a $\beta$-thal heterozygote who presented with mild microcytosis and hypochromia with unusually high $\mathrm{Hb} \mathrm{A}_{2}$ (7.6\%) and moderately elevated $\mathrm{Hb} F(5.8 \%)$ levels. This deletion removes $985 \mathrm{bp}$ of the $5^{\prime}$ flanking region, the $5^{\prime}$ UTR, exons 1 and 2, IVS-I, and $125 \mathrm{bp}$ of the IVS-II of the B-globin gene. It appears that the absence of the $5^{\prime}$ promoter region allows for a stronger interaction of the remaining $\delta$ - and $\gamma$-globin genes with factors responsible for the activating effect of the $5^{\prime}$ LCR sequences. The preferential expression of $\delta$ - versus $\gamma-g$ lobin genes in cis to the deletion is probably due to the active silencing of the fetal genes in the adult erythropoietic tissues by either stage specific regulatory nuclear proteins or by the factors involved in the organization of the chromatic structure of the B-globin gene cluster.

In contrast to the patients with the Croatian deletion, B-thal heterozygotes for the SEA deletion exhibit markedly higher $H \mathrm{~b} F(17.6-26.6 \%)$ and modestly elevated $\mathrm{Hb} \mathrm{A}_{2}$ levels $(2.7-5.1 \%)$. The $5^{\prime}$ breakpoint of this deletion is in the vicinity of the $5^{\prime}$ breakpoint of the Croatian deletion, but the $3^{\prime}$ breakpoint is located further downstream because the entire B-giobin gene and about $24 \mathrm{~kb}$ of the $3^{\prime}$ flanking sequence, including the $3^{\prime} \mathrm{HS}-1$, are part of the deletion. Analyses of the $5^{\prime}$ LCR HS-2 and the $G_{\gamma}$ and $A_{\gamma}$ gene promoter regions reveal that the two chromosomes carrying the Croatian or the SEA deletion have the same sequence variations in this region, i.e. the $C \rightarrow r$ substitution at -158 in the $G_{Y}$ promoter and the haplotype \#3-1ike motif in the LCR $5^{\prime}$ HS-2. This suggests that the different phenotypes are likely the result of the differences in the $3^{\prime}$ breakpoint. Indeed, the $3^{\prime}$ breakpoints of four other deletions associated with markedly increased $\mathrm{Hb} F$, namely the Indian and Italian HPFH and the German and Belgian $G_{Y}\left({ }^{A}{ }_{\gamma} \delta\right)^{\circ}$ thalassemias, are clustered in this vicinity (23) (Fig. $4 \mathrm{c} / 2$ ). It was proposed that the enhancer-like sequences located $3^{\prime}$ to the breakpoint of these deletions are capable of up-regulating the $\gamma$-globin gene sequences when trans-located into the vicinity of the $\gamma$ genes (24). This possibility is attractive for the deletions which include the $\delta$-globin gene, quite different from the observation for the chromosome with the SEA deletion because the $\delta$-globin gene remains intact. Thus, a juxtaposed enhancer would be closer to the $\delta$ gene on this chromosome and would exert its higher expression on this gene rather than on the $r$ genes.

Since this has not been observed, a more plausible explanation is that the $3^{\prime}$ HS-1 sequences have a role in the silencing of the $r$ genes in adult erythropoietic cells. The loss of the latter would leave the control of the B-globin gene cluster expression solely to the $5^{\prime}$ LCR sequences. The regulatory effect of these sequences on the individual genes is influenced by proximity (25) and thus, the closer $r$ genes are expressed preferentially over the $\delta$-globin genes. The presence of specific sequence variations in 
the $5^{\prime}$ HS-2 and the $G_{Y}$ promoter regions further facilitates this interaction. Recent findings in transgenic mice experiments support this hypothesis, since the addition of $3^{\prime}$ HS-1 sequences facilitate the down-regulation of $5^{\prime}$ LCR- $Y$ constructs in adult erythroid tissues (26).

\section{CONCLUSIONS}

From the results described in this dissertation it appears that the specific sequence variations in the LCR $5^{\prime}$ HS-2 together with the C $\rightarrow T$ substitution in the $G_{Y}$ promoter region are at least in part responsible for the elevated levels of $\mathrm{Hb} \mathrm{F}$ in SS and B-thal patients. The low Hb F levels in SS patients with haplotype \#19 are most probably due to the modified sequence of the $5^{\prime} \mathrm{HS}-2$, whereas the reasons for the low levels of $\mathrm{Hb} F$ in SS patients with haplotypes \#20 and \#17 are yet to be determined. The possible influence of sequence variations observed in the $G_{\gamma}$ and $A_{Y} 5^{\prime}$ flanking

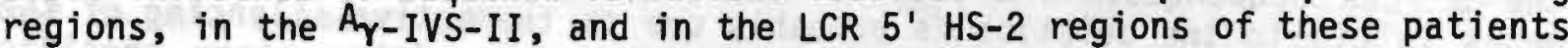
on the overall expression of $\boldsymbol{\gamma}$-globin genes could be tested in an experimental system where the conditions of hematopoietic stress are reproduced, e.g. transgenic mice. The data obtained for the patients with the SEA deletion are probably the most exciting of the results included here. The effect of the (deletion of) the LCR $3^{\prime}$ HS-1 segment on the activity of the $\gamma$-globin genes is a new observation which might be of basic importance for the concept of gene regulation. Indeed, the silencing effect of this segment of DNA should be evaluated further through studies of patients with additional deletions or mutations within this sequence, and by in vitro experimentation.

\section{REFERENCES}

1. Savagner, P., Miyashita, T., and Yamada, Y.: Two silencers regulate the tissue-specific expression of the collagen II gene. J.Biol. Chem., 265:669, 1990.

2. Devlin, B.H., Wefald, F.C., Kraus, W.E., Bernard, T.S., and Williams, R.S.: Identification of a muscle-specific enhancer within the $5 i$ flanking region of the human myoglobin gene. J. Biol. Chem., 264: $13896,1989$.

3. Gillies, S.D., Morrison, S.L., 0i, V.T., and Tonegawa, S.: A tissue specific transcription enhancer element is located in the major intron as a rearranged immunoglobul in heavy chain gene. Cell 33:717, 1983.

4. Collis, P., Antoniou, M., and Grosveld, F.: Definition of the minimal requirements within the human $\beta-g l o b i n$ gene and dominant control region for high level expression. EMBO J., 9:23, 1990.

5. Enver, T., Raich, N., Ebens, A.J., Papayannopoulou, Th., Constantini, F., and Stamatoyannopoulos, G.: Developmental regulation of human fetal to adult globin gene switching in transgenic mice. Nature, 344 : $309,1990$.

6. Boehringer, R.R., Ryan, T.M., Palmiter, R.D., Brinster, R.L., and Townes, T.M.: Human $\gamma$ - to $\beta-g$ lobin gene switching in transgenic mice. 
7. Ottolenghi, S., Mantovani, R., Nicolis, S., Ronchi, A., and Giglioni, B.: DNA sequences regulating human globin gene transcription in nondeletional hereditary persistence of fetal hemoglobin. Hemoglobin, 13:523, 1989.

8. Talbot, D., Philipsen, S., Fraser, P., and Grosveld, F.: Detailed analysis of the site 3 region of the human $\beta-g l o b i n$ dominant control region. EMBO J., 9:2169, 1990.

9. Slightom, J.L., Blechl, A.E., and Smithies, O.: Human fetal $G_{\boldsymbol{\gamma}}$ and $A_{\boldsymbol{\gamma}}$ globin genes: Complete nucleotide sequences suggest that DNA can be exchanged between these duplicated genes. Cell, 21:627, 1980.

10. Stoeckert, C.J., Jr., Collins, F.S., and Weissman, S.M.: Human fetal globin DNA sequences suggest novel conversion event. Nucleic Acids Res., 12:4469, 1984.

11. Gilman, J.G. and Huisman, T.H.J.: DNA sequence variation associated with elevated fetal $G_{Y}$ globin production. Blood, $66: 783,1985$.

12. Labie, D., Dunda-Belkhodja, O., Rouabhi, F. Pagnier, J., Ragusa, A., and Nage1, R.L.: The -158 site $5^{\prime}$ to the $G_{\gamma}$ gene and $G_{\gamma}^{\prime}$ expression. Blood, $66: 1463,1985$.

13. Labie, D., Pagnier, J., Lapoumeroulie, C., Rouabhi, F., Dunda-Belkhodja, O., Chardin, P., Beldjord, C., Wajcman, H., Fabry, M.E., and Nagel, R.L.: Common haplotype dependency of high $G_{\gamma}$ globin gene expression and high $\mathrm{Hb} F$ levels in $\beta$-thalassemia and sickle cell anemia patients. Proc. Natl. Acad. Sci. USA, 82:2111, 1985.

14. Gilman, J.G.: Expression of $G_{\gamma}$ and $A_{\gamma}$ globin genes in human adults. Hemoglobin, 12:707, 1988.

15. Efremov, G.D., Gjorgovski, I., Stojanovski, N., Diaz-Chico, J.C., Harano, T., Kutlar, F., and Huisman, T.H.J.: One haplotype is associated with the Swiss type of hereditary persistence of fetal hemoglobin in the Yugoslavian population. Hum. Genet., 77:132, 1987.

16. Gilman, J.G.: Putative repressor protein from human and mouse cells binds between GATA-1 and CACCC sites of human $\gamma$ globin promoter. Blood, 80:3a (Suppl. 1), 1992.

17. Ragusa, A., Lapoumeroulie, C., Lombardo, M., Elion, J., Labie, D., and Krishnamoorthy, R.: Differential binding of nuclear protein factors to the polymorphic $A_{\text {YIVS2 (TG) repeat region and its relevance }}$ to $H b F$ response in stress anemia. Blood, 80:310a (Suppl. 1), 1992.

18. Walters, M. and Martin, D.I.: Functional erythroid promoters created by interaction of the transcription factor GATA-1 with CACCC and AP-1/ NFE-2 elements. Proc. Nat1. Acad. Sci. USA, 79:10444, 1992.

19. Berg, P.E., Williams, D.M., Qian, R.L., Cohen, R.B., Cao, S.X., Mittelman, M., and Schechter, A.N.: A cormon protein binds to two silencers $5^{\prime}$ to the human $\beta$-globin gene. Nucleic Acids Res., 17:8833, 1989.

20. Lavelle, D., Ducksworth, J., Gomes, G., Keller, M., Heller, P., and Desimone, J.: A homeodomain protein binds to rglobin gene regulatory sequences. Proc. Nat1. Acad. Sci. USA, 88:7317, 1991.

21. Adekile, A.D., Kitundu, M.N., Gu, L-H., Adeodu, 0.0., Lanclos, K.D., and Huisman, T.H.J.: Haplotypes in SS patients from Nigeria; characterization of one atypical $\beta^{S}$ haplotype \#19 (Benin) associated with elevated Hb F and high $G_{Y}$ levels. Ann. Hematol., 65:41, 1992.

22. Tuan, D., Solomon, W., Li, Q., and London, I.M.: The $B-1$ ike globin gene domain in erythroid cells. Proc. Nat1. Acad. Sci. USA, 82:6384, 1985 . 
23. Baysal, E.: $\delta \beta$-Thalassemia and HPFH Repository. Hemoglobin, in press.

24. Anagnou, N.P., Perez-Stable, C., Gelinas, R., Constantini, F., Liapaki, K., Constantopolou, M., Costeas, T., Moschonas, N., and Stamatoyannopoulous, G.: Sequences located $3^{\prime}$ to the breakpoint of HPFH-3 can modify the developmental expression of the ${ }^{A_{Y}}$ gene. Clin. Res., 38: $301 A, 1990$.

25. Hanscombe, 0., Whyatt, D., Fraser, P., Yannoutsos, N., Greaves, D., and Grosveld, F.: Importance of globin gene order for correct developmental expression. Genes Develop., 5:1387, 1991.

26. Dillon, N. and Grosveld, F.: Human $y$ globin genes silenced independently of other genes in the $\beta-g l o b i n$ locus. Nature, 350:252, 1991. 


\section{SUMARY}

The main objective of this thesis is to evaluate the factors involved in the determination of the Hb F levels in patients with SS and $B$-thal, with special emphasis on sequence variations in the regulatory regions of the $\beta-g l o b i n$ genes cluster.

A review of the literature on this subject is given in Chapter 1 and includes a description of the structure and function of human Hbs, the structure of the globin genes and their organization, and the regulation of the developmental expression of these genes. It is emphasized that the selective expression of the individual genes during ontogenesis is regulated at the level of transcription by: a) local control sequences (promoters, enhancers, and silencers) and distant (LCR) cis-acting control sequences, and b) trans-acting regulatory proteins which bind to the regulatory sequences. The chapter also provides a short description of the pathophysiology and clinical aspects of sickle cell anemia with special emphasis on variations of clinical severity in relation to the $H b F$ levels. These levels are influenced by the age of the individual, gender, co-existing chain deficiency, and by the chromosomal background (e.g. haplotypes) on which the ${ }_{\beta} S$ mutation is present. When reviewing the $B$-thalassemias it is emphasized that the evaluation of $\mathrm{Hb} F$ production in homozygous patients with severe disease is difficult because these patients receive regular blood transfusions from early childhood. Patients presenting with B-thalassemia intermedia provide a better opportunity of evaluating the overall $\boldsymbol{\gamma}$ chain synthesis. A possible relationship between certain variations in chromosomal background and elevated $H \mathrm{~b} F$ levels in these patients, as well as known sequence variations in the regulatory regions of the B-globin gene cluster which could be responsible for this phenomenon are reviewed.

Techniques used in this study are described in Chapter 2, and a synopsis of the patients is provided.

Chapter 3 concerns the analysis of variations of the $\mathrm{Hb} F$ levels in numerous SS patients relevant to the sequence variations in the regulatory region of the $B-g l o b i n$ gene cluster.

Chapter $3 a$ provides data from the sequence analysis of the $5^{\prime}$ flanking and IVS-II regions of both the $G_{\gamma}$ and $A_{r}$ globin genes of the SS patients with homozygosities for five different haplotypes. Comparison with previously published sequences for the normal chromosomes A and B show many similarities to chromosome B for haplotypes $\# 19$, $\# 20$, and $\# 17$, while haplotypes \#3 and \#31 are remarkably similar to chromosome $A$ and also similar to each other. Several unique mutations were found in the 5 ' flanking regions ( $G_{\gamma}$ and $A_{\gamma}$ ) and in the IVS-II segments of the same genes of haplotypes $\# 19, \# 20$, and \#17; the IVS-II segments of haplotypes $\# 3$ and \#31 were 
identical to those of chromosome A. The two general patterns that have been observed among the five haplotypes have most probably arisen by gene conversion events between the $A$ and $B$ type chromosomes in the African population. These patterns correlate with high and low Hb F expression, and it is speculated that these and other yet unknown gene conversions may contribute to the variation in $H b F$ and $G_{Y}$ levels observed among SS patients.

Chapter $3 b$ deals with the distribution of some specific sequence differences in the $5^{\prime}$ flanking regions of the $G_{\gamma-}$ and $A_{\gamma-g l o b i n}$ genes from numerous SS patients from the Southeastern United States, and from individuals with $A S, S-\beta-t h a 1, S C, A C, A-B-t h a 1$, and $A A$, whose haplotypes have previously been determined by restriction endonuclease mapping. All 134 chromosomes with haplotype \#19 were positive for the 6->T substitution at position $-657\left(A_{Y}\right)$, while 132 were also positive for the $C->6$ mutation at $-369\left(G_{\gamma}\right)$. The three specific changes for the chromosome with haplotype \#20 were found on all 54 chromosomes with this haplotype. The C->T mutation at $-1585^{\prime}$ to $G_{Y}$ was present on all 41 chromosomes with haplotype 43, and on two chromosomes with a related atypical haplotype. Normal and B-thal chromosomes with each of these substitutions had the same $5^{\prime}$ subhaplotype as $\beta$ S haplotypes $\# 19$ or $\# 20$, respectively. The close relationship between the occurrence of specific mutations and haplotype of $B S$ was used for a fast and reliable strategy to determine these haplotypes with specific oligonucleotide probes.

In Chapter 3c, the ${ }_{B} S$ haplotypes in 709 patients with SS disease, 30 with SC disease, 91 with S- $\beta$-thal, and in $322 \mathrm{Hb} \mathrm{S}$ heterozygotes from 14 different countries, were determined using the methodology described above. The results support previously published data obtained with conventional methodology, indicating that the ${ }_{\beta} S$ gene arose separately in different locations. The collaboration of numerous colleagues from around the world is gratefully acknowledged.

In Chapter 3d the sequence of the 5'HS-2 of the LCR from an SS patient homozygous for haplotype \#19 and with low levels of Hb F was compared to the same sequence from an SS patient homozygous for haplotype \#3 and with high levels of Hb F. Three single nt substitutions and a variable AT repeated sequence were present in the $5^{\prime} \mathrm{HS}-2$ of the haplotype \#19 individual. All SS patients with haplotype \#19 had these variations. The 5 'HS-2 sequence from an SS patient who is homozygous for haplotype \#19 but with abnormally high levels of Hb $F(>20 \%)$ was also examined. A crossover that has placed sequences similar to the $5^{\prime} \mathrm{HS}-2$ of haplotype \#3 in juxtaposition to the $5^{\prime}$ flanking regions of haplotype \#19 was observed. Thus, a $\beta^{S}$ chromosome with haplotype \#19 but having a 5 'HS-2 (LCR) characteristic for haplotype \#3 is associated with high $\gamma$ chain expression. It is postulated that factors produced under condition of hematopoietic stress, together with genetic determinants on the haplotype \#3-1ike LCR sequences allow for high level expression of $\gamma$-globin genes.

In Chapter 3e data from sequence analysis of the LCR $5^{\prime}$ HS-2, HS-3, and HS-4 from the ${ }^{S}$ chromosomes for five major haplotypes (\#19, \#20, \#3, \#31, and \#17) are presented. Haplotype specific sequence variations were found only in $5^{\prime}$ HS-2. These involved the two AT repeats located between 
positions -10623 and -10570 relative to the Cap site of the $\varepsilon-g$ lobin gene, where different patterns were found in all haplotypes.

Chapter 4 deals with the $H \mathrm{Hb} F$ levels in patients with $B$-thal. In Chapter 4a, sequence analysis of the $5^{\prime} \mathrm{HS}-2$ (LCR) and the promoter regions for the two $r$ globin genes of a Black patient with mild $B$-thalassemia major due to a C->T mutation at position -88 of the $B$ promoter and with high Hb $F$ levels is presented. Sequence variations in the $5^{\prime} H S-2$ were the same as observed for the $\beta^{S}$ chromosome with haplotype $\# 3$, while most of the $G_{\gamma}$ and $A_{Y}$ promoters had sequences similar to those of the $B^{S}$ chromosome with haplotype \#19. This atypical haplotype is apparently associated with an increased $Y$ chain production which is particularly evident during periods of severe hematopoietic stress. Additional analysis of several $B$-thal homozygotes with either the $C \rightarrow T$ mutation at -88 or the $A->6$ mutation at -29 , confirm the possible importance of the sequence differences in the 5'HS-2, and also suggest that at least two additional factors, namely a C->T mutation at position -158 of the $G_{Y}$ promoter and a relative deficiency in a chain synthesis, play a (perhaps less important) role in the increased Hb $F$ synthesis in these patients.

In Chapters $4 b$ and $4 c$ two new deletions associated with $B^{\circ}$-thal are described, namely the Croatian 1605 bp and $\sim 27$ kb SEA deletions. Heterozygotes for these deletions presented with a mild hypochromia and microcytosis; however, there were striking differences in the $\mathrm{Hb} \mathrm{A}_{2}$ and $\mathrm{Hb} \mathrm{F}$ levels ( $\mathrm{Hb} \mathrm{A}_{2} 8.2 \%$ and $\mathrm{Hb} F 8.5 \%$ in the Croatian, and $4 \% \mathrm{Hb} \mathrm{A}_{2}$ and $26 \% \mathrm{Hb} \mathrm{F}$ in the SEA deletion). Almost similar $5^{\prime}$ breakpoints have been observed in both deletions, whereas the $3^{\prime}$ breakpoints were quite different. The $3^{\prime}$ breakpoint of the SEA deletion includes the $3^{\prime} H S-1$ and it is hypothesized that removal of this region results in the loss of its rglobin gene silencing effect, which causes a markedly elevated $\mathrm{Hb} F$ with modest increase in $\mathrm{Hb} \mathrm{A}_{2}$ levels, unlike the situation in the Croatian deletion.

In Chapter 4d, sequence analysis of the $5^{\prime} \beta$-globin gene region has been carried out for numerous homozygous $\beta$-thal patients with different mutations, and of various ethnic backgrounds, in order to evaluate a possible influence of this region on the $\mathrm{Hb} F$ levels in these patients. Numerous patterns in the $(A T)_{X}(T)_{Y}$ motif have been observed which were specific for particular chromosomal haplotypes. No direct association between any of the $(A T)_{X}(T)_{Y}$ arrangements and an increased $\gamma$ gene expression ( ${ }^{G} Y$ and $H b F)$ levels could be demonstrated, suggesting that variations in the $(A T)_{X}(T)_{Y}$ motif are common polymorphisms.

Chapter $4 \mathrm{e}$ presents a review of the $H \mathrm{Hb} F$ and $Y$ composition data for heterozygotes with $\delta-, \beta_{-}$, and $\delta \beta_{-}$-thal who have an $A_{\gamma} T^{\top}$ mutation in cis or in trans. The results show that a deletion affecting adult $B$ genes favor the expression of $\gamma$ genes in $\mathrm{cis}$, while the deletion of a single $\gamma$ gene does not affect the expression of the $B$ gene in cis but leads to a faster postnatal $\gamma^{->\beta}$ switch. This information is consistent with the suggestion that $\gamma$ and $\beta$ genes are competing for activation by a common enhancer element, likely located in the LCR sequences. 
From the results described in this dissertation it appears that the specific sequence variations in the LCR $5^{\prime} H S-2$, together with the $C->T$ substitution in the $G_{Y}$ promoter region, are at least partly responsible for the elevated levels of $\mathrm{Hb} F$ in SS and $\beta$-thal patients. The low $\mathrm{Hb} F$ levels in SS patients with haplotype $\$ 19$ are most probably due to the modified sequence of the $5^{\prime} H S-2$, whereas the reasons for the low levels of Hb F in SS patients with haplotypes $\# 20$ and $\# 17$ are yet to be determined. The possible influence of sequence variations observed in the $G_{\boldsymbol{\gamma}}$ and $A_{\boldsymbol{\gamma}}$

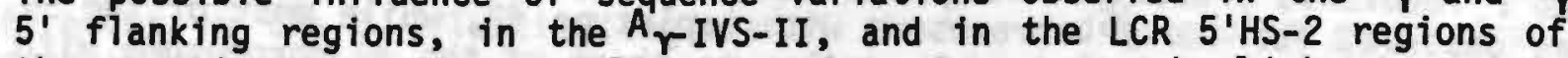
these patients on the overall expression of $\gamma$ genes should be tested in an experimental system where the conditions of hematopoietic stress are reproduced, e.g. transgenic mice. The observation made for the patients with the SEA deletion is probably the most significant information included in this dissertation. The effect of (deletion of) the LCR 3'HS-1 segment on the activity of the $\gamma$-globin genes is a new observation which might be of basic importance for the concept of gene regulation. Indeed, the silencing effect of this segment of DNA should be evaluated further through studies of patients with additional deletions or mutations within this sequence, and by in vitro experimentation. 


\section{Samenvatting}

Het in dit proefschrift beschreven onderzoek betreft het evalueren van factoren die bepalend zijn voor de concentratie van $\mathrm{HbF}$ in bloed van patiēnten met SS en Bthalassaemie, met speciale aandacht voor variaties in de DNA sequentie verschillen in genen die de expressie van het B-globine cluster reguleren.

In hoofdstuk 1 wordt een overzicht gegeven van de literatuur over dit onderwerp; hierin wordt tevens aandacht besteed aan een beschrijving van de structuur on functie van $\mathrm{HbS}$, de structuur van de globine genen en hun organisatie en aan de regulatie van de ontwikkelingsafhankelijke expressie van deze genen. Benadrukt wordt dat de selectieve expressie van de individuele genen gedurende de ontogenese gereguleerd wordt op transcriptie niveau door: a) lokale controle sequenties (promotors, enhancers en silencers) en verdenweg gelegen (LCR) cis-werkende controle sequenties, en b) trans-werkende regulerende eiwitten welke binden aan de regulerende sequenties. Ook worden in het kort de pathofysiologie en de klinische aspecten van sikkelcel anemie beschreven met speciale aandacht voor variaties in de klinische presentatie in relatie tot $\mathrm{HbF}$ waarden. Deze niveaus worden beīnvloed door leeftijd van de patiēnt, 'gender', eventuele $\alpha$-keten deficienties en door de chromosomale achtergrond (b.v. haplotypen) waarin de $B^{\text {s }}$ mutatie zich voordoet. Als alle B-thalassaemieēn worden beschouwd, dan wordt duidelijk dat evaluatie van de HbF-produktie in homozygote ernstig zieke patiënten moeilijk is, omdat deze patiënten regelmatig, vanaf de kindentijd, bloedtransfusies krijgen. Patiënten met een intermediaire B-thalassamie bieden een betere mogelijkheid om de $\gamma$-keten synthese te evalueren. Er wordt een mogelijke relatie besproken die zou bestaan tussen bepaalde variaties in de chromosomale achtergrond en de geēvalueerde $\mathrm{HbF}$ waarden in deze patiēnten, alsook een mogelijke relatie met bekende volgorde varianten in de regulerende genen van het $\gamma$-globine genen cluster, welke verantwoordelijk voor dit fenomeen zouden kunnen zijn.

Hoofdstuk 2 handelt over de technieken die toegepast zijn in deze studie, en bespreekt de patiënten die bij dit onderzoek zijn betrokken.

Hoofdstuk 3 behandelt de analyse van de variaties in HbF niveaus bij een groot aantal SS patienten, in relatie tot volgorde variaties in de regulerende sequenties van het B-globine genen cluster.

Hoofdstuk $3 a$ beschrijft de sequenties van de $5^{\prime}$ flankerende- en IVS-II regionen van zowel de G $\gamma$ - als de Ay-globine genen van SS patiënten, die homozygoot zijn voor vijf verschillende haplotypes. Vergelijking met eerder gepubliceerde sequenties van de normale chromosomen $A$ en $B$ laat een grote overeenkomst zien voor chromosoom B m.b.t. de haplotypes \#19, \#20, en \#17, terwijl de haplotypes \#3 en \#31 opvallende overeenkomst vertonen met chromosoom A en met elkaar. Verschillende unieke mutaties werden gevonden in de 5'-regio (Gy en $A y$ ) en in de IVS- 
II segmenten van dezelfde genen met haplotypes $\# 19$, \#20, en $\# 17$; de IVS-II segmenten van haplotypes \#3 en \#31 waren identiek voor die van chromosoom A De twee algemene patronen die werden waargenomen bij de 5 haplotypes zijn hoogstwaarschijnlijk ontstaan door gen overdracht tussen A en B type chromosomen in de Afrikaanse populatie. Deze patronen correleren met hoge en lage $\mathrm{HbF}$ expressie, en er wordt gespeculeerd of deze en mogelijk andere gen overdracht gebeurtenissen bijdragen aan de variatie in HbF- en Gy-niveaus bij SS patiēnten.

Hoofdstuk 3b gaat over de distributie van sommige specifieke volgorde verschillen in de 5'-flankerende regio's van de Gy- en de Ay-globine genen van een groot aantal SS patiēnten uit het zuid-oosten van de USA, en van individuen met AS-, SB-thalassemie, SC-, AC-, A-B-thalassemie en AA, waarvan de haplotypes eerder bepaald werden met behulp van restrictie fragment analyse. Alle 134 chromosomen met haplotype \#19 vertoonden de $G \rightarrow T$ substitutie op positie -657 (Ay), terwijl 132 eveneens een $C \rightarrow G$ substitutie hadden op positie -369 (Gy). De drie specifieke veranderingen voor het chromosoom met haplotype \#20 werden gevonden op alle 54 chromosomen met dat specifieke haplotype. De $C->T$ mutatie op plaats $-1585^{\prime}$ van Gy was aanwezig op alle 41 chromosomen met het haplotype \#3, en op de twee chromosomen met het gerelateerde atypische haplotype. Normale en B-thalassaemie chromosomen met een van deze substituties hadden hetzelfde 5 '-subhaplotype als resp. de $B^{\mathrm{S}}$ haplotypes $\# 19$ of $\# 20$. De nauwe relatie tussen het voorkomen van specifieke mutaties en haplotype $B^{S}$ werd gebruikt voor een snelle en betrouwbare strategie om deze haplotypes te bepalen met specifieke oligonucleotide probes.

In hoofdstuk $3 c$ werden de $B^{S}$ haplotypes in 709 patiēnten met SS-ziekte, 30 met SC-ziekte, 91 met S-B-thalassaemie en $322 \mathrm{HbS}$ heterozygoten uit 14 verschillende landen bepaald met de methodiek zoals hierboven beschreven. De resultaten ondersteunen eerder gepubliceerde gegevens, verkregen met conventionele methodes, die or op wijzen dat het $B^{\mathbf{S}}$ gen onafhankelijk ontstond c.q. werd gevonden op verschillende lokaties. De samenwerking met een groot aantal collega's uit alle windstreken wordt hier met erkentelijkheid vermeld.

In hoofdstuk 3d wordt een vergelijking gemaakt tussen sequenties van de 5'HS-2 van de LCR van een SS patiênt die homozygoot is voor het haplotype \#19 en een lage $\mathrm{HbF}$ concentratie heeft, en dezelfde volgorde van een SS patiënt die homozygoot is voor het haplotype \#3, maar met een hoge HbF concentratie. Drie enkele nucleotide substituties en een variabele AT repeat volgorde waren aanwezig in het 5'HS-2 van het individu met haplotype \#19. Alle SS patiēnten met het haplotype \#19 hadden deze variaties. De 5'HS-2 sequentie van een SS patiēnt homozygoot voor het haplotype \#19, maar met een abnormaal hoog HbF gehalte $(>20 \%)$ werd ook onderzocht. Klaarblijkelijk heeft een cross-over geresulteerd in het naast elkaar plaatsen van sequenties die gelijk waren aan het 5'HS-2 van haplotype \#3 en de 54 lankerende volgorde van het haplotype \#19. Een $B^{S}$ chromosoom met haplotype \#19 maar met een 5'HS-2 (LCR) karakteristiek voor haplotype \#3 is blijkbaar 
geassocieerd met een hoge $\gamma$-keten expressie. Er wordt gepostuleerd dat factoren die geproduceerd worden in een situatie van haematopoietische stress, samen met genetische determinanten op haplotype \#3-achtige LCR volgordes leiden tot een hoge expressie van de $y$-globine genen.

Hoofdstuk $3 e$ presenteert sequentie analyses van de LCR $5^{\prime}$ HS-2, HS-3 en HS-4 van de $B^{S}$ chromosomen van de vijf verschillende haplotypes $(\# 19, \# 20, \# 3, \# 31$ en \#17). Haplotype specifieke sequentie variaties werden alleen gevonden in $5^{\prime} \mathrm{HS}-2$. Deze betroffen de twee AT-repeats, gelokaliseerd tussen posities -10623 en 10570, gerelateerd aan de Cap site van het $\varepsilon$-globine gen, waar verschillende patronen werden gevonden bij alle haplotypes.

In hoofdstuk 4 wordt het onderzoek naar HbF waarden bij patiẽnten met $\mathrm{B}$-thalassaemie beschreven.

In hoofdstuk 4a worden sequentie analyses gepresenteerd van de 5'HS-2 (LCR) en de promotor regio's van de twee -globine genen van een negerpatiënt met een milde vorm van B-thalassaemie t.g.v. een $C \rightarrow T$ mutatie op positie -88 van de B-globine promotor en met een hoge HbF. Volgorde variaties in het 5'HS-2 waren dezelfde als die waargenomen in het $B^{S}$ chromosoom met haplotype \#3, terwijl het grootste deel van de $\mathrm{G}_{\gamma}$ en Ay promotorsequenties gelijk waren aan die van het $B^{S}$ chromosoom met haplotype \#19. Dit atypische haplotype is blijkbaar geassocieerd met een toegenomen $\gamma$-keten produktie, welke in het bijzonder tot uiting komt in gevallen van ernstige haematopoietische stress. Additionele analyse van verschillende homozygote B-thalassaemieên met, òf de C --> T mutatie op positie -88 df de A $\rightarrow$ G mutatie op positie -29 , bevestigde het mogelijke belang van de volgorde verschillen in de $5^{\prime} \mathrm{HS}-2$ regio. Daarbij zouden tenminste nog twee additionele factoren, namelijk een $C->T$ mutatie op positie -158 van de ${ }^{G} y$-promotor en een relatieve deficiēntie in de $\alpha$-keten synthese, een (mogelijk minder belangrijke) rol kunnen spelen bij de toegenomen HbF synthese in de patiēnten.

In de hoofdstukken $\mathbf{4 b}$ en $\mathbf{4 c}$ worden twee nieuwe met $\mathrm{B}^{\circ}$-thalassaemie geassocieerde deleties beschreven, $\mathrm{nl}$. de kroatische $1605 \mathrm{bp}$ - en een circa $27 \mathrm{~kb}$ SEA deletie. Heterozygoten voor deze deleties hadden licht-hypochrome en microcytaire erythrocyten; wel was er een opvallend verschil tussen de $\mathrm{HbA}_{2}$ en de $\mathrm{HbF}$ gehaltes ( $\mathrm{HbA}_{2} 8,2 \%$ en $\mathrm{HbF} 8,5 \%$ in het geval van de kroatische deletie, en $\mathrm{HbA}_{2} 4,2 \%$ en HbF $26 \%$ in het geval van de SEA deletie). In beide deleties werden bijna gelijke $5^{\prime}-$ breukpunten waargenomen, terwijl de 3'-breukpunten zeer verschillend waren. Het 3'-breukpunt van de SEA deletie bevatte de 3'HS-1 regio. De hypothese is dat het ontbreken van dit DNA stuk resulteert in het verlies van het 'silencing' effect van het y-globine gen, zodat een aanmerkelijk toegenomen HbF expressie het gevolg is, met een middelmatige $\mathrm{HbA}_{2}$ toename, dit in tegenstelling tot de situatie bij de kroatische deletie.

Hoofdstuk 4d. Sequentie analyse van de 5' B-globine regio is uitgevoerd bij vele 
homozygote B-thalassaemiepatiēnten, met verschillende mutaties en variērende ethnische herkomst, om de mogelijke invloed van deze regio op de HbF concentraties na te gaan. In het $\left((A)_{x}(T)_{y}\right.$ motief werden talrijke patronen gevonden die specifiek zijn voor bijzondere chromosomale haplotypen. Er kon geen direct verband aangetoond worden tussen enige $\left(A T_{x}(T)\right.$, rangschikking en een toegenomen $\gamma$ gen expressie $(\mathrm{g} g$ en $\mathrm{HbF})$; dit suggereert dat variaties in het $(A T)_{x}(T)_{y}$ motief opgevat moeten worden als een normaal polymorphisme.

In hoofdstuk 4e wordt een overzicht gegeven betreffende $\mathrm{HbF}$ en $\gamma$ compositie van heterozygoten met $\gamma$-, $\partial$ - en $\partial B$-thalassemie die een $\mathcal{\gamma}^{\top}$ mutatie in cis of in trans positie hebben. De resultaten laten zien dat een deletie betreffende volwassen $B$ genen, de expressie van cis $\gamma$-genen bevordert, terwijl de deletie van een enkel $\gamma$ gen de expressie van de B-genen niet beinvloedt, maar leidt tot een snellere postnatale $\gamma \Rightarrow B$ shift. Deze bevindingen passen bij de suggestie dat er een competitie bestaat voor de activatie van $\gamma$ - on B-genen ten aanzien van een gemeenschappelijk enhancer-element, dat waarschijnlijk gelokaliseerd is in de LCR sequenties.

Uit de in dit proefschrift beschreven onderzoeksresultaten blijkt dat specifieke sequentieverschillen in de LCR $5^{\prime}$ HS-2 regio, in combinatie met de $C \rightarrow$ T substitutie in het ${ }^{a} y$ promotor gebied, ten minste voor een deel verantwoordelijk zijn voor verhoogde concentraties $\mathrm{HbF}$ bij SS- en B-thalassaemie patienten. De lage $\mathrm{HbF}$ concentraties bij SS-patiēnten met haplotype \#19 zijn hoogst waarschijnlijk het gevolg van een afwijkende 5'HS-2 sequentie, terwijl de redenen voor de lage HbF concentraties bij SS-patiēnten met de haplotypes \#20 en \#17 nog niet zijn opgehelderd. De mogelijke invloed van de gevonden volgorde variaties in de ${ }^{6} \gamma$ en ${ }^{A} \gamma 5$ ' flankerende regio's, in de A $\gamma$-IVS-II en in de LCR 5'HS-2 regionen van deze patiēnten op de overall expressie van $y$-genen, moet nog onderzocht worden in een experimenteel systeem waar condities van haematopoietische stress gereproduceerd kunnen worden, b.v. in transgene muizen. De bevinding met betrekking tot de patiënten met de SEA deletie is mogelijk de belangrijkste informatie in dit proefschrift. Het effect van (deletie van) het LCR 3'HS-1 segment op de activiteit van de $\gamma$-globine genen is een nieuwe bevinding welke van fundamenteel belang kan zijn voor het concept van gen-regulatie. Het 'silencing' effect van dit DNA segment moet inderdaad nog verder onderzocht worden in in vivo studies met patiēnten met additionele deleties of mutaties in deze sequentie, en door middel van in vitro experimenten. 


\section{CURRICULUM VITAE}

Name:

Aleksandar Jovo DIMOVSKI

Date of Birth:

Sex:

October 18, 1962

Place of Birth:

Citizenship:

Male

Skopje, Republic of Macedonia

Macedonian

Education:

University

Graduated from the Faculty of Medicine at the of Kiril and Metodij, Skopje, Macedonia, in 1987 with an average grade of $9.5 / 10$.

Postdoctoral Training:

1989 -1990 (one year):

Department of Cell and Molecular Biology at the Medical College of Georgia in Augusta, GA, USA.

Research Experience:

Five years laboratory experience in Gene mapping, PCR amplification, dot blot hybridization, gene cloning, DNA sequencing, Northern blot analysis, etc.

Position:

Research Assistent, Macedonian Academy of Sciences and Arts, Research Center for New Technologies,

Skopje.

Republic of Macedonia.

Present Address:

School of Medicine,

Department of Biochemistry and Molecular Biology, Medical College of Georgia, Augusta, GA. 30912-2100 USA. 
